\author{
Universidade de São Paulo \\ Faculdade de Filosofia, Letras e Ciências Humanas \\ Departamento de Filosofia \\ Programa de pós-graduação em Filosofia
}

SILVIO GABRIEL SERRANO NUNES

Constitucionalismo e Resistência em Théodore de Bèze: Secularização e Universalidade do Direito de Resistir na obra

Du Droit des Magistrats sur leurs sujets de 1574

\author{
versão corrigida
}

São Paulo 
SILVIO GABRIEL SERRANO NUNES

\title{
Constitucionalismo e Resistência em Théodore de Bèze: Secularização e Universalidade do Direito de Resistir na obra \\ Du Droit des Magistrats sur leurs sujets de 1574
}

\author{
Dissertação de Mestrado apresentada \\ ao Departamento de Filosofia da \\ Universidade de São Paulo sob \\ orientação da Prof ${ }^{a}$. Dr ${ }^{a}$. Maria das \\ Graças de Souza.
}

versão corrigida

São Paulo 
Banca Examinadora

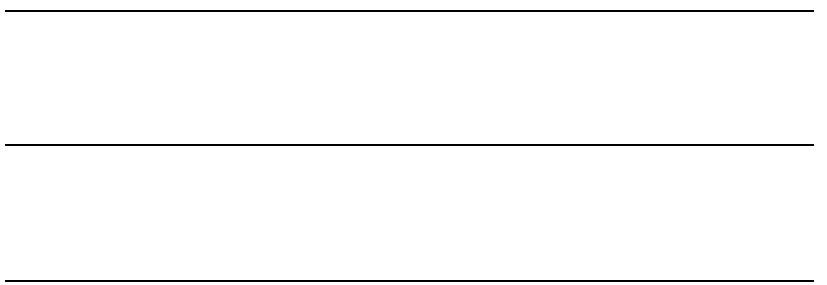


"E de fato vejamos se em todos os tempos e em todas as nações mais conhecidas, se isso não foi assim praticado."

Théodore de Bèze 
À memória das mulheres e homens, de mais de cinquenta nacionalidades, ao número de dezenas de milhares que, quando as sombras do Fascismo pareciam cobrir a Terra em aparente impunidade, levantaram-se em armas, recursos materiais e poesia, compondo um "espetáculo asombroso" e "magnífico", ao unirem-se a um povo e seus legítimos magistrados, abraçando a causa de uma virtuosa mulher-ainda-menina, a II República Espanhola, que em definitivo havia posto um povo livre de uma tirania e só possibilitou que outra se restabelecesse após o exaurimento completo de suas forças.

Mulheres e homens - entre anônimos e notórios como: André Malraux, Antoine de Saint - Exupéry, Apolônio de Carvalho, Betty Davis, Carlos Drummond de Andrade, Charles Chaplin, Charles Donnelly, Duquesa Katherine de Atholl, Erroll Flynn, Érico Veríssimo, Frida Kahlo, John dos Passos, George Orwell, Gerda Taro, Jorge Amado, Manuel Bandeira, Oliver Law, Pablo Neruda, Presidente da República Mexicana Lázaro Cárdenas del Río, Robert Capa, Salaria Kee Reilly, Simone Weil... “de distinto color, de ideología diferente, de religiones antagónicas, pero amando todos ellos profundamente la libertad y la justicia”, que ao se saudarem, com os punhos cerrados e em riste, nas mais diversas línguas com a expressão ¡¡Viva la Republica!! e seus respectivos valores, expressavam em larga medida ideais de vocação universal, como resistência e constitucionalismo, que tanto teriam agradado ao nosso autor.

Aos que partiram para o teatro de guerra, "sin ninguna obediencia a jerarquía superior" a não ser às suas próprias consciências para "defender la justicia e el derecho escarnecido", e nunca mais voltaram, tendo sido enterrados em valas comuns pelos vales e cercanias como as de Madri, Rio Ebro, Jarama, Brihuega, Lérida, Belchite, Guadalajara, Brunete, Teruel, Toledo, Levante, Alicante... sem condecorações, reconhecimento e muito menos a suntuosidade (paixão tão recorrente a tiranos) de um "Valle de los Caídos", que lhes sirvam de eterno monumento as palavras de um de vós: "No man ever entered the earth more honorably than those who died in Spain." (Ernest Hemingway).

Singela e humilde homenagem sobretudo direcionada aos cerca de quarenta brasileiros que para lá partiram por motivos óbvios; e aos oitocentos suíços que, apesar de ostentarem a nacionalidade de uma pátria cujas fronteiras também compreendiam a terra que testemunhara o florescer das ideias de Bèze, foram os componentes das Brigadas Internacionales mais severamente punidos por um regime democrático à 
época, ao retornarem de seus feitos heroícos, condenados inclusive criminalmente por participarem de um conflito armado estrangeiro.

* As expressões em itálico e castelhano na presente dedicatória são extraídas dos discursos da Deputada Dolores Ibárruri, La Pasionaria, e do Primeiro-Ministro Dr. Juan Negrín, proferidos por ocasião da retirada das Brigadas Internacionales, numa Catalonya ainda republicà, no dia 28 de outubro de 1938 em Barcelona, e 25 de outubro de 1938 em Les Masies, respectivamente.

Assim procedendo, objetivamos homenagear e rememorar todos os legítimos magistrados daquela república, ou equiparáveis face a uma tirania de origem (valemonos, na presente oportunidade, da ampla acepção que a palavra 'magistrado' possuía no século XVI), dentre os quais citamos: Presidente Niceto Alcalá Zamora; General José Miaja e seu estrategista Coronel Vicente Rojo; Coronel Defensor de Badajós Ildefonso Puigdendolas; General da Aviação Republicana Ignácio Hidalgo de Cisneros; Pres. da Junta Central do Tesouro Artístico Timoteo Pérez Rubio; Ministra de Estado Federica Monteseny; Ministro de Estado Manuel de Irujo; Pres. da Generalitat de Catalonya Lluis Companys i Jover; Primeiro Lehendakari José Antonio Aguirre y Lecube; PrimeiroMinistro Francisco Largo Caballero; Diplomatas Isabel de Palencia e Francisco de Ayala; Deputadas Margarita Nelken, Victoria Kent e Clara Campoamor; Deputado Luis Ricasens Siches; Presidente do Tribunal Supremo Mariano Gómez González; Máxima Autoridade republicana na agonia final do cerco de Madri Julián Besteiro; Organizadora do Comitê de Defesa de Mérida Anita López; Libertador de Mesas de Ibor Jerónimo Curiel...

e principalmente ao seu supremo magistrado: Exmo. Sr. Presidente da República Espanhola Manuel Díaz Azaña (Alcalá de Henares, Espanha, 10 de janeiro de 1880 Montauban, França, 3 de novembro de 1940), cujo apego à legalidade e esforços de conciliação, mesmo em circunstâncias tão adversas, mostrou-se antípoda perfeito de tirano.

12 de Março de 2009.

(Data da aprovação pelo Conseil des États, o senado helvético, da reabilitação dos voluntários suíços que compuseram as Brigadas Internacionales). 
Em agradecimento:

Aos meus pais, Célia e Sérgio, pela generosidade sem limites, sobretudo com os filhos.

À minha avó Wanda, pela força, em poucas palavras, mas com muito afeto, pois mais agiu nas adversidades ao longo da vida do que falou, respeitemos o exemplo...e à sua irmã tia Nilza, Professora Primária de Escola Pública Rural nos confins do estado de São Paulo, que durante minha infância sovava pães enquanto lia para mim histórias, contribuindo no meu processo de alfabetização. Além de alimentar minha imaginação e o sabor pela leitura, e que talvez, sob inspiração de minha história favorita "O novelo de Ariadne", tenha feito das linhas dos livros guia para os labirintos da vida e seus minotauros.

À professora Dra. Maria das Graças de Souza, pela oportunidade da convivência intelectual e afetiva, durante todo o período de orientação. Além dos anos de tanta aprendizagem e amizade, registramos o privilégio de ter sido sempre corrigido nos desvios de percurso com uma pequena e ao mesmo tempo grandiosa virtude, a polidez.

À Banca de nosso exame de qualificação, pelas contribuições bibliográficas, sugestões e correções - o que de forma alguma nos exime da integral responsabilidade pelos desacertos do presente trabalho - Prof ${ }^{\mathrm{a}}$. Dr ${ }^{\mathrm{a}}$. Maria Constança Peres Pissarra e Prof. Dr. Alberto Ribeiro Barros.

Ao único. Meu único irmão Sérgio e a sua esposa Renata, e principalmente ao pequeno Eduardo Vilalba Serrano Nunes, que trouxe consigo tantas alegrias.

Aos primos-irmãos Antônio Carlos Alves Pinto Serrano, (assim como aos seus irmãos: Pedro, Dal, Aninha, Yolanda e Carolina) e a Stella Sablone Serrano, entusiastas de primeira hora, cujo suporte incondicional em todas as etapas de elaboração do presente trabalho fez-se algo sem o qual, em hipótese nenhuma, teríamos conseguido concluir.

As minhas pequenas Nathália e Fernanda Anchieta Gabriel, que com graça e virtude também resistem em suas vidas, e aos nossos primos em comum, Stella, Mirella e Neto.

E por fim aos tios: Vidal, pelas polêmicas, Reginaldo, pelas gargalhadas, e ao Juninho, pelos 'causos'. 
Aos amigos da Faculdade de Filosofia (USP), Taynam Bueno, Thiago Brás, Kelly Koide, Ana Carolina Salgado, Leonardo, Bruno Boaro, Maria Rita, Pedro Ivo, Ana Gasonato... pelas horas de risos e pelo "concreto" apoio acadêmico, e aos amigos da Faculdade de Direito (PUC-SP), assim como os de ainda dos tempos do Colégio Agostiniano São José de São José do Rio Preto-SP, Thiago (inclusive a hospitalidade), João Marcelo, Vinícius, José Augusto, Marcelo, Fernando, Rubens e Roberto; apesar da diversidade dos caminhos trilhados, insistimos em sempre nos revermos.

À professora Dra. Lídia Reis de Almeida Prado, pelo estímulo ainda naqueles primeiros anos da faculdade de Direito, para que me aventurasse na Filosofia.

A Dra. Nayra Penha Cesaro Ganhito, pela escuta generosa e acolhimento em sua Berggasse 19, enquanto "fugia do gueto de minhas obsessões", para que leia tudo como imagem, quem sabe as de um postal de Genebra, terra que acolheu tantos exilados. À CAPES pelo apoio financeiro. 


\section{RESUMO}

A presente dissertação de mestrado tem por finalidade examinar a questão do direito político de resistência elaborado por Théodore de Bèze em seu tratado Du Droit des Magistrats, de 1574, apontando a influência das fontes seculares, católicas, e a forma peculiar como Bèze dialoga com outros reformadores precedentes (Lutero, Calvino e Müntzer).

Na análise da obra Du Droit des Magistrats, destacamos a recepção do argumento de resistência constitucional, preliminarmente elaborado pelos juristas da região de Hesse, por ocasião da crise vivida pelo luteranismo no raiar da década de 1530 , e em larga medida desenvolvido e ampliado por Bèze, que lhe confere tom de universalidade.

Por fim, apontaremos contribuições do pensamento político do reformador sucessor de Calvino em Genebra para os mecanismos de controle dos governantes na tradição do pensamento constitucionalista, como os que contemporaneamente denominamos de parlamentar e jurisdicional.

PALAVRAS-CHAVE: direito de resistência, constitucionalismo, Théodore de Bèze, secularização, Reforma 


\begin{abstract}
This study aims to analysis the political right of resistance developed by Théodore de Bèze in Du Droit des Magistrats, written on 1574, emphasizing the influence of secular and Catholic sources, and the particular way as Bèze communicates with another previous reformers (Lutero, Calvino e Müntzer).

In the analysis of Du Droit des Magistrats, it will be highlighted the receipt of the constitutional argument of resistance, preliminarly drafted by jurists from Hesse when the Lutheranism felt in crisis, at 1530 decade, specially developed and broadened by Bèze.

Finally, it will be pointed contributions from the political thought of the Reformer Calvino's sucessor in Geneva to the control mechanisms of the rulers in the tradition of constitutional thought, as the today considered parliamentary and judicial systems.
\end{abstract}

KEY-WORDS: right of resistance, constitucionalism, Théodore de Bèze, secularization, Reform 


\section{SUMÁRIO}

\section{CAPÍTULO I - A PRUDÊNCIA DOS "PAIS" DA REFORMA E O ARROJO DOS “FILHOS" NO QUE TANGE AO DIREITO POLÍTICO DE RESISTÊNCIA}

1.1. A exortação de Paulo aos romanos

1.2. A reforma protestante e seu patriarcado agostiniano

1.3. O quase nulo grau de adesão de Lutero ao direito de resistência

$1.4 \mathrm{O}$ argumento constitucional em Calvino a título de ambígua especulação

1.5 Müntzer e a "horda sanguinária dos salteadores"

1.6 A solidez de adesão de luteranos e calvinistas ao constitucionalismo

de resistência a partir de 1530

\section{CAPÍTULO II - AS FONTES MEDIEVAIS, CATÓLICAS E SECULARES PARA O CONSTITUCIONALISMO DE THÉODORE DE BÈZE E SUAS PRIMEIRAS INCURSÕES NO DEBATE POLÍTICO DO DIREITO DE RESISTENCIA}

2.1 A construção teórica escolástica de resistência à tirania

$2.2 \mathrm{O}$ recurso ao constrangedor argumento católico dos conciliaristas

2.3 A inspiração nos Direitos Seculares Feudal e Urbano

59

2.4 Um Importante Precedente: A Cidade de Magdeburgo e sua Confissão, de 1550, rememorada por Bèze em Da punição dos hereges pelo magistrado civil, de 1554

2.5 Uma primeira sistematização do pensamento político de resistência em Bèze:

Confession de la foi chrestienne, em 1560

\section{CAPÍTULO III - A PLENITUDE DO ARGUMENTO CONSTITUCIONAL EXPRESSO EM DU DROIT DES MAGISTRATS SUR LEURS SUJETS}

3.1 A supremacia do dever de obediência a Deus e não aos homens:

a reafirmação das teses dos luteranos de segunda geração

3.2 O duplo pacto em Théodore de Bèze: uma aliança entre Deus com o Príncipe

e seu povo e um contrato entre o Príncipe e o povo

3.3 Constitucionalismo, História e Secularização no debate sobre a vida civil

em Bèze no problema crucial do tratado: a Tirania Manifesta

3.4 As reações possíveis à Tirania Manifesta segundo as vocações dos particulares e dos graus de magistraturas

3.5 Os treze exemplos universalizantes do direito de resistência institucionalizado

3.6 Os objetos de tutela da proteção magisterial: "a liberdade de consciência religiosa", a propriedade e o regular funcionamento das instituições da República

CONSIDERAÇÕES FINAIS - O MAGISTRADO, A LEI E A REPÚBLICA

NO CALVINISMO CONSTITUCIONAL E O PONTO DE TOQUE ENTRE UM

DISCURSO CONTRATUAL E UM CONSTITUCIONALISMO

PROPRIAMENTE DITO 


\section{INTRODUÇÃO}

A presente dissertação de mestrado tem por finalidade examinar a questão do direito político de resistência elaborado por Théodore de Bèze em seu tratado Du Droit des Magistrats de 1574, apontando a influência das fontes seculares, católicas, e a forma peculiar como Bèze dialoga com outros reformadores precedentes (Lutero, Calvino e Müntzer).

Num primeiro capítulo, apresentaremos as linhas gerais do pensamento político gerado por reformadores imediatamente anteriores a Bèze e sua época, assim como seu diálogo com os escritos de Paulo e Agostinho, com o intuito de tecer o pano de fundo no qual germinam as teses de nosso autor, sobretudo demarcando os pontos distintos da clássica categorização feita por vários comentadores (Skinner, Höpfl, Willians, Collinson, entre outros) do movimento reformador como magisterial e radical, apontando principalmente o notório contraste entre uma prudência que comporta gradações no pensamento de Lutero e Calvino quanto à possibilidade do exercício do direito político de resistência, e um arrojo aferido nos escritos de luteranos e calvinistas, que apesar de reafirmarem o rechaço às teses dos reformadores radicais, apresentam uma elaboração teórica inequívoca e sólida de um pensamento justificador da licitude no combate às tiranias.

Ainda no capítulo 1, A prudência dos pais da reforma e o arrojo dos filhos no que

tange ao direito político de resistência, pretendemos adentrar propriamente nas fontes primárias desses pensadores. Nos itens 1.1 e 1.2, respectivamente, exporemos a problemática da exortação de Paulo aos romanos sobre o dever de obediência às autoridades constituídas, passagem bíblica central para as questões políticas discutidas por toda a Reforma Protestante, e os nortes agostinianos sobre a vida civil encontrados no pensamento reformado.

Nos itens 1.3, 1.4 e 1.5, pretende-se analisar os escritos de Lutero e Calvino, identificando suas condições de reformadores magisteriais com distintos graus de adesão às teses de resistência, como também contrastar tais escritos com os de Müntzer, que talvez componham o melhor paradigma das ideias propagadas pela Reforma Radical.

Para finalizar o capítulo I, mostraremos a mudança de paradigma proposto por luteranos e calvinistas a partir da década 1530, sinalizando sua diferença na fundamentação mais pautada na autoridade bíblica dos primeiros (ainda que tal fundamentação, em verdade, segundo Skinner, teria sua origem em uma readequação interpretativa da Bíblia, influenciada por argumentos seculares de resistência extraídos do Digesto e das leis fundamentais do Sacro Império Romano Germânico), e a fundamentação de calvinistas, que reafirmam os 
argumentos teológicos dos luteranos, porém desenvolvem amplamente a discussão da resistência num patamar mais secular.

No capítulo 2, As fontes medievais, católicas e seculares para o constitucionalismo de Théodore de Bèze, pretendemos esmiuçar as origens do pensamento de Bèze em suas raízes medievais seculares (como o direito feudal e o urbano), católicas (como o constrangedor recurso aos argumentos conciliaristas), além de apontar a importância, para nosso autor, do precedente prático e teórico do exercício de resistência política na cidade de Magdeburgo, e sua Confissão, de 1550, que já o cita em sua obra de 1554, Da punição dos hereges pelo magistrado civil, como também citar o primeiro esboço de sistematização de pensamento político, que Bèze faz em um dos tópicos de seu catecismo de 1560: Confession de la foi chrestienne.

Postos esses antecedentes teóricos e referenciais para o nosso autor, no capítulo 3, A plenitude do argumento constitucional expresso em Du Droit des Magistrats sur leus Sujets, adentraremos na análise da obra Du Droit des Magistrats sur leus Sujets de 1574, abordando as seguintes questões: a reafirmação das teses de origem bíblica autorizadoras do exercício lícito do direito de resistência elaborada por luteranos de segunda geração; o duplo pacto: uma Aliança entre Deus com o príncipe e seu povo, e um Contrato (propriamente dito) entre o príncipe e seu povo. No item 3.3, trataremos as relações entre: constitucionalismo, o recurso à história e suas repercussões na secularização do pensamento de Bèze sobre o problema crucial do tratado: a tirania manifesta. Nesse tópico, descreveremos o argumento constitucional elaborado pelo sucessor de Calvino em Genebra, pela via dos magistrados inferiores, assim como esmiuçaremos os treze exemplos históricos que comprovam o argumento, favorecendo a manutenção do debate num contexto secular e não confessional.

Abordaremos também questões que são objeto de tutela da proteção magisterial no exercício lícito da resistência: "a liberdade de consciência religiosa", a propriedade e o regular funcionamento das instituições de um governo de leis.

Nas Considerações Finais, pretende-se abordar as noções fundamentais da tradição republicana, magistratura, lei e República, como as mesmas são recepcionadas pelo calvinismo constitucional e recebem contribuições teóricas, compondo um ponto fundamental de transição de um discurso contratual e político para um constitucionalismo jurídico, assim como apresentaremos o contraste do pensamento de Bèze com o de Bodin e Hobbes, cuja noção de ambos acerca de magistratura se opõe categoricamente ao exercício de resistência por parte desses agentes políticos. 


\section{CAPÍTULO I - A PRUDÊNCIA DOS "PAIS" DA REFORMA E O ARROJO DOS “FILHOS" NO QUE TANGE AO DIREITO POLÍTICO DE RESISTÊNCIA}

Antes de adentrarmos no pensamento de Bèze sobre o poder civil e sua respectiva teoria política, que justifica um exercício de resistência às autoridades políticas tiranas, indicaremos em termos gerais as teorias políticas desenvolvidas pelos teólogos reformadores do século XVI.

Tal panorama teórico objetiva analisar a classificação clássica indicadora dos contrastes entre os reformadores magisteriais e radicais ${ }^{1}$, assim como compreender a assimilação do argumento de resistência constitucional, variável em graus de adesão entre os magisteriais, como também a impertinência do mesmo argumento para os reformadores radicais, uma vez que no cerne da teoria política destes últimos, estaria a possibilidade de inclusive uma dispensa do arcabouço operacional da vida civil, sobretudo dos magistrados e leis.

Deve-se entender o adjetivo magisterial como procedente da palavra magistratus, que designa, no século XVI, conselheiros, príncipes e reis, e não como derivado da palavra magisterium, ou seja, o magistério da Igreja, ou o ensinamento oficial do papa e bispos católicos $^{2}$, que inclusive é um dos aspectos do catolicismo mais combatido por quaisquer das categorias de reformadores.

Harro Höpfl descreve em termos quase fatalistas a relação entre o governo civil e o movimento da Reforma Protestante, já que os reformadores iniciais eram geralmente "clérigos sujeitos à disciplina eclesiástica", à exceção de Calvino, e que, portanto, somente poderiam estar liberados de seus compromissos com a Igreja oficial, como também poder dar livre curso a seus empreendimentos de reforma religiosa, se obtivessem o apoio dos governos seculares instituídos. ${ }^{3}$

Convergindo com a dinâmica acima descrita, no sentido de favorecer a Reforma Protestante com apoio secular, Höpfl expõe que historicamente "os governos seculares envolviam-se mais ou menos oficialmente com a administração, as finanças, o quadro burocrático e até mesmo com a doutrina da Igreja desde a fase final do Império Romano"4, de tal sorte que fatidicamente "tamanha era a interpenetração entre o secular e o espiritual no

\footnotetext{
${ }^{1}$ WILLIAMS, George Hunstston. La Reforma Radical. Cidade do México: Fondo de Cultura Economica, 1983, p. IX-X.

${ }^{2}$ Ibidem, p. X.

${ }^{3}$ HÖPFL, Harro. Sobre a Autoridade. Lutero e Calvino. São Paulo: Martins Fontes, 2005, p. IX (Introdução).

${ }^{4}$ Ibidem, p. IX.
} 
século XVI, que nenhuma reforma da religião poderia ser feita sem uma transformação da ordem pública nas unidades políticas da Europa cristã e nenhuma mudança nesse sentido poderia ser institucionalizada sem a assistência dos governos seculares.",

Ainda que Lutero e Calvino se colocassem mais como teólogos e homens atentos à Palavra de Deus do que pensadores ou homens políticos, o que não nos permitiria ter a expectativa de encontrar em seus escritos uma teoria política sistematizada, ocorre que "a Reforma da Igreja exigia a formulação de uma posição teológica geral e isso implicava inevitavelmente algumas afirmações centrais sobre a política e a filosofia política." 6

Tais reformadores eram constantemente demandados, por outros líderes da Reforma, a tratar de temas políticos, e respondiam com assertivas que, segundo eles, eram derivações de suas premissas teológicas e consequentes de uma mesma fonte, a Sagrada Escritura. $^{7}$

Posto esse pano de fundo, Lutero e Calvino tinham de examinar temas como "[...] o lugar do governo secular em relação ao projeto divino da salvação; a ligação entre o pecado e a autoridade temporal; as relações entre a lei divina, a lei natural e a lei positiva; as múltiplas implicações da doutrina cristã do homem, da Igreja e do Estado; os limites do poder político; os deveres mútuos do governo e dos súditos; e assim por diante." ${ }^{8}$

Ainda que existam diferenças importantes na teologia e na política de Lutero e de Calvino (em especial certas diferenças quanto ao direito de resistência), a seguir destacadas, em termos gerais, o arcabouço teórico de ambos acorda quanto ao embasamento nas mesmas autoridades, adotam em geral o mesmo método e estrutura, e as conclusões de seus pensamentos são suficientemente parecidas, o que nos permite tratá-las em conjunto ${ }^{9}$.

Para a compreensão da matriz comum do pensamento político de ambos os reformadores, é preciso a indicação do compartilhamento da tese geral agostiniana de que entre os homens haveria apenas a depravação total, não havendo nenhuma possibilidade de alguma boa obra que pudesse reverter essa realidade, pois aquilo que poderia parecer uma boa ação aos homens, não passaria de algo dramaticamente insuficiente em relação ao modelo de retidão que Deus requer de seus servidores, cabendo apenas à fé (sola fide) em Deus, a salvação do homem, de tal sorte que "nossa justificação é um dom sem mérito, gratuito, no

\footnotetext{
5 HÖPFL, Harro. Sobre a Autoridade. Lutero e Calvino. São Paulo: Martins Fontes, 2005, p. IX-X (Introdução).

${ }^{6}$ STRAUSS, Leo; CROPSEY, Joseph. Histoire de la Philosophie politique. Paris: Quadrige/PUF, 1994, p. 343.

${ }^{7}$ Ibidem, p. 343.

${ }^{8}$ Ibidem, p. 343-349.

${ }^{9}$ Ibidem, p. 344.
} 
qual toda participação de nossa parte é puramente e simplesmente deslocada, e a única retidão dos homens que não desaparece na presença de Deus é a 'a retidão passiva' que é dada livremente por Deus com a Fé."10

Essa dinâmica argumentativa leva os dois reformadores, verdadeiros patriarcas do movimento no século XVI, a reavivarem os ensinamentos de São Paulo e Agostinho, rompendo com o paradigma medieval tomista ou pelagianista, para o qual em algum sentido é possível pelas próprias forças, o homem obter sua salvação. ${ }^{11}$

Diante dessa realidade de perversão absoluta do gênero humano, verifica-se a necessidade incondicional dos homens viverem sob a égide de dois reinos ${ }^{12}$, construção teórica já perfilhada por Agostinho, descrita por Calvino nos seguintes termos:

Para que ninguém tropece nessa pedra, observemos que há um duplo regime do homem: um espiritual, mediante o qual se instrui a consciência na piedade e no culto de Deus; e outro político, pelo qual o homem é instruído em suas obrigações e deveres de humanidade e de educação que devem presidir as relações humanas. Em geral, costumam chamar-se de 'jurisdição espiritual' e 'jurisdição temporal', nomes muito apropriados, com os que se dá a entender que a primeira classe de regime se refere à vida da alma, e que a outra se aplica às coisas deste mundo, não somente para manter e vestir os homens, mas também para preescrever leis mediante as quais possam viver com seus semelhantes santa, honesta e modestamente. Porque a primeira tem sua sede na alma; a outra, em contrapartida, preocupa-se somente com os costumes exteriores. Ao primeiro, podemos chamar-lhe 'reino espiritual'; ao outro 'reino político ou civil'. Temos de considerar cada uma dessas coisas em si, segundo as distinguimos: com independência uma da outra. ${ }^{13}$

É importante notar que tais reinos não podem ser imediatamente identificados com as instituições da Igreja e do Estado, como ocorre em vários teóricos medievais, o que os

${ }^{10}$ STRAUSS, Leo; CROPSEY, Joseph. Histoire de la Philosophie politique. Paris: Quadrige/PUF, 1994, p. 346.

${ }^{11}$ Ibidem, p. 346.

${ }^{12}$ Skinner apresenta uma interpretação apoiada em Figgs, um tanto distinta da de Strauss e Cropsey da obra luterana, segundo a qual Lutero, ao defender radicalmente as autoridades seculares, dá cabo da batalha teológica travada desde os tempos medievais entre regnum e sacerdotium, suprimindo "a metáfora dos dois gládios; doravante, haverá apenas um, manejado por um príncipe de bom conselho e santa fé" FIGGS, J. N. The divine right of kings. 2. ed. Cambridge, 1914, p. 84, apud SKINNER, Quentin. As fundações do pensamento político. São Paulo: Cia das Letras, 2000, p. 297.

${ }^{13}$ CALVINO, João. A Instituição da Religião Cristã. Livro III, Cap. XIX. v. 2. São Paulo: Unesp, 2009, p. 306. 
levou, na visão desses reformadores, a uma divisão errônea ou a uma não distinção, culminando em desastre para a Igreja e para as comunidades políticas, pois: "A fronteira entre os dois reinos é uma divisão que se encontra em cada homem. Convenientemente examinadas, os dois governos operam principalmente sobre territórios, meios e em vista de fins diferentes, e quanto à superioridade de um sobre o outro, isso não se pode colocar com razoabilidade, pois em verdade, ambos devem cooperar entre si, mas somente na medida de não tornar confusa sua separação e igualdade diante de Deus." 14

Confusões desastrosas e diabólicas entre os dois reinos, sobretudo nas tentativas dos papistas em requisitar ao papa a autoridade secular universal em conflitos contínuos desde o fim de a Idade Média com os estados nacionais emergentes, ou ainda desprezo pela igual dignidade de ambos os reinos nos planos de Deus para a salvação humana, dessa vez, praticado, pelos radicais, acabam por compor o quadro de críticas direcionadas aos reformadores radicais pelos magisteriais.

Confusões entre as esferas de poder, geradas pelos papistas, que são censuradas por Lutero, nos seguintes termos:

No entanto, um mundo como este [que não respeita as distinções entre as esferas de poder] precisa de tais príncipes, onde nenhuma parte cumpre a função que lhe cabe. Os bispos hão de abandonar a palavra de Deus e não governarão as almas com ela. Confiam esse dever aos príncipes seculares, para que estes o executem pela espada. Por outro lado, os príncipes temporais hão de tolerar, ou praticarão eles mesmos, usura, roubo, adultério e outras obras más, para depois mandarem os bispos castigarem essas coisas com bulas e excomunhão, invertendo, dessa forma, maravilhosamente o sapato: as almas governam-nas com ferro, e o corpo, com cartas, de modo que os príncipes temporais governam espiritualmente, e os príncipes espirituais, temporalmente. Que outra coisa tem o diabo a fazer na terra, senão fazer gato e sapato de seu povo? São esses os nossos príncipes cristãos que defendem a fé e devoram o turco. De fato, bons companheiros, nos quais se pode confiar! Uma coisa conseguirão com essa inteligência maravilhosa: quebrarão o pescoço e lançarão o país e o povo em desgraça e miséria. ${ }^{15}$

${ }^{14}$ STRAUSS, Leo; CROPSEY, Joseph. Histoire de la Philosophie politique. Paris: Quadrige/PUF, 1994, p. 351-352.

${ }^{15}$ LUTERO, Martinho. Da Autoridade Secular. In: BONI, Alberto de (org.). Escritos Seletos de Martinho Lutero Tomás Müntzer e João Calvino. Petrópolis: Vozes, 2000, p. 111-112. 
O desprezo pela jurisdição civil em favor de uma supremacia espiritual, como ocorrida dentre os anabatistas, é expresso por Calvino nos seguintes preceitos de censura:

Porque, a respeito do que alegam, isto é, que na Igreja de Deus deve haver tal perfeição que faça as vezes de quantas leis existem, isso que imaginam é uma insensatez, pois jamais poderá existir tal perfeição em qualquer sociedade humana, visto ser tão grande a insolência dos malvados e sua perversidade tão contumaz e rebelde, que a duras penas pode-se manter a ordem, mesmo com o rigor das leis. Nessas condições, que se poderia esperar deles, se lhes fosse permitida uma liberdade tão desenfreada para fazer o mal, quando mesmo pela força quase não podem ser contidos ? $^{16}$

Porém, apesar das exortações acima sobre a necessidade de diferenciação entre $o s$ reinos secular e espiritual, é importante a sinalização de que em termos práticos, em suas respectivas contemporaneidades, os reformadores magisteriais sempre conseguiram impor aspectos religiosos de suas teologias nas administrações das comunidades políticas em que estavam envolvidos.

Harold Berman afirma que a Alemanha luterana promove uma verdadeira revolução político-jurídica, rompendo paradigmas como a jurisdição papal sobre os negócios eclesiásticos; alocando a competência para uma última instância decisória das mãos de órgãos eclesiásticos para os magistrados de cada principado: questões familiares, maritais, caridade pública e educação, e no bojo dessa nova realidade, o afastamento da aplicação da lei canônica, instituindo, portanto, autoridades e leis seculares num movimento de mão dupla (e aparentemente paradoxal), o de secularização da Igreja e ao mesmo tempo um processo de espiritualização do Estado. ${ }^{17}$

Um exemplo dessa interferência do reformador de Wittenberg na administração pública de seu tempo está na exortação de 1524, Aos Conselhos de todas as cidades da Alemanha, para que criem e mantenham escolas. Demanda aferida em larga medida pela nova fé que, ao instituir a supremacia do princípio Sola Scriptura, exigia o empreendimento de uma alfabetização da população sem precedentes, que na certa carecia do concurso dos poderes públicos para se efetivar. Após fazer um diagnóstico de abandono e desvirtuamento

\footnotetext{
${ }^{16}$ CALVINO, João. Poder Civil. In: BONI, Alberto de (org.). Escritos Seletos de Martinho Lutero Tomás Müntzer e João Calvino. Petrópolis: Vozes, 2000, p. 239-240

17 BERMAN, Harold J. Law and Revolution, II. Cambridge, Massachusetts, London, England: Harvard University Press, 1992, p. 6-8.
} 
das nobres finalidades da educação, Lutero clama pela necessidade de se optar primariamente pela educação do que por obras de infraestrutura (discussão em muito semelhante com as da atualidade sobre a destinação dos orçamentos públicos): “Caros senhores. Anualmente é preciso levantar grandes somas para armas, estradas, pontes, diques e inúmeras obras semelhantes, para que uma cidade possa viver em paz e segurança temporal. Por que não levantar igual soma para a pobre juventude necessitada, sustentando um ou dois competentes como professores ?"18

Calvino, apesar de uma vivência conturbada com a cidade de Genebra, comparada esta última, pelo cronista François Bonivard, ao povo hebreu, “difícil de lidar, mas eleito „19, após expulsões e repreensões do poder civil genebrino direcionadas a ele, consolida sua ascendência moral, não na condição de cidadão genebrino, mas de "simplesmente um funcionário do conselho" ${ }^{\text {20 }}$. Valendo-se de suas habilidades de jurista, era convocado como consultor, o que lhe conferia um papel influente nos negócios públicos de Genebra, chegando a "preparar uma constituição civil para a república" ${ }^{\text {21 }}$ genebrina ${ }^{22}$.

Além dos exemplos práticos de interferência na vida civil de seus tempos, em termos genéricos, em seus pensamentos políticos, numa aparente contradição à exigência de distinção entre os dois reinos, ambos entendiam que ao Estado cabia uma dupla função, com obrigações perante a Igreja, que não apenas autorizava, mas obrigava a purgá-la e reformá-la de acordo com a Palavra de Deus, dando-lhe forma de Igreja verdadeira, sem serem esquecidos os princípios de independência entre Igreja e poder secular. Outra competência

${ }^{18}$ LUTERO, Martinho. Aos conselhos das cidades da Alemanha, para que criem e mantenham escolas. In: LUTERO, Martinho, Obras selecionadas. v. 5. São Leopoldo: Comissão Interluterana de Literatura, 1995, p. 302-325.

${ }^{19}$ SILVESTRE, Armando Araújo. Calvino e a Resistência ao Estado. São Paulo: Editora Mackenzie, 2003, p. 94.

${ }^{20}$ COLLINSON, Patrick. A Reforma. Rio de Janeiro: Objetiva, 2006, p. 112.

${ }^{21}$ Ibidem, p. 113

${ }^{22}$ Detalhando melhor as ingerências de Calvino na vida política de Genebra, devido a sua formação jurídica, Maria Constança Peres Pissara mostra que: "e foi dentro desse espírito de fé reformada que, a pedido dos Conselhos, Calvino reorganizou também a ordem jurídica e política, estabelecendo os Éditos civis e Éditos políticos.

Para levar a bom termo essa revolução jurídica, primeiramente, Calvino fez aprovar, pelo Conselho Geral, o Édito do Lugar-tenente, principal instrumento de transformação do direito processual. Posteriormente, fez publicar os Éditos Civis, que, embora influenciados pelo direito romano na sua concepção, foram concebidos a partir de uma ampla compilação das leis genebrinas e valeram até o final do Antigo Regime.

Os Éditos políticos regulavam a organização dos poderes como também suas atribuições e prerrogativas, e foram publicados em 1543, sob o nome de Ordenanças sobre os ofícios e os oficiais. Embora os éditos de 1542 e 1543 tenham sido obra de Calvino, ele recorreu aos antigos éditos e foi influenciado pela corrente de ideias aristocráticas já existente em Genebra quando de sua chegada à cidade". PISSARA, Maria Constança Peres. A República genebrina. In: ROUSSEAU, Jean-Jacques. Cartas escritas da montanha. São Paulo: Unesp; PUC-SP, 2006, p. 23-24. 
atribuída à esfera política seria a obrigação de manter a vida social e a moralidade pública, perfazendo o Estado uma contenção contra o pecado ou "um remédio contra os vícios". 23

Porém, apesar dos pontos em comum acima mencionados, há uma diferença entre ambos. Em Lutero tais deveres do poder político, em cooperação com o reino espiritual se colocam em termos genéricos. Já Calvino os exprime com maior precisão ${ }^{24}$, conforme podemos ler nos comentários de Strauss e Cropsey sobre a obra dos reformadores ora em análise, e no próprio Calvino:

Mas, assim como há pouco recordamos que o governo civil é distinto do Reino espiritual e interior de Cristo, precisamos considerar que não se opõe a ele. Porque o reino espiritual nos dá, já aqui sobre a terra, uma antecipação do reino celeste, e nos dá, nesta vida mortal e transitória, certo gosto da bemaventurança imortal e incorruptível; mas o escopo do governo temporal é manter e conservar o culto divino externo, a doutrina e a religião em sua pureza, guardar a integridade da Igreja, levando-nos a viver com retidão, conforme exige a convivência humana por todo o tempo que vivemos, adequando assim nossos costumes à vida civil, a fim de manter e conservar a paz e a tranquilidade comuns. Admito que tudo isso seria supérfluo, se o reino de Deus, tal como se acha agora em nós, anulasse o interesse pela vida presente. Mas, se a vontade de Deus é que caminhemos sobre a terra, embora suspiremos pela verdadeira pátria, e se, além disso, tais meios nos são necessários à caminhada, então aqueles que os querem subtrair aos homens, pretendem lhes arruinar a própria natureza. Porque, a respeito do que alguns alegam, a saber, que na Igreja de Deus deve haver uma perfeição que se sirva como única lei, respondo que isso é insensatez, pois jamais poderá existir semelhante perfeição em nenhuma sociedade humana. De fato, sendo tão grande a insolência dos réprobos, e tão contumaz e rebelde sua perversidade que mal conseguimos refreá-las pelo rigor das leis, que deveríamos esperar se lhes fosse dada uma licença absoluta para fazerem o mal, visto que não se deixam conter nem mesmo pela força $?^{25}$

\footnotetext{
${ }^{23}$ STRAUSS, Leo; CROPSEY, Joseph. Histoire de la Philosophie politique. Paris: Quadrige/PUF, 1994, p. 356.

${ }^{24}$ Ibidem, p. 356.

${ }^{25}$ CALVINO, João. A Instituição da Religião Cristã. Livro IV, Capítulo XX. v. 2, São Paulo: Unesp, 2009 , p.877-876.
} 
Em suma, tanto para Lutero e Calvino como para os demais reformadores magisteriais que os sucederam, Igreja e Estado formam juntos uma unidade, na medida em que são uma e outro expressões da soberania de Deus, mas seria um erro desastroso tentar realizar essa unidade prematuramente, antes da consumação dos tempos, devendo ambos colaborarem entre si para o plano salvífico de Deus para o gênero humano, igual e separadamente. $^{26}$

Porém, apesar da semelhança do pensamento político, sobretudo quanto ao caráter magisterial da reforma perpetrada por ambos, convém ressaltar uma indicação feita por Leo Strauss e Joseph Cropsey, ao analisarem os aspectos formais da obra de ambos. Tais comentadores afirmam que Lutero e Calvino podem ser considerados antípodas no que concerne ao temperamento e à expressão, uma vez que:

Lutero é brilhante, vivo, impulsivo, muito agradável de ler, ele exagera frequentemente sua verdadeira opinião ou contradiz aquilo que ele disse anteriormente, afim de sublinhar um ponto com força. Ele não escreve nenhuma exposição geral de sua teologia, e é preciso coletar seu ensinamento político a partir de 'opúsculos destinados à época': tratados teológicos, comentários, sermões, e mesmo hinos. A despeito de quaisquer contradições de plano muito manifestas e exagerações, há uma unidade e uma coerência profundas em seu pensamento cuidadosamente elaborado e, no conjunto, ele mantém formulações muitas vezes consideradas embusteiras. Calvino é mais reservado, seco, claro e sistemático em seus escritos. Sua Instituição da Religião Cristã, escrita pela primeira vez quando ele tinha vinte e cinco anos, mas revista e desenvolvida em várias edições até 1599, é uma das maiores e mais influentes obras de teologia sistemática de todos os tempos. Sob sua última forma, ela fora a expressão definitiva de sua teologia, bem como se pode perfeitamente acrescentar ao caráter sistemático da obra de Calvino, a precisão temática aferida em seus numerosos sermões, conferências, comentários e correspondência ${ }^{27}$

\footnotetext{
${ }^{26}$ STRAUSS, Leo; CROPSEY, Joseph. Histoire de la Philosophie politique. Paris: Quadrige/PUF, 1994, p. 357.

${ }^{27}$ Ibidem, p. 344.
} 
Sob o rótulo de Reforma Radical, alberga-se uma série de movimentos e práticas religiosas durante o século XVI, num período entre 1517 e $1571^{28}$, compondo a década de 1520 o grande foco de levantes populares com sérias repercussões sobre a vida política em áreas hoje compreendidas principalmente pela Alemanha e Suíça.

O núcleo do pensamento e práticas político-devocionais desses protestantes

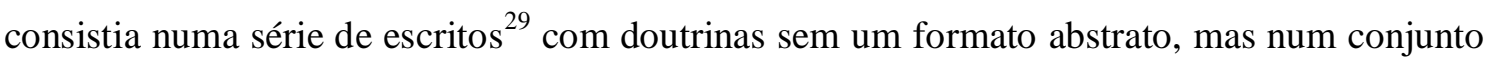
de:

[...] normas para viver, valores e princípios práticos sobre como a vida sóciopolítica deveria ser conduzida entre pessoas que se denominam cristãs. Nesse sentido, sua teoria política era implícita, um senso de moralidade social encravada na vida cotidiana. Em essência sua economia moral era conservadora, construída de noções tradicionais. Cristãos deveriam viver juntos em harmonia e paz, como irmãos e irmãs, e praticar a caridade em relação uns aos outros; o bem-estar da coletividade deveria ter precedência sobre vantagens privadas individuais; e se disputas se levantassem elas deveriam ser resolvidas pela lei divina, como um modelo de justiça derivado da Escritura. ${ }^{30}$

Num primeiro contato, tais princípios aparentam ser perfeitamente compatíveis com quaisquer dos ramos do cristianismo. O problema, que conferiria justamente o caráter de radical ao movimento, seria o fato desses tidos como radicais terem atribuído aos princípios acima citados "um significado específico e diferente", também compartilhado pela arraia miúda sob sua influência, consistente na percepção de que "a economia moral da sociedade

\footnotetext{
${ }^{28}$ WILLIAMS, George Hunstston. La Reforma Radical. Cidade do México: Fondo de Cultura Economica, 1983, p. x.

${ }^{29}$ Os principais escritos desse ramo da Reforma para Michael G. Baylor seriam: O manifesto de Praga (Tomás Müntzer); Sermão para os Príncipes ou Uma exposição do Segundo Capítulo de Daniel (Tomás Müntzer); Carta da Comunidade de Orlamünde para o Povo de Allstedt (Andreas Karlstadt); Carta para Tomás Müntzer (Conrad Grebel); Se se deve proceder com vagar (Andreas Karlstadt); Uma defesa altamente provocada (Tomás Müntzer); Protesto e Defesa (Félix Manz); Para a Assembleia dos Camponeses Comuns (Anônimo); Sobre a Lei de Deus (Hans Denck); Sobre o Mistério do Batismo (Hans Hut); Os Artigos de Schleitheim (Michael Sattler); Sobre a Espada (Baltasar Hubmaier); Sobre a Transformação da Vida Cristã (Hans Hergot); Como exposições programáticas do período de guerra dos camponeses, Baylor arrola: Os Onze Artigos de Mülhlhausen; Os Doze Artigos dos Altos Camponeses Suábios; A Constituição Federal de Memmingen; O Documento de Artigos dos Camponeses da Floresta Negra; Os Quarenta de Seis Artigos de Frankfurt; Constituição Territorial para o Tirol (Miguel Gaismair). BAYLOR, Michael G. The Radical Reformation. Cambridge: Cambridge University Press, 1991, p. XXX.

${ }^{30}$ BAYLOR, Michael G. Op.cit., p. xviii.
} 
estava deslocada, e o comportamento do clérigo e dos magistrados seculares contradiziam os valores por eles professados ${ }^{, 31}$.

Como consequência dessa percepção, em contraste com os reformadores clássicos, os radicais defendiam uma separação entre suas igrejas e as magistraturas constituídas dos territórios nos quais viviam ${ }^{32}$, não reconhecendo em regra o caráter colaboracionista que os poderes seculares constituídos a priori do movimento de renovação da fé, poderiam ter no plano de salvação do gênero humano, em paralelo à organização eclesiástica, como era defendido por Lutero e Calvino, que sempre almejavam apoio dos poderes civis para dar cabo a suas formulações religiosas.

Ou ainda, conforme explica Baylor: "o mais característico dos traços da reforma radical era que, diferentemente dos reformadores magisteriais, os radicais legitimaram a existência de uma autoridade política contingente na sua boa vontade de servir ao evangelho e nas necessidades da comunidade. O Sermão para os Príncipes de Müntzer foi também um ultimato: se existir magistrado que não realiza as funções próprias de governo, a comunidade assumiria o poder para fazer isso. „33

George H. Williams reconhece dentro da diversidade dos movimentos que são classificados sob a designação de reforma radical três tendências principais: o anabatismo, $o$ espiritualismo e o racionalismo evangélico, que comporiam uma terceira força no cenário religioso multifacetado do século XVI, junto com o protestantismo clássico ou reforma magisterial, que continha em si um quadro já bastante diversificado (luteranismo, calvinismo, a igreja estabelecida na Inglaterra) e mesmo a Contra-reforma do catolicismo romano que, ainda que unificada e encabeçada pelo papa, não deixava de ter divisões internas, com muitas ordens religiosas envolvidas na execução ${ }^{34}$ da resposta ao movimento reformador do cristianismo de então.

Para o comentador acima citado, a reforma radical apresentaria elementos que fazem confluir "o velho e o novo", conforme atesta a literatura especializada que se polariza sobre o tema, uma vez que, para alguns, "a Reforma Radical constitui primeiramente a protestantização aguda e coerente do cristianismo no século XVI”35, e para outros representaria: "a sobrevivência, o robustecimento e a expansão extraordinária de modalidades

\footnotetext{
${ }^{31}$ BAYLOR, Michael G. The Radical Reformation. Cambridge: Cambridge University Press, 1991, p. xviii.

32 WILLIAMS, George Hunstston. La Reforma Radical. Cidade do México: Fondo de Cultura Economica, 1983, p. 6.

${ }^{33}$ BAYLOR, Michael G. Op. cit., p. xvii.

${ }^{34}$ WILLIAMS, George Hunstston. Op. cit., p.ix.

${ }^{35}$ Ibidem, p. 3.
} 
cristãs essencialmente medievais de piedade e formas de governo, de espiritualidade popular e de impulsos de reforma conventual e sectária, misturado tudo isso, aos turbilhões e reflexos do grande clamor religioso e social da época. "36

Mais precisamente, aspectos que aproximariam a Reforma Radical do catolicismo medieval, dentre outros, seriam um afastamento da autoridade bíblica exclusiva como fonte de fé, a pouca importância conferida às consequências da caída de Adão, ou seja, do pecado original (que tanto obcecava Lutero e Calvino), o que levava à consideração do livre-arbítrio em cooperar com a graça, além de uma manifestação de um misticismo popular e a proclamação missionária da fé renovada. ${ }^{37}$

Já os aspectos protestantes consistiriam no rechaço à primazia papal, assim como à sucessão apostólica dos bispos: na não aceitação do ensinamento da doutrina cristã monopolizada pelo papa e bispos, quer individualmente considerados ou reunidos em concílios; na não consideração da tradição como uma fonte da fé equiparável à Escritura; na redução dos sacramentos a dois, e o sacerdócio universal de todos os crentes, como foi dito por Lutero em $1520 .^{38}$

Dentre todas as práticas religiosas com sérias repercussões na vida civil, e que justificaria a designação de radicais, na certa destaca-se a negativa do batismo às crianças (prática não exclusiva dos anabatistas), uma vez que, partindo-se do princípio do não cabimento de uma distinção autonomamente reconhecível entre a vida religiosa e civil das pessoas, o batismo deve ser considerado naquela época "um rito de admissão na vida política para os cristãos, uma aceitação do contrato social [...] Recusar ter uma criança batizada, [...] era repudiar os vínculos que conectavam ambos os pais e a criança com a igreja e a sociedade. 39

Os levantes populares eclodidos durante a década de 1520 foram duramente censurados por Lutero como se lê:

Esses camponeses colocam sobre si três pecados contra Deus e os homens, pelo que merecem multiplamente a morte do corpo e da alma. [...] $\mathrm{O}$ primeiro, é que juram à sua autoridade fidelidade e respeito, bem como submissão e obediência, como Deus o ordena, dizendo: 'Daí a César o que é

\footnotetext{
${ }^{36}$ WILLIAMS, George Hunstston. La Reforma Radical. Cidade do México: Fondo de Cultura Economica, 1983 , p. 3.

${ }^{37}$ Ibidem, p. 4.

${ }^{38}$ Ibidem, p. 4.

${ }^{39}$ BAYLOR, Michael G. The Radical Reformation.Cambridge: Cambridge University Press, 1991, p. xvii.
} 
de César', e em Rm 13,1: 'Todo homem seja sujeito à autoridade'. Mas pelo fato de quebrarem maligna e criminosamente essa obediência e ainda se oporem a seus senhores, com isso comprometem corpo e alma, como os patifes e malfeitores desleais, perjuros, mentirosos e desobedientes costumam fazer. [...] O segundo pecado é por causarem tumulto, roubarem e saquearem criminosamente conventos e castelos, que não lhes pertencem, pelo que, certamente, como notórios assaltantes de estradas e assassinos, já merecem duplamente a morte de corpo e alma.[...] O terceiro é que encobrem com o Evangelho tal pecado terrível e horripilante, denominam-se irmãos cristãos, prestam juramento. aceitam reverências e obrigam as pessoas a acompanhá-los em tais horrores ${ }^{40}$

Mas importa o registro de que o estopim dos levantes camponeses, dentre outros fatores, foi as condenações e ameaças que o próprio Lutero vinha sofrendo, marcando o fim de uma solidariedade inicial existente entre reformadores magisteriais e radicais.

Posto esse pano de fundo, percebe-se que luteranos e calvinistas, a partir de 1530, se reafirmarão como magisteriais, para que não sejam confundidos como radicais, porém atestam o dever dos magistrados inferiores de combate a tiranias perpetradas por seus superiores.

No entanto, apesar de apresentarem uma literatura política com objetivos em comum, sobretudo o de chancelar a licitude do exercício de resistência política face às tiranias, ambos apresentam uma diferença de paradigma, já que luteranos fundamentam-se de forma mais pautada na autoridade bíblica (ainda que tal embasamento, em verdade, para Skinner, teria sua origem em uma readequação da exegese bíblica, influenciada por argumentos seculares de resistência extraídos do Digesto e das leis fundamentais do Sacro Império Romano Germânico), e a fundamentação de calvinistas que, muito além de reafirmarem os argumentos teológicos dos luteranos, desenvolvem amplamente a discussão num paradigma secular de resistência. ${ }^{41}$

\footnotetext{
${ }^{40}$ LUTERO, Martinho. Contra as Hordas Salteadoras e Assassinas dos Camponeses. In: BONI, Alberto de (org.). Escritos Seletos de Martinho Lutero Tomás Müntzer e João Calvino. Petrópolis: Vozes, 2000, p. 167168.

${ }^{41}$ SKINNER, Quentin. As fundações do pensamento político. São Paulo: Cia das Letras, 2000, p. 465-512.
} 


\subsection{A exortação de Paulo aos romanos}

Paulo, no seu intento de cristianização do mundo mediterrâneo, assim assevera às comunidades cristãs recém-estruturadas em Roma, capital do Império que, em última análise, segundo as narrativas da fé cristã, havia penalizado da pior forma possível seu mestre com a crucificação (gerando portanto uma justa expectativa de revide), a resignação:

Cada um se submeta às autoridades constituídas, pois não há autoridade que não venha de Deus, e as que existem foram estabelecidas por Deus. De modo que aquele que se revolta contra a autoridade, opõe-se à ordem estabelecida por Deus. E os que se opõem atrairão sobre si a condenação. Os que governam incutem medo quando se pratica o mal, não quando se faz o bem. Queres então não ter medo da autoridade? Pratica o bem e dela receberás elogios, pois ela é instrumento de Deus para te conduzir ao bem. Se, porém, praticares o mal, teme, porque não é à toa que ela traz a espada: ela é instrumento de Deus para fazer justiça e punir quem pratica o mal. Por isso é necessário submeter-se não somente por temor do castigo, mas também por dever de consciência. É também por isso que pagais impostos, pois os que governam são servidores de Deus, que se desincumbem com zelo de seu ofício. Dai a cada um o que lhe é devido: o imposto a quem é devido; a taxa a quem é devida; a reverência a quem é devida; a honra a quem é devida. ${ }^{42}$

O trecho acima, segundo Harro Höpfl, tem tamanha importância no pensamento político reformador, que poderia ser compreendido em todo o seu conjunto, em larga medida como um mero comentário dele ${ }^{43}$.

Para J. C. O’ Neill tais versículos se prestaram a uma verdadeira licença aos tiranos, quer no Ocidente ou no Oriente cristãos, convenientemente manejados para justificar as mais diversas atrocidades ${ }^{44}$.

Para Lutero, em seu escrito de 1522, Prefácio à Epístola de São Paulo aos Romanos, tal parte do novo testamento é alçada à dignidade de "a parte verdadeiramente

${ }^{42}$ Romanos 13, 1:7. In: Bíblia de Jerusalém. São Paulo: Paulus, 2006, p. 1987.

43 HÖPFL, Harro. Sobre a Autoridade. Lutero e Calvino. São Paulo: Martins Fontes, 2005, p. XXIII (Introdução).

${ }^{44}$ O’ NEILL, J. C. Paul' s Letter to the Romans. London: Penguin, 1975, p. 209, apud ELLIOTT, Neil. Romanos 13, 1-7 no contexto da propaganda imperial. In: HORSLEY, Richard A. Paulo e o império, religião e poder na sociedade imperial romana. São Paulo: Paulus, 2004, p. 184. 
principal do Novo Testamento e o mais puro de todos os Evangelhos" merecedora de que o cristão não só a saiba de cor, palavra por palavra, mas que se ocupe com ela diariamente, como se fosse o pão diário da alma, pois ela jamais poderá ser lida ou contemplada em demasia e devidamente bem." 46

Dentre os reformadores magisteriais como Lutero, Calvino e Bèze, o excerto em tela, prestou-se tanto como fundamento da legitimidade do poder civil frente ao papado ${ }^{47}$, mas sobretudo, como argumento de neutralização das teses dos reformadores radicais ${ }^{48}$, o que numa primeira leitura descontextualizada e parcial dos precursores do luteranismo e do calvinismo levaria a crer que os mesmos chancelassem atrocidades perpetradas por tiranos, com base nas notórias palavras de Paulo.

Porém, conforme veremos adiante, tais reformadores em distintos graus de adesão, também aceitaram o direito de resistência; além disso, Paulo, segundo os mais recentes estudos teológicos, deve ser interpretado, principalmente nesse trecho de sua Carta aos Romanos, de acordo com as circunstâncias da época e, de forma alguma, o texto deve ser considerado um permissivo universalmente válido de desmandos dos maus governantes.

Neil Elliott, a partir de um minucioso estudo sobre os elementos retóricos presentes na carta, principalmente os irmanados com o da propaganda imperial "da espada inativa” dos tempos de Nero ${ }^{49}$, mostra que a Paulo não cabia outra saída, ao perceber que, apesar da propaganda da "espada não-desembainhada”, o império continuava a perpetrar

${ }^{45}$ LUTERO, Martinho. Da Liberdade do Cristão (1520). São Paulo: Editora Unesp, 1997, p. 83, Prefácio à Epístola de São Paulo aos Romanos (1522).

${ }^{46}$ Ibidem, p. 83.

${ }^{47}$ LUTERO, Martinho. Da autoridade Secular. In: BONI, Alberto de (org.). Escritos Seletos de Martinho Lutero Tomás Müntzer e João Calvino. Petrópolis: Vozes, 2000, p. 85.

${ }^{48}$ LUTERO, Martinho. Sobre a Liberdade Cristã. In: BONI, Alberto De. Op. cit., p. 47; CALVINO, João. Poder Civil. In: BONI, Alberto de (org.). Op.cit., p. 258; BÈZE, Théodore de. Du Droit des Magistrats. Genève: Droz, 1970, p. 10.

49 A ideia de "espada inativa ou não-desembainhada" consiste na alteração da propaganda imperial na época de Nero, que "em explícito contraste com a Pax Augusta, a paz de Nero não foi estabelecida por meio da guerra. Seus propagandistas assumiram a tarefa sem precedentes de tecer loas ao próprio apagamento da lembrança da guerra”. (ELLIOTT, Neil. Romanos 13, 1-7, no contexto da propaganda imperial. In: HORSLEY, Richard A. Paulo e o império, religião e poder na sociedade imperial romana. São Paulo: Paulus, 2004, p. 200). Dentre os autores latinos que se prestaram de vetor a tal construção e propagar ideológico, destacam-se poetas latinos menores como Calpúrnio Sículo ou ainda as éclogas de Einsiedeln, porém o texto que talvez melhor expresse tal propaganda seja o De Clementia (Sobre a Misericórdia) de Sêneca, preceptor e conselheiro de Nero que propõe ao imperador uma melhor reflexão sobre seu poder absoluto, conforme verifica-se na seletiva de trechos do discurso ora referido feita por Neil Elliott: "Sou o árbitro da vida e da morte para as nações... Todos os tantos milhares de espadas que minha paz contém serão desembainhadas a um gesto meu; que nações sofrerão grande destruição, quais serão banidas..., cabe a mim decretar. Tendo tudo isso à minha disposição, não fui movido pela raiva nem pelo impulso juvenil `a punição injusta... Comigo, a espada está oculta, ou melhor, em sua bainha; poupo ao máximo mesmo o sangue menos nobre; nenhum homem deixará de encontrar favor em minhas mãos ainda que lhe falte tudo o mais, exceto o nome do homem." (SÊNECA. Sobre a misericórdia 1.2-4, apud ELLIOT, Neil. Op. cit., p. 201). 
atrocidades principalmente em relação aos judeus, e não seria de todo descabido lembrarmos que o Cristianismo, em suas origens, era frequentemente confundido, ou ao menos recepcionado como uma seita judaica pelos gentios.

Dessa maneira, a interpretação mais acertada para as palavras de Paulo seria vêlas como um instrumento de pacificação momentânea e, sobretudo, protetora das comunidades pobres de Israel, e para isso, fazia-se urgente "estimular a submissão, então, às autoridades, em vez da resistência desesperada; e, assim, salvaguardar os mais vulneráveis em torno e no meio dos cristãos romanos, os judeus que lutavam por reconstruir sua comunidade abalada na esteira da violência imperial." ${ }^{50}$ Isto posto, "só as mais perniciosas reviravoltas do destino iriam mais tarde arrolar esses versículos como estando a serviço do próprio Império "51, e de outras espécies de governos tirânicos.

\subsection{A reforma protestante e seu patriarcado agostiniano}

Quentin Skinner apresenta a reforma protestante iniciada por Lutero como um desdobramento esperado das tensões entre dois catolicismos que se arrastavam ao longo da Idade Média: "Essa convicção de Lutero [a completa degeneração da humanidade pela queda de Adão e sua transmissão por hereditariedade] levou-o a rejeitar a ideia otimista de um homem apto a intuir e seguir as leis de Deus - concepção essa essencial para os tomistas -, e a retornar à insistência com que, séculos antes, santo Agostinho tratara, com não pouco pessimismo, da natureza decaída do homem." 52

Ainda que em Agostinho não se encontre um pensamento político sistematizado, várias gerações que se debruçaram sobre sua obra vislumbram em suas visões sobre a vida civil um conjunto harmônico e coerente e, dentre todas as suas obras, Paul Weithman aponta A Cidade de Deus, como "a mais rica fonte de material político em todo o corpo da literatura de Agostinho”, obra em que o bispo de Hipona se ocupa de dar respostas àqueles que acusam

\footnotetext{
${ }^{50}$ ELLIOTT, Neil.Romanos 13, 1-7 no contexto da propaganda imperial. In: HORSLEY, Richard A. Paulo e o império, religião e poder na sociedade imperial romana. São Paulo: Paulus, 2004, p. 202.

${ }^{51}$ Ibidem, p. 202.

${ }^{52}$ SKINNER, Quentin. As fundações do pensamento político. São Paulo: Cia das Letras, 2000, p. 285-286.
} 
o advento do Cristianismo e sua propagação como responsáveis da pilhagem ocorrida em Roma no ano de $410 .^{53}$

Sobre a natureza decaída do gênero humano, em decorrência do mau uso do livrearbítrio que levara ao pecado primordial dos primeiros pais da humanidade, Adão e Eva, temática tão recorrente e fundamental a Lutero e aos demais reformadores de século XVI, assim como a respectiva responsabilidade de todos os descendentes desses primeiros pais, que transmitiriam sua culpa a todos seus descendentes por hereditariedade, Agostinho a explica da seguinte forma, em sua Cidade de Deus, no Livro XIII, Capítulo XIV:

Deus, Autor da natureza, não dos vícios, criou o homem reto; mas, depravado por sua própria vontade e justamente condenado, gerou seres desordenados e condenados. Estivemos todos naquele um quando fomos todos aquele um, que caiu em pecado pela mulher, dele feita antes do pecado. Ainda não fora criada e difundida nossa forma individual, forma que cada qual víamos de descender de todos. Desta, viciada pelo pecado, ligada pelo vínculo da morte e justamente condenada, o homem, nascendo do homem, não nasceria doutra condição. Por isso, do mau emprego do livrearbítrio originou-se verdadeira série de desventuras, que de princípio viciado, como se corrompido na raiz o gênero humano, arrastaria todos, em concatenação de misérias, ao abismo da morte segunda, que não tem fim, se a graça de Deus não livrasse alguns. ${ }^{54}$

Devido à dinâmica do binômio queda e salvação do gênero humano, Agostinho vislumbra a concomitância de Duas Cidades, uma Cidade terrena, e outra Cidade de Deus. A primeira seria fundada com base no "amor próprio, levado ao desprezo a Deus", e uma segunda cujas bases repousariam no "amor a Deus levado ao desprezo de si próprio", de modo que enquanto na primeira haveria a auto-glorificação de seus domínios, na segunda haveria uma "mútua caridade, os governantes aconselhando, e os súditos [obesequiosamente], obedecendo." $" 55$

De uma forma incipiente em relação àquilo que seria lido séculos depois em Lutero, afere-se em Agostinho o mesmo argumento encontrado no reformador de Wittenberg,

\footnotetext{
${ }^{53}$ WEITHMAN, Paul. Augustine' s political philosophy. In: KRETZMANN, Norman; STUMP, Eleonore. The Cambridge Companion to Augustine. Cambridge: Cambridge University Press, 1993, p. 234-235.

54 Agostinho. A Cidade de Deus Contra os Pagãos. v. 2. Bragança Paulista: Ed. Universitária São Francisco, 2006, p. 109.

${ }^{55}$ Ibidem, p. 169.
} 
de que os justos, entendendo-se como tais os cristãos ou os tementes guardiões dos preceitos divinos narrados no Antigo Testamento, e que seriam pertencentes à Cidade de Deus, por altruísmo puro e simples, sem nenhuma necessidade de assim proceder, já que não cometem crime algum, sujeitam-se às autorides civis e suas respectivas leis, até pelos fins pedagógicos que tal atitude carrega em si, para a tão carecida de freios e admoestações, ou mesmo penalidades, que é a Cidade dos Homens.

Agostinho, rememorando exortações bíblicas, assim descreve o comportamento da cidade altruísta e aberta à santidade, que obesequiosamente se sujeita a fardos pesados: "Diz-se, por isso, aos capazes e bons, que em seu peregrinar vivem da fé: Levai as cargas uns dos outros e assim cumprireis a lei de Cristo. E noutra parte: Corrigi os inquietos, consolai os pusilânimes, alentai os débeis e sede pacientes com todos. Evitai, pois, que alguém retribua a outrem mal por mal. E noutro lugar: Se alguém andar preocupado com algum delito, instrui-o vós, que sois espirituais, com espírito de mansidão, pensando que também podeis ser tentados. $" 56$

Paul Weithman aponta como um verdadeiro "espelho para os príncipes" o Livro X da obra do bispo discípulo de Ambrósio, ora em análise, sobretudo quando narram-se e louvam-se as condutas de imperadores cristãos que repugnam as glórias mundanas e o amor de si próprios e se comprometem com o verdadeiro Deus e seu amor, o que indiscutivelmente leva ao bem-estar maior de seus governados, uma vez que tais imperadores se mostram misericordiosos, pacíficos, e justos, além de se porem completamente à disposição da vontade divina.

Assim descreve Agostinho as práticas modelares de tais governantes, que deveriam ser observadas por todo aquele que detém alguma forma de mando sobre a Terra:

[...] chamamo-los de felizes, se imperam com justiça, se não se parvoneiam entre as línguas pródigas em sublimes louvores e entre os obséquios dos que humildemente os saúdam, mas se lembram de serem homens, se colocam seu poder aos pés da Majestade divina para, principalmente, estender-lhe o culto, se temem, amam e adoram Deus, se preferem o reino onde não temem ter príncipes, se se mostram tardos em vingar e prontos a perdoar, se tiram vingança por necessidade da administração e defesa da república, e não para deixar impune a justiça, mas pela esperança de emenda, se, quando muitas

\footnotetext{
56 Agostinho. A Cidade de Deus Contra os Pagãos. v. 2. Bragança Paulista: Ed. Universitária São Francisco, 2006, p. 179.
} 
vezes se veem obrigados a ordenar com aspereza, o compensam com suavidade misericordiosa e com largueza de benefícios, se a luxúria está neles tanto mais sujeita quanto mais livre poderia estar, se a senhorear quaisquer nações preferem dominar seus maus apetites, se não fazem tudo isso pela ânsia de vanglória, mas por dileção pela felicidade eterna, se não descuidam de, por seus pecados, imolar ao Deus verdadeiro que tais imperadores cristãos são felizes nesta peregrinação e depois o serão na realidade, quando se cumprir o que esperamos. ${ }^{57}$

Tais exortações de Agostinho em muito se aproximam das recomendações aos príncipes que faziam os reformadores magisteriais aos seus governantes, em circunstâncias históricas também relativamente semelhantes àquelas vividas por Agostinho, que seriam as de trasição de uma antiga para uma nova fé, que carece de legitimação ou de tolerância mínima das autoridades civis para seu desenvolvimento, ou ao menos para sua sobrevivência.

Desse modo, vê-se já em Agostinho os fundamentos da reforma magisterial, no sentido de se afirmar de modo inequívoco a legitimação das autoridades civis e seus mecanismos de controle social daqueles irredentos que marcham sob as sombras da Cidade dos Homens, promovendo a contenção dos piores efeitos das más inclinações humanas, relacionando tal legitimação dos poderes constituídos com a própria bondade de Deus para com os homens, uma vez que ela viabiliza a vida cotidiana dentre degenerados irredutíveis.

\subsection{0 quase nulo grau de adesão de Lutero ao direito de resistência}

Lutero, notabilizado por ser o primeiro reformador cujo empreendimento de renovar as bases do credo cristão ocorreu de forma bem-sucedida, elabora no bojo de seu pensamento teológico considerações sobre a vida política que prestigiam a ordenação civil do mundo como, inclusive, uma arma fundamental de cooperação com os desígnios de Deus para o genêro humano.

Dentre as obras que se apresentam de forma menos apaixonada, sob o aspecto da combatividade aos manifestos, pregações e práticas dos reformadores radicias e mais

${ }^{57}$ AgOSTINHO. A Cidade de Deus Contra os Pagãos. v. 2. Bragança Paulista: Ed. Universitária São Francisco, 2006, p. 226. 
objetivamente de cunho político, "deixando de lado os escritos de circunstâncias, exortações à paz social ou condenações irritadas e frequentemente ultrajantes à revolta dos campesinos", na concepção de Pierre Mesnard, estariam as seguintes: Sobre a autoridade secular, de 1523 e Acerca da questão, se também militares ocupam uma função-aventurada, de $1526 .{ }^{58}$

Em Sobre a Autoridade Secular, de 1523, dedicada ao seu soberano imediato o Duque da Saxônia, landgrave da Turíngia e margrave de Meissen chamado João, Lutero expõe de forma inequívoca a pertinência e perfeita compatibilidade da instituição do governo temporal com as verdades evangélicas, em qualquer circunstância, contrariando as pregações de Müntzer e outros reformadores radicais.

Já em suas primeiras páginas, o tratado aponta a necessicidade de se afastar as ideias dos sofistas, que em verdade são os escolásticos, uma vez que Lutero explicita sua intenção de que os mandamentos contidos na Escritura devem ser encarnados como mandamentos universais e não meros "conselhos para os perfeitos" ${ }^{\text {"59 }}$ como argumentavam os anteriores.

Num primeiro tópico, deixa claro que o mundo secular e seus meios de execução são existentes graças única e exclusivamente à "vontade e ordenação de Deus". Após uma série de exemplos bíblicos tanto do Antigo como do Novo Testamento, alegando em última análise a confirmação de Cristo ao que já fora estabelecido antes de sua encarnação, a exemplo das passagens do Gn 9, 6 e Ex 21, 14, no qual se estabelece a pena capital para os homicidas, nos evangelhos, Lutero identifica a confirmação dessa lei, pois assim disse Cristo: “Quem tomar a espada, pela espada morrerá (Mt 26, 52)”. E mais precisamente no evangelho de Lucas encontra-se a justificativa das ações do poder civil, quando João Batista diz aos soldados: "Contentai-vos com vosso soldo (Lc 3,14)"; o profeta primo de Cristo apenas os exorta a não cometer injustiças, mas de forma alguma os censura pelo ofício de empulhar a espada em nome da autoridade pública. Dessa forma, embasando-se também em outros exemplos extraídos das Escrituras, dogmatiza: "portanto, é certo e suficientemente esclarecido que é da vontade de Deus que a espada e o direito secular sejam usados para castigar os maus e proteger os piedosos." 60

58 MESNARD, Pierre. L'essor de la Philosophie Politique au XVI Siècle. Paris: Libraire Philosophique J. Vrin, 1977, p. 202.

59 LUTERO, Martinho. Da Autoridade Secular. In: BONI, Alberto de (org.). Escritos Seletos de Martinho Lutero Tomás Müntzer e João Calvino. Petrópolis: Vozes, 2000, p. 82-83.

${ }^{60}$ Ibidem, p. 86. 
Tal funcionalidade a que se refere Lutero, do gládio e do direito secular para castigar os maus, deve-se ao fato de ter sido a humanidade dividida em dois grupos distintos, numa clara referência à Cidade de Deus de Agostinho. Assim diz Lutero: "uns pertencem ao reino de Deus, os outros, ao reino do mundo". É evidente para Lutero que não há necessidade, por parte do primeiro grupo, dos mecanismos de poder para repreendê-los, uma vez que: “o justo faz, por si mesmo, tudo e mais ainda do que o exigido por todas as leis. Os injustos, em contraposição, nada fazem que seja justo; por isso necessitam da lei que os ensina, obriga e pressiona para agirem bem.",61

Porém, sob a ótica de Lutero, apesar dos cristãos verdadeiros e não apenas nominais prescindirem das leis e magistraturas, os mesmos obsequiosamente se sujeitam a tais artefatos da vida civil para que haja um mínimo de tranquilidade na jornada terrena dos homens, além de tal comportamento se prestar como exemplo aos refratários a uma sincera conversão e aos malfeitores, que tanto necessitam do gládio do poder civil.

Ainda em sua obra Sobre a Autoridade Secular, Lutero, em posição diametralmente oposta aos reformadores radicais, não apenas louva e legitima a existência das autoridades civis, como também perfila seu ideal de governante, extremamente comprometido com os ditames divinos, que em muito se aproxima do modelo figurado por Agostinho em sua descrição dos imperadores cristãos; ou seja, um paradigma de subserviência a Deus e moderação no sensato uso do poder:

[...] o príncipe deve dividir suas atenções em quatro sentidos: 1) Em relação a Deus deve ter verdadeira confiança e [dirigir-se a Ele em] oração sincera; 2) em relação aos súditos deve agir com amor e serviço cristão; 3) em relação a seus conselheiros e plenipontenciários deve manter-se livre nas decisões e independente no discernimento; 4) em relação aos delinquentes deve mostrar seriedade e rigor moderado. Dessa maneira confirmará sua função exterior e interiormente, agradando a Deus e às pessoas. No entanto, deve estar preparado para muita inveja e sofrimento. Muito em breve a cruz pesará sobre um tal propósito. ${ }^{62}$

${ }^{61}$ LUTERO, Martinho. Da Autoridade Secular. In: BONI, Alberto de (org.). Escritos Seletos de Martinho Lutero Tomás Müntzer e João Calvino. Petrópolis: Vozes, 2000, p. 88.

${ }_{62}$ Ibidem, p. 121. 
Em Acerca da questão, se também militares ocupam uma função bem-aventurada, de 1526, Lutero reafirma suas teses gerais como a dos reinos secular e espiritual, aborda a questão do direito de resistência de uma forma mais sofisticada que nos escritos anteriores.

Após fazer uma ampla condenação da popularização de qualquer movimento do populacho que intente a libertação de seu jugo por tiranos, e mesmo condenar os precedentes da história secular de tiranicidas ${ }^{63}$, Lutero aborda uma questão de fundo constitucional: se um governante deve ou não respeitar as leis de seu país ou as de Deus. Responde que nada pode ser feito caso forem violadas, uma vez que:

Consta que o rei da França deve governar de acordo com os parlamentos do seu reino, e que o rei da Dinamarca também é obrigado a prestar juramento sobre artigos especiais, etc. [...] é equitativo e ótimo que a autoridade governe seguindo leis e as aplique, em vez de reinar de acordo com o arbítrio próprio. Acrescento, porém, ainda, que um rei não somente se compromete a observar artigos ou o direito do país, mas o próprio Deus também lhe ordena a ser reto e ele mesmo também promete sê-lo. Muito bem, e se agora um rei desses não observa nenhum desses pontos, nem o direito de Deus, nem o direito de seu país? Deverias tu atentar contra ele por isso, para julgá-lo e tomar vingança contra ele? Quem te mandou? Seria necessário que outra autoridade interviesse entre vós, que interrogasse a ambos e condenasse o culpado. Caso contrário não escaparás à sentença de Deus, na qual ele diz:

'Minha é a vingança'; e ainda: 'Não julgareis', Mt 7.1. ${ }^{64}$.

Ou seja, para Lutero, em princípio, os parâmetros normativos de um reino, ou qualquer outra comunidade política, em relação a um governante apenas teriam eficácia

\footnotetext{
${ }^{63}$ Lutero vincula as ações tiranicidas na história clássica como fruto da ignorância desses povos da revelação divina, pois: "Os gentios, como nada soubessem de Deus, também não reconheceram que o regime secular é ordem de Deus (pois o consideravam destino e ação humanas); nele intervinham sem pestanejar e não somente achavam equitativo mas também louvável depor, matar e desterrar autoridades imprestáveis e malvadas. Por isso os gregos prometiam, com leis públicas, presentes e preciosidades aos tiranicidas, isto é, àqueles que esfaqueassem ou matassem um tirano. Os romanos seguiram esse exemplo amplamente em seu império assassinando eles mesmos praticamente a maioria dos seus imperadores, tanto é que neste mesmo louvável império quase nenhum imperador acabou sendo morto pelos inimigos [de fora]. Deixaram poucos deles morrer na cama ou de morte natural. [e com certo constragimento numa postura próxima àquela que encontraremos em Bèze, reconhece, talvez por seu compromisso com o princípio da Sola Scriptura, haver nas escrituras narrativas de tiranicídios, porém se recusa a comentá-las mais amplamente como fez com os casos extraídos do mundo clássico]. Da mesma forma os povos de Israel e Judá também mataram e assassinaram alguns de seus reis." LUTERO, Martinho. Acerca da questão, se também militares ocupam uma função bem-aventurada. In: Martinho Lutero: Obras selecionadas. v. 6. São Leopoldo: Comissão Interluterana de Literatura, 1995, p. 373. ${ }^{64}$ LUTERO, Martinho. Op. cit., p. 380.
} 
moral, e devem ser interpretados como meras recomendações. Qualquer atitude contrária a passividade seria se apoderar de uma prerrogativa somente pertencente a Deus: a de punir os maus governantes, salvo a existência de uma autoridade competente entre governado e governante, que pudesse julgar, com equidistância, a reivindicação daquele que se diz oprimido. Todavia, Lutero silencia e nem desenvolve essa sua indicação, sugerindo em última análise sua inexistência, do contrário, ocorreria tão somente uma censurável sedição do súdito.

Porém, apesar de todo tom de prudência coerente com os demais escritos de Lutero, na obra de 1526, com a temática do ofício dos militares, Lutero abre uma pequena brecha ao direito de resistência, limitadíssimo a um simples não obedecer, ou seja, não concretizar o ato exigido do governante, mas também nunca reagir ativamente, suportando as consequências, que configurariam verdadeiras penalidades a serem impostas por tal atitude.

Tal recomendação é pautada na exortação bíblica de Atos 5, 29. Ao relatar a hipótese de o governante a quem se deve servir em seus corpos de tropas regulares não estar com razão ao entrar em guerra, assim descreve a boa conduta do cristão nesse caso: "Se souberes com certeza que ele não está com a razão [a dúvida para Lutero beneficia o governante, devendo o súdito executar seus comandos], então deves temer e obedecer a Deus mais que a pessoas humanas (Atos 5.29), não devendo servir nem ir à guerra; pois então não poderás ter boa consciência perante Deus. Mas - dirás - meu senhor me obriga, toma, tira-me a vida, não me dá meu dinheiro, nem soldo, nem recompensa; além disso eu seria desprezado, envergonhado diante do mundo como covarde, sim, como infiel que abandona seu senhor na hora do aperto [...]"65

Em suma, afere-se em Lutero a inexistência de qualquer forma de contrato social ou político que forneça subsídios para que se vislumbre uma reciprocidade entre governante e seu povo, sendo a autoridade meramente adquirida por simples delegação divina. ${ }^{66}$

Porém, conforme adverte David M. Whitford, não se pode considerar Lutero "nem o ogro do governo ilimitado e da tirania, nem um espírito liberal do Iluminismo democrático", mas apenas um pensador que se insere no limite das eras medieval e moderna e, sob uma perspectiva de nossa contemporaneidade, sua visão sobre a vida civil seria

\footnotetext{
${ }^{65}$ LUTERO, Martinho. Acerca da questão, se também militares ocupam uma função bem-aventurada. In: Martinho Lutero: Obras selecionadas. v. 6. São Leopoldo: Comissão Interluterana de Literatura, 1995, p. 395. ${ }^{66}$ MESNARD, Pierre. L'essor de la Philosophie Politique au XVI Siècle. Paris: Libraire Philosophique J. Vrin, 1977, p. 226.
} 
extremamente conservadora, "mas isso faz dela não menos revolucionária em seu próprio tempo." 67

Apenas o máximo que se apresenta em sua biografia, no sentido de um maior arrojo permissivo ao direito de resistência ativa, seria uma capitulação autorizadora do direito de resistência no palácio de Torgau, nos fins de outubro de 1530, que analisaremos adiante juntamente com outros autores luteranos, até pelo fato de tal escrito ter sido redigido de próprio punho pelo reformador, e também assinado por outras lideranças luteranas que, segundo Pierre Mesnard, teriam, juntamente com as circunstâncias vividas pelo movimento reformador alemão, extorquido tal declaração de Lutero ${ }^{68}$.

Apesar do evento supra citado, o interpretamos mais como uma atitude política de Lutero do que propriamente uma elaboração teórica componente do conjunto de sua obra, permitindo a afirmação de haver ao longo do projeto reformador do teólogo de Wittenberg, que não envolvia apenas elocubrações teóricas, mas também atitudes políticas, um quase nulo grau de adesão ao direito de resistência.

\section{4 $O$ argumento constitucional em Calvino a título de ambígua especulação}

Calvino, conforme foi anteriormente afirmado, possui um projeto político ${ }^{69}$, no bojo de sua teologia, em larga medida próximo ao de Lutero, pelas qualificações de se tratar de uma reforma magisterial e de reafirmação do rechaço absoluto das teses da reforma radical.

Para compreensão do pensamento político de Calvino, deve-se expor três partes de seu clássico para a teologia protestante: A Instituição da Religião Cristã, a Dedicatória a Francisco I, o capítulo X do livro III: Como se deve usar da presente vida e de seus recursos e principalmente o capítulo XX do livro IV: O poder civil.

O reformador inicia sua obra seguindo a tradição dos reformadores magisteriais, expondo formalmente sua absoluta submissão aos poderes constituídos, como pôde ser observado anteriormente na dedicatória de Lutero ao eleitor da Saxônia, na obra: Sobre a

67 WHITFORD, David M. Luther's political encounters In: McKIM, Donald K. (org.). The Cambridge Companion to Martin Luther. Cambridge: Cambridge University Press, 2003, p. 190.

68 MESNARD, Pierre. L'essor de la Philosophie Politique au XVI Siècle. Paris: Libraire Philosophique J. Vrin, 1977, p. 228.

69 A expressão projeto político na certa apresenta um uso mais feliz na obra de Calvino do que na de Lutero. 
Autoridade Secular, ao designar, em sua dedicatória a Francisco I: "ao Potentíssimo e Ilustríssimo Monarca Francisco, Rei Cristianíssimo dos Franceses, Seu Príncipe, João Calvino suplica a paz e a saúde em Cristo." 70

Além das primeiras palavras de submissão, que ornam o frontispício da Dedicatória, sistematicamente Calvino registra, no decorrer do texto, a distância em relação à Reforma Radical, numa tentativa de refutar previamente qualquer vinculação de seu pensamento teológico ou político com o dos anabatistas, conforme se lê:

\begin{abstract}
De fato, se houver alguns que causam tumultos sob o pretexto do Evangelho (dos quais até agora não averiguado haver em vosso reino), se houver alguns que têm a liberdade da graça de Deus como pretexto para a licenciosidade de seus vícios (muitos dos quais conheci), há leis e as penas da lei pelas quais sejam asperamente refreados segundo os merecimentos: tão-só para que, nesse meio-tempo, o Evangelho de Deus não seja mal reputado em consequência da maldade dos homens celerados. ${ }^{71}$
\end{abstract}

Calvino institui, no capítulo X, do Livro III, a necessidade de se encarar os dons espirituais e materiais com frugalidade e prazer, além de censurar, nessa mesma oportunidade, falsas verdades evangélicas de privações exageradas, conforme expressa o subtítulo 2 do presente capítulo: "O princípio correto, no uso das coisas, é servirmo-nos delas de acordo com sua finalidade, e na medida à qual se destinam, e usá-las de acordo com a necessidade que temos delas e conforme o deleite que nos proporcionam." ${ }^{\text {72 }}$. Por fim, enfatiza a exortação no primeiro parágrafo do subtítulo: "Este é o princípio: o uso dos dons de Deus não aberra quando se ajusta aos fins para os quais o próprio Criador nos criou e destinou esses dons, porque foi para o nosso benefício, não para o nosso dano, que Ele os criou. Por isso, ninguém mais segurará o caminho reto senão aquele que atentar diligentemente para esse fim."73 , descrição genérica sobre a utilidade das coisas do mundo, com repercussões na compreensão sobre a possibilidade de existir licitamente meios de controle dos governantes, que possam ser utilizados, conforme adiante afirmará o reformador ao tratar da temática das vocações.

\footnotetext{
${ }^{70}$ CALVINO, João. A Instituição da Religião Cristã. São Paulo: Editora Unesp, 2007, p.13.

${ }^{71}$ Ibidem, p.33.

${ }^{72}$ CALVINO, João. Poder Civil. In: BONI, Alberto de (org.). Escritos Seletos de Martinho Lutero Tomás Müntzer e João Calvino. Petrópolis: Vozes, 2000, p. 231.

${ }^{73}$ Ibidem, p. 231.
} 
Posto esse pano de fundo, Calvino descreve um dos conceitos fundamentais para sua teologia, e com decisivas repercussões em sua teoria política, com ampla acolhida por calvinistas como Bèze, por sua profunda compatibilidade com as teorias políticas seculares ${ }^{74}$, que é seu conceito de vocação.

Calvino define vocação como modalidade de viver; "para que através de nossa estultícia e temeridade não se misturem todas as coisas de cima para baixo, Deus ordenou a cada um os seus deveres, em diferentes gêneros de vida. E para que ninguém ultrapassasse, temerariamente, os seus limites. [...] Portanto, para que os homens não sejam levados, às cegas, ao leu, por todo o curso de sua vida, o Senhor atribuiu a cada um sua força de viver, como se fora um posto de serviço."75, ou seja, a vocação para Calvino seria, em última análise, ao mesmo tempo manifestação e garantia da boa ordenação do mundo.

Após instituir os ditames gerais de sua ideia de vocação, o autor não se furta a consignar, em termos comparativos, a especificidade das distintas funções dos agentes públicos (magistrados) e dos particulares (chefe-de-família), vocações ou categorias fundamentais para demarcar os diferenciados limites de atuação de um magistrado e de um particular diante de uma tirania, na elaboração futura do constitucionalismo calvinista de resistência, sobretudo em Bèze, pois conforme Calvino assevera: "o magistrado desempenhará suas funções de melhor grado e o chefe-de-família se restringirá ao seu dever, e cada um, em seu gênero de vida, suportará e absorverá as desvantagens, as preocupações, os aborrecimentos e as angústias, quando se persuadir de que o fardo de cada um foi imposto por Deus. Contudo, insigne consolação advirá desde que obedeçamos à nossa vocação, pois nenhuma obra haverá, diante de Deus, tão ignóbil e vil, que não resplandeça e não seja tida por valiosíssima."

No capítulo $\mathrm{XX}$ do livro $\mathrm{IV}^{77}$, O poder civil, conforme indica o próprio nome, encontra-se o ápice da sistematização das ideias políticas do pensamento de Calvino, que

\footnotetext{
${ }^{74}$ Como a origem do argumento constitucional de resistência nos estudos de Filipe de Hesse e seus juristas nos meses finais de 1529, em razão das manobras de Carlos V na Dieta de Speyer, gerando uma das maiores crises para a sobrevivência do movimento reformador, de tal modo que se passa a exigir um discurso legitimador da resistência ativa. SKINNER, Quentin. As fundações do pensamento político. São Paulo: Cia das Letras, 2000, p. 473-474.

${ }^{75}$ CALVINO, João. Poder Civil. In: BONI, Alberto de (org.). Escritos Seletos de Martinho Lutero Tomás Müntzer e João Calvino. Petrópolis: Vozes, 2000, p. 235.

${ }^{76}$ Ibidem, p. 236.

${ }^{77}$ Henri Strohl salienta a justificativa de Calvino tratar com maior atenção a questão do poder político ao longo de seu percurso teológico, ao incorporar o capítulo ao tratado posteriormente às primeiras edições $(1536,1539$, $1545,1550,1553$ e 1554) sob o peculiar título atribuído pelo autor ao Livro VI das Instituições: "É significativo, para se compreender o pensamento de Calvino, que o capítulo sobre o governo civil - até 1554 um capítulo à parte - tenha sido incorporado, em 1559, na edição definitiva da IRC, no livro IV que tem o título Meios e instrumentos externos de que Deus se utiliza para conduzir-nos a Jesus Cristo e nele preservar-nos. $O$
} 
ficam tensionadas entre o repúdio aos reformadores radicais e a ojeriza aos bajuladores dos príncipes que possuem um discurso franqueador da ilimitabilidade do poder dos governantes, o que denuncia em sua escrita uma forte sensibilidade à conjuntura política de seu tempo: "E sobretudo porque, nos dias de hoje, existem homens tão obstinados e bárbaros, que fazem todo o possível para destruir esta ordenação que Deus estabeleceu. E, por outro lado, os aduladores dos príncipes, ao engrandecer sem limite nem medida o seu poder, não duvidam em colocá-los em competição com Deus. Desse modo, se não se aplicar um corretivo em tempo a uns e outros, decairá a pureza da fé."

Reafirmando a natureza de um projeto de reforma magisterial, e a desautorização de qualquer interpretação bíblica que implique o desprezo pela ordem civil manifesta por leis e seus respectivos magistrados, Calvino exalta por meio de fundamentos bíblicos a essência da condição dos magistrados: "No que concerne à condição dos magistrados, o Senhor não apenas declarou que essa condição lhe é aceita e grata; porém, ainda mais a honrou com títulos ilustres e honoríficos, e nos tem recomendado singularmente sua dignidade. Para provar isso brevemente, vejamos: aqueles que estão constituídos em dignidade e autoridade são chamados 'deuses' (Ex 22, 8-9; S1 82, 1.6). Esse é um título que não se deve estimar pouca coisa; com ele se mostra que os magistrados têm mandato de Deus, que são autorizados e entronizados por Ele e em tudo representam sua pessoa, sendo, de certo modo, seus substitutos."79 , o que leva à categórica conclusão contrária aos reformadores radicais: "Portanto, não se deve pôr em dúvida que o poder civil é uma vocação, não somente santa e legítima diante de Deus, mas também mui sacrossanta e honrosa entre todas as vocações."

Após as elogiosas afirmações sobre a legitimidade do exercício do poder civil perante Deus e sua respectiva contribuição para boa ordenação do mundo, Calvino desloca sua argumentação para confrontar os bajuladores dos governantes que os consideram como não condicionados a quaisquer freios. Ele introduz, pela própria consideração que Deus possui pelos magistrados, um elemento de responsabilidade teológica na atuação dos governantes: "Em suma, se [os magistrados] têm consciência de que julgam em lugar de Deus, deverão empregar toda sua diligência e empenhar todo o seu esforço em oferecer aos homens, enquanto julgarem, certa imagem da providência divina, da proteção, da bondade, da

governo civil é, pois um desses instrumentos". (STROHL, Henri. O Pensamento da Reforma. São Paulo: ASTE, 1963, p. 233).

${ }^{78}$ CALVINO, João. Poder Civil. In: BONI, Alberto de (org.). Escritos Seletos de Martinho Lutero Tomás Müntzer e João Calvino. Petrópolis: Vozes, 2000, p. 237-238.

${ }^{79}$ Ibidem, p. 241.

${ }^{80}$ Ibidem, p. 242. 
doçura e da justiça de Deus" ${ }^{\text {81 }}$ e, justamente em razão desses encargos, Calvino alerta que: "Em outro lugar está escrito que 'Deus assiste na congregação divina e no meio dos deuses

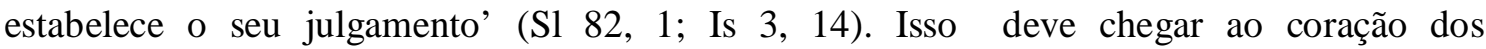
magistrados, pois com isto se lhes ensina que são lugares-tenentes de Deus, a quem hão de prestar conta do cargo que desempenham. E certamente com toda razão, esta advertência os deve estimular porque, se são faltosos em alguma coisa, não fazem agravo apenas aos homens - aos quais atormentam injustamente - mas também a Deus, manchando seus sagrados juízos." 82

Outro ponto apresentado por Calvino, no que tange ao controle dos governantes, está na sua discussão sobre a melhor forma de governo. Porém, nessa oportunidade, parte de pressupostos do pensamento político secular da tradição da Antiguidade Clássica, ao classificar as formas de governo em: monarquia, aristocracia e democracia. Elege a aristocracia, quer pura ou com elementos democratizantes, como a melhor, não por um mérito inerente a tal forma, mas mais ainda pelos deméritos das outras, que tão facilmente tendem a se degenerar, uma vez que a pluralidade, ainda que pequena, existente numa aristocracia permitiria um mecanismo de freios intrínseco a tal espécie de governo, de modo que se qualquer uma das pessoas com poderes de comando atribuir a si um plus de poder que não lhe é devido, as outras prontamente estão aptas a corrigir o erro:

Admito de imediato que, se as três formas de governo a que se referem os filósofos forem consideradas em si mesmas, a aristocracia, seja em sua forma pura, seja em uma forma mista, combinando a aristocracia e o governo constitucional ${ }^{83}$, excederá em muito todas as demais formas. Isso não acontece por aquela forma ser inerentemente superior, mas [antes] porque é muito raro que os reis exerçam um autocontrole tal que sua vontade jamais se afaste daquilo que é justo e direito. E é igualmente raro que os reis sejam dotados de uma ponderação e sagacidade de compreensão tais que

\footnotetext{
${ }^{81}$ CALVINO, João. Poder Civil. In: BONI, Alberto de (org.). Escritos Seletos de Martinho Lutero Tomás Müntzer e João Calvino. Petrópolis: Vozes, 2000, p. 243.

${ }^{82}$ Ibidem, p. 244.

${ }^{83}$ Em nota, Harro Höpfl explica o que se deve entender com a expressão governo constitucional: "Calvino está aqui empregando o termo aristotélico politeia em sua versão latina. Em sua Política (Livro 4, capítulo 2), Aristóteles distinguiu entre duas formas de governo de cidadãos, uma forma corrompida, a que chamou "democracia", e outra incorrupta, uma espécie de governo "legal" ou "constitucional", a que chamou de "ordem constitucional", "governo constitucional". Os escritores escolásticos nem sempre se deram o trabalho de fazer essa distinção e em geral usaram indiscriminadamente o termo "democracia" para todas as formas de governo do povo. Deve-se observar que o próprio Calvino segue essa prática na versão francesa." (HÖPFL, Harro. nota 31. In: CALVINO, João. Lutero e Calvino, Sobre a Autoridade Secular. São Paulo: Martins Fontes, 2005, p. 86.
} 
sejam [sempre] capazes de discernir aquilo que é bom e proveitoso. Portanto, são os vícios e imperfeições da humanidade que tornam mais seguro e mais tolerável que várias pessoas governem [em conjunto], todas auxiliando, instruindo e admoestando umas às outras; de tal modo que, se alguma delas atribuir indevidamente a si mais do que está autorizada a fazer, haverá outras para intervir censurando-a, e dominando-a, de modo que refreie sua indisciplina. $^{84}$

Além do mais, após recorrer preliminarmente à autoridade secular, Calvino alerta que Deus também confirma tal forma de governo entre os israelitas, que viviam sob "uma aristocracia limítrofe ao governo constitucional ${ }^{85}$

Ainda nesse contexto de discussão sobre a melhor forma de governo dentro da Instituição, Calvino acolhe nesse tópico argumentativo, em termos genéricos $\mathrm{e}$ universalmente válidos, "o argumento constitucional de resistência política pela via das magistraturas inferiores", que posteriormente seria exaustivamente analisado, expandido e consolidado por Théodore de Bèze, na obra Du droit des magistrats, ao afirmar o sucessor de Farel nos primórdios da reforma genebrina:

Admito de bom grado que nenhuma forma de governo é melhor do que aquela na qual estão reconciliados a liberdade e o grau correto de coerção, [um governo] corretamente ordenado de modo que seja duradouro [...]. Consequentemente, considero os mais afortunados aqueles que têm permissão de gozar de tal condição; e, se eles sempre fizerem o máximo possível para protegê-la e conservá-la, julgo que isso não é mais do que seu dever. E, mais importante ainda, os magistrados [sob essa forma de governo] devem envidar todos os esforços para impedir qualquer diminuição e, ainda pior, qualquer violação daquela liberdade da qual foram apontados guardiões. Se forem indolentes ou descuidados em relação a esse ponto, serão traidores de seu cargo e região. ${ }^{86}$

Em outro movimento do discurso, numa dinâmica pendular de argumentação, Calvino aparenta alocar seu posicionamento no pólo da submissão, ao alegar que em todo o mundo se aferem distintas formas de governo, oriundas da providência, cabendo aos homens

\footnotetext{
${ }_{85}^{84}$ CALVINO, João. Lutero e Calvino, Sobre a Autoridade Secular. São Paulo: Martins Fontes, 2005, p. 86.

${ }^{85}$ Ibidem, p. 87.

${ }^{86}$ Ibidem, p. 87.
} 
não maiores especulações, apenas a submissão, apesar de anteriormente consignar sua predileção pela aristocracia e suas variações, conforme se lê: "Porque se é Sua vontade constituir reis sobre reinos - e sobre repúblicas outra autoridade -, nosso dever é submeternos e obedecer aos superiores que dominam no lugar onde vivemos." ${ }^{\text {,7 }}$

Por fim, Calvino, ao considerar sua interpretação das vocações e seus desdobramentos no plano político quanto às pessoas privadas, estabelece, em um tom pedagógico na forma e luterano no conteúdo, que a vingança contra tiranias é uma prerrogativa de Deus, não cabendo-lhes executá-la ${ }^{88}$. Porém especula prudentemente a respeito de uma outra vocação, a dos magistrados inferiores, que estariam licitamente autorizados por fundamentos seculares e bíblicos a resistirem aos tiranos que surjam em suas respectivas épocas e circunstâncias geográficas, afirmando que:

Pode ser que existam em nossos dias magistrados populares instituídos para conter a licenciosidade dos reis, correspondentes àqueles "Éforos", firmemente contrários à autoridade dos reis espartanos, ou os Tribunos do Povo, colocados acima e em contraposição aos cônsules romanos, ou os 'Demarcas', levantados em oposição ao Conselho dos atenienses. E talvez, nas atuais circunstâncias, seja da mesma natureza a autoridade exercida pelos três estados em reinos específicos, quando eles realizam suas principais assembleias. Se existirem [magistrados do povo estabelecidos], não é parte de minhas intenções proibi-los de agir em conformidade com seu dever e de resistir à licenciosidade e ao furor dos reis; ao contrário, se eles forem coniventes com a violência desenfreada [dos reis] e suas ofensas contra as pessoas pobres em geral, direi que uma tal negligência constitui uma infame traição de seu juramento. Eles estão traindo o povo e lesando-o naquela liberdade cuja defesa sabem ter-lhes sido ordenada por Deus. ${ }^{89}$

Em termos conclusivos, pode-se afirmar que Calvino, em sua prudência quanto à possibilidade de resistir aos governos tiranos, vale-se de um estilo sinuoso, serpenteando a divisa dos caminhos da obediência irrestrita com um conteúdo quase luterano e o da resistência constitucional, que se apresenta prudentemente a título especulativo com a possibilidade (manifesta nas expressões pode ser, talvez e Se existirem) de ser lícita a

${ }^{87}$ CALVINO, João. Poder Civil. In: BONI, Alberto de (org.). Escritos Seletos de Martinho Lutero Tomás Müntzer e João Calvino. Petrópolis: Vozes, 2000, p. 246.

${ }^{88}$ CALVINO, João. Lutero e Calvino, Sobre a Autoridade Secular. São Paulo: Martins Fontes, 2005, p. 128.

${ }^{89}$ Ibidem, p. 128-129. 
concretização da resistência albergada pelo argumento constitucional em seu próprio tempo: a conturbada França envolta nos conflitos religiosos, desde que suas leis fundamentais assim a permitirem, como permitiam na Grécia e Roma clássicas. Porém, a afirmação categórica, inequívoca e segura para boa consciência (numa expressão comum aos tratados monarcômacos) dos súditos cristãos, autorizadora da resistência, apenas apareceria nos tratados calvinistas de segunda geração. ${ }^{90}$

Apesar da interpretação mais literal acima apresentada, pautada nos escritos da Instituição como o ponto máximo da possibilidade da resistência ativa para Calvino pelo viés do argumento constitucional, elaborado por luteranos como resposta à crise do protestantismo na década de 1530, Skinner aponta que também de forma ambígua e de maneira mais sutil ainda Calvino acolheria em seu corpo teórico o argumento de resistência de direito privado, também elaborado por luteranos, e que seria mais radical, uma vez que franqueia um entendimento quase imediato de que o tirano, ao ser considerado como tal, pode ter o tratamento de um criminoso comum, sendo, portanto, sujeito a uma reação análoga à da legítima defesa, que potencialmente justificaria uma popularização do movimento reativo à tirania.

Tal repertório teórico encontra-se contemplado, seja nas referências de Calvino ao profeta Daniel, seja em obras autônomas ou na Instituição. Skinner assevera que:

Ao publicar a última edição latina das Institutas da religião cristã, em 1559, Calvino inseriu no capítulo final, pela primeira vez, uma só frase, muito eloquente, que parece ao menos conter uma alusão à teoria da resistência fundamentada no direito privado. O fraseado é de extrema ambiguidade (como sempre), não mencionando a ideia de que, se um governante exceder sua legítima autoridade, automaticamente se reduzirá ao estatuto de um criminoso privado. Contudo, há nessa passagem a clara sugestão de que o governanate que ultrapassa os limites de seu cargo automaticamente deixa de ser um genuíno magistrado. Calvino cita o exemplo de Daniel quando 'nega ter cometido uma ofensa contra o rei ao desobedecer a seu ímpio decreto'. O que justifica esse ato, Calvino agora se dispõe a afirmar, é 'que o rei excedeu seus limites, e não apenas foi perverso

\footnotetext{
${ }^{90}$ A razão da sinuosidade do percurso argumentativo é a constante ambiguidade encontrada nos escritos que versam sobre política na obra de Calvino, conforme explica Skinner: "Calvino, em todos os momentos, é o mestre da ambiguidade e, embora não haja dúvidas que endossa uma teoria da não-resistência, na prática introduz várias exceções em sua argumentação." (SKINNER, Quentin. As fundações do pensamento político. São Paulo: Cia das Letras, 2000, p. 468).
} 
contra os homens, mas ao erguer suas trombetas contra Deus, também abrogou seus próprios poderes'. ${ }^{91}$

Outro tópico a ser destacado, argumentativo da recepção da teoria das magistraturas como forma de combate a uma tirania, é uma presença sintomática da formação humanística de Calvino, mais evidente quando comparamos com os textos de Lutero ${ }^{92}$, o que, em certo sentido, estimula num segundo momento do movimento calvinista um aprofundamento da discussão da resistência pautada em argumentos seculares, desenvolvida, sobretudo, pelos monarcômacos, quando referenciados em relação aos textos dos luteranos, da segunda geração do movimento, mais vinculados aos fundamentos bíblicos.

Em suma, o que podemos perceber em Calvino é a reafirmação de seu status de reformador magisterial, pontuando seu texto em várias oportunidades com o rechaço aos argumentos dos reformadores radicais. Porém, apesar dessa postura, o reformador não se furta a se deixar influenciar pelas teses franqueadoras de uma resistência quer amparada no argumento constitucional, quer no direito privado, com uma prudência, que muitas vezes, se revestia de ambiguidade.

\footnotetext{
${ }^{91}$ SKINNER, Quentin. As fundações do pensamento político. São Paulo: Cia das Letras, 2000, p. 494. Outras obras apontadas por Skinner que associam considerações sobre o profeta Daniel e a recepção do argumento de resistência pautado no direito privado, que retiraria dos tiranos, a dignidade da condição de governante e, portanto, de inviolabilidade, ao se insurgirem contra Deus seriam: Prelações sobre o profeta Daniel, de 1561 e Sermões sobre os últimos oito capítulos do Livro de Daniel, de 1565. (SKINNER, Quentin. Op. Cit., p. 495). Na obra A tenência dos reis e magistrados, de John Milton encontramos uma ampla citação da obra de Calvino Prelações sobre o profeta Daniel,", na qual percebemos o tom virulento com que Calvino trata a tirania, despojando-se de sua elegante e prudente escrita humanística que encontraríamos na Instituição, numa dinâmica que aproximaria, na forma, Calvino dos textos apaixonados de Lutero. Assim Calvino diz o que merece um tirano: "Hoje em dia os monarcas sempre se pretendem em seus títulos reis pela graça de Deus. Mas quantos dentre eles têm essa pretensão apenas com a finalidade de reinarem sem controle? Com que propósito se menciona a graça de Deus no título dos reis, senão para que eles não reconheçam nenhum superior? Enquanto isso Deus, cujo nome eles usam para se defender, seria esmagado sob seus pés de bom grado. Portanto, não passa de mero embuste quando se vangloriam de reinar pela graça de Deus.

Os príncipes terrenos abdicam quando se insurgem contra Deus; mais ainda, são indignos de se contarem entre os homens. A nós compete mais cuspir em suas cabeças do que lhes obdecer." (CALVINO, João. Prelações sobre o profeta Daniel, apud MILTON, Jonh. A tendência de reis e magistrados. In: DZELZAINIS, Martin (org.). Escritos Políticos. São Paulo: Martins Fontes, 2005, p.55).

${ }^{92}$ Um exemplo fundamental do valor da cultura humanística secular no horizonte intelectual de Calvino, além de deixar referências expressas na Instituição da Fé Cristã, consiste no fato de a primeira obra publicada por ele, aos vinte e três anos, em 1532, ser uma tradução do filósofo estoico SÊNECA, De Clementia. COLLINSON, Patrick. A Reforma. Rio de Janeiro: Objetiva, 2006, p. 109.
} 


\subsection{Müntzer e a "horda sanguinária dos salteadores"}

Ainda que Müntzer tenha sido aclamado como o primeiro revolucionário do povo alemão por marxistas como Engels ${ }^{93}$ e elevado à dignidade de heroi nacional pela República Democrática Alemã, é certo que "seu agir pautou-se inegavelmente por um ideal religioso", o que excluiria suas práticas político-devocionais e seus escritos de uma interpretação com base no materialismo histórico marxista.

No bojo desse ideal religioso, Müntzer, como outros reformadores radicais, conforme foi apontado anteriormente, dispensou a colaboração dos magistrados civis para a renovação da Igreja e, não raro, os compreendem como tão apartados da verdadeira religião quanto os eclesiásticos papistas, diferentemente de Lutero e Calvino, que se dignam a dedicar obras para seus magistrados governantes, colocando-se em clara posição de subordinação, uma vez que os mesmos tinham a percepção de necessitarem dos poderes constituídos para dar concretude aos seus ideiais religiosos.

Müntzer dedicou suas obras ao próprio Cristo, como o faz em claro tom de deboche às dedicatórias de Lutero em seu Pronunciamento de Defesa Altamente Motivado, de 1524, em que se percebe uma introdução paralela e oposta a da Carta aos Príncipes ${ }^{95}$, do reformador de Wintenberg, ao escrever: “Ao altíssimo príncipe primogênito e todo-poderoso, Senhor Jesus Cristo, o bondoso rei de todos os reis, meu clementíssimo Senhor e fiel protetor e à sua única e aflita, a pobre cristandade" 96 . Ou ainda, no frontispício de seu Manifesto de Praga de 1521, rememora o legado de um proto-reformador, vítima das autoridades eclesiásticas em conluio com as civis, o "estimado e santo batalhador João Hus"97.

Neste manifesto, Müntzer esclarece seu posicionamento de supremacia de uma espiritualidade garantidora da eleição, pela experiência direta com o espírito de Deus, uma vez que "esse espírito é o único alvo e fundamento dos eleitos.". De tal modo, aponta uma primeira cisão com os reformadores clássicos, ao zombar de seu princípio da Sola Scriptura e de sua ojeriza por revelações espirituais, como as pregadas por Müntzer, valendo-se da autoridade do profeta Jeremias (23:16) que alega o pouco valor, quando não a deturpação da escritura sem o bafejo do Espírito, e assim destrata os expoentes da Reforma Clássica:

\footnotetext{
${ }^{93}$ BONI, Alberto de (org.). Escritos Seletos de Martinho Lutero Tomás Müntzer e João Calvino. Petrópolis: Vozes, 2000, p. 30.

${ }^{94}$ Ibidem, p. 35.

95 Ibidem, p. 206, nota 4.

${ }^{96}$ MÜNTZER, Tomás. Pronunciamento de Defesa Altamente Motivado. In: BONI, Alberto de (org.). Escritos Seletos de Martinho Lutero Tomás Müntzer e João Calvino. Petrópolis: Vozes, 2000, p. 205-206.

${ }^{97}$ Ibidem, p. 175.
} 
"Muitas vezes e repetidamente tenho ouvido deles nada mais do que simplesmente a Escritura, a qual furtam maliciosamente da Bíblia, como ladrões pérfidos e assassinos crueis." 98

Outro ponto de distanciamento entre Müntzer e Lutero, ou qualquer outro reformador magisterial, consiste na instituição da possibilidade de o povo autonomamente tomar as rédeas do governo civil caso se verifique que este não comunga de sua renovação evangélica, conforme deixa claro em seu escrito sobre o profeta Daniel de 1524:

Da mesma maneira também é necessária a espada para extirpar os ímpios $(\mathrm{Rm} 13,4)$. Mas para que isto se efetue de modo sério e objetivo, devem fazê-lo os nossos caros pais, os príncipes que confessem Cristo conosco. Porém, onde não fazem isto, ser-lhes-á tomada a espada (Dn 7,27), pois então o confessem com palavras e o negam pela ação (Tt 1). [...] Mas com o piedoso Daniel rogo por eles, para que não sejam contrários à revelação de Deus.[manifestada pelo Espírito]. Se, porém, praticarem o contrário, [os príncipes ou clérigos] deverão ser estrangulados sem piedade, como Ezequias, Josias, Ciro, Daniel e Elias (3Rs [=1Rs] 18,40) estrangularam os sacerdotes de Baal. De outra maneira a Igreja cristã não pode retornar à sua origem. $^{99}$

Em seu Pronunciamento de Defesa altamente Motivado, Müntzer defende-se de Lutero (“o carne de vida folgada em Wittenberg" ou ainda "o companheiro domesticado") quanto à acusação de estar fomentando rebeliões, fundamentando a defesa a partir da própria escritura $^{100}$ tão afeita a Lutero. Alega que uma comunidade possui tanto o poder da espada dos governates como "a chave da sua destituição", sendo "os príncipes não senhores, porém servos da espada", não lhes sendo facultado agir ao seu bel prazer, "mas sim corretamente". 101

Para reforçar sua concepção de participação popular ativa e fiscalizatória dos que exercem os poderes civis, Müntzer recorda exortações bíblicas do Antigo Testamento, como “o antigo costume, [em que] o povo deve estar presente quando alguém é julgado justamente

\footnotetext{
${ }^{98}$ MÜNTZER, Tomás. Pronunciamento de Defesa Altamente Motivado. In: BONI, Alberto de (org.). Escritos Seletos de Martinho Lutero Tomás Müntzer e João Calvino. Petrópolis: Vozes, 2000 , p. 176.

${ }^{99}$ Ibidem, p. 203.

${ }^{100}$ Müntzer alega embasar-se em Dn 7,27; Ap 6,15; Rm 13, 1; Sm 8,7. Em seu escrito de 1525, Contra as Hordas Salteadoras e Assassinas dos Camponeses, Lutero vale-se de expressões no mínimo nada cordiais contra Müntzes e seus seguidores.

${ }^{101}$ MÜNTZER, Tomás. Manifesto de Praga. In: BONI, Alberto de (org.). Op.cit., p. 211-212.
} 
conforme a lei de Deus (Nm 15,35). Ora, por quê? Caso a autoridade fosse falsificar a sentença (Is 10, 1s), os cristãos circunstantes devem impedi-la, pois Deus quer satisfação do sangue inocente $(\mathrm{Sl} 79,10) ., 102$

Assim, com traços de rebeldia ao status quo, mas com um profundo sentimento religioso (o que descartaria qualquer antecipação de Marxismo em pleno século XVI), Müntzer condiciona o respeito às autoridades constituídas, na exata medida que elas tenham aderido a suas verdades evangélicas, mais pautadas pela particularidade da carência de se experimentar individualmente o Espírito de Deus do que pela observação estrita da Palavra, além de ter legado para a posteridade um constante esforço de denúncia da postura de subserviência dos reformadores magisteriais aos seus senhores, bem como o alijamento do povo, excluído por estes últimos de qualquer participação direta na vida civil de suas respectivas comunidades.

\subsection{A solidez de adesão de luteranos e calvinistas ao constitucionalismo de resistência a partir de 1530}

Q. Skinner, ao inventariar o desenvolvimento das ideias políticas forjadas pela Reforma Protestante, aponta os anos do raiar da década de 1530 como decisivos para elaboração de argumentos que licitamente franqueassem a resistência política. No ano de 1529, Carlos V convoca na cidade de Speyer, uma Dieta Imperial, impondo a exigência de se revogarem todas as concessões feitas aos luteranos até então; a maioria católica redige uma resolução que determina, ainda que à força, a imediata vigência do Edito de Worms, que declarava ilegal a heresia luterana. Os luteranos protestam formalmente ${ }^{103}$, "em nome de seis príncipes e catorze cidades, inspirados por João da Saxônia, Jorge de Bradenburgo-Ansbach e o jovem Filipe de Hesse, que nessa ocasião se destacou como o mais militante entre os príncipes luteranos." 104

${ }^{102}$ MÜNTZER, Tomás. Pronunciamento de Defesa Altamente Motivado. In: BONI, Alberto de (org.). Op. cit., p. 212.

${ }^{103}$ Ocasião, segundo Skinner, em que se forjou a expressão protestantismo. SKINNER, Quentin. As fundações do pensamento político. São Paulo: Cia das Letras, 2000, p. 471.

${ }^{104}$ SKINNER, Quentin. Op. cit., p. 471. 
Felipe de Hesse, debatendo o problema com vários juristas, sobretudo os de sua região (Hesse), sintetiza a possibilidade de uma resistência ativa, por meio de uma "engenhosa reafirmação da teoria feudal e particularista da constituição imperial - com base na qual [...] os eleitores já haviam resistido ao imperador Wezel, depondo-o em 1400.""105

Com esse expediente de um pensamento "constitucional" haveria a conciliação entre a resistência armada contra o imperador e o preceito luterano fundamental, derivado da exortação paulina aos romanos de que todas as autoridades foram estabelecidas por Deus. ${ }^{106}$

Em cartas de dezembro de 1529 para os dois outros soberanos magistrados protestantes que já haviam se destacado na Dieta Imperial acima referida, "o eleitor da Saxônia e o margrave de Bradenburgo-Anbach”, Felipe de Hesse passa a afirmar que Paulo, em sua exortação aos romanos, referia-se a todos os soberanos territoriais, tanto os que exercem sua jurisdição sobre um império ou um reino. Além disso, tais poderes foram ordenados com a finalidade de "desempenhar uma determinada função, na qual se inclui o dever de observar algumas obrigações legais mútuas, bem como o de garantir o bem-estar e a salvação de seus próprios súditos."107

Para Filipe de Hesse a relação jurídica entre o imperador e os príncipes não consistia na relação entre governante e governado, mas sim a de detentores de autoridades com imperium que, como tais, podiam licitamente se opor aos rompimentos de tratados firmados com outras autoridades também soberanas. "Assim, a conclusão é que, se o imperador ultrapassar os limites de seu cargo perseguindo o Evangelho ou tratando com violência qualquer um dos príncipes, estará violando as obrigações a ele impostas por ocasião de sua eleição, sendo, portanto, legítimo combatê-lo."108

O eleitor da Saxônia, ao acionar Lutero sobre o conteúdo da carta de Hesse, recebe como resposta do reformador alemão a afirmação de ser o imperador superior aos príncipes, como também que, se o imperador agisse de forma contrária ao evangelho, nada poderia ser feito para aplacá-lo "em sã consciência". 109

Apesar dessa cautela do patriarca da reforma alemã em 1530, depois de uma Dieta em que Carlos V manda refutar as teses apresentadas por Melanchton na Confissão de Augsburgo, que aspirava a uma concórdia com os católicos, a maioria católica presente na Dieta impõe a resolução de que todos os hereges luteranos retornem à unidade cristã até a

\footnotetext{
${ }^{105}$ SKINNER, Quentin. As fundações do pensamento político. São Paulo: Cia das Letras, 2000, p. 471.

${ }^{106}$ Ibidem, p. 471.

${ }^{107}$ Ibidem, p. 471-472.

${ }^{108}$ Ibidem, p. 472.

${ }^{109}$ Ibidem, p. 472.
} 
próxima Páscoa e impõe a suspensão das pregações de conteúdo luterano. Além disso, ao fim da assembleia, acorda-se "entre os príncipes católicos a formação de uma liga de defesa do império, medida que deliberadamente impunha uma ameaça militar direta aos protestantes." 110

Diante da possibilidade de um futuro sombrio para a causa protestante alemã, Filipe de Hesse escreve em outubro de 1530 para Lutero, como também a João da Saxônia e a seu chanceler Gregory Brück, “exortando-os a aceitar seu plano para uma aliança protestante e pedindo-lhes que aceitassem seu pressuposto de que na verdade era possível justificar a resistência armada ao imperador."111

Após essa nova exortação de Filipe de Hesse, o eleitor da Saxônia sensibiliza-se diante da crise enfrentada por sua nova fé e decide consultar Brück e seus demais juristas quanto à viabilidade ou não da licitude das ideias de Filipe. No final de outubro de 1530 , Brück e seus auxiliares entregam ao eleitor da Saxônia a súmula: Se é justo defender-se de um juiz que procede injustamente. Em tal documento, apesar da intenção desses juristas da Saxônia em aceitar a "interpretação federalista da constituição imperial" elaborada por Hesse e seus homens de leis, percebe-se que Brück e seus colegas optaram por fundamentar o direito de resistência ativo pelo viés do direito privado, segundo o qual, em certas circunstâncias "o uso da violência não constitui necessariamente uma injúria”, tese já aventada por civilistas e canonistas, em que se declara "ser justificável repelir com força a força injusta". ${ }^{112}$

Valendo-se de canonistas como Panormitanus, cuja tese era de ser possível licitamente resistir a um juiz injusto, e ao insistir "em que o estatuto do imperador era com efeito o de um juiz", Brück, tornava perfeitamente aplicável ao caso concreto as lições de Panormitanus.

Em sua súmula, Brück caprichosamente "deu uma resposta em termos gerais [ao seu soberano da Saxônia], com copiosas citações do direito canônico - escolhidas, talvez, com o intuito de condenar os imperialistas, usando argumentos de autores impecavelmente católicos, cuja autoridade teria muita dificuldade para refutar."113

$\mathrm{Na}$ súmula ora referida, Brück desenvolve a argumentação expondo três possibilidades de resistência violenta a um juiz quando ocorre uma apelação: havendo o juiz

\footnotetext{
${ }^{110}$ SKINNER, Quentin. As fundações do pensamento político. São Paulo: Cia das Letras, 2000, p. 473.

${ }^{111}$ Ibidem, p. 473.

${ }^{112}$ BRÜCK, Gregory. Se é justo defender-se de um juiz que procede injustamente, p. 63-65, apud SKINNER, Quentin. As fundações do pensamento político. São Paulo: Cia das Letras, 2000, p. 473-474.

${ }^{113}$ Ibidem, p. 474. Tal expediente, de utilizar-se argumentos genuinamente católicos em seus tratados também seria utilizado, conforme veremos, por calvinistas, sobretudo a autoridade dos conciliaristas.
} 
decidido fora de sua jurisdição, causando uma injúria notória e irreparável; e uma última possibilidade: "se o juiz age de acordo com a sua jurisdição, porém injustamente, e se o dano for irreparável",114

$\mathrm{Na}$ percepção de Brück, sobretudo quanto aos dois últimos casos, nessas circunstâncias, o juiz não estaria mais "agindo como um juiz no caso em questão, mas apenas como um indivíduo privado." ${ }^{115}$ Dessa forma, restaria lícito, como o é, reagir e defender-se contra qualquer pessoa privada que perpetra uma violência injusta contra alguém. ${ }^{116}$

À luz dessas construções teóricas, o jurista saxão analisa concretamente o caso das atitudes de intolerância do imperador, que tanto afligia os luteranos depois de Dieta de 1530. Para Brück, o imperador, que é comparável a um juiz, estaria incorrendo nas hipóteses acima mencionadas, que autorizam a resistência, e poderia ser tratado como um particular e não mais como homem público, pois dispõe de um assunto cujo conteúdo não pertence a sua jurisdição (questões de fé) e seu agir é de notória injustiça. Além do mais, já estava em sede de apelação a causa luterana, uma vez que "os príncipes e as cidades estão apelando não somente ao imperador, mas a um concílio geral da Igreja."117

Dessa forma, em fins de 1530, os luteranos possuíam duas construções teóricojurídicas que chancelavam a resistência ativa ${ }^{118}$, e pressionados pelas circunstâncias que viviam, capitulam em seus escrúpulos de não resistirem. Tal capitulação pode inclusive ser datada entre os dias 25 e 28 de outubro, quando no Palácio de Torgau, João da Saxônia convoca juristas e teólogos para debaterem o conteúdo da súmula de Brück. Ao final, Lutero “redige de próprio punho uma capitulação formal", também assinado por Melanchton, Jonas e Spalatin.

Nessa ocasião, Skinner aponta que, apesar de estar disponível a construção teórica de Hesse, mais prudente pelo seu conteúdo constitucional, nos fins de outubro de 1530, os luteranos teriam aderido mais especificamente ao argumento de Brück, pautado no direito privado e, portanto, mais radical.

Tais teólogos declaram que o problema da resistência fora sanado pelos juristas, e que apesar de "até agora termos ensinado a não resistir em absoluto à autoridade do governo",

\footnotetext{
${ }^{114}$ BRÜCK, Gregory. Se é justo defender-se de um juiz que procede injustamente, p. 63-65, apud SKINNER, Quentin. As fundações do pensamento político. São Paulo: Cia das Letras, 2000, p. 474.

${ }^{115}$ Ibidem, p. 474.

${ }^{116}$ SKINNER, Quentin. As fundações do pensamento político. São Paulo: Cia das Letras, 2000, p. 474.

${ }^{117}$ BRÜCK, Gregory. Op. cit., p. 474.

118 Os argumentos de resistência, queira pautados no direito privado dos juristas da Saxônia, queira no constitucionalismo dos juristas de Hesse, encontrarão amplo eco e desenvolvimento nos calvinistas insulares (Knox, Ponet e Goodman) o argumento de direito privado e nos continentais (Hotman, Bèza e Mornay) o constitucional.
} 
"seguramente estamos naquelas situações em [...] [que] se pode resistir à autoridade do governo", pois "não sabíamos que a própria lei da autoridade dirigente admite o direito da resistência armada". Dessa forma, concluíram que conforme "sempre pregamos diligentemente que essa lei tem de ser obedecida", não restaria outra saída a não ser reconhecer que "nesse caso é necessário lutar, mesmo se o próprio imperador nos atacar.",119

Apesar dessa capitulação formal, na expressão de Q. Skinner, Pierre Mesnard alega que o documento fora literalmente extorquido, pois aos olhos de Lutero, realmente o que valeria seria que toda rebelião, mesmo essa dita constitucional, não passaria de "um crime de lesa-majestade divina". ${ }^{120}$

Sendo concreta ou não a adesão de Lutero e seus correligionários ao direito de resistência ativa, percebe-se no reformador alemão uma postura, também de certa forma presente em Calvino, semelhante ao posicionamento de Pôncio Pilatos, uma vez que os teólogos, já fatigados com a questão da licitude ou não de uma resistência ativa, "lavam suas mãos" e entregam a pena ao jurista para discorrer sobre a questão da licitude ou não do direito de resistência a ser resolvida.

Tal postura, a nosso ver, fica clara nas palavras de Lutero, que diz ter sido a questão "resolvida por esses doutores da lei”. Em Calvino, a mesma postura é identificável, só que de forma sutil, uma vez que nas últimas linhas de sua Instituição, ao deixar a título especulativo se a França de sua época possuía ou não os mecanismos institucionais de proteção às tiranias como aferíveis na Antiguidade (a exemplo dos éforos em Esparta e tribunos em Roma), compôs um convite para o debate da questão à qual tão logo juristas como Hotman e Mornay, ou teólogos como Bèze (só que dessa vez, em larga medida despojado da condição de teólogo e paramentado com a beca do jurista) responderiam ao longo da década de 1570 .

Para Skinner, o primeiro teólogo luterano a adotar a teoria constitucional de resistência fora Andreas Osiander, já que se trata do provável autor de uma carta endereçada aos magistrados da cidade de Nuremberg em fins de 1529, intentando persuadir a cidade a participar de uma aliança defensiva junto a Felipe de Hesse contra o imperador. Em tal documento, Osiander reconhece a dificuldade imposta pelo veto paulino contido na Carta aos Romanos, mas “contorna essa aparente dificuldade com a mesma estratégia empregada pelos juristas hessenianos [...]”. Osiander afirma que a exegese correta do texto implica a

119 SKINNER, Quentin. As fundações do pensamento político. São Paulo: Cia das Letras, 2000, p. 475.

120 MESNARD, Pierre. L'essor de la Philosophie Politique au XVI Siècle.Paris: Libraire Philosophique J. Vrin, 1977, p. 228. 
compreensão de que o dever irrestrito de obediência é devido aos magistrados pios que "executam apropriadamente suas funções" e de forma alguma em Paulo tal exortação é extensível aos magistrados pecadores. Argumenta também que, para o apóstolo, são “autoridades instituídas por Deus", não apenas os "magistrados superiores" mas também os "inferiores" os "os príncipes territoriais" e um "conjunto de outras autoridades locais". Postos tais pressupostos exegéticos, tem-se como desdobramento a licitude da possibilidade de se o mais alto dos magistrados infringir seus deveres para os quais ele fora instituído, seus magistrados inferiores "que são tão magistrados quanto ele" poderem, de forma plenamente lícita, resistir-lhe, com a finalidade de que "a suprema necessidade de um governo bom e piedoso seja invariavelmente atendida"121

Porém, para o citado historiador da ideias políticas da Universidade de Cambridge, o principal desenvolvimento dessa teoria deu-se com Martin Bucer ${ }^{122}$, reformador de Estrasburgo (ponto geográfico estratégico dos limiares do mundo francófono e germânico), na obra A Explicação dos quatro evangelhos, de 1527 (porém deve-se consignar que a inserção da teoria constitucional na obra se dá somente no ano de 1530, "sob evidente pressão das circunstâncias políticas imediatas"), assim como na obra publicada postumamente em 1554, Comentários sobre o Livro dos juízes ${ }^{123}$.

Na primeira obra citada, Bucer reproduz o entendimento padrão, destacando que aos indivíduos privados cabe apenas o veto absoluto de oferecer resistência aos governantes ímpios, mas a questão deve ser colocada em padrões totalmente distintos dos antecedentes quando se tratar de autoridades públicas. Para Skinner, Bucer opera certa transferência do argumento de natureza secular para um plano mais teológico, ou ainda num "vocabulário da teologia luterana e assim afirma [Bucer] que, 'para que os assuntos humanos sejam organizados da melhor forma', Deus em nenhuma circunstância 'transferiu todo o poder para um único homem' num dado reino ou império" ${ }^{124}$.

Prosseguindo essa aclimatação do registro secular para o teológico, Bucer afirma que todas as autoridades foram instituídas para assegurar a observação das leis de Deus e os

${ }^{121}$ OSIANDER, Andreas. Brief. In: HORTLEDER, F. Der Roemischen Kaiser und Koeniglichen Maierstaten. v.2.Gotha, 1645, p. 85-5. 12 v., apud SKINNER, Quentin. As fundações do pensamento político. São Paulo: Cia das Letras, 2000, p. 480.

${ }^{122}$ Importa registrarmos a importância de Bucer e suas ideias para o pensamento de Calvino e, consequentemente, a todo Calvinismo. O reformador acolhera Calvino quando este fora expluso de Genebra em 1538, apesar dos problemas de se dizer sobre o papel de influências, Collinson aponta que com certo exagero, mas com alguma dose de verdade, os admiradores do reformador alsaciano atribuem a este último grande parte das ideias mais interessantes de Calvino, como se o mesmo “fosse apenas 'o brilhante e energético executor' de Bucer”. COLLINSON, Patrick. A Reforma. Rio de Janeiro: Objetiva, 2006, p. 113.

${ }^{123}$ SKINNER, Quentin. As fundações do pensamento político. São Paulo: Cia das Letras, 2000, p. 480.

${ }^{124}$ Ibidem, p. 480. 
magistrados inferiores, ainda que obrigados a respeitar seus superiores, sofrem uma limitação a tal dever "pela obrigação predominante" de não se facultar algo que seja contrário a vontade de Deus ${ }^{125}$. Diante de tais pressupostos, advindo uma tirania, ou seja ante magistrados superiores que se afastam de suas funções, os magistrados inferiores têm o dever de depor a magistratura superior ainda que pela força das armas. ${ }^{126}$

Quentin Skinner, ao analisar o pensamento de Bucer como evidentemente tributável aos estudos de Filipe de Hesse e seus juristas, denuncia como elemento diferenciador entre ambos o fato de que "enquanto estes [a posição dos juristas de Hesse] tratavam principalmente das obrigações legais do imperador, Bucer preocupava-se mais em salientar o dever supremo a ele atribuído de defender a verdadeira fé." 127

Esse tom mais teológico do escrito de Bucer é perfeitamente aferível na citação que segue, extraída do suporte argumentativo que Jonh Milton utilizaria no século seguinte para defender a noção de governos limitados. Assim, Bucer, em seu Comentário ao Evangelho de Mateus, descreve a conduta dos magistrados inferiores em relação a um príncipe soberano:

Se um príncipe soberano se empenha pela força das armas em defender os transgressores e subverter as coisas ensinadas na palavra de Deus, os que detêm autoridade abaixo dele devem, primeiro, dissuadi-lo; se não conseguirem, agora que ele se comporta não como príncipe mas como inimigo, e busca violar privilégios e direitos assegurados a magistrados inferiores e comunidades, cumpre aos devotos magistrados, implorando primeiro o auxílio de Deus, antes tentar todos os caminhos e meios que trair o rebanho de Cristo a tal inimigo de Deus; pois também para este fim foram ordenados: para que possam defender o povo de Deus e conservar as coisas boas e justas. Portanto, ter o poder supremo não diminui o mal cometido por esse poder, ao contrário, torna-o menos tolerável, na medida em que em geral é mais danoso. ${ }^{128}$

Melanchthon, principal líder do movimento após a morte de Lutero, em seu tratado Loci Communes Theologici, publicado na Basileia no ano 1550, em seção própria sobre os magistrados, reafirma a tese comum entre reformadores magisteriais de que os

\footnotetext{
${ }^{125}$ SKINNER, Quentin. As fundações do pensamento político. São Paulo: Cia das Letras, 2000, p. 481.

${ }^{126}$ Ibidem, p. 481.

${ }^{127}$ Ibidem, p. 481.

128 BUCER, Martin. Comentário ao Evangelho de Mateus. Apud MILTON, Jonh. A tenência de reis e magistrados. In: DZELZAINIS, Martin (org.). Escritos Políticos. São Paulo: Martins Fontes, 2005, p.56.
} 
magistrados civis exercem seu ofício com aprovação e regozijo de Deus. Porém, evocando a autoridade bíblica do Livro dos Atos dos Apóstolos, especialmente a exortação contida em Atos 5: 29, que determina a supremacia do dever de obediência devida a Deus e não aos homens, afirma de forma inequívoca que "se magistrados determinarem algo que é contrário a Deus, eles não devem ser obedecidos" ${ }^{\prime 29}$.

Ainda que no meio da seção, o autor escreve em tom cauteloso, recordando o dever do cristão de oferecer a outra face diante da agressão, nos termos de Mateus 5: $39^{130}$, como num movimento pendular de argumentação (comum a vários tratados protestantes ou tópicos dos mesmos que tenham por objeto o direito de resistência). Melanchton retoma um tom de argumentação mais arrojada, que subsidia indiretamente um direito de resistência, ao argumentar que as leis dos fariseus, e portanto humanas, foram dispensadas por Cristo, sem que com isso ele tenha extirpado as leis civis, de modo que "a regra e o sentido de todas as leis humanas estão abaixo da fé e do amor, e especialmente abaixo da necessidade. A necessidade liberta de todas as tradições se de alguma forma a alma ou a vida do corpo tenha caído em perigo graças à tradição."131

Os calvinistas, que abordam de modo original a problemática do direito de resistência com um conteúdo mais propriamente secular, sem negar a reinterpretação bíblica operada pelos luteranos que franqueiam essa oposição aos governos tiranos, dentre os quais se insere também Théodore de Bèze, com a obra Du Droit des Magistrats sur leur Sujets, de 1574, foram denominados de monarcômacos.

Tal expressão originou-se no ano de 1600, na pena do realista escocês William Barclay, com a obra De regno et regali potestate: adversus Buchananum, Brutum, Boucherium et reliquos monarchomachos, acusando os pensadores sobretudo protestantes ${ }^{132}$ que se opunham às monarquias embasadas no direito divino ${ }^{133}$.

Tais obras, surgidas principalmente na segunda metade do século XVI, e particularmente depois dos massacres da noite de São Bartolomeu em agosto de 1572, apresentavam-se muitas vezes na forma de panfletos anônimos ou assinados com pseudônimos, justificando o bom direito de resistir aos governantes que os perseguiam. ${ }^{134}$

${ }^{129}$ MELANCHTON, Philip. Loci Communes Theologici. In: PAUCK, Wilhelm. Melanchton and Bucer. Philadelphia: The Westminster Press, 1969, p. 148.

${ }^{130}$ Ibidem, p. 148.

${ }^{131}$ Ibidem, p. 150.

${ }^{132}$ Um exemplo de pensador católico que já fora chamado de monarcômaco é Etiene de la Boetie.

${ }^{133}$ RENS, Ivo. En quoi les idées politiques de Théodore de Bèze et des monarchomaques protestants innovèrentelles? In: Jacques Godefroy (1587-1652) et l' humanisme juridique à Genève. p. 175.

${ }^{134}$ Ibidem, p. 175. 
Dentro dessa nomenclatura podem ser albergadas diversas obras como:

- A short Treatise of Political Power (John Ponet, Escócia, 1536);

- First Blast of Trumpet against the Monstruous Regiment of Women (John Knox, Genebra, 1558);

- How Superior Powers ought to be obeyed (Christopher Goodman, Genebra, 1558);

- Franco-Gallia (François Hotman, Genebra, 1573);

- Le Réveille - Matin des Français et de leurs voisins (Anônimo, Basileia, 1573);

- Du Droit des Magistrats (Théodore de Bèze, Genebra, 1574);

- Stratagema di Carlo IX, rei di Francia, contro gli Ugonotti (Camillo Capilupi, Genebra, 1574);

- Discours sur les moyens de bien gouverner et maintenir en bonne paix un Royaume ou autre Principauté. Contre Nicolas Machiavel Florentin (Innocent Gentillet, Genebra, 1574);

- De Jure Regni apud Scotos (George Buchaman, Edimburgo, 1579);

- Vindiciae contra tyrannos (“Brutus", Edimburgo e Genebra, 1579);

- Politica methodice digesta (Jean Althusius 1603). ${ }^{135}$

Dentre as obras acima arroladas destacaremos duas para fazermos breves comentários, pelas relações que as mesmas possuem com a obra de Bèze ${ }^{136}$ objeto de estudo da presente dissertação, que são: Franco-Gallia, de François Hotman, de 1573 e Vindiciae contra tyrannos, de "Janus Brutus" (Hubert Languet et Philippe Du Plessis-Mornay), de 1579.

R. Kingdon assinala que $D u$ droit des Magistrats ocuparia uma posição intermediária no desenvolvimento das ideias de resistência dos huguenotes, ultrapassando Hotman, ao estender o direito de resistência aos magistrados inferiores, além dos Estados Gerais, como também se trata de uma obra mais comedida, quando comparada com Vindiciae,

\footnotetext{
${ }^{135}$ RENS, Ivo. En quoi les idées politiques de Théodore de Bèze et des monarchomaques protestants innovèrentelles? In: Jacques Godefroy (1587-1652) et l' humanisme juridique à Genève. p. 176-177. Importa o registro de que apesar da clássica listagem de obras monarcômacas ora citada, os fundamentos teóricos dos calvinistas insulares divergem dos continentais, e a obra de Althusius possui uma estrururação mais densa.

${ }^{136}$ KINGDON, R. Introduction. In: BÈZE, Théodore de. Du Droit des Magistrats. Genève: Droz, 1970, p. XLI; FRANKLIN, H. Julian. Constitutionalism and Resistance in the Sixteenth Century: Three Treatises by Hotman, Beza \& Mornay. New York: Pegasus, 1969, p. 11-46.
} 
pelo fato da mesma não reservar essencialmente o exercício do combate à tirania aos magistrados inferiores e Estados Gerais. ${ }^{137}$

Dentre os primeiros calvinistas continentais a empreenderem uma resposta ao convite deixado por Calvino em sua Instituição da Fé Cristã, a título especulativo, ou seja, se a França tinha ou não mecanismos institucionais de dar resposta aos abusos perpetrados pelos tiranos, destaca-se François Hotman, em 1573, com seu erudito estudo desde os tempos ancestrais da organização política daquilo que viria a ser o reino francês, o Franco-Gallia.

Tal obra destaca as funções mais importantes dos Estados Gerais na França, ou seja, as atribuições políticas da mais alta assembleia francesa que Bèze em larga medida defenderá em seu tratado de 1574. Dentre estas, sublinham-se: a eleição e destituição de governantes, a regência do reino, assuntos referentes a tributação, declaração de guerra, celebração de paz. Outro ponto de suma importância para os protestantes, que vislumbravam nos Estados Gerais a possibilidade de terem acolhidas suas reivindicações, consistia na afirmação de Hotman, de que a falta de convocação dos Estados Gerais em nada lhes alterava sua dignidade e prerrogativas de decisão sobre os assuntos mais relevantes do reino, podendo ser convocados a qualquer tempo sem prescrição dos poderes de tal assembleia pelo decurso do tempo.

No início do capítulo XI de Franco-Gallia, cujo tópico é bastante esclarecedor: Da sagrada e involável autoridade da assembleia geral dos Estados, e daquelas matérias lá tratadas, Hotman assim descreve as principais funções dos Estados, já sabiamente instituídas nos primórdios do reino para o bem de todos, e que devem ser exercidas em seu tempo, pois tal autoridade ainda continuaria em pleno vigor:

Ora é aqui o lugar próprio no qual é necessário que consideremos que matérias são decididas nesta assembleia solene: e admiremos o grande senso e a prudência que nossos Maiores mostraram ao estabelecer e ordenar a forma de sua organização. Eis, pois, sumariamente, quase todas as metérias que eram deliberadas ali: primeiramente, sobre a eleição ou a deposição de um rei; consequentemente, sobre a paz e a guerra, as leis públicas, os estados soberanos e ofícios. Governos e administrações da coisa pública; a atribuição de alguma parte do domínio aos herdeiros masculinos do rei

\footnotetext{
${ }^{137}$ KINGDON, R. Introduction. In: BÈZE, Théodore de. Du Droit des Magistrats. Genève: Droz, 1970, p. XLI. Importa registrar que Bèze não exclui a possibilidade, em caráter excepcional o exercício de resistência por parte de um particular contra um tirano manifesto, desde que para isso haja indubitável e extraordinária vocação, porém por cautela, nosso autor se furta a desenvolver tal temática com a mesma ênfase de "Brutus".
} 
defunto. Ou o estabelecimento de bens às filhas mulheres (o que chamam apanágio, palavra alemã, que significa parte exclusiva, ou seja, que exclui os filhos mais novos e as filhas do direito que poderiam ter na ocasião da sucessão); finalmente, sobre todas as metérias que até o presente chamam-se comumente de negócios de Estado, desde que não seja permitido decidir sobre alguma questão concernente ao estado da coisa pública senão na assembleia dos Estados. ${ }^{138}$

Quanto à recusa de um papel no exercício do direito de resistência por parte dos magistrados inferiores, reservado apenas às "assembleias que representam o conjunto da população", ou seja, os Estados Gerais na obra de Hotman, R. Kingdon chega a vislumbrar que haveria uma repercussão de suas convicções religosas com um elemento de natureza pessoal e de certo revanchismo, pois a sua amargura quanto aos corpos judiciários dos parlamentos regionais ${ }^{139}$ decorreria, dentre outros motivos, do fato de os mesmos tentarem barrar o avanço do protestantismo, seja ao aplicarem com rigor as leis que puniam heresias, ou ao sistematicamente se recusarem a "registrar os éditos de tolerância ou atos que os confirmassem quando a coroa os emitia.",140

Tais atitudes, no mínimo refratárias, para não se dizer agressivas, quanto aos parlamentos apresenta-se sobretudo no capítulo XX, que versa sobre Os Parlamentos e sedes judiciais. Hotman diz que tais entes políticos eram desconhecidos dos ancestrais de sua nação e, portanto, careciam da mesma legitimidade que as assembleias dos Estados Gerais, e inclusive acusa-os de usurpar as sagradas e invioláveis prerrogativas dos mesmos, como também a dignidade dos reis (na medida em que várias decisões reais apenas se executavam com a anuência dessas cortes), além de se proliferarem em demasia pelo reino em tom virulento $^{141}$, transformando a França em um Reino de Demandas Judiciais ${ }^{142}$.

\footnotetext{
${ }^{138}$ HOTMAN, F. La Gaule Française (Franco-Gallia). Paris: Fayard, 1991, p. 105.

139 Ainda que em Bèze não encontremos a expressão para designar o conjunto de magistrados inferiores como parlamentos ou sedes judiciais, comentadores como Franklin e Kingdon afirmam que os mesmos, que aparecem nas últimas páginas de Francogallia de Hotmam, dizem respeito aos magistrados inferiores objeto de análise de Bèze em seu tratado, que por sua vez, apresentam-se como perfeitamente compatíveis com os Estados Gerais aptos a salvaguadar os súditos de uma tirania enquanto os Estados não dão uma solução definitiva. (KINGDON, R. Introduction. In: BÈZE, Théodore de. Du Droit des Magistrats. Genève: Droz, 1970, p. XXXVIII-XLI; FRANKLIN, H. Julian. Constitutionalism and Resistance in the Sixteenth Century: Three Treatises by Hotman, Beza \& Mornay. New York: Pegasus, 1969, p. 11-46).

${ }^{140}$ KINGDON, R. Op. cit., p. XXXIX.

${ }^{141}$ Hotman cita a existência de sete Cortes soberanas e Parlamentos erigidos na França nas cidades de Paris, Toulouse, Ruão, Grenoble, Bordéus, Aix e Dijon, que seriam fixas, assim como aponta a existência de uma oitava itinerante, sem sede fixa, denominada Grande Conselho, além de denunciar o fato de tal crescimento ter origem na inveja e vontade das cidades abrigarem essas sedes de jurisdição, pois a instalação das mesmas
} 
Ainda em tom acusatório e de desprestígio aos órgãos que agrupam os magistrados inferiores, Hotman, em seu estudo da origem e evolução das instituições francesas, aponta a consquista dos poderes indevidos por essas assembleias de dignidade inferior aos Estados Gerais, que se deu em larga medida por uma estratégia de se obter o fenecimento da Assembleia dos Estados, operacionalizada pelos reis descendentes de Hugo Capeto, usurpando inclusive desta última o "nome venerável de Parlamento"143, de modo a conferir a essas assembleias regionais progressivamente poderes e prerrogativas, da seguinte maneira $^{144}$ :

Mas os Reis da casa dos Capetos, para fazê-la fenecer pouco a pouco, e para fazê-la perder tudo, substituíram um certo número de conselheiros nesta assembléia geral, e lhe tiraram o nome venerável de parlamento, para dá- lo a este conselho que tinham posto em seu lugar, de resto, o rodearam de uma maravilhosa autoridade e grandes prerrogativas. Pois primeiramente ordenaram que não haveria lei nem ordenança real que fosse válida, se primeiramente ela não tivesse sido aprovada, verificada e autorizada por esses Conselheiros, em segundo lugar que não haveria magistrado em toda França nem civil ou militar, que fosse instalado e tomasse posse de seu estado por esta corte e que não prestasse juramento entre suas mãos, e em seguida que não fosse lícito recorrer de seus julgamentos e sentenças mas que suas decisões fossem firmes e irrevogáveis. Finalmente, este suposto parlamento tirou e usurpou todo poder e autoridade dos quais tinha gozado por tantos anos o Conselho dos Estados, assim como foi mostrado, este suposto Parlamento, os tirou inteiramente e os usurpou para si e para manter assim deu ordem que os reis fossem de sua compainha, pelo menos aqueles que eles estimaram não ser contrários aos seus desígnios. ${ }^{145}$

fatalmente atraía privilégios para a região. HOTMAN, F. La Gaule Française (Franco-Gallia). Paris: Fayard, 1991, p. 170.

${ }^{142}$ HOTMAN, F. Op. cit., p. 169-171.

${ }^{143}$ Para Hotman, a origem da expressão Parlamento, que em seu tempo estava sendo utilizada para nomear as principais sedes de Judicatura, no francês arcaico, era reservada somente para circunstâncias especiais como em colóquios ou conferências para tratar e consultar o conjunto de negócios públicos. Especificamente os antigos cronistas do reino denominavam de parlamento a circunstância de quando "dois Príncipes ou dois Chefes de guerra, [...] queria tratar e capitular algum acordo de paz em conjunto." e por essa mesma importância, autoridade e poder que a expressão guardava em francês arcaico, também se passou a denominar parlamento o Conselho Geral dos Estados. HOTMAN, F. La Gaule Française (Franco-Gallia). Paris: Fayard, 1991, p. 171.

${ }^{144}$ Ressalvamos que o texto sugere especificamente nesta oportunidade a descrição da usurpação feita pelo parlamento judicial de Paris, porém tal rol de usurpações das faculdades da Assembleia dos Estados Gerais afere-se também como praticado em maior ou menor grau por parlamentos judiciais de outras regiões da França.

${ }^{145}$ HOTMAN, F. La Gaule Française (Franco-Gallia). Paris: Fayard, 1991, p. 171-172. 
Com referência à obra Vindiciae contra Tyrannos, de autoria de Stephanus Junius Brutus, vinda a lume no ano de 1579 , deve-se destacar a reafirmação da capacidade dos magistrados inferiores de atuarem ativamente no controle dos govenantes tirânicos, além dos Estados Gerais, (como T. de Bèze já havia desenvolvido anteriormente), como também o desenvolvimento de um tópico mais próprio do domínio teológico do que propriamente político que seria o das vocações extraordinárias que pessoas privadas podem receber, mas que nosso autor (Bèze) ainda que reconheça sua possibilidade, recusa-se a desenvolver em sua amplitude ${ }^{146}$, talvez até pelos perigos de sublevação popular que a dissiminação de tal entendimento pudesse ocasionar.

O tratado é constituído de quatro questões básicas, a saber:

I - Se os súditos estão constrangidos e devem obedecer aos Príncipes, se eles ordenam alguma coisa contra a Lei de Deus.

II - Se é lícito resistir a um Príncipe que quer eliminar a Lei de Deus, ou que arruíne a Igreja. Como também, a quem, como, e até que ponto é lícito.

III - Se é lícito resistir a um Príncipe que oprima ou arruíne um estado público, e até que ponto esta resistência é possível. Como também a quem, como, e por qual direito, isso é permitido.

IV - Se os príncipes vizinhos podem ou estão constrangidos de pleno direito a dar socorro aos fieis de outros Príncipes, afligidos por causa da verdadeira Religião, ou oprimidos pela tirania manifesta ${ }^{147}$

No bojo de tais questões, afere-se uma boa síntese dos demais tratados políticos huguenotes anteriores que, segundo George H. Sabine, havia se convertido "em um dos marcos da literatura revolucionária, voltando-se a publicar repetidas vezes, na Inglaterra e nos demais países, cada vez que a oposição entre monarca e povo chegava a uma nova crise."148 Talvez, devido ao fato de ser uma síntese das demais obras huguenotes antecedentes e de ter sido traduzida para diversos idiomas (ou pelo menos trechos do tratado), popularizando-se nas áreas de expansão da fé calvinista ou apenas reformada, como no caso alemão, de

\footnotetext{
${ }^{146}$ Afirmamos que Théodore de Bèze aceita a possibilidade de haver o fenômeno da vocação extraordinária permitindo, portanto, em boa consciência um particular empunhar o gládio contra o tirano, mas o autor recusa-se a desenvolver no tratado maiores explicações sobre o fenômeno com base no seguinte trecho do capítulo VI da obra Droit des Magistrats: "Eu digo que sem extraordinária vocação de Deus, a qual eu não questiono, não é lícito a nenhum particular opor-se contra a força do Tirano desde sua autoridade privada." Optando nosso autor a solucionar, conforme veremos, o problema da tirania por um viés de instituições. BÈZE, Théodore de. Du Droit des Magistrats. Genève: Droz, 1970, p.. 16.

${ }^{147}$ BRUTUS, Etienne Junius. Vindiciae contra Tyrannos. Genève: Droz, 1979, p. 2.

${ }^{148}$ SABINE, George H. Historia de la teoria política. México: Fondo de Cultura Económica, 2006, p. 298.
} 
predominância luterana ${ }^{149}$, faça com que haja certo entusiasmo na recepção da crítica desta obra por comentadores como Sabine, Skinner e Mesnard ${ }^{150}$.

Porém, apesar da generosa recepção da referida obra, importa o registro de não se vislumbrar nela um elemento de originalidade propriamente político, como ocorrerá no tratado de Bèze de 1574, que insere a função dos magistrados inferiores no papel da defesa do povo contra as tiranias, além de reafirmar a dignidade e prerrogativas dos Estados Gerais. O elemento de originalidade mais destacável no tratado de Junius Brutus, segundo a crítica

149 José Olegário Ribeiro de Castro, em sua tese de livre-docência apresentada à Faculdade de Ciências Econômicas da Universidade Federal de Minas Gerais (na certa um dos trabalhos precursores no estudo dos monarcômacos no Brasil), apresentada no ano de 1960, aponta uma íntima relação entre a data das publicações da obra Vindiciae contra Tyrannos e eventos revolucionários na política de várias nações que tiveram uma edição da obra. Por exemplo, cita a primeira edição da obra em 1579, ocorrida em Edimburgo, que se associa ao ambiente vivido por aquela nação, cheia do "proselitismo de John Knox, aguçado de frescor pelos ensinamentos a um tempo teológicos e políticos recebidos em Genebra, havia se aliado aos interesses dos nobres, dos chamados chefes de clãs, dos Lairds da Congregação, zelosos de suas liberdades de montanheses orgulhosos para conduzir a vitória final de 1570." Além disso, Olegário, em seu esforço de reconstrução da evolução da publicação das Vindiciae, narra o fato de que essa mesma primeira edição de 1579 se deu sob o patrocínio de Loiseleur, senhor de Villiers, capelão do príncipe de Orange, Guilherme, o Taciturno, ligando-se dessa forma à história dos Países Baixos, ocasião em que eclodem edições nos anos de 1611 e 1660, em Amsterdam, e 1643 e 1648, em Leyde, período que compreende, segundo o pesquisador brasileiro ora referido, a Guerra dos Oitenta Anos (1568-1648), onde a nobreza batava já aderia progressivamente à fé reformada e tinha bastante interesse em aceitar as teses de resistência da obra, pois ocorria nas circunstâncias do conflito "a reação da nobreza contra a centralização administrativa, contra o absolutismo espanhol (Compromisso dos Nobres - 1564), sua adesão sempre crescente à causa reformista jamais se distancia dos interesses das igrejas e da autoridade (Buldenstorm de 1566), ódio mortal à tirania presente do duque de Alba, emissário fiel do tirano ausente enfurnado em suas salas frias e distantes do Escorial, tirania a um tempo política, religiosa e fiscal - tudo isso conduzindo à luta espasmódica, onde as batalhas e tréguas, alianças e traições, pazes e éditos e, especialmente, a conjunção análoga de causas de natureza vária, lembram bem a situação idêntica da França vizinha.”. Além do mais o estudioso mineiro, em nota expõe o fato de que a primeira versão em língua francesa teve lugar e ano de publicação na Amsterdam de 1581, onde ocorrera a assembleia dos Estados Gerais dos Países Baixos em que fora deposto Filipe II. Ademais, ao reproduzir trecho da Ata de Abjuração do soberano espanhol pelas autoridades batavas, que talvez seja a primeira operacionalização em termos práticos da literatura calvinista continental, J. Olegário expõe a inconteste influência da literatura monarcômaca sintetizada na obra de Brutus, na referida declaração histórica: "Toda a humanidade sabe que um príncipe é designado por Deus para cuidar de seus súditos, do mesmo modo que um pastor o é para guardar suas ovelhas. Portanto, quando o Príncipe não cumpre seu dever de protetor, quando oprime seus súditos, quando destroi suas antigas liberdades e os trata como escravos, há de ser considerado não como um Príncipe, mas como um tirano. Em tal caso, os Estados do país podem depô-lo e eleger outro em seu lugar". No caso da Alemanha, apontam-se edições em 1595 (Hanover), 1600 (Ursel), 1608 (Frankfurt) e 1622 (Estrasburgo), sendo que a boa recepção da obra se justificaria em tais cidades por apresentarem um histórico de resistância a investidas de centralização política e uniformidade religiosa por parte do Imperador. Por último destaca uma edição suíça na Basileia, cidade que testemunhara a publicação da Instituição de Calvino. Para José Olegário, a função das Vindiciae, e no bojo dela as noções fundamentais da literatura monarcômaca continental prestaram-se sobretudo a estimular "reação cantonal à política da ContraReforma [centralizadora] que, sob a direção lúcida do cardeal Carlos Borromeu, incentivava as aspirações monárquicas de Ludwig-Pfyffer - o 'rei dos suíços' - [...]”. (CASTRO, J. O contratualismo ideológico do "Vindiciae contra tyrannos". Belo Horizonte, UFMG: 1960. Tese (Livre-docência em História da Política da Faculdade de Ciências Econômicas ), Universidade Federal de Minas Gerais, 1960, p. 13-17).

${ }^{150}$ SABINE, George H. Historia de la teoria política. México: Fondo de Cultura Económica, 2006, p. 297; SKINNER, Quentin. As fundações do pensamento político. São Paulo: Cia das Letras, 2000, p. 481 e 576; MESNARD, Pierre. L'essor de la Philosophie Politique au XVI Siècle. Paris: Libraire Philosophique J. Vrin, 1977, p. 340. 
especializada $^{151}$ seria a possibilidade do papel do exercício das vocações extraordinárias, o que nos parece uma discussão mais apropriada para a esfera teológica do que propriamente política.

Esse elemento de originalidade, enfatizamos, já vislumbrado por Bèze mas que não é por ele desenvolvido, encontra guarida no tratado de Junius Brutus na Segunda Questão, oportunidade em que o autor, apesar de reconhecer aos particulares a impossibilidade de ordinariamente resistir, caso "os principais do Reino e os magistrados" aclamem o tirano e não lhe ofereçam resistência, devem se contentar com o conselho de Jesus Cristo, expresso em Mateus, Capítulo 10, no qual "o senhor dos Reis" exorta que no caso de perseguição por se professar e pregar a verdadeira fé, deve o discípulo abandonar a área territorial de mando do tirano, ou na expressão de Brutus: "se retirar para outra parte"152.

Porém, Brutus, apesar de reproduzir o argumento tradicional da reforma magisterial quanto a não conferir às pessoas privadas a faculdade de licitamente resistir, insere e desenvolve a questão da vocação extraordinaria, pois assim expõe o problema:

E será portanto, permitido a algum particular de resistir com armas ?Que diremos de Moisés, que levou Israel, malgrado o Rei Faraó ? E de Aod, que depois de dezoito anos, em que o reino parecia pertencer por direito de prescrição àquele que o apreendeu, matou Eglon Rei de Moab, e livrou Israel do jugo dos moabitas ? E de Jeú, que condenou a morte seu Senhor o Rei Jorão, exterminou a linhagem de Acabe assim como todos os seguidores de Baal ? Não eram eles particulares ? Eu respondo que, se os consideramos eles mesmos, poderia-se chamá-los de particulares, porém eles não tinham uma vocação ordinária, mas então sabemos que eles tinham sido extraordinariamente chamados, e que Deus ele mesmo (por assim dizer) colocou a espada em suas mãos, de tal forma que é preciso, considerá-los não apenas particulares ou pessoas privadas, mas também os compreendermos como muito mais que qualquer magistrado ordinário em qualquer grau que eles possam estar. ${ }^{153}$

\footnotetext{
${ }^{151}$ FRANKLIN, H. Julian. Constitutionalism and Resistance in the Sixteenth Century: Three Treatises by Hotman, Beza \& Mornay. New York: Pegasus, 1969, p. 39-44; KINGDON, R. Introduction. In: BÈZE, Théodore de. Du Droit des Magistrats. Genève: Droz, 1970, p. XLI.

${ }^{152}$ BRUTUS, Etienne Junius. Vindiciae contra Tyrannos. Genève: Droz, 1979, p. 85.

${ }^{153}$ Ibidem, p. 85-86.
} 
Apesar do avanço de uma radicalidade na obra Vindiciae ao direito de resistência, importa o registro de que as três obras calvinistas acima mencionadas possuem como marca indelével um direito de resistência institucionalizado, previamente ordenado por pactos no campo temporal e perfeitamente compatibilizados com os ditames divinos, e refratários, em regra, a todo e qualquer movimento que tenha uma atuação extraviada dos ditames acima mencionados, sob pena de ser considerado sedicioso e aprioristicamente censurável pelas leis de Deus e dos homens.

Em suma, depreende-se dos movimentos luteranos e calvinistas, constrangidos a dialogar com os ensinamentos de Lutero e Calvino, precurssores da fé que professavam, que $a$ priori eram refratários a todo e qualquer movimento de oposição aos governos instituídos, mesmo quando tidos por tiranos, e com o movimento dos reformadores radicais, com toda uma desenvoltura de justificativa de destituição não-burocratizada das autoridades refretárias às novas práticas religiosas e civis de seus seguidores, que tais discípulos de Lutero e Calvino compõem um discurso legitimador da resistência sem alterar suas condições de reformadores magisteriais, na exata medida que alijam a participação popular, sobretudo ao aderirem e desenvolverem o "argumento constitucional de resistência dos magistrados" de uma comunidade política, chegando mesmo Bèze, conforme veremos, a alçá-lo de forma inequívoca a um status de universalidade. 


\section{CAPÍTUlO II - AS FONTES MEDIEVAIS, CATÓlicAS E SECULARES PARA O CONSTITUCIONALISMO DE THÉODORE DE BÈzE E SUAS PRIMEIRAS INCURSÕES NO DEBATE POLÍTICO DO DIREITO DE RESISTÊNCIA}

No presente capítulo, objetiva-se tratar de influências na obra de Théodore de Bèze que extrapolam os limites da consolidação, na época, de pensamento político e teológico reformado, privilegiando autores e temáticas inclusive genuinamente católicos, e mesmo seculares que deixam traços indeléveis na obra objeto de análise. Apresentaremos também as primeiras incursões no debate do direito de resistência em obras que antecederam a publicação de Du Droit des Magistrats, em 1574.

No que tange à argumentação católica, são oportunas as palavras de Skinner, ao apontar que, ainda que se fale em uma revolução calvinista perpetrada pelos autores da década de 1570, importa o registro de que já os autores calvinistas na década de 1550 (Knox, Ponet e Goodman) haviam se valido dos trabalhos dos autores luteranos, que por sua vez derivavam do direito civil e canônico. Os de duas décadas depois como Bèze teriam acrescentado argumentos oriundos da escolástica, de modo que "podemos afirmar, sem muito exagero, que na verdade os principais alicerces da teoria calvinista da revolução foram integralmente construídos por seus adversários católicos." ${ }^{154}$

Quanto aos argumentos de natureza secular, ou seja, aqueles de natureza nãoconfessional, originados da Reforma ou do Catolicismo medieval, destacaremos no presente capítulo a emergência de duas formas peculiares de direitos: o urbano e o feudal, que, forjados durante as transformações sociais da Europa da Baixa Idade Média, fortalecem a argumentação de Bèze, na medida em que o primeiro legitima a autoridade dos agentes políticos regionais alocados na cidades e vilas, ao passo que o direito feudal legitima a quitação das obrigações de um vassalo perante o seu senhor, que analogicamente nosso autor aplicará para as relações do súdito com o soberano.

Por fim, pretende-se fazer referências às primeiras incursões de Bèze quanto ao direito de resistência nas obras Da punição dos hereges pelo magistrado civil, de 1554, e Confession de la foi Chrestienne, em sua segunda versão de 1560, apontando-se a evolução de seu pensamento, quando comparadas com Du Droit des Magistrats de 1574.

${ }^{154}$ SKINNER, Quentin. As fundações do pensamento político. São Paulo: Cia das Letras, 2000, p. 591. 


\subsection{A construção teórica escolástica de resistência à tirania}

Ainda que a Reforma Protestante possa ser encarada por alguns autores como uma ruptura da tensão entre dois catolicismos, conforme visto anteriormente, e Calvino tenha escrito palavras no mínimo nada elogiosas à escolástica ${ }^{155}$, o fato é que a obra de Théodore de Bèze, por seu turno, mostra-se como devedora dos escritos de São Tomás.

No plano formal, Bèze confere ao tratado de 1574 a forma de disputatio, muito próxima do debate medieval, tal como em São Tomás, consistindo numa tentativa de resposta "a uma questão dialética e dilemática”, iniciando-se por argumentos em regra contrários a tese do autor, para posteriormente se apresentar os argumentos que lhes são favoráveis e, por fim, dar "a solução que se havia escolhido e se termina por uma resposta às objeções que leva ao silêncio definitivo dos argumentos adversos." 156

Na Súmula Teológica, no artigo IV da Questão XCVI, que versa sobre "O poder da Lei Humana", Tomás de Aquino já expõe a desobrigação de se obedecer leis injustas que contrariam os ditames de Deus, de forma extremamente próxima a que se encontrará no primeiro capítulo da obra de Bèze, objeto central de nossa dissertação, inclusive com a mesma referência bíblica, pois assim diz o Doctor Angelicus: "podem as leis ser injustas, por contrariar o bem divino, quais leis dos tiranos que levam à idolatria ou a qualquer outra prática contrária à lei divina. De nenhum modo é lícito observar tais leis, pois como se diz nos Atos $(5,29)$ 'É mister obedecer antes a Deus que aos homens",157

Quanto à problemática do dever do príncipe de estar ou não vinculado à obediência das leis, Tomás aponta que ele "está isento da lei quanto à força coativa da lei, pois ninguém, em sentido próprio, é coagido por si mesmo; ora, a lei só tem força coativa em

155 Calvino se digna a expor suas objeções à doutrina dos escolásticos, principalmente sobre o problema teológico da penitência, assim como rechaçar a forma de expor sua doutrina em rodeios nada esclarecedores sobre a questão, de uma maneira sistemática em capítulo próprio no corpo da Instituição (Cap. V, Livro III, Quão longe está da pureza do Evangelho tudo o que os escolásticos tagarelam sobre a penitência em suas escolas. Sobre a confissão e a satisfação). CALVINO, João. Tomo 2. São Paulo: Editora Unesp, 2007, p. 95139.

${ }^{156}$ PÉRIGOT, Béatrice. Du Droit des Magistrats de Théodore de Bèze et Franco-Gallia de François Hotman: Deux Méthodes au service da la Philosophie Politique. In: BACKUS, Irena (org.) Théodore de Bèze (15191605): Actes du Colloque de Genève (septembre 2005), Travaux d'Humanisme et Renaissance, CDXXIV. Genève: Droz, 2007, p. 557. O historiador Patrick Collinson aponta como fator de distanciamento entre as obras de Calvino e Bèze a forma de expor as ideias escolasticamente deste último: "[...] Beza e os teólogos de Heidelberg [peculiar cidade alemã que adere ao calvinismo, e não às teses de Lutero] têm sido reconhecidos para transformar a divindade [o pensamento teológico] calvinista em uma espécie de novo escolasticismo, um sistema de proposições a serem afirmadas, atacadas e defendidas com as armas da dialética e muito dependente de textos de prova, alguns dos quais foram usados para provar o Presbiterianismo. Isso divergia do método teológico do humanismo de Calvino.” COLLINSON, Patrick. A Reforma. Rio de Janeiro: Objetiva, 2006, p. 122

${ }^{157}$ AQUINO, S. Tomás de. Súmula Teológica. In: DZELZAINIS, Martin (org.). Escritos Políticos. Petrópolis: Vozes, 1997, p. 103. 
razão do poder do príncipe. Assim, pois, o príncipe diz-se isento da lei porque ninguém pode pronunciar contra ele um juízo condenatório, se vier a agir contra a lei”; além do mais, o "douto santo" que adorna os altares católicos, diz estar o príncipe acima da lei na medida em que possui a faculdade de "se for isto vantajoso, poder mudá-la e dela dispensar, segundo o tempo e o lugar" ${ }^{\prime 158}$.

Porém, T. de Aquino não deixa de dar uma recomendação, de natureza moral, sem poder vinculante, já que para o teólogo expoente da Escolástica seria proveitoso ao príncipe obedecer sem constragimentos externos a si mesmo e humanos, pois: "segue-se, não estar o príncipe isento da lei quanto ao vigor diretivo desta perante o juízo de Deus, mas deve cumprir a lei voluntariamente e não por coação."159

Na obra inconclusa do padre dominicano, Do reino ou do governo dos príncipes ao Rei de Chipre, Tomás de Aquino alerta quanto aos perigos de uma insurreição, no capítulo VII, de tal modo que se não for excessiva a tirania, aconselha-se a resignação e a tolerância, uma vez que piores males poderiam advir de uma aniquilação fulminante do tirano, tendo em vista que "pode, certamente, acontecer não cheguem a prevalecer contra o tirano os que se lhe opõem e assim ele, provocado, se enfureça mais. Se entretanto, puder alguém vencer o tirano, deste fato mesmo advirão, muitas vezes, gravíssimas dissensões no povo, dado que, durante a insurreição contra o tirano, ou derrubado ele, a multidão divide-se em facções, quanto à organização política. Dá-se, por vezes, o caso de, quando a multidão expele o tirano, ajudada por alguém, este, apanhando o poder, assumir a tirania e, temendo sofrer de outrem o que fez contra aquele, oprimir os súditos em mais grave servidão."

Quanto aos exemplos de tiranicídio narrados no Antigo Testamento, T. de Aquino diz serem os mesmos incompatíveis com a doutrina apostólica, sobretudo ao evocar a autoridade dos ditames de S. Pedro que exortaria a submissão ( $\operatorname{Pd} 1$ : 2,18); e quanto ao exemplo de Aod $^{161}$ ter matado Eglon, rei de Moab, tal narrativa deveria ser desqualificada como um exemplo que autoriza o tiranicídio nos seguintes termos: "Quanto a Aod deve-se

${ }^{158}$ AQUINO, S. Tomás de. Súmula Teológica. In: DZELZAINIS, Martin (org.). Escritos Políticos. Petrópolis: Vozes, 1997, 106.

${ }^{159}$ Ibidem, p. 106.

${ }^{160}$ AQUINO, S. Tomás de. Do Reino ou do governo dos príncipes ao Rei de Chipre. In: DZELZAINIS, Martin (org.). Op. cit., p. 139.

${ }^{161}$ Paradigma tiranicida bíblico que seria séculos depois louvado pelo monarcômaco Junius Brutus na obra Vindiciae contra tyrannos, sob o argumento de estar tal personagem bíblico autorizado a assim proceder por uma "vocação extraordiária". 
julgá-lo ter morto antes um inimigo [estrangeiro] que um chefe do povo" ${ }^{\text {,62 }}$, ou seja tal rei, em verdade, nunca fora senhor legítimo de Aod.

Por fim, arremata sua recusa da popularização do combate às tiranias, sob o argumento de que a condescendência com o assassinato de governantes por particulares, mesmo que tiranos, poderia inspirar os maus dispersos na multidão a se valerem do mesmo expediente, de modo que, além desses perversos se safarem da realidade merecida de que "aos maus costuma ser pesado o senhorio dos reis [mesmo que justos] não menos que o dos tiranos"; além do mais assevera "assim, pois, da iniciativa de tais pessoas mais correria a multidão o perigo de perder o rei bom, do que ser remediada com o afastamento do tirano."163

Como solução para o problema de se evitar a popularização do combate aos tiranos, S. Tomás sugere a transferência da atuação anti-tirânica para as autoridades constituídas: "quer, assim, parecer que não se deve proceder contra a perversidade do tirano por iniciativa privada, mas sim pela autoridade pública" ${ }^{164}$, e tal como Agostinho, manejando a pena como historiador do império romano, em sua Cidade de Deus, S. Tomás cita os exemplos de Tarquínio, o Soberbo, morto pelo senado, e o de Domiciano, cujo conjunto de ações tirânicas fora "anulado, justa e proveitosamente, por decreto do senado, tudo o que perversamente fizera a Roma." ${ }^{165}$. Como último exemplo é citada a atuação do senado romano que por decreto restitui “a Éfeso São João Evangelista, dileto discípulo de Deus, que pelo mesmo Domiciano fora relegado ao exílio na ilha de Patmos."166

De uma forma análoga, Tomás de Aquino, expõe uma teoria contratual genérica, que na certa muito se aproxima daquilo que seria lido séculos depois nos tratados protestantes do século XVI, de forma mais expandida e detalhada, já que o autor fundamenta as destituições dos tiranos ou de seus atos pelas autoridades públicas que representam o conjunto do povo, nos seguintes termos: "competindo ao direito de qualquer multidão [devidamente representada por algum ente político institucionalizado] prover-se de rei, não injustamente pode ela destituir o rei instituído ou refrear-lhe o poder, se abusar tiranicamente do poder real. Nem se há de julgar que tal multidão age com infidelidade, destituindo o tirano, sem embargo de se lhe ter submetido perpetuamente, porque mereceu [que] não cumpram os súditos para

\footnotetext{
${ }^{162}$ AQUINO, S. Tomás de. Do Reino ou do governo dos príncipes ao Rei de Chipre. In: DZELZAINIS, Martin (org.). Escritos Políticos. Petrópolis: Vozes, 1997, p. 140.

163 Ibidem, p. 140.

${ }^{164}$ Ibidem, p. 140.

${ }^{165}$ Ibidem, p. 140-141.

${ }^{166}$ Ibidem, p. 141.
} 
com ele o pactuado, não se portando ele fielmente, no governo do povo, como exige o dever de rei." 167

Por fim, ainda cabe mencionarmos a importância do doutor da Igreja ora referido, para o surgimento de instituições representativas aptas a legitimamente controlarem os governantes, segundo Paul E. Sigmund, que expõe o fato de São Tomás ter sido um dos primeiros a chancelar "a participação popular [pela via das instituições] no governo, apesar do fato de estar escrevendo antes da emergência das instituições representativas nacionais."

\subsection{O recurso ao constrangedor argumento católico dos conciliaristas}

Em Bèze lê-se, em seu capítulo VI do tratado de 1574 uma referência explícita à tradição dos conciliaristas originada no seio da Igreja Católica, durante o período medieval e que avançara até a modernidade: “[...] entre a parte mais sã daqueles que se chamam católicos Romanos, [é afirmado] que o Concílio Universal está acima do papa, com o poder de depô-lo, em caso de heresia. Segue-se que os Reis possuem mais autoridade que os papas, e que a heresia é crime menor que a Tirania, ou que os povos possuem bem tanto o poder sobre seus Reis tornados Tiranos como um Concílio sobre um papa herético."169

Para Q. Skinner, tal referência também aferível em outros escritos monarcômacos tratar-se-ia de um constrangedor argumento utilizado pelos protestantes calvinistas do continente ou insulares ${ }^{170}$. Constrangimento, que poderia ser considerado não somente como o de se recorrer a uma fonte católica de argumentação a sua própria causa, como também pode-se falar em um constrangimento da parte do auditório católico que se deparasse com tais argumentos.

A origem dessa construção teórica pode ser identificada no século XII, como uma reação às reformas gregorianas que centralizavam o poder da Igreja nas mãos do papa, e a

\footnotetext{
${ }^{167}$ AQUINO, S. Tomás de. Do Reino ou do governo dos príncipes ao Rei de Chipre. In: DZELZAINIS, Martin (org.). Escritos Políticos. Petrópolis: Vozes, 1997, p. 140.

168 SIGMUND, Paul E. Law and politics. In: KRETZMANN, Norman; STUMP, Eleonore. The Cambridge Companion to Aquinas. Cambridge: Cambridge University Press, 1993, p. 220.

${ }^{169}$ BEZZE, Théodore de. Du Droit des Magistrats. Genève: Droz, 1970, p. 52-53.

${ }^{170}$ SKINNER, Quentin. As fundações do pensamento político. São Paulo: Cia das Letras, 2000, p. 504.
} 
primeira teorização consistente do pensamento conciliar já existiria no início da década de 1190, no comentário aos Decretais, elaborado por Huguccio, bispo de Pisa ${ }^{171}$.

Tal tradição, que recebe contribuições durante a Idade Média de autores como Guilherme de Occam, Marsílio de Pádua, D’ Ailly, Jean Gerson, dentre outros, que afirmam de forma inequívoca a possibilidade de um concílio da Igreja destituir um papa herege, recebida por dois autores cronologicamente próximos de Bèze, Almain e Mair, que inclusive tentam responder às teses opostas ao conciliarismo do Cardeal Cajetan, já no século XVI. ${ }^{172}$

Jacques Almain, em sua obra Sobre a Autoridade da Igreja, dentre vários argumentos, afirma inequivocamente haver um maior poder em determinadas circunstâncias na Igreja do que no pontífice, pois, do contrário, absurdos derivariam dessa situação, como por exemplo: "Supondo que o poder sobre toda a Igreja tenha sido conferido ao papa de tal forma que ele o exerça para a destruição da Igreja e não para a sua edificação, e embora ele fosse pernicioso para toda Igreja em relação ao objetivo de seu fim, ele não poderia ser punido pela integralidade da Igreja." ${ }^{173}$ Decorrendo de tal insensatez, ocorreria algo inclusive "[...] em detrimento do próprio papa; uma vez que ele seria o mais miserável dentre os homens se ele não pudesse ser resgatado do mal." 174

No caso de haver a recusa do papa em convocar uma assembleia de natureza conciliar, Almain, recorrendo à autoridade de D' Ailly e, baseado no livro bíblico dos Atos dos Apóstolos, resolve o problema da seguinte forma: "não é improvável dizer que essa autoridade [a de se convocar um concílio] pertence àquele colégio [o dos apóstolos] pela lei divina, se o papa se recusar a assembleiar um concílio quando um caso de necessidade surgir. Pois, os doze apóstolos, e não só Pedro, reuniu a multidão dos discípulos (Atos 6:2). Disso parece depreender que não apenas os que receberam a ordenação episcopal devem ser chamados para um concílio ter uma voz deliberativa, mas também aqueles que receberam a ordenação de padre paroquial, que são sucessores dos discípulos." ${ }^{175}$, o que mostra uma expansão até as bases da Igreja, numa dinâmica democratizadora da faculdade de se convocar um concílio para se repreender um papa herético ou tirano, retirando o monopólio da aristocracia cardinalícia ou episcopal e, conferindo, dessa forma, a toda Igreja uma maior sanidade de seu funcionamento.

\footnotetext{
${ }^{171}$ SKINNER, Quentin. As fundações do pensamento político. São Paulo: Cia das Letras, 2000, p. 318.

${ }^{172}$ Ibidem, p. 318-328.

173 ALMAIN, Jacques. Sobre a Autoridade da Igreja. In: BURNA, J. H.; IZBICKI, T. M. Conciliarism and Papalism. Cambridge: University Cambridge Press, 1997, p. 161.

${ }^{174}$ Ibidem, p. 161

175 Ibidem, p. 198.
} 
Assim como Bèze, que ao invocar a autoridade dos conciliaristas refere-se a ela como a parte mais sã, Almain também evoca a tradição da noção medieval da corporação no bojo da discussão conciliar quando, por exemplo, esse último compara uma mera igreja particular a um olho são que vendo o perigo do corpo, deve, por proclamação e não por exigência, designar um local que seria acessível a todos, e fazer o concílio, no caso de recusa das altas autoridades eclesiásticas, em nome da própria sanidade do corpo. ${ }^{176}$

Em Uma disputatio sobre a autoridade do concílio sobre o supremo pontífice, partindo do pressuposto evangélico que o próprio Cristo havia instituído no evangelho de Mateus, capítulo 18, segundo o qual há um dever de correção fraternal entre irmãos aos que se desviassem da boa conduta, John Mair alega que apesar de Cristo ser o melhor legislador e ter legado para sua Igreja a melhor forma de governo, entendendo-a como tal a monarquia, invariavelmente instituiu "uma cabeça [um rei], que, se ela trabalhasse para a destruição do todo, inclusive de si mesma, poderia ser cauterizada pelo resto do corpo. Primeiro, [o papa] deve ser alertado humildemente, seguindo-se o comando tão frequentemente citado no evangelho, e então se ele se mostra incorrigível, deve ser despojado do cargo de papa. Vários olhos veem mais que um só olho, e é dever deles corrigir um delinquente em sua unicidade."177

Mair reconhece a natureza de um governo monárquico no estado eclesiástico e, sem lhe desfigurar a natureza, vislumbra uma perfeita compatibilidade entre a monarquia encabeçada pelo papa e os mecanismos institucionais de representação de toda Igreja, com perfeita aptidão de controlar eventual desvio do pontífice, quando as circunstâncias assim o exigirem, pois assim assevera: "o papa é superior a qualquer indivíduo regularmente e superior a toda Cristandade, na medida em que ela está dispersa pelo mundo. Mas quando o concílio universal é reunido, este último é superior ao Romano Pontífice."178

Para vários comentadores, como J. H. Franklin ${ }^{179}$, o grande valor das teses conciliaristas seria o papel desempenhado na história do pensamento político ocidental, do período da Baixa Idade Média até o raiar da Modernidade, consistindo justamente no fato de terem sido uma das primeiras a afirmarem um lugar institucionalizado de oposição legítima, não passível de ser considerada sediciosa, a governos perversos, mas meramente restitutiva

${ }^{176}$ ALMAIN, Jacques. Sobre a Autoridade da Igreja. In: BURNA, J. H.; IZBICKI, T. M. Conciliarism and Papalism. Cambridge: University Cambridge Press, 1997, p. 198.

${ }^{177}$ MAIR, Jonh. Uma disputatio sobre a autoridade do concílio sobre o supremo pontífice. In: BURNA, J. H.; IZBICKI, T. M. Conciliarism and Papalism. Cambridge: University Cambridge Press, 1997, p. 292.

${ }^{178}$ Ibidem, p. 303.

${ }^{179}$ FRANKLIN, H. Julian. Introduction. Constitutionalism and Resistance in the Sixteenth Century: Three Treatises by Hotman, Beza \& Mornay. New York: Pegasus, 1969, p. 14. 
das legítimas funções de um governo, ou seja, uma governança que vise o bem da comunidade como um todo. Por fim, aponta-se a apropriação dessas teses pelos escritos dos calvinistas do século XVI, com o intuito de aplicá-las num ambiente secular de discussão política $^{180}$, fazendo os príncipes as vezes de papa; e o concílio, a representação de toda a comunidade política institucionalizada pelos Estados Gerais, ou o que lhes fazem as vezes em distintas realidades políticas, que, nos escritos de Hotman, Bèze e Mornay constituem um ponto pacífico e plenamente idôneo para a solução das tiranias.

\subsection{A inspiração nos Direitos Seculares Feudal e Urbano}

Dentre as fontes seculares que julgamos ser das mais importantes para o pensamento político de Bèze, sobretudo no que tange ao direito de resistência perpetrado por magistraturas inferiores e não exclusivamente pelos Estados Gerais, apontamos os desdobramentos (dentre outras fontes), daquilo que Berman denomina revolução jurídica papal $^{181}$ : os direitos seculares feudal e urbano.

\footnotetext{
${ }^{180}$ Apesar dos comentadores acima sugerirem uma transposição original das ideias conciliares para a política secular, ao fazer comparações entre a organização política secular e eclesial, importa o registro de que, em vários momentos, os conciliaristas também fizeram comparações com os reinos mundanos, o que nos leva a questionar um tanto quanto essa consideração. Em Almain já consta o registro da possibilidade dos governos seculares terem mecanismo de expurgo de seus governantes malfeitores, pois, caso a igreja em sua totalidade representada em um concílio não possa punir um papa maldoso, segue-se "que a política eclesiástica não seria tão bem ordenada como a política civil, porque seria contra a boa ordenação da vida civil não se ser capaz de remover um membro cuja conduta pode resultar na destruição do todo." (ALMAIN, Jacques. Sobre a Autoridade da Igreja. In: BURNA, J. H.; IZBICKI, T. M. Conciliarism and Papalism. Cambridge: University Cambridge Press, 1997, p. 161). Em Mair, outra comparação em relação à atuação do concílio representando toda a Igreja que, por sua, vez na linguagem bíblica também é chamada de esposa de Cristo, com o mundo secular, diz: "Se o rei da França fosse para Jerusalém e deixasse seu reino para ser administrado pelo Príncipe A., que pervertesse tudo conferindo cargos para quem não merecesse e oprimindo homens honestos, quem julgaria se a rainha [um elemento representando ainda uma parte sã do reino] agisse corretamente em resistindo àquele príncipe? De fato essa é a intenção presumida do rei. Mas como é no caso que estamos considerando: Cristo ascendeu ao Pai; Ele comissionou um vicário em seu lugar; Sua esposa é a Igreja. Se o vicário, conforme a maneira do Príncipe A. mencionado acima, procedendo incorrigivelmente, quem poderia dizer que a Igreja atuaria erroneamente ao despojar o vicário de sua autoridade?" MAIR, Jonh. Uma disputatio sobre a autoridade do concílio sobre o supremo pontífice. In: BURNA, J. H.; IZBICKI, T. M. Conciliarism and Papalism. Cambridge: University Cambridge Press, 1997, p. 293.

${ }^{181}$ Por Revolução Papal, Berman entende uma gama de práticas como cortes profissionais, leis em conjunto, uma literatura propriamente jurídica, um saber sistematizado do Direito e uma profissionalização daqueles que operavam o direito, como fruto de uma série de atitudes de auto-afirmação do papa frente ao império e aos senhorios feudais no final do século XI e início do XII. Justamente essa revolução papal traz consigo um direito secular, pois: "a Revolução Papal trouxe a existência, pela primeira vez, de um estado eclesiástico autônomo e apartado, assim como também um direito canônico separado e autônomo. Por essa mesma ação, pela primeira vez, entidades políticas sem funções eclesiásticas e ordens jurídicas não-eclesiásticas. A facção papal denominou
} 
O direito feudal fornece subsídios para a compreensão das consequências do rompimento do contrato entre o rei e seu povo, especialmente quando isso se dá por atos tirânicos do governante, permitindo assim o abandono do dever de obediência por parte do povo, já que a relação entre o povo e o soberano e seus deveres recíprocos é para Bèze análoga à do suserano com o vassalo.

Bèze é enfático ao afirmar a relação direta entre o direito feudal e sua aplicação mesmo nas relações entre governados e seus reis ou imperadores, quando versa sobre os Estados aragoneses na Espanha e sua ação perante reis contravenientes a seus juramentos, como o de perseverar na verdadeira religião: "refiro nominalmente ao direito dos feudos (entre os quais é preciso levar em conta até para Reinos e Impérios) o vassalo não deve fidelidade ao seu senhor excomungado, como está escrito no segundo livro dos Feudos, título $28, \S 1 ., 182$

H. Berman mostra que dentre os séculos XI e XIII, mais precisamente entre os anos de 1050 e 1150, os acordos feudais na Europa modificaram-se substancialmente, com a agregação de características estranhas a eles até então, como (dentre outras): objetividade, universalidade e reciprocidade dos direitos entre suserano e vassalo. ${ }^{183}$

Afere-se nesse período que os acordos feudais, anteriormente arbitrários, indefinidos, discricionários em sua eficácia local, passam a ter maior objetividade, uniformidade e generalidade, o que os fazem aspirar a uma universalidade. ${ }^{184}$

Pouco a pouco, percebia-se o surgimento de uma reciprocidade entre direitos dos senhores e dos vassalos, como também "várias formas de sujeição pessoal dos vassalos para com os senhores foram transformadas em obrigações patrimoniais, e no mesmo período, muitas formas de dominação econômica direta pelos senhores foram comutadas em impostos,

de temporal (circunscritas no tempo) e secular (mundanas) essas outras entidades políticas e seu Direito[...] O novo Direito Canônico era uno, da mesma forma a nova política eclesiástica era una [sob a batuta do pontífice romano]; mas o Direito Secular era uma multiplicidade, correspondendo a uma série de vários tipos de políticas seculares: imperial, real, feudal, senhorial, mercantil e urbana. Esses novos tipos de políticas requereram novos tipos de Direitos, até porque suas funções religiosas, seus aspectos espirituais tinham caído nas mãos de uma organização separada e independente que existia universalmente e cuja cabeça estava em Roma." BERMAN, Harold J. Law and Revolution, The Formation of the Western Legal Tradition. v. I. Cambridge, Massachusetts \& London, England: Harvard University Press, 1983, p. 50 e 273.

${ }^{182}$ BÈZE, Théodore de. Du Droit des Magistrats. Genève: Droz, 1970, p. 37. Para Kingdon, tal passagem é extraída do Consuetudines Feudorum, que faltaria na maior parte das edições modernas do Corpus Iuris Civiles, mas era recorrente em edições da época de Bèze. Outra obra da qual é muito provável que Bèze tenha se valido, segundo o pesquisador, seria uma obra sobre o direito feudal de Hotman, publicada em Lyon, no ano de 1573 De feudis commentatio tripertita. KINGDON, Robert M. Nota 8. In: BÈZE, Théodore de. Du Droit des Magistrats. Genève: Droz, 1970, p. 37.

${ }^{183}$ BERMAN, Harold J. Op. cit., p. 303.

${ }^{184}$ Ibidem, p. 303. 
franqueando aos vassalos uma substancial liberdade pessoal e econômica" ${ }^{185}$ até então inéditas, possibilitando em última análise que "mais e mais o vassalo lidasse com o feudo sem a supervisão severa e pessoal do senhor." $" 186$

Tais liberdades recém alcançadas pelos vassalos demandavam novos padrões jurídicos, o que culminou numa transição dos frouxos laços existentes num regime jurídico de direito costumeiro para uma legalização dos mesmos pela via contratual no século $\mathrm{XI}^{187}$, de modo que "virtualmente todos os direitos e obrigações do senhor e do vassalo eram dispostas pelo direito costumeiro e não poderiam ser alterados pelas partes" ${ }^{\text {"188 }}$. No conteúdo do contrato, porém, a característica mais importante e que poderia ser alterada era a previsão de retratabilidade do consentimento, já que uma das partes poderia rescindir unilateralmente o contrato, caso a outra parte não cumprisse seus deveres fundamentais. ${ }^{189}$

Tal previsão teórica surgida no século XI, com sérias repercussões de natureza prática em vários domínios da sociedade feudal, era denominada de diffidatio (retratação da fidelidade). Essa realidade jurídica introduzida pelo direito feudal aparece no primeiro tratado sistematizado do direito inglês, no ano de 1187, de Glanvill, oportunidade em que se afirma que caso um vassalo devesse ao seu senhor tanto quanto o senhor a um vassalo, e caso o senhor quebrasse a fidelidade, o vassalo ficava liberado de servir ${ }^{190}$.

Para o historiador Friedrich Heer, o diffidatio deve ser como "um ponto cardeal no desenvolvimento político, legal e jurídico da Europa. Toda ideia de um direito de resistência é própria dessa noção de um contrato entre o governante e o governado, entre o superior e o inferior" ${ }^{\prime 191}$, permitindo dessa forma um mínimo de igualdade entre as partes por mais díspares que fossem na realidade, embora essa igualdade tivesse as limitações inerentes a toda igualdade formal que um contrato pode suscitar.

O direito urbano deve ser compreendido como um dos pilares que constituem, legitimam e fornecem elementos para o exercício do direito de resistência perpetrado pelos magistrados inferiores, nos termos da teoria de Bèze.

185 BERMAN, Harold J. Law and Revolution, The Formation of the Western Legal Tradition. v. I. Cambridge, Massachusetts \& London, England: Harvard University Press, 1983, p. 304.

${ }^{186}$ Ibidem, p. 305.

${ }^{187}$ Ibidem, p. 305.

${ }^{188}$ Ibidem, p. 305.

${ }^{189}$ Ibidem, p. 305.

${ }^{190}$ Ibidem, p. 306-307.

${ }^{191}$ HEER, Friedrich. The Medieval Europe, 1100-1350. New York: Penguin, 1961, p. 37 apud BERMAN, Harold J. Law and Revolution, The Formation of the Western Legal Tradition. v. I, Cambridge, Massachusetts \& London, England: Harvard University Press, 1983, p. 307. 
Harold Berman mostra que no final do século XI e no transcorrer do XII, em várias partes da Europa, surgem milhares de novas cidades. Tais entes políticos "eram algo intermediário" daquilo que foram as cidades gregas auto-suficientes, ou os centros de controle administrativo governados por oficiais em nome de uma autoridade central, como eram no império romano. ${ }^{192}$

Para o historiador do Direito ora referido, tais cidades e vilas se consolidaram antes mesmo que as regiões onde estavam localizadas se tornassem unidades políticas integradas (como Castela, Aragão, Flandres, Normandia, ducados germânicos, França, dentre outros), sendo inclusive possível afirmar que, por mais diversas que fossem suas características, "todas tinham a consciência de si mesmas como comunidades urbanas e tinham instituições legais similares: todas eram governadas por um sistema de direito urbano." 193

Dentre os diversos fatores que otimizaram a eclosão do fenômeno urbano europeu, destacam-se fatores jurídicos associados à revolução papal, que possibilitaram novas práticas, conceitos e instituições "concernentes a comunas e outras tipos de associações fraternais, juramentos coletivos, personalidade corporativa, cartas de liberdade, participação na elaboração das leis, governo representativo e a própria ideia de Estado."194

A emergência de tais práticas jurídico-político-administrativas demandou o surgimento de novos atores políticos, que a nosso ver seriam os magistrados inferiores, com poderes de operacionalizá-las, Bèze cita textualmente estes magistrados em seu tratado de 1574, como sendo os oficiais eletivos das cidades como Prefeitos, Vigários, Síndicos, Escrivães, dentre outros. ${ }^{195}$ Além do mais, nosso autor deixa claro que os reis da França ao se sagrarem governantes prometem respeitar os "privilégios das cidades"196

Apesar de reféns do jogo de forças perpetrado pelos bispos na defesa de suas prerrogativas jurisdicionais sobre as cidades, e pelos reis da França objetivando a centralização política, Berman aponta um fortalecimento dessas magistraturas urbanas das regiões francesas, ao diagnosticar concessões que lhes foram feitas tanto pelo soberano francês, quanto pelos representantes católicos principais da região. Como exemplos dessa

192 BERMAN, Harold J. Law and Revolution, The Formation of the Western Legal Tradition. v. I, Cambridge, Massachusetts \& London, England: Harvard University Press, 1983, p. 357

193 Ibidem, p. 357.

${ }^{194}$ Ibidem, p. 363.

195 BÈZE, Théodore de. Du Droit des Magistrats. Genève: Droz, 1970, p. 6 e 18.

196 Ibidem, p. 42. 
realidade pode-se citar que, apesar de Filipe Augusto em 1210 ter proibido, por uma ordenança real, a prisão de funcionários da Coroa (salvo se fossem pegos em flagrante na realização de um crime, e mesmo assim deviam ser entregues a jurisdição episcopal em muitos casos), progressivamente a própria autoridade real vai reconhecendo o direito dos municípios a julgar crimes capitais e de média e baixa justiça ${ }^{197}$.

Quanto a concessões episcopais à autoridade das magistraturas locais, Berman narra o exemplo da cidade de Laon, que dentro do espírito da Concordata de Worms (1122) chegou a um acordo de reconhecimento da jurisdição superior do bispo, que devia designar os juízes locais (échevins); “mas o prefeito e os 'jurados' (jurati, jures, ou comprometidos por juramentos, equivalente aos pares de Beauvais e outros municípios) também tinham jurisdição de fazer valer os costumes da cidade e suprir a justiça quando a episcopal falhasse." ${ }^{198}$ Além disso, nessa mesma municipalidade, e em outras cidades onde havia magistrados designados por bispos, esses foram gradativamente se convertendo em magistrados puramente municipais e, no final do século XII, já eram simplesmente eleitos pelos "jurados""199, ou seja, não obstante as limitações no exercício do poder pelos magistrados das municipalidades graças a intromissões de autoridades feudais, episcopais e da realeza, "restava uma substancial autonomia de jurisdição da comuna sobre seus próprios membros e um consistente corpo de um direito comunal autônomo e distinto" 200 de modo que "em todo lugar [na Europa] um diminuto grupo de homens, nomeados pelos principais cidadãos e eleitos pelo povo todo compunham a magistratura" ${ }^{, 201}$ das cidades.

Dentre as cidades que mais se prestaram como paradigma para novas leis, magistraturas e instituições está a cidade de Magdeburgo $^{202}$, cujas ações de resistência (entendidas como um verdadeiro droit) perpetradas por seus magistrados e cidadãos foram

197 BERMAN, Harold J. Law and Revolution, The Formation of the Western Legal Tradition. v. I, Cambridge, Massachusetts \& London, England: Harvard University Press, 1983, p. 367.

${ }^{198}$ Ibidem, p. 368.

${ }^{199}$ Ibidem, p. 368

${ }^{200}$ Ibidem, p. 367.

${ }^{201}$ Ibidem, p. 368.

202 Ainda sobre o surgimento de um direito urbano no período da Baixa Idade Média e o respectivo fortalecimento dos "magistrados inferiores" das diversas regiões da Europa em cidades como a de Bruges, Montauban, Ipswich, etc., cumpre registrarmos a descrição de Berman sobre o exemplo de que "a mais caricatural ilustração do nascimento e desenvolvimento do sistema de direito urbano nas entranhas da tradição jurídica ocidental seja o processo pelo qual os direitos de mais de doze cidades importantes da Alemanha foram formalmente recebidos por centenas de novas cidades fundadas entre os séculos XII e XIV. A título de exemplo, as leis de Lübeck foram recebidas em quarenta e três cidades, as de Frankfurt em quarenta e nove, as de Hamburgo em quatro, as de Freiburgo por dezenove, as de Munique por treze, as de Bremen por duas, as de Braunschweig por três. Porém, a mais importante fora a disseminação das leis de Magdeburgo, uma cidade às margens do rio Elba, para mais de oitenta novas cidades. O Recht de Magdeburgo transformou-se na base predominante do Direito Escrito da Europa Central e Oriental” BERMAN, Harold J. Op. cit., p. 376. 
inspiradoras e celebradas por Bèze em sua obra de 1554, Da punição dos hereges pelo magistrado civil, como também vinte anos depois em Du Droit des Magistrats.

\subsection{Um Importante Precedente: A Cidade de Magdeburgo e sua Confissão, de 1550, rememorada por Bèze em Da punição dos hereges pelo magistrado civil, de 1554}

A obra Da punição dos hereges pelo magistrado civil de 1554, em que Bèze desenvolve uma defesa da prerrogativa e do dever dos magistrados civis punirem exemplarmente as heresias, como havia sido feito em Genebra, quando Calvino instigou a cruenta execução de Michel Servet na fogueira, constitui uma das primeiras de caráter polêmico publicadas por nosso autor, sendo também uma refutação categórica das teses de tolerância elaboradas por Sébastien Castellion. ${ }^{203}$

No transcorrer da obra, Bèze, ao desenvolver sua argumentação para definir a natureza do governo civil e as relações entre as diversas instâncias de um governo, sugere a existência do direito e dever dos magistrados inferiores de resistir aos magistrados superiores, na medida em que for necessário defender a verdadeira religião, oportunidade na qual faz referência ao "desafio da cidade de Magdeburgo, em face das tentativas do governo imperial de impor a toda Alemanha o compromisso religioso de 1548 conhecido sob o nome d’Intérim [Augsburgo]",204.

No tratado de 1554, Bèze louva o exemplo da cidade alemã às margens do rio Elba, após descrever "o dever do Magistrado inferior que é de manter, tanto quanto lhe seja possível, em seu país ou em sua jurisdição a pureza da religião, embora deva proceder com prudência e boa moderação.[...] E disto a cidade de Magdeburgo mostrou no nosso tempo um exemplo bem notável [...]". ${ }^{205}$ Oportunidade na qual desqualifica qualquer oponente no debate sobre a atuação desses magistrados ao exortar: "eu digo, no entanto, que quem quer que seja que estime que seja necessário deixar de usar a ajuda dos magistrados cristãos que Deus

\footnotetext{
${ }^{203}$ KINGDON, R. Introduction. In: BÈZE, Théodore de. Du Droit des Magistrats. Genève: Droz, 1970, p. VIIVIII.

${ }^{204}$ Ibidem, p. VIII.

${ }^{205}$ BÈZE, Théodore de. De haereticis a civili magistratu puniendis. (1554). (Apêndice I) In: BÈZE, Théodore de. Du Droit des Magistrats. Genève: Droz, 1970, p. 69.
} 
provê, contra a violência externa dos infieis ou dos heréticos, que despoja a Igreja de Deus de um socorro maravilhosamente útil e mesmo necessário[...]"206.

Historicamente, a cidade de Magdeburgo, que se notabilizara com os eslavos como um centro comercial, no ano de 968 torna-se um arcebispado, posteriormente uma base militar defensiva de ataques perpetrados por eslavos e apenas no raiar dos anos de 1100 é que a cidade desenvolveu de forma contínua suas instituições legais e de governo, assim como uma própria consciência cívica. ${ }^{207}$

Antes dos eventos referidos por Bèze em sua obra de 1554, que estavam associados com a reforma protestante na Alemanha, a cidade já havia tido um marco inicial de tradição de insurgência contra autoridades tidas por superiores no seu contexto histórico, do ano de 1129, quando um levante armado de seus cidadãos é deflagrado contra o arcebispo, e ainda que frustrado pelo dirigente da Igreja Católica da região, "nesse ano também a expressão maiores civitas (cidadãos principais) pela primeira vez aparece num documento de Magdeburgo."208

Sobre a cronologia do desenvolvimento institucional das magistraturas de Magdeburgo, Berman aponta que nos anos de 1160 surgem referências aos "oficiais e juízes da cidade de Magdeburgo", e no ano de 1183, a referência aos oficiais da corte aparece pela primeira vez, até que "finalmente em 1188, o arcebispo de Wichman reformou o governo da cidade, mantendo o administrador hereditário (Burggraf) e um delegado do governo hereditário (Schultheiss), mas também estabeleceu um conselho de doze homens, consistindo de onze oficiais vitalícios e um Schultheiss. O arcebispo, que governava toda a arquidiocese, ainda que mantivesse o poder de controle final sobre a cidade, conservara a autonomia da cidade na administração da justiça, impostos e problemas conexos."

Posta essa realidade histórica que antecedeu a Reforma, talvez não seja de se surpreender a eclosão do levante protestante contra o imperador, justificado pela confissão de seus pastores, nessa cidade que cultuara suas prerrogativas institucionais.

A confissão de Magdeburgo (ou: A confissão de Magdeburgo e apologia dos pastores e outros ministros da Igreja em Magdeburg), de 1550, escrita por Nicolas Von Amsdorf e mais oito ministros luteranos notórios, é um texto no qual, segundo Skinner,

\footnotetext{
${ }^{206}$ BÈZE, Théodore de.De haereticis a civili magistratu puniendis. (1554). (Apêndice I) In: BÈZE, Théodore de. Du Droit des Magistrats. Genève: Droz, 1970, p.60-70.

${ }^{207}$ BERMAN, Harold J. Law and Revolution, The Formation of the Western Legal Tradition. v. I, Cambridge, Massachusetts \& London, England: Harvard University Press, 1983, p. 376.

${ }^{208}$ Ibidem, p. 376.

${ }^{209}$ Ibidem, p. 376-377.
} 
inicia-se uma quebra do modelo que luteranos e calvinistas vinham seguindo de nãoresistência, constituindo "a primeira enunciação formal de uma teoria de resistência pela força”. Porém, na verdade, esse documento nada mais fez do que ter por argumento central teses já desenvolvidas anteriormente por juristas de Hesse (1529) e reiteradas por outros juristas luteranos como Bucer e Osiander ${ }^{210}$.

Como tese fundamental, o texto enuncia que: "quando um magistrado superior perseguir seus súditos, o magistrado inferior, pela lei da natureza divina e pela verdadeira religião e reverência a Deus, deve conforme ordem do próprio Deus resistir-lhe" ${ }^{, 211}$, de modo que toda vez que um magistrado instituído por Deus passar a honrar as coisas más e aterrorizar às boas não pode ser mais considerado uma autoridade instituída por Deus.

Conclusão esta que poderia levar a uma interpretação imediata de que o magistrado tirano poderia ser considerado um criminoso comum por parte de qualquer particular, o que fatalmente levaria a uma radicalização do movimento de reforma, algo que seus líderes também não desejavam.

Skinner aponta como solução para esse problema a apresentação no documento de "uma engenhosa combinação de argumentos de direito privado com a teoria dos magistrados inferiores", esta última de natureza claramente constitucional. ${ }^{212}$ Salienta-se, primeiro, que o agente da resistência aja conforme "seu lugar e em razão de sua função", assim como "a pessoa de função mais próxima à do supremo magistrado é outro magistrado", e que mesmo essa condição de inferioridade daquele que trilha os caminhos perversos, este também é instituído por Deus para "a honra das boas obras e terror das más",213, permitindo portanto a conclusão coerente com as escrituras (especialmente a exortação de São Paulo) de que deve caber tão somente a essas autoridades resistir a quaisquer outros magistrados que estão agindo fora dos limites de seus cargos.

Outra contribuição da Confissão consiste no esmiuçamento dos graus de injúrias “atrozes e notórias" 214 , que devem ser considerados motivos para justificar a resistência.

Um primeiro grau de injúria seria se por descuido um magistrado superior, num acesso de cólera inflige a injúria. Isso não justificaria a resistência dos inferiores. ${ }^{215}$

\footnotetext{
${ }^{210}$ SKINNER, Quentin. As fundações do pensamento político. São Paulo: Cia das Letras, 2000, p. $482-483$.

211 AMSDORF, Nicolas von et. al. A confissão de Magdeburgo e apologia dos pastores e outros ministros da Igreja em Magdeburgo, apud SKINNER, Quentin. As fundações do pensamento político. São Paulo: Cia das Letras, 2000, p. 482-483.

212 SKINNER, Quentin. Op. cit., p. 493.

${ }^{213}$ AMSDORF, Nicolas von et.al. Op.cit., p. 493.

${ }^{214}$ Ibidem, p. 493.

${ }^{215}$ Ibidem, p. 493.
} 
Um segundo grau seria a colocação da vida de um homem ou de seus familiares em risco por força injusta; ainda que seja uma injúria de natureza atroz e notória, é recomendável um sofrimento paciente. ${ }^{216}$ Como terceiro grau: a situação na qual um magistrado inferior comete um pecado, compelido pelo superior; apesar de atroz, ainda não justificaria a resistência pela força. ${ }^{217}$

Porém, no quarto e último grau de injúria, resta indubitável a licitude da resistência quando um governante "continuamente e de modo deliberado, tenta destruir as boas obras de todos". ${ }^{218}$ Nesse caso, os magistrados inferiores devem opor-se a tais governantes, em defesa da piedade e do bom governo.

Destaca-se o expediente desses teólogos-juristas, de que justamente no quarto grau de injúria, apesar de conter o elemento de reiteração dos atos ímpios, o conteúdo "tentar destruir as boas obras de todos" deixa um comando extremamente decisivo, quando comparado com os graus anteriores tão particulares.

Uma importante atribuição à Confissão - que indiscutivelmente pertence à tradição luterana, não representando um rompimento drástico com ela, principalmente pelo fato de se valer da teoria dos dois reinos e expressamente o documento alegar sua inspiração nos escritos do Dr. Martinho Lutero, principalmente a obra Advertência do Dr. Martinho Lutero a seus estimados alemães, do início da década de 1530, único escrito citado na Confissão, além das escrituras ${ }^{219}$ - seria, segundo Carter Lindberg, o escrito dos pastores de Magdeburgo em 1550, uma prova de rechaço ao lugar comum de vinculação do desenvolvimento do nazismo com a ideia de sujeição às autoridades pregada pelo luteranismo $^{220}$, uma das bases dos elementos culturais da nação alemã.

Talvez uma prova que ampara a afirmação de Lindberg seja a bela descrição feita por Lionel Richard, do movimento Bandeira Nacional, oriundo de Magdeburgo que, em honra das boas tradições constitucional-republicanas da cidade, fez uma última tentativa e, possivelmente, a mais veemente, de por a salvo a República de Weimar da degeneração

\footnotetext{
${ }^{216}$ AMSDORF, Nicolas von et. al. A confissão de Magdeburgo e apologia dos pastores e outros ministros da Igreja em Magdeburgo, apud SKINNER, Quentin. As fundações do pensamento político. São Paulo: Cia das Letras, 2000, p. 493.

${ }^{217}$ Ibidem, p. 493-494.

${ }^{218}$ Ibidem, p. 493-494.

${ }^{219}$ WHITFORD, David Mark. Tyranny and Resistance, The Magdeburg Confession and The Lutheran Tradition. Saint Louis: Concordia Publishing House, 2001, p. 77.

${ }^{220}$ LINDBERG, Carter. Prólogo. In: WHITFORD, David Mark. Op. cit., p. 9.
} 
nazista, inclusive com apelo às armas, contra os atos violentos que o partido de Hitler perpetrava. $^{221}$

\subsection{Uma primeira sistematização do pensamento político de resistência em Bèze: Confession de la foi chrestienne, em 1560}

A Confession de la foi chrestienne foi escrita em francês no final de 1558, com uma primeira edição no ano seguinte ${ }^{222} \mathrm{e}$, posteriormente, no ano de 1560 , uma outra em latim consideravelmente revista e aumentada. Tal obra pretendeu abordar a doutrina reformada em sete pontos, sendo que o ponto V, sobre A Igreja, é finalizado por duas seções sobre o governo civil. A temática da segunda seção é o problema da resistência. ${ }^{223}$

Entendemos que tal temática é travestida ainda de um vocabulário mais teológico, vinculada muitas vezes a uma preocupação extremamente moralizante da discussão política, sobretudo, conforme veremos, mas já citamos a título de exemplo, quando Bèze se ocupa em expor as motivações em tonalidades quase psicológicas, que levam a uma tirania manifesta, quando o vício reside no coração daquele que apesar de ter ascendido ao poder de forma legítima ou alcançado a legitimação a posteriori de seu poder pelo consentimento, se entrega à impiedade, à avareza, à ambição e a outros vícios.

Entretanto, entendemos que a discussão de fundo do trecho da obra de 1560 já aponta para a questão das espécies de tiranias, consagrada pela tradição bartolista, que

\footnotetext{
221 "Os jovens operários ou os estudantes que desejam ser mais eficazes, preocupados especialmente com as atividades da extrema direita, juntam-se à Jovem Bandeira, seção juvenil da Bandeira Nacional. Essa organização de massa, fundada em 1924 em Magdeburgo, tinha como programa a defesa de instituições republicanas. Era uma réplica dos Capacetes de Aço. Originalmente, fora concebida também como uma associação de antigos combatentes. O Zentrum e o Partido Democrata tinham tomado parte na sua fundação, depois se haviam afastado dela. Desde o início, sua animação coubera aos social-democratas, que a consideravam um pouco como a sua milícia. Em 1930, eles criaram até uma tropa de elite, as formações de proteção, que tinham por tarefa responder, quando era preciso, às violências dos nazistas. E em 1931 eles a integraram, juntamente com a União Geral dos Sindicalistas e as associações de ginástica que controlavam, à Frente de Ferro, organizada nas empresas em grupos de autodefesa." RICHARD, Lionel. A República de Weimar, São Paulo: Cia das Letras, 1988, p. 134.

${ }^{222}$ Nessa versão de 1559 , Kingdon aponta um retrocesso das ideias de Bèze no que tange ao arrojo do direito de resistência que havia ensaiado, em 1554, com a edição de Da punição dos hereges pelo magistrado civil e das ideias que desenvolverá nos anos de 1570, uma vez que "Na edição de 1559, as ideias de Bèze sobre o problema da resistência são banais, extraídas do ensinamento tradicional do cristianismo. Conclama-se a todo sujeito cristão à obediência completa e indiscutível aos seus mestres e os exorta à desobediência passiva quando um magistrado o força a agir contra a vontade de Deus. Mas fica fora de questão a resistência ativa, mesmo em caso de tirania." KINGDON, R. Introduction. In: BÈZE, Théodore de. Du Droit des Magistrats. Genève: Droz, 1970 , p. IX.

${ }^{223}$ KINGDON, R. Op. cit., p. IX.
} 
classifica as tiranias como de origem e manifesta, classificação que também será utilizada no tratado Du Droit des Magistrats ${ }^{224}$.

Nesta segunda versão de seu catecismo da fé renovada, no ponto acima referido, em seu artigo XLV, Da obediência devida aos magistrados, Bèze inicia a questão em tons prudentes, consignando o paralelismo necessário a ser acatado por qualquer cristão do mesmo dever de obediência à ordenação de Deus e aos magistrados, assim como finaliza o artigo denunciando nominalmente os anabatistas, por sua postura considerar ilícitos atos civis como os julgamentos e as guerras por si só, e que de forma alguma suas ideias possam ser confundidas com "essas fantasias estranhas e perversas",225.

Censurando a alegação corrente daqueles que promovem sedições de que elas se justificariam graças aos vícios dos magistrados, Bèze declara ser "necessário olhar se o vício está na coisa simplesmente ou se está na pessoa."226

Por vício da coisa entende-se uma dominação, ou poder por si mesmo ser condenado por Deus, ou ainda quando tal coisa é "contrária às leis e o estado de certa República."227

Um exemplo de vício na coisa, citado por nosso autor é o de Júlio César, que apesar de ser um homem bom em vários sentidos, postulou o consulado, pegando em armas contra os cônsules, embora as leis da República romana proibissem a usurpação do poder real. "Em suma, ele derruba o estado da República." 228 e, dessa forma, naquela oportunidade, era irrepreensível a resistência oferecida pelos cônsules contra César, pois se estava claramente diante uma situação de se instituir uma tirania de origem.

Porém, nosso autor aventa a possibilidade de os vícios intrínsecos às coisas poderem algumas vezes ser sanados, a exemplo ainda de Júlio César, que quando obteve os "comandos da soberana dominação e em sinal de salvaguarda [de tal aquisição], foi armado de poder tal qual anteriormente teriam tido os defensores do povo que se chamavam Tribunos

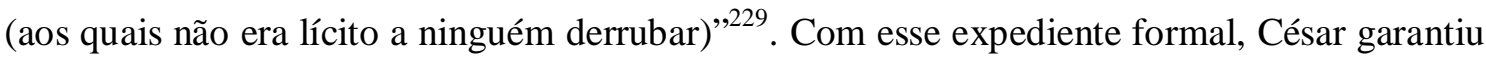
para si a convalidação de seu golpe institucional, de tal modo que os seus opositores, que de início licitamente resistiram às suas pretensões, posteriormente passaram a dever obediência a

${ }^{224}$ BARROS, Alberto Ribeiro de. A teoria da soberania de Jean Bodin. São Paulo: Ed. Unimarco e Fapesp, 2001, p. 272-273.

${ }^{225}$ BËZE, Théodore de. Confession de la foi chrestienne. $2^{\circ}$ version (1560 et ss.). Point V, article XLV. (Apêndice II). In: BÈZE, Théodore de. Du Droit des Magistrats. Genève: Droz, 1970, p. 75.

${ }^{226}$ Ibidem, p. 75

${ }^{227}$ Ibidem, p. 70.

${ }^{228}$ Ibidem, p. 71.

${ }^{229}$ Ibidem, p. 71. 
César e seus sucessores ${ }^{230}$, que acabaram por estabelecer um sistema autocrático de poder no Principado.

Em outras palavras, para o sucessor de Calvino em Genebra, um meio legítimo pode alterar o status vicioso de uma coisa, como a usurpação política, desde que haja um consentimento expresso, tácito ou ratificado ${ }^{231}$.

Neste ponto de sua Confissão, importa-nos registrar que, diferentemente de sua posição em Du Droit de Magistrats de 1574, Bèze aponta uma maior flexibilidade para convalidação de uma tirania de origem, por tolerar o consentimento tácito, mas na obra posterior, considera que o consentimento deve ser expresso. ${ }^{232}$

No que tange ao vício das pessoas, Bèze entende que existem dois tipos: "o vício é exterior e principalmente sobre a pessoa" ou "o vício reside no interior da pessoa". 233

Bèze relaciona o primeiro tipo de vício àqueles que, contrariando leis e estatutos, "se fazem eles mesmos Magistrados por violência ou oprimindo povos estrangeiros." ${ }^{234}$ Neste caso, Bèze entende que os magistrados inferiores têm o dever de por a salvo aqueles que estão sob seu encargo, ou seja a parcela do povo sob sua jurisdição, e inclusive estende tal poder "contra os opressores tanto domésticos, dizendo melhor, do país, quanto os estrangeiros."235 , tratando-se, aqui, de uma tirania de origem.

Se por acaso houver por parte desses magistrados descumprimento de seu dever de combate aos opressores, ou covardia, ele abandonar a República, somando-se isso a outro requisito, que seria uma vocação extraordinária aberta por Deus, sem "leviandade ou afetação

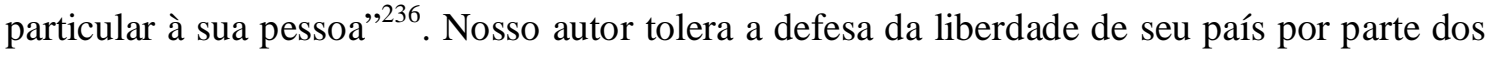
particulares, colocando nessas condições, e tão somente nelas, uma obrigação solidária entre magistrados inferiores e particulares para evitar tiranias de origem.

Ao tratar a segunda espécie de vício das pessoas, Bèze descreve tal malefício como aquele que "reside no interior", fazendo com que príncipes que chegaram ao poder devidamente, por leis ou estatutos, ou mesmo por consentimento tácito ou expresso (referindo-se a uma tirania de origem sanada), manifestem "impiedade, avareza, ambição,

${ }^{230}$ BÈZE, Théodore de. Confession de la foi chrestienne. $2^{\circ}$ version (1560 et ss.). Point V, article XLV. (Apêndice II). In: BÈZE, Théodore de. Du Droit des Magistrats. Genève: Droz, 1970, p. 72-73.

${ }^{231}$ Ibidem, p. 72.

${ }^{232}$ BÈZE, Théodore de. Du Droit des Magistrats. Genève: Droz, 1970, p. 13-14 e 16.

${ }^{233}$ Ibidem, p. 73.

${ }^{234}$ Ibidem, p. 73.

${ }^{235}$ Ibidem, p. 73.

${ }^{236}$ Ibidem, p. 73. 
crueldade, dissolução, obscenidades e outros monstros que os Tiranos estão acostumados a carregar em seus corações" ${ }^{237}$, ou seja, trata-se de uma tirania manifesta.

Nesse caso, a solução vislumbrada seria o socorro a um poder acima do tirano. O autor aponta, em seu tempo, a competência dos sete eleitores, no caso do Sacro Império Romano Germânico, assim como a existência, em quase todas as monarquias, dos "Estados do Reino" que "são obrigados a reprimir os Tiranos que se excedem e querem exercer sua fúria" $^{238}$.

Porém, diferentemente do caso de uma tirania de origem, quer pelo vício residir na coisa, ou sobre a pessoa, em que os magistrados inferiores estão aptos a resistir, no caso de uma tirania manifesta, a solução é mais restrita, pois somente os Estados-Gerais poderão atuar.

Em suma, percebe-se que, em seu catecismo de 1560, Bèze arquiteta os principais tópicos a serem abordados e ampliados em seu tratado de 1574, ainda que com alterações de conteúdo, sendo a mais importante a desautorização de se habilitar magistrados inferiores para o combate às tiranias manifestas. Porém, apesar dessa limitação, tal obra, publicada no início das guerras de religião na França, serviu como um norte para reformadores de várias partes da Europa, sobre esse problema tão crucial e de fácil consulta pela sistematização que Bèze faz em sua Confession ${ }^{239}$.

${ }^{237}$ BÈZE, Théodore de. Confession de la foi chrestienne. $2^{\circ}$ version (1560 et ss.). Point V, article XLV. (Apêndice II). In: BÈZE, Théodore de. Du Droit des Magistrats. Genève: Droz, 1970, p. 74. ${ }^{238}$ Ibidem, p. 74.

${ }^{239}$ KINGDON, R. Introduction. In: BÈZE, Théodore de. Du Droit des Magistrats. Genève: Droz, 1970, p. IXXII. 


\section{CAPÍtUlO III - A PLENITUDE DO ARGUMENTO CONSTITUCIONAL EXPRESSO EM DU DROIT DES MAGISTRATS SUR LEURS SUJETS}

A obra do Du Droit des Magistrats, escrita por Bèze entre junho e julho de $1573^{240}$, ainda sob o impacto da noite de São Bartolomeu, promove mudanças qualitativas e profundas no pensamento de Bèze e em seus escritos.

Para R. Kingdon, os massacres de São Bartolomeu são um divisor de águas no engajamento político de Bèze, uma vez que num primeiro momento nosso autor "poderia aparentemente convencer-se a si mesmo e a seus discípulos de que a guerra realizada pelos huguenotes não era verdadeiramente dirigida contra governo legal." ${ }^{241}$. Isso por duas razões. A primeira, pelo fato de a guerra ser dirigida contra os maus conselheiros de primeiro escalão, os Guise, que haviam sequestrado a família real e governavam de fato, em detrimento do legítimo soberano. Uma segunda razão que desautorizava a sublevação era que o objetivo da guerra seria fazer respeitar o édito do soberano de janeiro de 1562, que concedia certa liberdade de culto aos protestantes, só que vinha sendo flagrantemente desrespeitado pelos Guise e outros oficiais do governo. Em razão disso, aqueles que violassem as leis do reino deveriam ser punidos, ainda que o preço fosse uma guerra. ${ }^{242}$

Mas a série de massacres ocorrida entre agosto e setembro de 1572 leva Bèze a repensar os fundamentos do direito de resistência, uma vez que os assassinatos do almirante de Coligny e de outras lideranças políticas do partido protestante que desencadearam os massacres haviam sido ordenados pelo próprio Charles IX, dominado por sua mãe e seu irmão mais jovem, Henri d' Anjou, de tal forma que não se podia mais persistir na acusação das perseguições contra os protestantes serem de responsabilidade apenas dos conselheiros maldosos, pois em tais eventos, eles apenas executaram pura e simplesmente a ordem de um governante legítimo. "Essa novidade forçou Bèze e outros a reconsiderar o problema da resistência, e ela levou a Du Droit des Magistrats."

\footnotetext{
${ }^{240}$ A precisão do intervalo de escrita do tratado entre os dois meses referidos trata-se de uma inferência de Kingdon, devido às referências no tratado da eleição real na Polônia, neste mesmo ano, assim como o fim do intervalo do período de composição do tratado ser mais facilmente identificável, uma vez que em 30 de julho Bèze apresenta a versão final ao Conselho genebrino, pedindo autorização para publicá-la. KINGDON, R. Introduction. In: BÈZE, Théodore de. Du Droit des Magistrats. Genève: Droz, 1970, p.. XXVI.

${ }^{241}$ Ibidem, p. XIII.

${ }^{242}$ Ibidem, p. XIII.

${ }^{243}$ Ibidem, p. XIII. Para Patricia Hills Finlayson, talvez um dos motivos imediatos para que Bèze escrevesse o tratado de 1574 seria o fato de em 03 de Dezembro de 1572, as cidades huguenotes de La Rochelle, Montauban e Sancerre terem se decido por oferecer resistência ao cerco das tropas reias, e, portanto, se beneficiariam de uma
} 
É muito provável que Bèze tenha redigido seu tratado primeiro em latim, já que tinha o hábito de escrever em latim e conferir aos cuidados de terceiros a versão de seus escritos para o francês. Além disso, os registros do Conselho de Genebra atestam a apresentação da obra sob o título De jure magistratuum, para obter-se a publicação. ${ }^{244}$

As duas versões, latina e francesa, praticamente correspondem "palavra por palavra" uma à outra, e a única "diferença entre os dois textos consiste em uma série de títulos que subdivide o texto em latim em vários capítulos, cortando o fluxo ininterrupto da versão francesa, fazendo melhor sobressair a estrutura lógica do tratado de Bèze."245

Quanto à recepção do tratado pelo conselho genebrino, percebe-se o tom de cautela que proíbe a publicação, por questões de segurança da própria cidade, ainda que não faça qualquer restrição ao conteúdo da obra, conforme se atesta nas atas do Conselho de Genebra, no volume 68, às folhas 163, em 10 de Agosto de 1573:

Teodoro de Beza. O Senhor Síndico Varro, o senhor Lugar-tenente, o senhor Rosset, etc, tendo lido o livro Do direito dos magistrados, apresentado ultimamente por ele, consideraram que, embora não contenha senão a verdade, todavia, presentemente, não lhes parece bom que seja impresso, tanto mais por que seria muito escandaloso e poderia causar muitas perturbações e emoções das quais esta cidade seria sobrecarregada, até mesmo pelo seu estilo. O senhor Teodoro de Beza é bastante conhecido. Posto isto, foi decretado que se informe onde ele foi impresso, e que se inquira para se castigar o editor e confiscar as cópias. ${ }^{246}$

Tais temores exigiram de Bèze e dos editores a cautela de fazer a obra aparecer de forma anônima e mesmo confusa quanto à sua origem. As primeiras edições foram em língua francesa, que cuidadosamente disfarçam a origem da publicação. E. Droz, por meio de estudos tipográficos, aponta que tais edições no ano de 1574 se deram em Heidelberg, sob o encargo de Jean Mareschal e outra em Genebra, sob responsabilidade de Jacob Stoer. Entretanto, a folha de rosto dessas primeiras edições fora cuidadosamente elaborada para

justificativa teórica para embasarem tal decisão. FINLAYSON, Patricia Hills. Resistance Theory in Du Droit des Magistrats. Tese Inédita. University of Minnesota, 1965, p. 7.

${ }^{244}$ KINGDON, R. Introduction. In: BĖZE, Théodore de. Du Droit des Magistrats. Genève: Droz, 1970, p. XXVIII.

${ }^{245}$ Ibidem, p. XXXIV.

${ }^{246}$ Excertos dos Registros do Conselho de Genebra, sobre a impressão de Du Droit des magistrats e Des Mémoires de l' estat de France sous Charles neufiesme. (Apêndice III). BÈZE, Théodore de. Du Droit des Magistrats. Genève: Droz, 1970, p. 76. 
enganar as autoridades, ao estampar os dizeres: "publicado por aqueles de Magdeburgo no ano de MDL e agora revisto e aumentado de mais razões e exemplos". Ou seja, tentara-se fazer a obra passar como uma revisão da Confissão de Magdeburgo. Porém, apesar desse esforço de se tentar fazer com que o tratado de Bèze aparecesse como uma mera revisão da Confissão de Magdeburgo, ao ser confrontado com a Confissão, mostra-se "mais longo e mais elaborado, seus exemplos possuem outras fontes, enfim suas razões, bases do tratado, são sensivelmente diferentes". 247

Uma questão preliminar, antes de adentrarmos na análise da obra, objeto da presente dissertação, seria fazermos alguns esclarecimentos e apontar os problemas relativos às expressões constitucionalismo ou constitucional, e seu uso para qualificar o direito político de resistência nos tratados calvinistas do século XVI.

J. H. Franklin aponta para uma transformação de costumes e teses entre o período medieval e a modernidade, na pena de autores monarcômacos, de modo a anteciparem ideias e práticas que apenas o século XVII ou XVIII conheceriam, e que constituem um elo importante na evolução da própria noção de constitucionalismo:

O componente constitucional parece ser não apenas o mais interessante mas também o aspecto mais profundo de seu pensamento desde que sua doutrina de resistência se propôs a isso. E apesar dos monarcômacos lastrearem substancialmente seus tratados na fórmula constitucional medieval, seu uso dessa tradição envolve uma ênfase e novas conexões que são caracteristicamente modernas em seu tom e claramente antecipa ideias que nós normalmente associamos à afirmação da supremacia parlamentar na Inglaterra no século seguinte. Em minha visão, portanto, isso se justifica, pois o pensamento político dos monarcômacos é uma importante transição do movimento constitucional medieval para o moderno, e além disso pesquisar sua contribuição nos daria uma compreensão clara de como essa transição se deu e quais alterações ela envolveu. ${ }^{248}$

Além disso, nos termos de minucioso estudo de Harro Höpfl, historicamente o surgimento da expressão lei fundamental, sinônimo nos dias atuais de constituição, pode ser

${ }^{247}$ KINGDON, R. Introduction. In: BÈZE, Théodore de. Du Droit des Magistrats. Genève: Droz, 1970, p. XXXI.

248 FRANKLIN, Julian H. Constitucionalism and resistance in the sixteenth century: the protestant monarchomachs. In: SPITZ, David. Political Theory and Social Change. New York: Atherton, 1967, p. 117. 
em muito atribuído ao nosso autor, na medida em que ele diz haver leis postas na ocasião da fundação da monarquia francesa, no sentido de controlar os governantes. Bèze associa as expressões "as boas leis e condições nas quais o estado público é fundado" e "direito público e concernente ao estado" de tal modo a expressar que "a sobrevivência do estado depende da manutenção das boas velhas leis e antigas leis de controle dos príncipes e dos súditos [...]"249.

Dessa forma pode-se afirmar a existência de uma consolidada tradição de comentadores (como Benert, Franklin, Kingdon, Skinner, dentre outros $)^{250}$, que se vale do termo, mas, conforme expõe Howell A. Lloyd, os séculos XV e XVI não apresentam um uso corrente da palavra constitucionalismo. ${ }^{251}$

Os usos da palavra constituição em períodos anteriores ao século XVI, segundo McIlwain, em regra eram usos distintos dos de hoje, como o de governos limitados por leis e mecanismos institucionais de controle sobretudo parlamentares e judiciais dos governantes que, conforme visto, os comentadores acima citados empregam para os escritos calvinistas continentais do século XVI.

No Império Romano, segundo McIlwain, a palavra designava os atos legislativos exarados pelo imperador. Posteriormente, a Igreja toma de empréstimo o termo e designa com a mesma palavra "regulamentos eclesiásticos para a Igreja toda ou para uma província eclesiástica particular”. Durante a Idade Média tardia, por sua vez, afere-se a utilização do termo como "aplicável para os decretos seculares do período", possivelmente devido à Igreja ou aos livros de direito romano. ${ }^{252}$

McIlwain destaca uma série de juristas medievais, como Glanvill, que, na Inglaterra, utiliza a expressão como édito real, referente a decretos de Henrique II, Bracton, discorrendo sobre o Estatuto de Merton de 1236, chama uma de suas provisões "nova constituição", assim como designa uma seção de uma reedição da Magna Carta em 1225

\footnotetext{
${ }^{249}$ HÖPFL, Harro. Fundamental Law and the Constitution in Sixteenth-Century France. In: Die Rolle der Juristen bei der Entstehub. 1986, p. 338-339.

${ }^{250}$ BENERT, Richard Roy. Inferior Magistrates in Sixteenth-Century Political and Legal Thought. Tese Inédita. University of Minnesota. 1967; FRANKLIN, Julian H. Constitucionalism and resistance in the sixteenth century: the protestant monarchomachs. In: SPITZ, David. Political Theory and Social Change. New York: Atherton, 1967, p. 117; KINGDON, R. Calvinism and resistance theory, 1550-1580. In: BURNS, J. H.; GOLDIE, Mark. The Cambridge History of Political Thought, 1450-1700. Cambridge: Cambridge University Press, 2004, p. 193-218; SKINNER, Quentin. As fundações do pensamento político. São Paulo: Cia das Letras, 2000 ,

${ }^{251}$ LLOYD, Howell A. Constitucionalism. In: BURNS, J. H.; GOLDIE, Mark.The Cambridge History of Political Thought, 1450-1700. Cambridge: Cambridge University Press, 2004, p. 254.

${ }^{252}$ MCILWAIN, Charles Howard. Constitucionalism, ancient and moderm. New York: Cornell University Press, 1958. Ainda que Mcllwain referencie em termos de técnica legislativa a utilização do termo constituição como os atos emanados do Imperador, em Cícero na obra De Re Publica, o citado comentador vislumbra uma passagem que primeiro conteria a utilização da palavra numa acepção moderna, ao recomendar a forma de constituição mista para garantir a liberdade, no livro I dessa obra.
} 
como constitutio libertatis. Na França, Beaumanoir também chama atos do rei de une nouvele constitucion. Tais usos referem-se a decretos que se distinguem do costume. ${ }^{253}$

Porém, talvez a melhor explicação ou mesmo justificativa do uso da expressão constituição e principalmente seus derivados constitucionalismo ou constitucional para qualificar a resistência proposta pelos escritos huguenotes por tantos comentadores, seja de que há, de fato, nesses escritos uma inequívoca afirmação da necessidade de controles para os governos, que em muito se aproxima do uso contemporâneo que fazemos, cuja origem, é válido enfatizarmos, estaria em larga medida nos eventos políticos revolucionários de fundo calvinista como a Revolução Gloriosa e a Americana. Berman já utiliza a palavra constitucional para designar um dos atributos do Direito Urbano no período medieval que, conforme visto, constitui uma das bases para a resistência da cidade de Magdeburgo, que tanto inspirara Bèze, e reconhece a problemática do uso da palavra constitucional, nos seguintes termos: "Uma [...] característica principal do Direito Urbano fora seu caráter constitucional. A palavra constitucionalismo fora forjada no século XVIII e início do XIX para referir-se sobretudo à doutrina americana da supremacia da constituição escrita sobre as demais leis promulgadas. $" 254$

Um dos motivos que levam Berman a diagnosticar essa realidade constitucional consistiria no fato de tal forma de direito manifestar-se nas cidades medievais como: Cartas escritas consagradoras de seus direitos, assim como na organização dos governos e nos direitos civis e liberdades, e ainda, na estrutura das mesmas, posto que "os governos urbanos eram limitados em seus poderes, que geralmente se dividiam em poder executivo, legislativo e judiciário, que exerciam certos controles uns sobre os outros."255. Esses aspectos seriam perfeitamente apreciáveis, em termos genéricos, nos escritos monarcômacos de língua francesa, como os de Bèze, que por sua vez professam a necessidade da atuação dos soberanos se pautar no cumprimento de leis e juramentos, assim como de órgãos institucionalizados de controle dessa atuação.

Uma segunda questão preliminar seria delimitar a extensão da palavra secularização, que figura no subtítulo da presente dissertação.

\footnotetext{
${ }^{253}$ MCILWAIN, Charles Howard. Constitucionalism, ancient and moderm. New York: Cornell University Press, 1958.

${ }^{254}$ BERMAN, Harold J. Law and Revolution, The Formation of the Western Legal Tradition. v. I. Cambridge, Massachusetts \& London, England: Harvard University Press, 1983, p. 395-396.

${ }^{255}$ Ibidem, p. 396.
} 
É evidente que não seria nada razoável qualificar uma obra política do século XVI como destituída de um caráter confessional, ou de não extrair seus fundamentos últimos na seara teológica.

O próprio Bèze expõe os fundamentos teológicos últimos da vida civil em seu tratado, nos seguintes termos: “A verdadaira razão das organizações políticas bem ordenadas não é a tranquilidade dessa vida, como estimaram alguns Filósofos Pagãos, mas a glória de Deus, a qual toda vida presente deve objetivar."256

Isso posto, o que objetivamos com a palavra secularização é tão somente destacar a origem do principal argumento constitucional do tratado, que possui suas bases fundamentais nos estudos dos juristas da região de Hesse, de índole claramente secular, conforme foi anteriormente visto, principalmente tendo em vista, as raízes no direito feudal e nas leis fundamentais do Império Sacro-Germânico. Além de sinalizar a funcionalidade de tal expediente, no sentido de abrir, ao menos potencialmente, a perspectiva para a afirmação da universalidade do direito lícito de se resistir a governos tirânicos, em nada importando o quão distinta seja a circunstância geográfica ou histórica, restando assim inclusive aberta à facção calvinista a possibilidade de reconhecimento da validade dos argumentos, mesmo por opositores de outra crença.

Bèze assim reconhece seu esforço de secularização, ao comentar se haveria remédio contra um soberano que abusa de suas prerrogativas, dizendo que existem por certo tais remédios, "mesmo tendo recurso aos meios humanos"257, e para isso, nosso autor em larga medida se despoja de sua condição de teólogo expoente do calvinismo e recorre a todo o arcabouço humanístico, justificando o direcionamento de sua escrita: "Em suma, se quisermos procurar as histórias antigas registradas pelos [autores] profanos mesmo, encontra-se ser verdadeiro que a própria natureza parece nos dizer em alta voz [...]"258 que os governos são estabelecidos condicionalmente e constitui verdadeiro dever dos legítimos governantes perservar os justos e condenar os maus, sob pena de, se assim não fizerem, reverterem toda a ordem e merecerem inclusive a destituição dos cargos em que estão investidos ${ }^{259}$.

\footnotetext{
${ }^{256}$ BÈZE, Théodore de. Du Droit des Magistrats. Genève: Droz, 1970, p. 64.

${ }^{257}$ Ibidem, p. 8.

${ }^{258}$ Ibidem, p. 10.

259 Nesse sentido (quanto aos aspectos seculares da argumentação utilizada por Bèze), Christoph Strohm, ao analisar a versão latina do tratado, que conforme visto não apresenta nenhuma diferença substancial da versão francesa, alega que, ainda que o tratado inicie com a afirmação que somente caiba a Deus a máxima autoridade e a incondicional obediência, a questão sobre o que deve ser feito se advir um soberano que infrinja à lei de Deus e às leis humanas, "é respondida porém, essencialmente através da interpretação de textos do direito romano e medieval, assim como através do olhar sobre o exemplo de numerosos modelos de constituição na história. A tese decisiva do escrito, a saber, se, no caso de não cumpridos os estatutos do Reino, os magistrados inferiores
} 


\subsection{A supremacia do dever de obediência a Deus e não aos homens: a reafirmação das teses dos luteranos de segunda geração}

Bèze inicia seu tratado, num tom puramente teológico, desprestigiando, em suas primeiras páginas, referências à tradição clássica e afirma categoricamente que a única vontade a que os homens estão atrelados a obedecer incondicionalmente é a de Deus. Tal afirmação encontra resguardo na palavra de Deus, sendo o excerto bíblico que melhor autoriza Bèze a dar ênfase a tal afirmação, e mais extensamente referido e comentado por nosso autor em seu primeiro capítulo, é o capítulo 5 do Livro dos Atos dos Apóstolos, sobretudo em seu versículo $29^{260}$, em que depois, de nos versículos anteriores serem descritas as desavenças dos apóstolos e as autoridades judaicas do Templo, narra-se: "Pedro e os apóstolos porém, responderam: 'É preciso obedecer antes a Deus do que aos homens. ${ }^{, 261}$

A passagem acima referida, somada a outros exemplos bíblicos citados por nosso autor - como a recusa das parteiras a colaborarem com as ordens do Faraó de assassinar os recém-nascidos do sexo masculino, conforme narrado no Êxodo, que permite a salvação de Moisés, ou ainda a citação do não cumprimento, por parte dos companheiros do profeta Daniel, do édito que exigia a adoração da estátua de ouro feita por Nabucodonosor -, mostram-se como exemplos capazes de contrabalancear a problemática passagem de Romanos 13, já anteriormente analisada, que tanto atormentava a consciência dos reformadores e seu zelo pastoral.

Atualizando os exemplos de desobediências lícitas, diretamente ordenadas por Deus, para o seu conturbado tempo de guerras religiosas, Bèze exorta os fieis a desobedecerem às exigências dos magistrados civis indevidamente influenciados pelo papa e, por conseguinte, a não se obrigarem a participar de cerimônias religiosas católicas, o que insere a discussão na crítica recorrente, feita pelos reformadores das interferências da Igreja no mundo civil, pois conforme explica: "Assim hoje vemos tantos magistrados enfeitiçados pelo Anticristo Romano ordenarem seus súditos a se encontrarem no execrável serviço da missa, o dever de todos os fieis é não somente de não os obedecer nisso, mas também, a

são obrigados a resistir contra o soberano transformado em tirano, Bèza a explica preponderantemente com a ajuda de argumentos jurídicos." STROHM, Cristoph. Repercussões da formação jurídica na obra teológica de Bèze (tradução inédita de Danilo Chiovatto Serpa, no original: Wirkungen der Juristischen Schulung auf Bezas Theologisches (Euvre). In: BACKUS, Irena. Théodore de Bèze (1519-1605): Actes du Colloque de Genève (septembre 2005), Travaux d'Humanisme et Renaissance, CDXXIV. Genève: Droz, 2007, p. 528.

${ }^{260}$ KINGDON, Robert M. Nota 9. In: BÈZE, Théodore de. Du Droit des Magistrats. Genève: Droz, 1970 , p. 4.

${ }^{261}$ Atos dos Apóstolos 5, 29. In: Bíblia de Jerusalém. São Paulo: Paulus, 2006, p. 1910. 
exemplo de Elias e Eliseu e de toda antiga, verdadeira e pura Igreja, de se agregar nas santas assembleias para ouvir a palavra de Deus e participar dos Sacramentos, como o Senhor ordenou que seja feito em sua Igreja."262

Para Isabelle Bouvignes, em última análise, entende T. de Bèze que os limites para o poder do governante mais alto seriam as duas Tábuas da Lei descritas como instituídas ainda no Antigo Testamento, de tal modo que é um dever de todos os súditos não obedecer ao príncipe que desobedeça "ele mesmo aos mandamentos bíblicos", sejam os referentes aos deveres do povo em relação a Deus, ou os que disciplinam a relação entre os homens. Em termos concretos, a irreligiosidade de um soberano se manifestaria quando ele "compelisse seus súditos à idolatria, os impedir de adorar o Deus único, de respeitar seu nome e o sabbat [...]", ou seja, os comandos instituídos na primeira tábua; a iniquidade do mesmo governante seguiria, ao se constatar que o mesmo incita os súditos a desobedecer às obrigações propriamente humanas, estabelecidas na segunda tábua, como as de não adulterar, roubar, desonrar os pais. ${ }^{263}$

\subsection{O duplo pacto em Théodore de Bèze: uma aliança entre Deus com o Príncipe e seu povo e um contrato entre o Príncipe e o povo}

O sucessor de Calvino na Companhia de Pastores em Genebra vale-se da teoria contratual para reverter a eventual atribuição de sedição ao povo e a redireciona ao soberano tirano, pois quando o povo se vale de meios institucionais, pautando-se em condições previamente acordadas entre ele e o soberano, ocorre que a verdadeira sedição deve recair sobre os ombros do governante desvirtuado, "pois é uma regra geral que quando alguma condição é posta ou tacitamente compreendida em alguma convenção, a rompe quem contravenha a condição, e não aquele o qual só estando obrigado condicionalmente, é desobrigado, não por si mesmo (pois seria perjúrio) mas por aquele que rompeu o vínculo da obrigação, a saber a condição"264; dessa forma, "quando portanto um soberano se torna

\footnotetext{
${ }^{262}$ BÈZE, Théodore de. Du Droit des Magistrats. Genève: Droz, 1970, p. 6.

263 BOUVIGNIES, Isabelle. Monarchomachie: tyrannicide ou droit de résistance?. In: PIQUÉ, Nicolas; WATERLOT, Ghislain. Tolérance e Réforme: elements pour une généalogie du concept de tolérance. Paris: L' Harmattan, 1999, p. 87.

${ }^{264}$ BÈZE, Théodore de. Du Droit des Magistrats. Genève: Droz, 1970, p. 57.
} 
Tirano, e os povos fazem uso de seu direito contra ele, é ele quem por seu perjúrio desvinculou o povo, e não o contrário."265

Devido ao caráter sinalagmático da obrigação entre o soberano e o povo, tanto no que tange a sua formação como aos efeitos dela gerados, o acordo descrito por Bèze, poderia ser classificado perfeitamente como um contrato bilateral, ou seja, um contrato em que nenhuma das partes pode, "antes de cumprir sua obrigação, exigir a do outro"266 e, como consequência dessa dinâmica obrigacional, justamente uma das características dessa espécie contratual é o príncipio da exceptio non adimpleti contractus, que se originara de intérpretes do direito romano ${ }^{267}$, consistente na defesa ou "exceção de contrato não cumprido". Em outras palavras, a parte que previamente sofre o descumprimento do contrato por parte de outra, fica isenta de continuar adstrita ao vículo obrigacional que, no caso descrito por Bèze, seria justamente o povo que se coloca na posição de credor do soberano quanto às condutas lícitas opostas à tirania.

Além do mais, para Bèze, no bojo do contrato entre o povo e o príncipe, conforme mostraremos quando tratarmos das reações possíveis quando advier uma tirania manifesta, haveria um conjunto de condições vinculantes entre o soberano singularmente considerado e as magistraturas do Reino (sejam os Estados Gerais ou as magistraturas inferiores das cidades e vilas), que poderíamos chamar de um contrato subsidiário desse contrato principal entre o povo e o soberano, com a estipulação de um dever de mútua fiscalização, que se prestaria em última instância como garantia do contrato entre o povo e seu soberano.

Quanto aos compromissos assumidos entre Deus, em um pólo da relação e de outro lado o povo e seu soberano, conforme lemos, no exemplo da ordenação política de Israel que "Havia um juramento solene, pelo qual o Rei e o Povo se obrigavam a Deus, a saber, à observação das suas leis, tanto eclesiásticas quanto políticas e depois um outro

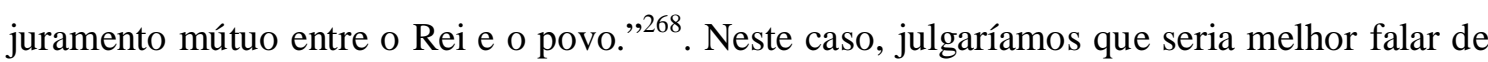
uma aliança ou uma relação de caráter institucional e não contratual, apesar de vários comentadores dizerem haver um duplo contrato ${ }^{269}$, uma vez que o pacto de Deus com os

\footnotetext{
${ }^{265}$ BÈZZ, Théodore de. Du Droit des Magistrats. Genève: Droz, 1970, p. 57.

${ }^{266}$ GOMES, Orlando. Contratos. Rio de Janeiro: Forense, 1996, p. 91.

${ }^{267}$ ALVES, José Carlos Moreira. Direito Romano. v. II. Rio de Janeiro: Forense, 1998, p. 115.

${ }^{268}$ BÈZE, Théodore de. Op. cit., p. 30-31.

${ }^{269}$ Apenas a título de exemplo, citamos Skinner e Souza. SKINNER, Quentin. As fundações do pensamento político. São Paulo: Cia das Letras, 2000, p. 510; SOUZA, Christine Alves de. L' apport de Théodore de Bèze a la Théorie Du Droit de Résistance dans le Traité Du Droit des Magistrats. In: Jacques Godefroy (1587-1652) et l' humanisme juridique à Genève, p. 202.
} 
homens no tratado de Bèze faria parte da dinâmica maior da aliança descrita na Bíblia entre Deus e os homens, que sempre se renova tanto no Antigo como no Novo Testamento.

Para J. Sacks, o contrato só pode ser mantido quando se extingue o interesse de um ou de ambos os pólos da relação por uma força externa e de maneira coativa (no caso do tratado de Bèze, quando o governante deixa de cumprir o estabelecido, seriam os órgãos institucionais Estados Gerais ou magistraturas inferiores das cidades e vilas que configurariam esse elemento externo e coator); já a aliança se manteria por um sentimento internalizado $^{270}$.

Como forma de melhor explicar a dificuldade de entender a relação entre os homens e Deus como um contrato, valemo-nos da mais recorrente das metáforas bíblicas dessa aliança, que seria o casamento entre o homem e a mulher, que suscitou por anos a fio uma discussão entre os estudiosos do direito civil, sobre a natureza jurídica do casamento no Ocidente, pois de um lado havia a tradição romana (e também adotada pelos canonistas) de o casamento ser um contrato, e do outro a tradição da civilização judaico-cristã, que percebia esse ato da vida civil como uma instituição ${ }^{271}$.

\footnotetext{
${ }^{270}$ SACKS, J. Rebuilding Civil Society: A Biblical Perspective. In: The Responsive Community 7/1 (1196/1997) p. 11-20, apud CORTINA, Adela. Aliança e Contrato. Política, Ética e Religião. São Paulo: Edições Loyola, 2008, p. 19.

${ }^{271} \mathrm{O}$ próprio Th. de Bèze, ao longo do tratado, faz uma série de comparações da relação entre o soberano e o povo com contratos de várias espécies, como o contrato comum entre particulares, o contrato feudal, com o intuito de demonstrar a perfeita possibilidade de uma das partes deixar de cumprir o contrato, quando a outra deixa de adimplir aquilo que deve fazer. Nessa enumeração de espécies de contrato, um seria mais diferenciado que os demais, o contrato do casamento, conforme lemos em: "De resto, há alguma obrigação mais estreita entre os homens, que aquela do casamento, na qual Deus, ele mesmo intervém, como principal autor do contrato, e pelo qual duas pessoas são feitas uma carne? E contudo pelo dizer do apóstolo [Paulo em Coríntios 7:5], se uma das partes abandona a outra completamente, aquela que é abandonada fica livre de sua obrigação, ainda mais que a outra violou a condição principal posta no casamento.” (BÈZE, Théodore de. Du Droit des Magistrats. Genève: Droz, 1970, p. 51). Como se vê, tão somente por Bèze o compreender como um contrato, ele pode ser desfeito, mas é importante o registro que nosso autor ainda que o chame de contrato (até por falta de outro paradigma jurídico em seu horizonte mental, já que no século XVI imperava a noção do casamento como contrato em larga medida pela autoridade dos canonistas que assim o compreendiam), em Du Droit des Magistrats, Bèze o descreve de forma extremamente peculiar, principalmente pelo grau de aproximação que exige das partes (a conjunção carnal), e o fato de ter sido o próprio Deus autor desse contrato, talvez num esforço de contestação à noção simplória do casamento como um contrato, numa atitude que a nosso ver aproximaria Bèze daquilo que seria a corrente institucionalista do casamento, desenvolvida amplamente apenas no século
} XIX.

Segundo Christoph Strohm, Théodore de Bèze teria escrito em 1568 De Polugamia et divortiis e em 1569 De Repudis et Divortiis, cuja temática central era a questão da poligamia e do divórcio, tais obras têm como origem um escrito de Bernardino Ochino publicado em 1563, no qual se defende que no Velho Testamento a poligamia não era fundamentalmente proibida segundo a lei de Moisés, e consequentemente o casamento monogâmico seria uma instituição meramente humana e mutável.

Devido ao teor pouco ortodoxo das teses de Ochino, Bèze temia que as mesmas pudessem municiar as acusações contra os reformados em geral, como também nosso autor viu-se obrigado diante das circunstâncias a esclarecer as questões, dando ênfase na unidade do Antigo e do Novo Testamento, além do dever de compatibilizar em sua exegese a alta estima que se deve ter com a lei do Antigo Testamento e com as declarações contidas no Novo, como também se sente no dever de trazer ao debate da questão noções do direito romano canônico (ainda que o faça com certo constrangimento, mas se justifica alegando a necessidade de se 
Tanto o Novo como o Antigo Testamento adotam de forma recorrente tal metáfora; a título de exemplo, no livro de Oséias, o profeta lamenta a relação de Israel com Deus, sendo o primeiro comparado à esposa infiel, e o signo da infidelidade dessa esposa se dá principalmente pelo pecado da idolatria ${ }^{272}$; assim Deus revela ao profeta sua relação com o seu povo: "Disse-me Iahweh: 'Vai novamente, ama uma mulher amada por outro e que comete adultério, como Iahweh ama os israelitas, embora estes se voltem para os deuses estrangeiros $[\ldots]^{,, 273}$.

No Novo Testamento tal metáfora persevera como símbolo da relação entre Deus e os homens, sobretudo com a transposição dos benefícios e encargos do povo eleito que deixa de ser Israel e passa a ser qualquer homem agredado pela Igreja. Assim Paulo descreve tal relação em sua exortação à comunidade de Éfeso:

E vós, maridos, amai vossas mulheres, como Cristo amou a Igreja e se entregou por ela, a fim de purificá-la com o banho da água e santificá-la pela Palavra, para apresentar a si mesmo a Igreja, gloriosa, sem mancha, nem ruga, ou coisa semelhante, mas santa e irreprensível. Assim também os maridos devem amar suas próprias mulheres, como a seus próprios corpos. Quem ama sua mulher ama-se a si mesmo, pois ninguém jamais quis mal à sua própria carne, antes alimenta-a e dela cuida, como também faz Cristo com a Igreja, porque somos membros do seu Corpo. Por isso deixará o homem seu pai e sua mãe e se ligará à sua mulher, e serão ambos uma só carne. É grande esse mistério: refiro-me à relação entre Cristo e sua Igreja. Em resumo, cada um de vós ame a sua mulher como a si mesmo e a mulher respeite o seu marido ${ }^{274}$

Conforme se depreende do texto de Paulo, vislumbra-se uma natureza internalizada, de comunhão e de perenidade da relação entre Deus e os homens, que por sua

trazê-la ao debate para equacionar os aspectos jurídicos do matrimônio). Especificamente na obra de 1569, Bèze "acentua a diferença do contrato de casamento com todos os demais celebrados entre os homens. Pois naquele, diferente destes, segundo Mt 19:6, Deus é autor, e consequentemente, limitada é a competência das autoridades seculares." Strohm, Cristoph. "Repercussões da formação jurídica na obra teológica de Bèze" (tradução inédita de Danilo Chiovatto Serpa, no original: Wirkungen der Juristischen Schulung auf Bezas Theologisches (Euvre). In: BACKUS, Irena. Théodore de Bèze (1519-1605): Actes du Colloque de Genève (septembre 2005), Travaux d Humanisme et Renaissance, CDXXIV. Genève: Droz, 2007, p. 526-527.

${ }^{272}$ Os 2: 4-25. In: Bíblia de Jerusalém. São Paulo: Paulus, 2006, p. 1585-1588.

${ }^{273}$ Os 3 : 1-4. In: Bíblia de Jerusalém. São Paulo: Paulus, 2006, p. 1588.

${ }^{274}$ Ef 5 : 25-33. In: Bíblia de Jerusalém. São Paulo: Paulus, 2006, p. 2046. 
vez é análoga ao casamento nos termos bíblicos, e este último por sua vez, para muitos, não poderia ser tratado como um contrato.

Nesse mesmo sentido, cumpre-nos o registro da interpretação de Guillermo Borda, no bojo dessa discussão sobre a natureza jurídica do casamento, que repele a hipótese de que ele seja considerado um contrato, mas sim uma instituição ${ }^{275}$, pois:

a) o contrato é uma especulação (o vendedor procura o preço mais alto e o comprador, o preço mais baixo); a instituição é um consortium, onde os interesses são coincidentes; b) o contrato rege-se pela igualdade; a instituição, pela disciplina; c) o contrato é uma mera relação exterior aos contratantes, é um laço obrigacional; a instituição, uma interiorização; e) o contrato representa uma trégua na batalha dos direitos individuais, sendo produto da concorrência; a instituição, um corpo cujo destino é ser compartilhado por seus membros, portanto produto da comunicação; f) o contrato é precário, desata-se como foi formado, extinguindo-se com o pagamento; a instituição é feita para durar; g) o contrato é uma relação subjetiva de pessoa a pessoa; as relações institucionais são objetivas e estatutárias $^{276}$

A nosso ver, o povo e seu soberano aderem à aliança com Deus da forma tal qual é imposta por este último, sem condições de adotar regras distintas, ingressando de forma análoga, como faz um nubente, segundo a corrente institucionalista, adentra num "estatuto imperativo preorganizado" 277 ao se casar.

Quanto à possibilidade de se aventar a hipótese de se tratar de um contrato unilateral, somos um tanto quanto refratários a aceitar tal juízo sobre os compromissos de Deus para com o povo e seu governante, pois: "no momento em que se forma [o contrato unilateral], origina obrigação, tão somente, para uma das partes - ex uno latere. A outra parte não se obriga. O peso do contrato é todo de um lado, os efeitos são somente passivos de um

\footnotetext{
${ }^{275}$ Para os adeptos dessa corrente, a natureza jurídica do casamento como instituição se deve pelo fato de que o estado matrimonial "se define num estatuto imperativo e preorganizado, ao qual aderem os que casam. $\mathrm{O}$ ato de adesão, embora voluntário, não se confunde com o contrato, pois é a aceitação inevitável de um estatuto tal como se apresenta, sem liberdade para adotar regras diversas." GOMES, Orlando. Direito de Família. Rio de Janeiro: Forense, 1994, p. 51.

${ }^{276}$ BORDA, Guillermo. Tratado de derecho civil. v.1. Buenos Aires: Abeledo-Perrot, 1969, p. 53 apud DINIZ, Maria Helena. Curso de Direito Civil. São Paulo: Saraiva, 1998, p. 38.

${ }^{277}$ GOMES, Orlando. Direito de Família. Rio de Janeiro: Forense, 1994, p. 51.
} 
lado, e somente ativos de outro." 278 Realidade que não nos parece coadunar com as narrativas judaico-cristãs que impõem fardos pesados a Deus, como o envio de leis, profetas, guerreiros, e mesmo o fenômeno da encarnação e o padecimento de morte em cruz, apontando para um cumprimento de efeitos de tal aliança, disciplinadamente executados por Deus em benefício dos homens.

Além do mais, é preciso registrar dois problemas ao considerar-se um contrato a relação formada pelo pacto entre Deus e os homens: 1) a inexistência de uma instância idônea para julgar o próprio Deus, caso, ele se torne inadimplente; 2) a impossibilidade de Deus ser faltoso com quaisquer de suas promessas.

O contrato, na concepção de Bèze, tem uma natureza instrumental, com o escopo de por a salvo os governados da opressão perpetrada pelos governantes e elege como instância decisória para dirimir os problemas decorrentes da quebra desse contrato, em primeiro lugar, os Estados-Gerais e, na leniência dos mesmos, ativaría-se um freio subsidiário, os magistrados inferiores das cidades e vilas, aptos a pelo menos anularem os atos dos tiranos que recaíam sobre os que estão sob o seu encargo, assim como aliarem-se às partes sãs dos Estados $^{279}$. Ou seja, Bèze expõe sua teoria política em uma linguagem contratual, assim como assinala, algo inerente a ela, uma instância apta a julgar tal contrato.

Além do mais, as construções da noção de contrato experimentadas pelo direito romano ou no mundo medieval, fontes para o contratualismo de Bèze, previam uma instância capaz de dirimir conflitos advindos de eventual problema entre as partes envolvidas; no direito romano, os contratos eram resolvidos por órgãos com funções jurisdicionais ${ }^{280}$, os pretores. No direito feudal, havia a previsão de uma corte, e mesmo de um recurso dessa decisão a uma outra corte hierarquicamente superior, caso a decisão fosse desfavorável ao vassalo. $^{281}$

Não nos parece possível a instituição de um juízo, tribunal, pretor ou assembleia com aptidão para julgar os feitos, principalmente de Deus, que devem ser pautados pela aliança, e em certa medida, dos homens, nessa peculiar relação de aliança.

A nosso ver, segundo os escritos de Bèze relativos a essa relação, as questões conflitivas restam solucionadas pela auto-tutela das partes, tendo em vista não haver uma

\footnotetext{
${ }^{278}$ GOMES, Orlando. Contratos. Rio de Janeiro: Forense, 1996, p. 71.

${ }^{279}$ BÈZE, Théodore de. Du Droit des Magistrats. Genève: Droz, 1970, p. 53.

${ }^{280}$ PEREIRA, Caio Mário da Silva. Instituições de Direito Civil: Contratos. v. III. Rio de Janeiro: Forense, 1981, p. 12.

281 BERMAN, Harold J. Law and Revolution, The Formation of the Western Legal Tradition. v. I. Cambridge, Massachusetts \& London, England: Harvard University Press, 1983, p. 307-310.
} 
instância capaz de dirimi-las, ou seja, trata-se de Deus, punindo seu povo de várias formas, mas sobretudo mediante a possibilidade de permitir o advento da tirania, tese geral recorrente em vários reformadores magisteriais que Bèze assim descreve: "Eu admito que as orações conjugadas com o arrependimento são os remédios próprios e necessários para afastar a tirania pois quando é um mal ou flagelo enviado por Deus e muito frequentemente para castigar os povos" 282 , e evidentemente isso em nada incompatibilizaria outros remédios humanos para combater a tirania.

Ou ainda o próprio povo pode, conforme o relato bíblico do Livro do Êxodo, recolher suas joias de ouro e plastificar um Deus na forma de bezerro, adulterando a aliança com Deus, após exigirem soluções de Aarão no desalento do deserto, com a tardança de Moisés $^{283}$

A segunda razão para não se adotar a noção de contrato, na relação entre o povo e seu Deus, consiste no fato de Bèze expor de forma indireta a inutilidade de um contrato para dirimir conflitos no exemplo de que, enquanto Israel tivera como monarca o próprio Deus, em hipótese nenhuma, ele poderia comandar de forma tirânica. Esses mecanismos de freios dos governantes, intrínsecos à via contratual, apenas foram instituídos naquela particularíssima organização política da Antiguidade tão somente após o despojamento dessa dádiva por seu próprio povo.

\subsection{Constitucionalismo, História e Secularização no debate sobre a vida civil em Bèze no problema crucial do tratado: a Tirania Manifesta}

A sexta questão do tratado de Théodore de Bèze, "Qual é o dever dos súditos em relação ao soberano legítimo tendo se tornado um tirano manifesto", além de quantitativamente ser a mais extensa, em termos qualitativos se mostra a parte mais importante de toda obra, uma vez que responde a mais problemática das questões que o nosso autor diz enfrentar em sua época, a da tirania manifesta, e apresenta a peculiaridade de um afastamento da exclusividade da autoridade bíblica, para a inserção de exemplos seculares da história universal que chancelam uma reação ativa em face de uma tirania.

\footnotetext{
${ }^{282}$ BÈZE, Théodore de. Du Droit des Magistrats. Genève: Droz, 1970, p. 11.

283 Êxodo 32. In: Bíblia de Jerusalém. São Paulo: Paulus, 2006, p. 148.
} 
Tal distanciamento da autoridade bíblica faz-se necessária para uma fundamentação pautada numa ideologia que Quentin Skinner denomina de constitucionalismo $^{284}$, o que requer um amparo na fundamentação do discurso dessa ideologia no atributo da historicidade. Uma vez que conceitualmente o constitucionalismo está associado a ideia de "governos moderados, limitados em seus poderes" 285 , é certo que, por extensão conceitual, apresenta os atributos de universalidade e historicidade, que geralmente são reconhecidos nos direitos fundamentais de primeira geração ${ }^{286}$, coincidentemente tidos como marcos inaugurais ao constitucionalismo do Ocidente ${ }^{287}$.

Esse ponto da história do Direito Constitucional é identificado pelos historiadores deste ramo do Direito com os movimentos de fundo calvinista na Inglaterra do século XVII (Revolução Gloriosa) e nos Estados Unidos do XVIII (Independência norte-americana, além da Revolução Francesa), que consagram os direitos de livre consciência tanto política como religiosa e de propriedade (ao menos no plano formal), questões que já em larga medida são tratadas por calvinistas continentais no século XVI, como Bèze.

Skinner explica o recurso ao constitucionalismo como algo de extrema conveniência para parcela significativa da nobreza francesa, que já aderira à nova fé, pois tal teoria permitia um espaço de negociação, amplamente secular, com o partido católico moderado, uma vez exaurida a possibilidade de se discutir aspectos religiosos potencialmente intervenientes na vida política, além de permitir um distanciamento da identificação dos tratados monarcômacos, como o de Bèze, com o caráter de radicalidade, que os autores tentavam evitar a todo custo:

Embora o principal objetivo desses tratados fosse - inquestionavelmente justificar um ataque direto à monarquia Valois, é importante acrescentar que, mesmo depois dos massacres de 1572, os huguenotes ainda se preocupavam em repudiar o mais possível quaisquer elementos populistas ou insurrecionais presentes no legado do pensamento calvinista. Embora seu interesse maior fosse o de exortar seus correligionários a tomar em armas, precisavam também ampliar sua base de apoio entre os não-protestantes e

\footnotetext{
${ }^{284}$ SKINNER, Quentin. As fundações do pensamento político. São Paulo: Cia das Letras, 2000, capítulo 16.

${ }^{285}$ FERREIRA FILHO, Manoel Gonçalves. Curso de Direito Constitucional. São Paulo: Saraiva, 1993, p. 7. Importa registrarmos que até o século XVII, "governo constitucional" significava governo de acordo com a antiga constituição (lei fundamental) seja ela qual for, inclusive podendo ser perfeitamente uma monarquia absoluta.

${ }^{286}$ BOBBIO, Norberto. A Era dos Direitos. Rio de Janeiro: Campus, 1992, p. 70-71.

${ }^{287}$ BONAVIDES, Paulo. Curso de Direito Constitucional. São Paulo: Malheiros, 2007, p. 563.
} 
minimizar tanto quanto possível a crescente hostilidade dos católicos moderados, cujas simpatias vinham perdendo a cada dia [...] em razão da contínua tendência à anarquia. Em decorrência dessas pressões conflitantes, embora os líderes huguenotes agora desejassem instilar em seus seguidores a ideia do direito à resistência ativa, continuam, ao mesmo tempo, a salientar na medida do possível o caráter limitado constitucional e essencialmente defensivo de seu apelo às armas.

Cuidaram, antes de mais nada, de excluir toda ideia de resistência por parte de indivíduos ou mesmo de todo o conjunto do povo ${ }^{288}$ [conferindo, em regra, tão somente aos magistrados e não ao povo desnudado de sua representação, o direito e o dever de combater os tiranos].

Quanto à questão do recurso à história, no bojo de sua fundamentação constitucionalista, Bèze a desenvolve em seu tratado de modo muito semelhante a uma de suas fontes da historiografia clássica: Tito Lívio, que na obra Ab Urbe Condita Libri, a mais citada pelo reformador genebrino, assim diz sobre a função moralizante que a História pode ter para uma nação:

[...] a meu ver, o que é preciso estudar com toda a atenção é a vida e os costumes de outrora, é a obra dos homens que na paz e na guerra ajudaram a construir e engrandecer o império. Em seguida, observar como o paulatino enfraquecimento da disciplina acarretou, por assim dizer, o relaxamento dos costumes e como sua decadência cada vez mais acentuada levou-os à queda brusca de nossos dias, quando a corrupção tanto quanto seus remédios nos parecem insuportáveis.

O que é sobremodo salutar e producente, no conhecimento da história, são os exemplos instrutivos de toda espécie que se descobrem à luz da obra [Ab Urbe Condita Libri]. Nela se encontraram, para o teu benefício e o de teu país, modelos dignos de imitação assim como ações vergonhosas, cujas causas e consequências é preciso evitar." 289 Ou seja Tito Lívio "atribui a seus personagens de eleição aquela soma de virtudes que convencionalmente associamos ao romano antigo. É sua convicção de que semelhantes virtudes

\footnotetext{
${ }^{288}$ SKINNER, Quentin. As fundações do pensamento político. São Paulo: Cia das Letras, 2000, p. 576.

${ }^{289}$ LÍVIO, Tito. História de Roma (Ab Urbe Condita Libri). São Paulo: Paumape, 1989, p. 18.
} 
não mais tinham lugar em meio à corrupção geral de sua época, propensa ao luxo, à moleza, à sensualidade. ${ }^{290}$

Em certo sentido, Bèze, ao apontar a degeneração que a tirania traz para o sistema político de sua época, na França dos Valois, imersa nos conflitos religiosos, e os remédios contrários a tal tirania, tenta eleger modelos de liberdade e boa condução da política como havia feito na Antiguidade Clássica, Tito Lívio.

O sucessor de Calvino na Companhia de Pastores em Genebra, após apresentar em tese os mecanismos institucionais para frear os tiranos, e antes de adentrar num amplo rol de exemplos históricos, distribuídos num vasto espectro geográfico e cronológico, assim justifica sua proposta moralizante semelhante a de Tito Lívio, sendo categórico: "E de fato vejamos se em todos os tempos e em todas as nações mais conhecidas, se isso não foi assim praticado." 291

Um ponto importante no manejo da historiografia como autoridade de fundamentação do tratado é a peculiar ocorrência, nesse capítulo, de um recuo do uso autoridade da história bíblica e, portanto, de afinidade teológica, para uma historiografia sobretudo da tradição clássica. Mesmo quando citada a história de Israel, Bèze, nesse tópico de seu tratado, maneja a mesma de forma peculiarmente secular, conforme veremos.

Outra característica da alocação dos exemplos históricos é a sua disposição em ordem não cronológica, mas de importância, para elaborar uma teoria substancialmente convincente, a fim de que protestantes de seu tempo possam resistir em boa consciência na França de sua época contra a tirania dos Valois, a exemplo de dispor o paradigma da Roma

\footnotetext{
${ }^{290}$ PEIXOTO, Paulo Matos. Introdução. In: LÍVIO, Tito. História de Roma (Ab Urbe Condita Libri). São Paulo: Paumape, 1989, p. 13.

${ }^{291}$ BÈZE, Théodore de. Du Droit des Magistrats. Genève: Droz, 1970, p. 24. Apesar de Bèze, como os demais autores políticos calvinistas do século XVI oporem-se, de forma direta ou indireta, às ideias de Maquiavel, principalmente sobre a instituição do principado, no que tange ao recurso à história para seu corpo argumentativo e suas repercussões na política, um paralelo quanto à justificativa de tal expediente apresenta-se perfeitamente viável entre o florentino e os protestantes, pois conforme explica Patrícia Fontoura Aranovich, ao discorrer sobre as relações entre história e política na obra de Maquiavel: "A razão por si só não tem clareza suficiente para sustentar uma posição, e apenas quando amparada pelos exemplos assume a capacidade de ser um fundamento seguro para o conhecimento. Neste sentido, a imaginação, compreendida como a razão sem o apoio da história, não pode cumprir este papel. Maquiavel desqualifica aqui, o que poderíamos chamar de pensamento abstrato da política ou, ainda, de ideal, assimilando-o a imaginação ou fantasia. O que guia esta perspectiva é a ideia de que, em Maquiavel, política e história não podem ser separadas, porque se o forem, serão insuficientes para a compreensão da realidade. Ou seja, a história é a única realidade e qualquer pensamento político deve ser nela fundada, sob pena de se tornar fantasmagórico. [...] Maquiavel afirma no capítulo 15 de O Príncipe, [...] que não falará de repúblicas que jamais existiram, mas das que existiram e existem de fato e, já no primeiro capítulo do Príncipe, Maquiavel havia colocado a questão, senão nestes termos precisos, de um modo bastante claro, ao afirmar que seu objeto são os estados que existem e existiram, os estados reais". ARANOVICH, Patrícia Fontoura. História e Política em Maquiavel. São Paulo: Discurso Editorial, 2007, p. 27-29.
} 
antiga inicialmente e não o da Grécia Antiga, pois segundo nosso autor, o primeiro conteria os fundamentos da monarquia francesa. Por fim, arremata circularmente a exemplificação, justapondo, ao fim dos exemplos, a sua concepção de uma monarquia francesa condicionada.

O uso não-cronológico dos exemplos históricos, conforme explica Paul-Alexis Mellet, seria justificado na medida em que:

Em o Direito dos Magistrados, Bèze indica que a mesma 'regra de retidão' guia tanto os Cristãos como os Pagãos. No decorrer da longa lista de 13 exemplos ilustrando o poder dos magistrados, de resto ele aborda sucessivamente: os Romanos, os Atenienses, os Lacedemônios, a monarquia de Israel, antes de passar a exemplos mais recentes. A distinção que fiz até aqui, entre os exemplos bíblicos e históricos, constitui assim um verdadeiro anacronismo. A lei de Deus inspirou, mesmo sem ter essa intenção, todos os homens. A partir disso, os exemplos podem ser tirados indistintamente da história bíblica, antiga, medieval ou mesmo moderna. ${ }^{292}$

O que sugere em última análise que o recurso à história está associado à ideia de universalidade que Bèze pretende atribuir às suas teses de resistência.

Quanto aos exemplos de sua época ou bem próximos a ela, Bèze expõe um caráter que é próprio do calvinismo, para o qual ele mesmo contribui, que seria o elemento de internacionalismo desse ramo da fé reformada, uma vez que:

Os protestantes calvinistas tinham um credo e uma causa que ultrapassava as fronteiras e que se manifestava não apenas por meio de suas simpatias políticas mas também pelos bolsos e bolsas. Os calvinistas ingleses intervieram militarmente na Escócia, na primeira Guerra de Religiosa na França e nos Países Baixos. Acolheram com satisfação e ajudaram a sustentar igrejas de "estrangeiros" franceses e holandeses em Londres e em outros lugares. Levantaram recursos para a defesa de Genebra contra o duque de Savóia na década de 1580 e para ajudar ao Palatinado, devastado pela Guerra dos Trinta Anos na década de 1620. Trata-se de uma história de soldados (voluntários ou mercenários) e de financistas. ${ }^{293}$

${ }^{292}$ MELLET, Paulo-Alexis. Du Passé au Présent: Les Sources du Droit des Magistrats sur leurs Sujets (1574). In: BACKUS, Irena Théodore de Bèze (1519-1605): Actes du Colloque de Genève (septembre 2005), Travaux d'Humanisme et Renaissance, CDXXIV. Genève: Droz, 2007, p. 541-542.

${ }^{293}$ COLLINSON, Patrick. A Reforma. Rio de Janeiro: Objetiva, 2006, p. 121. 
Como centro articulador dessa dimensão internacional do calvinismo, para não dizer do próprio Calvinismo em si, Patrick Collinson responsabiliza por tal proeza, sobretudo o próprio Bèze, fornecendo uma boa síntese do dinamismo intelectual e político de nosso autor, ao descrever a origem do Calvinismo da seguinte forma:

[o calvinismo] Como sistema de ideias e práticas, entretanto, foi principalmente criado pela geração seguinte, especialmente Théodore de Bèze (1519-1605), conhecido como Beza, primeiro professor da Academia de Genebra, onde deu aulas durante quase quarenta anos. Beza se tornou sucessor de Calvino como o mais graduado da Companhia dos Pastores e conselheiro de igrejas e governos civis de status internacional. Foi Beza quem durante todos aqueles anos poupou o Calvinismo das lutas intestinas que esfacelaram o Luteranismo após a morte de Lutero. [...] A ordem da Igreja calvinista passou a ser considerada universalmente normativa, até mesmo nos Estados monárquicos, e uma carta de Beza sobre o tema dos bispos ajudou o lançamento do Presbiterianismo na Inglaterra e na Escócia (embora até mesmo Beza soubesse usar de brandura ao escrever a Elizabeth da Inglaterra). As políticas calvinistas se enrijeceram e Beza sancionou, como jamais fizera Calvino, o direito dos 'magistrados inferiores' de resistir

a governantes tirânicos" ${ }^{294}$, [nas mais diversas circunstâncias históricas e geográficas, em que aparecesse o problema da tirania].

\subsection{As reações possíveis à Tirania Manifesta segundo as vocações dos particulares e dos graus de magistraturas}

Bèze inicia o sexto tópico de seu tratado alertando para a urgência, em sua época de perseguições por motivos reliogiosos da nova fé reformada, de saber o que os súditos podem fazer em em boa consciência, "quando seus Magistrados soberanos, outrora legítimos, tornam-se Tiranos totalmente manifestos".

\footnotetext{
${ }^{294}$ COLLINSON, Patrick. A Reforma. Rio de Janeiro: Objetiva, 2006, p.122.
} 
A questão é desdobrada por nosso autor em duas possibilidades: quando se deve suportar sem nenhuma resistência e quando é o caso de se chegar à luta armada. ${ }^{295}$

Bèze condiciona sua resposta à problemática suscitada pelo tipo da vocação de cada súdito em relação ao Príncipe, que em certa medida constituiria o grau de obediência ao soberano, salvo eventos extraordinários.

Essas vocações seriam de três tipos. Primeiramente, pessoas totalmente privadas, sem nenhum cargo do Estado, (no sentido tanto de obrigação encargo, como o de pertencer à administração estatal então nascente). Uma segunda espécie de súditos seriam magistrados subalternos e inferiores ao soberano ${ }^{296}$, e por fim, Bèze arrola uma terceira espécie de súditos, que também seria uma segunda de magistrados, que por vezes também são denominados de inferiores, porém "embora não detenham o poder soberano e ordinário para conduzir, entretanto existem para servir como rédea e freio ao soberano Magistrado."297

Quanto às pessoas privadas, Bèze discute sua atuação em duas circunstâncias, em que nada poderiam fazer: a primeira, havendo o advento de uma tirania de origem, mas que é sanada, por parte dos governados, através de um consentimento expresso e voluntário, que eliminaria a ilegitimidade da dominação injusta perpetrada pelo usurpador. Realidade que, na concepção de Bèze, ocorrera com o povo romano em relação a Augusto e seus sucessores ${ }^{298}$.

A mesma postura de obediência exorta Bèze às pessoas privadas (governados), na circunstância de ocorrer uma tirania manifesta, ou seja, o magistrado legítimo, aqui no sentido de governante, recebendo licitamente o poder, desvia-se para uma tirania, a exemplo do que ocorrera com Abimelec entre os israelitas, descrito no Livro dos Juízes, os Trinta de Atenas e o Decenvirato romano, e muitos outros exemplos afora.

Bèze responde que, para ambas as situações, não é lícito a nenhum particular se opor à força a tais governantes, salvo se ocorrer uma "extraordinária vocação divina" 299 para um determinado particular excepcionalmente reagir ao jugo injusto dessas tiranias.

Resta a essa categoria de súditos as opções de se retirarem para longe da jurisdição do tirano ou permanecer sob o seu jugo, com a ressalva de recorrerem a Deus, para não se fazerem ministro da tirania contra alguém e nada obter daquilo que é devido a Deus e

\footnotetext{
${ }^{295}$ BÈZE, Théodore de. Du Droit des Magistrats. Genève: Droz, 1970, p. 15.

${ }^{296}$ Enfrentaremos posteriormente, no capítulo conclusivo, a problemática do alcance do significado da expressão magistrado nos tempos de Bèze, desfazendo as aparentes ambiguidades que o tratado traz na utilização dessa palavra, que designa ora o centro da opressão da tirania, na figura do supremo magistrado e seus delegatários, e ora a palavra é alocada no pólo da resistência constitucional, manifestada pelos "magistrados que servem de rédea e freio ao soberano".

${ }^{297}$ BÈZE, Théodore de. Du Droit des Magistrats. Genève: Droz, 1970, p. 15-16.

${ }^{298}$ Ibidem, p. 16.

${ }^{299}$ Ibidem, p. 16.
} 
a seu próximo ${ }^{300}$, ou seja, Bèze exorta os súditos que vivem sob a jurisdição de um tirano, para que não se associem, ainda que involuntariamente, às vilanias do tirano.

O sucessor de Calvino em Genebra justifica tal exortação aos particulares da seguinte forma: "fazendo de outra forma, infinitas perturbações se seguiriam, piores que a Tirania mesma, sobrevindo mil novos Tiranos sob a sombra de se querer impedir um."301 Assim esclarece os contornos prudentes e limitados de sua proposta de resistência política, quando comparada à dos reformadores radicais.

Além desse argumento político, de natureza secular, apela à autoridade bíblica, que se destaca no conjunto do capítulo, pois é a primeira vez que Bèze lança mão dela, no mais laico de seus capítulos. Nosso autor, dentre os argumentos da palavra de Deus, inicia com a notória exortação de Paulo aos romanos (Rom 13, 1:7), discutida em escritos políticos de todos os reformadores do século XVI, sendo também a primeira das raras citações da passagem no tratado ${ }^{302}$. Outro exemplo de exortação bíblica implícita é a de Pedro em sua Primeira Epístola ${ }^{303}$. Bèze reforça a argumentação de Pedro, lembrando que nos Evangelhos este apóstolo havia sido repreendido pelo próprio Cristo, quando, como particular, desembainhou a espada contra o poder público, ainda que esse último estivesse cometendo abuso contra seu mestre. ${ }^{304}$ Postura de obediência também assinalada por Bèze no período histórico da Igreja Primitiva, em que a cristandade era cruelmente perseguida por Tibério e Nero, e continuaram sendo perseguidos, mesmo depois, por imperadores que governavam à época de éditos feitos para proteção dos cristãos, que eram deslealmente desrespeitados. ${ }^{305}$

Em termos conclusivos, Bèze arremata a questão da lícita postura de particulares diante uma tirania de origem (enfatiza-se, quando sanada pelo consentimento), ou de uma tirania manifesta, nos seguintes termos: "Em suma, portanto, minha resposta é, para essa questão, que não é lícito a nenhum particular resistir a força aos tiranos à dominação dos quais previamente o povo terá consentido; e que, sendo a questão um contrato feito entre duas pessoas privadas, deve-se respeitar a promessa até mesmo devendo-se suportar um prejuízo ao

\footnotetext{
${ }^{300}$ BÈZE, Théodore de. Du Droit des Magistrats. Genève: Droz, 1970, p. 16.

${ }^{301}$ Ibidem, p. 17.

${ }^{302}$ A outra citação ocorre no capítulo XVI do tratado de Bèze.

303،Sujeitai-vos a toda instituição humana por causa do Senhor, seja ao rei como soberano, seja aos governadores, como enviados seus para a punição dos malfeitores e para o louvor dos que fazem obem, pois esta é a vontade de Deus que, fazendo o bem, tapeis a boca à ignorância dos insensatos. Comportai-vos como homens livres, não usando a liberdade como cobertura para o mal, mas como servos de Deus. Honrai a todos, amai os irmãos, temei a Deus, tributai honra ao rei.”. Pedro 2, 2:17. In: Bíblia de Jerusalém. São Paulo: Paulus, 2006, p. 2115

${ }^{304}$ BÈZE, Théodore de. Du Droit des Magistrats. Genève: Droz, 1970, p. 17.

${ }^{305}$ Ibidem, p. 17.
} 
invés de desrespeitar o contrato, é muito mais ainda evidente o dever de um particular evitar de se safar de uma obrigação, contratada por um consentimento público.”306

Percebe-se que, no segundo caso, Bèze faz uma transposição da teoria contratual do Direito Privado para a esfera política, e no bojo dessa transposição, reafirma o princípio contratual do pacta sunt servanda. ${ }^{307}$

Paradoxalmente, tal princípio encontra sua origem entre os canonistas dos séculos XII e XIII, e teve sua inserção no sistema jurídico francês ainda em construção no século XII, pela via do Direito Costumeiro, de início, apenas na região de Beauvais, e depois espalhado por toda a França, pelos intendentes reais ${ }^{308}$. Ou seja, nosso reformador valeu-se em última análise da autoridade argumentativa de forças às quais ele se opunha categoricamente: os papistas e o processo de centralização política da França.

Os canonistas do século XII e XIII elaboraram o princípio do pacta sunt servanda a partir da disciplina penitencial, que consagrava o fato de toda promessa ser vinculante e, “em razão disso, não é uma defesa legítima em uma ação que verse sobre um contrato, alegar que ele não fora elaborado de forma escrita ou não realizado sob juramento.”309

A inserção deste princípio no sistema jurídico francês nascente se deu, sobretudo, e de forma mais específica, pela principal fonte sistematizada do Direito Costumeiro francês: Os Costumes e Usos dos Beauvaisian, escrito aproximadamente em 1283, que logo se transforma em obra de referência para os intendentes reais na aplicação do Direito em outras regiões francesas, no contexto de centralização política vivida na França de então,

\footnotetext{
${ }^{306}$ BÈZE, Théodore de. Du Droit des Magistrats. Genève: Droz, 1970, p. 17-18.

${ }^{307}$ Também denominado de Princípio da força obrigatória. Tal princípio "consubstancia-se na regra de que o contrato é lei entre as partes. Celebrado que seja, com observância de todos os pressupostos e requisitos à sua validade, deve ser executado pelas partes como se suas cláusulas fossem preceitos legais imperativos. O contrato obriga os contratantes, sejam quais forem as circunstâncias em que tenha de ser cumprido. Estipulado validamente seu conteúdo, vale dizer, definidos os direitos e obrigações de cada parte, as respectivas cláusulas têm, para os contratantes, força obrigatória. Diz-se que é intangível, para significar-se a irretratabilidade do acordo de vontades. Nenhuma consideração de equidade justificaria a revogação unilateral do contrato ou a alteração de suas cláusulas, que somente se permitem mediante novo concurso de vontades. O contrato importa restrição voluntária da liberdade; cria vínculo do qual nenhuma das partes pode desligar-se sob o fundamento de que a execução a arruinará ou de que não o teria estabelecido se houvesse previsto a alteração radical das circunstâncias. [...] Se aceitou condições contratuais extremamente desvantajosas, a presunção de que foram estipuladas livremente, impede que se socorra da autoridade judicial para obter a suavização, ou a liberação. Pacta sunt servanda. Ao Direito é indiferente a situação a que fique reduzido para cumprir a palavra dada." GOMES, Orlando. Contratos. Rio de Janeiro: Forense, 1996, p. 36.

${ }^{308}$ BERMAN, Harold J. Law and Revolution, The Formation of the Western Legal Tradition. v. I. Cambridge, Massachusetts \& London, England: Harvard University Press, 1983, p. 473.

${ }^{309}$ Ibidem, p. 247.
} 
disseminando o princípio do pacta sunt servanda e outros princípios contratuais também concebidos ou organizados pelos canonistas. ${ }^{310}$

Importa salientarmos que, apesar de Bèze evocar o princípio do pacta sunt servanda, no momento argumentativo que descreve a postura lícita de particulares diante de um tirano, já sinaliza os germes do direito de resistência, uma vez que descreve um contrato bilateral ou sinalagmático, ou seja, exige uma reciprocidade entre partes, ainda que, por ora, o reformador não explicite as obrigações dos governantes perante os governados, como explanará de forma clara em outros momentos argumentativos do tratado, ao discorrer sobre as vocações das magistraturas. No momento argumentativo ora em análise, Bèze não se furta a assinalar antecipadamente e de forma subentendida o dever dos reis de respeito aos consentimentos públicos.

Num segundo movimento argumentativo, Bèze avalia uma nova categoria de vocação, a dos magistrados inferiores e sua respectiva capacidade de atuação diante uma tirania manifesta.

Bèze compreende que tais magistrados são como um degrau subalterno entre $o$ soberano e o Povo. Esses cargos de natureza política (pertencentes ao próprio Estado, sendo afetados ao Reino e não ao Rei), numa monarquia, são denominados oficiais da Coroa e têm por encargo a administração da justiça, ou do fato da guerra, e não podem de forma alguma serem confundidos com simples oficiais da Casa Real, pelo grau de independência que os primeiros possuem quando comparados com os últimos. ${ }^{311}$

Em destaque na margem do tratado, Bèze averba: "Os magistrados subalternos de uma soberania devem em caso de uma tirania manifesta recorrer aos Estados (Gerais) e enquanto isso proteger os que estão sob seu encargo." ${ }^{312}$ Ou seja, a tese fundamental de Bèze quanto às magistraturas inferiores é a de haver certos agentes públicos que além de poder,

\footnotetext{
${ }^{310}$ BERMAN, Harold J. Op. cit p. 473-476. Berman assim descreve as lições de Beaumanoir sobre contratos: "Em contraste às cortes reais inglesas, os intendentes franceses possuíam jurisdição sobre contratos e não meramente sobre convenções seladas. Beaumanoir baseia essa jurisdição no princípio moral - declarado pelos canonistas - de que os contratos devem ser mantidos, pacta sunt servanda. "Todo contrato deve ser mantido", Beaumanoir escreve "e portanto está escrito 'um contrato prevalece sobre uma lei', exceto aqueles contratos realizados com maus propósitos, como por exemplo, se um contrata outro para matar um homem por 100 livres. Beaumanoir prossegue fazendo referências a outros princípios do direito contratual que eram geralmente aceitos pela Ciência jurídica romano-canônica: o contrato não pode ter sido feito por meio de força ou pressão; o objeto do contrato não pode ser impossível, ilegal ou imoral; dívidas contraídas em apostas de jogos e usura não são exigíveis; certas proibições devem ser banidas cabalmente no contrato (por exemplo, um vendedor abrir mão de qualquer direito de reclamação por ter recebido menos da metade do valor de sua propriedade). O que é interessante é que essas doutrinas da Ciência jurídica romano-canônica tinham tornado parte do direito costumeiro de Beauvais - e de outras regiões da França - aplicadas em outras cortes reais." BERMAN, Harold J. Op. cit, p. 476.

${ }^{311}$ BÈZE, Théodore de. Du Droit des Magistrats. Genève: Droz, 1970, p. 18.

${ }^{312}$ KINGDON, Robert M. Nota 12. In: BËZE, Théodore de. Op. cit., p. 18.
} 
têm o dever de neutralizar a atuação de um tirano manifesto sobre o povo, se os Estados Gerais não forem reunidos para dar a solução final para o problema.

Ao exemplificar o argumento, Bèze antecede os exemplos da História Sagrada, com exemplos da Roma Antiga. Mais uma vez, salienta-se assim o caráter de primazia secular, no trecho mais importante do tratado. Cita que na Roma Antiga, Cônsules, Pretores, Governador da Cidade, os Governadores das Províncias, escolhidos pelo povo ou pelo Senado, seja na época do Império ou da República, e por essa atribuição defensiva do povo, eram chamados de magistrados do povo ${ }^{313}$ e tinham tal função protetora.

Em Israel, Bèze identifica esta função nos Chefes das Doze Tribos, nos Anciãos do povo, nos Capitães dos coletivos de combatentes. Tal dinâmica de organização política instituída já por Moisés não fora modificada no momento em que o estado aristocrático se convertera em uma monarquia: "assim foi [a monarquia] arrumada e exatamente distribuída sob Salomão" "314. Para Bèze, portanto, mesmo o regime monárquico, e não apenas o aristocrático, apresenta compatibilidade com mecanismos de uma distribuição de poderes garantidora da não opressão do povo.

Nos vários reinos cristãos de sua época, atribui a função protetora do povo às suas magistraturas, ou vocação (numa nomenclatura mais teológica), aos Duques, Marqueses, Condes, Viscondes, Barões, Castelões, que outrora eram cargos públicos que se comissionavam por ordem legítima e, desde esse ato original de atribuição de poder pela soberania, tornaram-se dignidades hereditárias, o que em nada altera "a natureza de seu direito e autoridade". 315

Além da nobreza hereditária acima arrolada, o que muito demonstra a conveniência das teses de Bèze para a nobreza francesa convertida ao protestantismo, ${ }^{316}$ Bèze também atribuí a competência da resistência aos comandos ímpios e ilícitos dos tiranos aos oficiais eletivos das cidades como Prefeitos, Vigários, Síndicos, Escrivães, dentre outros semelhantes a estes. ${ }^{317}$

Nesse contexto é importante salientarmos o processo de centralização política da França, que desde a Baixa Idade Média vinha se consolidando, com o refluxo da autoridade regional da nobreza, sobretudo no que tange à administração da Justiça, e as funções de guerra, em detrimento da autoridade real centralizadora. Processo de centralização política em

\footnotetext{
${ }^{313}$ BÈZE, Théodore de. Op. cit., p. 18.

${ }^{314}$ Ibidem, p. 18.

315 Ibidem, p. 18.

${ }^{316}$ SKINNER, Quentin. As fundações do pensamento político. São Paulo: Cia das Letras, 2000, p. 576.

${ }^{317}$ BÈZE, Théodore de. Op. cit., p. 18.
} 
larga medida censurado por Bèze, uma vez que ele valoriza o protagonismo político dos oficiais eleitos das cidades, como também da nobreza regional.

Ele, Bèze, compõe um quadro de tensão entre o poder central, representado pelo Rei, sobretudo em sua capacidade de distribuir justiça, e os poderes regionais compostos pela nobreza e cidades com prerrogativas na França da Baixa Idade Média até os princípios da modernidade.

Após uma explanação denominativa abrangente desses cargos que compõem a magistratura defensiva, Bèze aponta o fundamento de tal autoridade, ao afirmar que: "Ora, é preciso entender que todos acima [os cargos supracitados], ainda que estejam abaixo de seu soberano (do qual recebem comando e o qual os instala e aprova), entretanto, não dependem propriamente do soberano, mas da soberania" ${ }^{318}$. Como prova do argumento acima transcrito, Bèze recorda o fato de que, na morte do soberano, esses mesmos magistrados continuam nos respectivos estados que ocupam, como também a soberania em nada se abala em sua integralidade. $^{319}$

Posto esse pano de fundo, no momento da sucessão da "administração da soberania", o novo soberano, ao se colocar na posse legítima de seu posto, jura fidelidade à soberania, "sob as condições postas em seu juramento", a esses oficiais do Reino, de forma que tal confirmação na sucessão do poder não necessita de um novo direito, mas do simples reconhecimento novo de um direito antigo, por causa da sucessão superveniente. ${ }^{320}$

Por tal motivo, haveria uma mútua obrigação entre um Rei e os oficiais de um Reino e, dessa maneira, no "Reino, todo o governo não é colocado entre as mãos do Rei; mas somente o soberano grau deste governo", devendo ser reconhecido que também "os oficiais inferiores têm cada um sua parte segundo seu grau", ou seja, parcela no poder. Por consequência, Bèze conclui que "o todo sob certas condições é uma parte e de outra", ou seja, seria logicamente impossível não se concordar com a partilha do exercício do poder soberano.

O desdobramento dessa dinâmica de obrigações recíprocas e partilha das funções da soberania gera a possibilidade de punição dos oficiais inferiores pelo rei, em conformidade com as leis do Reino, sob pena de este último contrariar seu juramento. Do mesmo modo, um rei, seja hereditário ou eletivo, caso se desviasse do cumprimento das condições assumidas ao ser coroado, nesta circunstância, restaria autorizada a quitação da obediência do magistrado inferior em relação a tal rei, e com fundamento no que lhe cabe da participação no exercício

\footnotetext{
${ }^{318}$ BÈZE, Théodore de. Du Droit des Magistrats. Genève: Droz, 1970, p. 19.

${ }^{319}$ Ibidem, p. 19.

${ }^{320}$ Ibidem, p. 19.
} 
das funções do poder soberano como um todo, seria lícito opor-se à "opressão manifesta do Reino"; do contrário, descumpriria seu juramento e dever de proteção "segundo seu cargo e particular administração" ${ }^{321}$.

Imediatamente após a apresentação de uma das possibilidades de resistência, pelo viés constitucionalista, Bèze, como num movimento pendular entre a possibilidade de resistência e o dever de obediência, já encontrado na escrita de Calvino, adverte, em última análise, sua oposição aos reformadores radicais, salientando sua recusa às sedições e conspirações, ao refutar a tese de que um soberano que, a priori é inviolável, torna-se, pela tirania manifesta, uma mera pessoa particular, passível de qualquer perseguição e de ofensa pública $^{322}$, num claro movimento de distanciamento do argumento de resistência fundamentado no direito privado, elaborado pelos juristas da Saxônia, na década de $1530 .^{323}$ Bèze atribui a essa categoria de vocação de magistraturas o dever de proteger aqueles que lhes são comissionados, ou seja a parcela geográfica do povo sob sua respectiva jurisdição, isso graças ao seu respectivo dever de conservar as leis. Salienta, porém, que a deposição dos tiranos, medida mais drástica, caberia apenas aos Estados Gerais. ${ }^{324}$

Quanto ao argumento do príncipe ser legibus solutus, Bèze responde que se trata de "um discurso muito falso, e de forma alguma pertencente a um súdito leal a seu Príncipe, mas a um detestável bajulador, dizer que os soberanos não são obrigados a nenhuma lei”,325; na margem do tratado destaca que: "Todo soberano é adstrito às leis de sua soberania.",326

Segundo Kantorowicz, tal concepção de vinculação do governante às leis consiste num lugar comum de tratados políticos do fim da Idade Média e início da Modernidade, graças a uma interpretação peculiar dos compiladores que, em seu sumário do Código de Justiniano, no século VI, sugeriram um vínculo mais estreito entre o imperador e a Lei, ao reproduzirem o édito: "É uma expressão digna da majestade do monarca que o Príncipe declare a si mesmo sujeito à Lei: nesta mesma medida depende nossa autoridade da autoridade da Lei. E, na verdade, maior que o imperium é a submissão do principado às leis. ${ }^{327} \mathrm{Na}$ verdade, as intenções dos instituidores de tal Lei eram bem mais modestas: "Os

\footnotetext{
${ }^{321}$ BÈZE, Théodore de. Du Droit des Magistrats. Genève: Droz, 1970, p. 19.

${ }^{322}$ Ibidem, p. 19.

${ }^{323}$ SKINNER, Quentin. As fundações do pensamento político. São Paulo: Cia das Letras, 2000, p. 474.

${ }^{324}$ BÈZE, Théodore de. Op. cit., p 20-21.

${ }^{325}$ Ibidem, p. 21.

${ }^{326}$ KINGDON, Robert M. Nota 25. In: BÈZE, Théodore de. Op. cit., p. 21.

${ }^{327}$ Compiladores de Justiniano apud KANTOROWICZ, Ernest H. Os Dois Corpos do Rei. São Paulo: Companhia das Letras, 1998, p.81.
} 
Imperadores Teodósio e Valentiniano, de quem emanava a lex digna ${ }^{328}$, haviam feito uma declaração implicando que, moralmente, o Príncipe estava obrigado a observar às leis pelas quais, legalmente, não estava sujeito; mas, por sua vez, não pretendiam sujeitar-se à Lei sem reservas ou negar a validade da afirmação segundo a qual o imperador era legibus solutus.”329

Bèze finaliza suas considerações sobre os magistrados inferiores, alegando que apesar de não terem o poder formal de destronar um tirano, podem se opor a ele, inclusive pelas armas, se exauridos os meios menos gravosos, com a finalidade de proteger aqueles que estão sob sua responsabilidade "não para fazer sedição, mas [justamente] para a impedir" de ser praticada pelo tirano que se desvia da obediência às leis. Mantendo o paralelismo argumentativo recorrente no manejo da historiografia, após expor eventos da Roma Clássica e da história de Israel, Bèze rememora um exemplo de sua época, ou que ao menos repercute intensamente nela: "Como também é notório que no tempo de nossos antepassados a tirania daqueles que dominavam sobre os Suíços deu abertura a seus magistrados municipais de promoverem a liberdade, da qual eles gozam." 330

A terceira categoria de súditos, analisada por Bèze seria "aqueles que (embora em verdade e em certo ponto de vista sejam submissos à obediência ao soberano) entretanto, de um outro ponto de vista e em caso de necessidade, são estabelecidos como Protetores dos direitos da soberania, para reter o soberano em seu dever, e mesmo o reprimir e castigar, se necessário for." ${ }^{, 331} \mathrm{Na}$ margem do tratado, Bèze destaca a tese referente a essa categoria de agentes políticos: "Os Estados [Gerais] ou outros ordenados para servir de freio aos soberanos podem e devem reprimi-los por todos as vias quando eles se tornam tiranos". 332

Além do elemento formal de vínculo pela via do contrato, que autoriza a responsabilização do governante, Bèze aponta um elemento de ordem material da relação entre o governante (que, apesar de denominado supremo magistrado, não se confunde com os magistrados habilitados para o combate da tirania) e seu povo, que seria o da funcionalidade da magistratura, ou seja, o Magistrado estaria para o povo e não o contrário. ${ }^{333}$

\footnotetext{
${ }^{328}$ A Lex Digna, da qual se vale Bèze, era sempre contraposta à Lex Regia, invocada pelos defensores da centralização do poder nas mãos do soberano, que declarava: "O Príncipe é livre da observação das leis, apesar da esposa do príncipe não seja livre disso, não obstante, os Príncipes podem comunicar os mesmos privilégios que possuem a ela.” GOTOFREDO, Dionisio; FREIESLEBEN, C. E.; VIGNALI, Giovanni. (org.) Corpo Del Diritto (Digesto). Edição Bilingue latim-italiano. Napoli: Vincenzo Pezzuti Editore, 1856, p. 110.

${ }^{329}$ KANTOROWICZ, Ernest H. Os Dois Corpos do Rei. São Paulo: Companhia das Letras, 1998, p. 81.

${ }^{330}$ BÈZE, Théodore de. Du Droit des Magistrats. Genève: Droz, 1970, p. 23.

${ }^{331}$ Ibidem, p. 23.

${ }^{332}$ KINGDON, Robert M. Nota 35. In: BÈZE, Théodore de. Op. cit., p. 23.

${ }^{333}$ BÈZE, Théodore de. Op.cit., p. 23-24.
} 
Remetendo-se mais uma vez à Roma Antiga, recorda que, apesar de parecer que Rômulo tenha criado o povo romano, Bèze contesta essa tradição mitológica e afirma que a leitura mais apropriada da origem de Roma é que tal povo fora "um amontoado de pessoas recolhidas de vários povos" e que, porém, só houvera domínio de Rômulo sobre essa gente graças ao seu consentimento. ${ }^{334}$

Dessa forma, Bèze entende que em toda organização política, "o poder dos Magistrados [Governantes], não importando quão grandes e soberanos sejam, depende do poder do público que os elegeu em seu grau e não o contrário"335, e já refuta a possível réplica de que, após o consentimento do povo, os Magistrados soberanos submetem seus povos incondicionalmente, alegando que as Nações somente criaram ou aceitaram reis sob certas condições e que, se as mesmas forem violadas, segue-se que: "aqueles que tiveram a autoridade de designar um governante, guardam o mesmo poder de privá-lo de tal condição."336

\subsection{Os treze exemplos universalizantes do direito de resistência institucionalizado}

O primeiro exemplo em que Bèze se detém é o do Estado dos Romanos: “comecemos pelo Reino, depois pelo Império dos Romanos, ainda que não tenham sido os mais antigos". Nosso autor exporá então, em seguida, os exemplos do Estado dos atenienses e da Lacedemônia, o que aponta para uma tentativa de construir a argumentação com um valor de universalidade, em detrimento de exposição simples e linear de instrumentos políticos que sirvam de controle dos governantes, entre diversos povos.

Outro elemento de justificativa para Bèze manter em todo o tratado um padrão de exposição preliminar da história de Roma, e depois outras organizações políticas, é o reconhecimento por parte do autor de ver nela os fundamentos do Reino da França. ${ }^{337}$

O sucessor de Calvino em Genebra, valendo-se, sobretudo, da narrativa de Tito Lívio em Ab Urbe Condita, demonstra, por uma série de eventos na história romana, que os governantes foram instituídos e destituídos pelo povo e pelo senado, além de serem vinculados às leis.

\footnotetext{
${ }^{334}$ BÈZE, Théodore de. Du Droit des Magistrats. Genève: Droz, 1970, p. 24.

${ }^{335}$ Ibidem, p. 24.

${ }^{336}$ Ibidem, p. 24.

${ }^{337}$ Ibidem, p. 25.
} 
Bèze inicia a narrativa, afirmando que o povo romano tinha engendrado, após a morte de Rômulo, um sistema político de "cem personagens que foram chamados Interreges" ${ }^{\text {338 }}$, ou seja, Entre-Reis, que governavam por rodízio, como a ideia não prosperou, houve um acordo, segundo o qual os Reis, dali em diante, seriam estabelecidos por sufrágios do povo, autorizados pelo Senado ${ }^{339}$.

Pautado em lições literais de Tito Lívio, sobretudo do Livro I de $A b$ Urbe Condit $^{340}$, Bèze mostra que o último rei Tarquínio, o Soberbo, fora feito rei pelo emprego de força, sem a acumulação dos requisitos de vontade popular e autorização do Senado. Ele era também o primeiro rei romano que se comportara de forma contrária aos costumes observados pelos reis precedentes, sem pedir Conselhos sobre todos os assuntos ao Senado. Tarquínio governava por conselhos particulares, declarando a guerra ou celebrando a paz, alianças ou associações ao seu alvitre, sem dar satisfações nem ao Povo, nem ao Senado.

Bèze conclui da narrativa de Tito Lívio sobre Tarquínio que "os Reis dos Romanos só foram recebidos sob certas condições, as quais, não sendo observadas, o Povo reunido em assembleia (conforme a distinção dos Cidadãos) não tinha menos poder de depor um Rei do que o de estabelecê-lo, como também o praticara [tal poder], na ocasião desse tirano." 341

Théodore de Bèze relembra que Sêneca, em Ad Lucilium Epistulae Morales (Livro II, XVIII) $^{342}$, nota que Cícero, em seu livro II, XVIII da República ${ }^{343}$, registra a possibilidade de se apelar de uma decisão do Rei ao Povo. Para ilustrar a assertiva, recorre mais uma vez à autoridade de Tito Lívio, em especial ao Livro I de Ab Urbe Condita ${ }^{344}$, que narra o caso de Horácio: uma vez envolvido numa causa criminal de assassinato de sua irmã, após ter sido condenado pelos juízes designados para o caso pelo Rei Tulo Hostílio, fora a posteriori absolvido pelo Povo. ${ }^{345}$

Bèze destaca também o fato de Rômulo, junto com seu Conselho, ter declarado ser o rei, o guardião das Leis. Ademais, foram delegadas ao Povo, as funções mais importantes como "o poder de criar os Magistrados, de estabelecer as leis, e ordenar a guerra:

\footnotetext{
${ }^{338}$ BÈZE, Théodore de. Du Droit des Magistrats. Genève: Droz, 1970, p. 24.

${ }^{339}$ Ibidem, p. 25.

${ }^{340}$ KINGDON, Robert M. Notas 2,3,4 e 6. In: BÈZE, Théodore de. Op. cit., p. 25.

${ }^{341}$ BÈZE, Théodore de. Op. Cit., p. 25.

${ }^{342}$ KINGDON, Robert M. Nota 5. In: BÈZE, Théodore de. Op. cit., p. 25.

${ }^{343}$ Ibidem, p. 25.

${ }^{344}$ Ibidem, p. 25.

${ }^{345}$ BÈZE, Théodore de. Op. cit., p. 25.
} 
o que parece, em verdade, ter servido como padrão aos fundadores da monarquia Francesa" 346 .

Da história de Colatino, primeiro cônsul com Brutus, conforme a narrativa de Tito Lívio (Livro II, II) ${ }^{347}$, o reformador extrai sua concepção de Povo. Apesar de afirmar que o Povo tinha igual autoridade sobre os cônsules, esclarece que se deve entender "sempre por essa palavra [Povo] não somente o Terceiro Estado que se chama hoje, mas os três Estados de Roma, a saber, os Patrícios, os Cavaleiros e o povo comum.”348

Outro paradigma de liberdade apontado por Bèze à época em que Roma fora governada pelos Decênviros, um governo colegiado de dez homens, consiste no fato de que era "lícito apelar da sentença de um a outro" 349 , de modo a deixar claro "que o poder não limitado de alguém nunca agradou ao povo romano, o qual constrangeu mesmo esses dez homens a se demitirem de seus cargos."

Em Tito Lívio (livro III, XXXIII), lê-se a seguinte descrição do itinerário do governo dos decênviros: "Com efeito, após um começo feliz, aqueles magistrados entregaram-se a excessos que lhes apressaram a queda, e o poder voltou às mãos de dois magistrados com o título de cônsules. ”351 . Como exemplo da moderação e prudência na época dos Decênviros, Tito Lívio assim descreve a dinâmica de poder, antes de sua degeneração:

De dez em dez dias cada um dos decênviros administrava a justiça. Naquele dia, dispunha de doze fasces, enquanto os outros decênviros tinham a suas ordens apenas um apparitor. Reinava absoluta concórdia entre eles. Essa harmonia poderia parecer perigosa a simples cidadãos, mas a equidade com que agiam em relação aos outros era perfeita. Para dar uma ideia de sua moderação bastará um único exemplo. Foi desenterrado um cadáver em casa de Públio Séstio, cidadão de família patrícia, e o apresentaram ao povo. Em detrimento de seu próprio poder, nunca uma causa em que era o legítimo juiz, cedeu esse direito ao povo para aumentar-lhe a liberdade. ${ }^{352}$

Quanto à figura de Ditador, Bèze a descreve como uma medida de exceção, que ocorria somente em caso de necessidade superveniente e por bem pouco tempo, num prazo de

\footnotetext{
${ }^{346}$ BÈZE, Théodore de. Op. Cit., p. 25.

${ }^{347}$ KINGDON, Robert M. Nota 8. In: BÈZE, Théodore de. Op. cit., p. 25-26.

${ }^{348}$ BÈZE, Théodore de. Op. Cit., p. 25-26.

${ }^{349}$ Ibidem, p. 26.

${ }^{350}$ Ibidem, p. 26.

${ }^{351}$ LÍVIO, Tito. História de Roma (Ab Urbe Condita Libri). São Paulo: Paumape, 1989, p. 244.

352 Ibidem, p. 245.
} 
seis meses e, mesmo assim, esse soberano poder exigia o consentimento do Povo ${ }^{353}$, naquela acepção anteriormente apontada.

Sobre a época dos imperadores, Bèze reafirma a existência de mecanismos de controle do poder, quer a priori, quer a posteriori, pois os imperadores deviam se submeter ao consentimento do Povo, e sempre houve mecanismos de reprimenda para quando se tornassem tiranos.

Dentre os exemplos dos imperadores citados por Bèze, destacamos o de Nero que "usurpou o Império com uma violência claramente manifesta, mas seu fim nos fornece um exemplo singular da autoridade que o Senado ainda tinha então, usando de seus direitos, que tinham por muito tempo adormecido." ${ }^{354}$

Esta passagem sobre o senado romano parece ser manifestamente alusiva aos Estados Gerais, pelo viés do anacronismo utilizado por Bèze, uma vez que é um lugar comum entre os calvinistas continentais a afirmação da autoridade dos Estados, mesmo que por muito tempo estes não fossem convocados. ${ }^{355}$

Por fim, Bèze afirma que sequer os imperadores romanos, pelos ditames do Direito, apesar de todo o poder que tinham, ficavam isentos de punição quando as circunstâncias exigiam: "Percebe-se que mesmo os Imperadores, tornados tiranos, podiam ser reprimidos e castigados pela via do direito no Império dos Césares." ${ }^{356}$

Quanto ao exemplo da Atenas do mundo clássico, Bèze afirma que sua Democracia fora transformada em Aristocracia; os testemunhos históricos da época descrevem a criação de um governo composto primeiramente de trinta homens e depois de dez homens: quando abusavam da autoridade a eles conferida, os atenienses valiam-se do mesmo direito que havia instituído esses governantes para destitui-los ${ }^{357}$.

No caso da Lacedemônia, Bèze ressalta o caráter de ser uma monarquia que combinava os fatores hereditário e eletivo, uma vez que "é algo muito notório que os Lacedemônios elegiam o Rei que os agradasse da família dos Heraclides." 358

Remetendo-se à autoridade de Plutarco, Bèze explica que como se não bastasse os reis serem eleitos e sob certas condições, os Lacedemônios ainda tinham os "Éforos estabelecidos para manter sob rédeas seus reis". Tais agentes políticos tinham o poder de

\footnotetext{
${ }^{353}$ BÈZE, Théodore de. Du Droit des Magistrats. Genève: Droz, 1970, p. 26.

${ }^{354}$ Ibidem, p. 27.

355 FRANKLIN, Julian H. Constitucionalism and resistance in the sixteenth century: the protestant monarchomachs. In: SPITZ, David. Political Theory and Social Change. New York: Atherton, 1967, p. 125.

${ }^{356}$ BÈZZ, Théodore de. Op. cit., p. 27.

${ }^{357}$ Ibidem, p. 27.

${ }^{358}$ Ibidem, p. 27.
} 
cassar e mesmo punir de forma capital os governantes. A liberdade deste povo é extinta com a supressão dos éforos, que foram traídos e condenados à morte pelo tirano Cleomenes. ${ }^{359}$

Por fim, ao narrar as práticas políticas dos lacedemônios, a obra de Xenofonte ${ }^{360}$ registra que: "O Rei e os Éforos se obrigam todos os meses por um juramento mútuo, a saber: os Éforos em nome de todos os Cidadãos, e Rei em seu próprio nome, jurando o Rei que reinará segundo as leis estabelecidas, e que os Éforos cuidarão da cidade, desde que ele mantenha seu juramento."

Dentre todos os exemplos, um dos mais recorrentes em toda literatura monarcômaca é o dos éforos, já citado por Calvino. Para Bèze, caberia a eles o poder de conter os reis em caso de abuso; em Hotman e Duplessis-Mornay, também lhes é reconhecido o poder positivo de elaborar as leis. ${ }^{362}$

Ao referir-se à organização política em Israel, ao longo da questão VI do tratado, Bèze o faz, atribuindo-lhe um caráter secular, uma vez que apesar desse povo ter tido o privilégio ímpar de possuir como rei o próprio Deus, voluntariamente se desfaz dessa dádiva. Como prova desse evento espetacular narra que "o Eterno só ele mesmo foi o monarca não somente na condição de ser Senhor soberano de todas as coisas, mas também de uma forma particular, tendo mesmo de forma visível dado as Leis para Moisés, e depois introduzido seu Povo por Josué na terra prometida, e finalmente governado por aqueles que só ele mesmo tinha imediatamente escolhido, que denominavam-se juízes. „363

Bèze ainda assevera, na oportunidade, que na hipótese de que todos os povos em todos os tempos se deixassem governar pelo Soberano de todo o mundo, seria reconhecido o caráter supérfluo de seu tratado, porém isso seria algo que sua época, segundo nosso autor, de forma alguma permitiria. Com efeito, se em outros povos a tirania teve origem por culpa do monarca, no caso de Israel a mesma causa seria impossível, pois tinha o povo por rei Aquele que jamais assim se portaria. ${ }^{364}$

\footnotetext{
${ }^{359}$ BÈZE, Théodore de. Du Droit des Magistrats. Genève: Droz, 1970, p. 28.

${ }^{360}$ Sobretudo o Livro XV, 7, da obra: Lakedaimonion Politeia, de Xenofonte. KINGDON, Robert M. Nota 3. In: BÈZE, Théodore de. Op. cit., p. 28.

${ }^{361}$ XENOFONTE. Lakedaimonion Politeia, apud BÈZE, Théodore de. Op. cit., p. 28.

${ }^{362}$ MELLET, Paulo-Alexis. Du Passé au Présent: Les Sources du Droit des Magistrats sur leurs Sujets (1574). In: BACKUS, Irena. Théodore de Bèze (1519-1605): Actes du Colloque de Genève (septembre 2005), Travaux d`Humanisme et Renaissance, CDXXIV. Genève: Droz, 2007, p. 544.

${ }^{363}$ BĖZE, Théodore de. Du Droit des Magistrats. Genève: Droz, 1970, p. 28.

${ }^{364}$ Ibidem, p. 29.
} 
A dispensa de tal dom particular da providência, para com esse povo, é para Bèze consentida pelo próprio Deus, em termos de uma provação para o povo ${ }^{365}$, conforme é narrado no Livro I de Samuel, 8, onde se lê :

Samuel, quando envelheceu, constituiu seus filhos juízes para Israel. O primogênito chamava-se Joel, e o segundo Abias: eles foram juízes, e Bersabéia. Mas seus filhos não seguiram o seu exemplo. Ao contrário, orientaram-se pela ganância, deixaram-se subornar e fizeram desviar o direito. Então todos os anciãos de Israel se reuniram e foram ao encontro de Samuel em Ramá. E disseram-lhe: 'Tu envelheceste, e os teus filhos não seguem o teu exemplo. Agora, portanto, constitui sobre nós um rei, que exerça a justiça entre nós, como acontece em todas as nações'. Mas esta expressão: 'Constitui sobre nós um rei, que exerça a justiça enttre nós', desagradou a Samuel, e então ele invocou Iahweh, que disse a Samuel: 'Atende a tudo o que te diz o povo, porque não é a ti que eles rejeitam, mas é a mim que eles rejeitam, porque não querem mais que eu reine sobre eles. Tudo o que têm feito comigo desde o dia em que os fiz subir do Egito até agora - abandonaram-me e serviram outros deuses - assim fizeram contigo. Agora, escuta a voz deles. Mas solenemente, lembra-lhes e explica-lhes o direito do rei que reinará sobre eles. ${ }^{366}$

Samuel, com o zelo característico de profeta, cumpre as determinações divinas e explica ao povo as consequências de rejeitarem a dádiva particularíssima de possuírem o próprio Deus como Rei. Ao fazê-lo, descreve circunstâncias de opressão universalmente válidas para qualquer tirania terrestre, sublinhando as pesadas obrigações de natureza tributária, de trabalho compulsório e militar a que se sujeitam aos reis facilmente degenerados e tiranos, da seguinte forma:

Samuel expôs todas as palavras de Iahweh ao povo, que lhe pedia um rei. Ele dissse: 'Este será o direito do rei que reinará sobre vós: Ele convocará os vossos filhos e os encarregará dos seus carros de guerra e de sua cavalaria e os fará correr à frente de seus carros. Ele tomará as vossas filhas para perfumistas, cozinheiras e padeiras. Tomará os vossos campos, as vossas vinhas, os vossos melhores olivais, e os dará a seus servos. Das vossas

\footnotetext{
${ }^{365}$ BÈZE, Théodore de. Du Droit des Magistrats. Genève: Droz, 1970, p. 29.

${ }^{366}$ I Samuel 1,8: 1-22. In: Bíblia de Jerusalém. São Paulo: Paulus, 2006, p. 399.
} 
sementes e das vossas vinhas ele cobrará o dízimo, que destinará aos seus eunucos e aos seus servos. Os melhores dentre vossos servos e vossas servas, e de vossos adolescentes, bem como vossos jumentos, ele os tomará para seu serviço. Exigirá o dízimo dos vossos rebanhos, e vós mesmos vos tornareis seus servos. Então, naquele dia, clamareis contra o rei que vós mesmos tiverdes escolhido, mas Iahweh não vos responderá, naquele dia!'

O povo, no entanto, recusou-se a atender a palavra de Samuel, e disse: 'Não! Nós teremos um rei e seremos, nós também, como as outras nações: o nosso rei nos julgará, irá a nosssa frente e fará as nossas guerras'. Samuel ouviu tudo o que o povo disse e contou ao ouvido de Iahweh. Mas Iahweh the respondeu: 'Escuta a voz deles e faz reinar sobre eles um rei.' Então Samuel disse aos homens de Israel: 'Volte cada um à sua cidade'. ${ }^{367}$

Mesmo possuindo reis comuns, desde então, ou seja, no momento em que os filhos de Samuel falham na função de governantes, ou nos termos bíblicos juízes, resta de tal evento um arranjo político-constitucional que torna tal povo ordinário como os demais povos da Terra em termos políticos, sendo capazes de eleger e punir reis por mecanismos institucionais, como fazem os Estados e os magistrados inferiores.

Os fundamentos para atuação de tais mecanismos de freio à licenciosidade dos Reis seriam acionados sempre que houvesse quebra do "juramento solene pelo qual o Rei e o Povo se obrigavam a Deus, a saber, à observação das suas leis tanto eclesiásticas quanto políticas, e depois, um outro juramento mútuo entre o Rei e o Povo. Mais precisamente dirá alguém: um Povo (quer dizer, os Estados desse povo) tinham também o direito de reprimir a pessoa que eles tinham escolhido para dominar, se esta não cumprisse seu dever? Eu digo que $\operatorname{sim}[\ldots] ., 368$

Para Bèze, Deus ordenou que a coroa fosse "hereditária pela casa de David", porém franqueou ao Povo, em sua plena discricionariedade, eleger, dentre os filhos do rei falecido, aquele que bem lhes parecesse, resguardada sob juramento a dupla obrigação da observação das leis políticas e religiosas.

O fundamento para tal juramento é extraído do Livro II Reis ${ }^{369}$, onde se lê: "Então Joiada mandou que trouxessem o filho do rei, cingiu-o com o diadema e entregou-lhe o

\footnotetext{
${ }^{367}$ I Samuel, 8: 1-22. In: Bíblia de Jerusalém. São Paulo: Paulus, 2006, p. 399-400.

${ }^{368}$ BÈZE, Théodore de. Du Droit des Magistrats. Genève: Droz, 1970, p. 30.

${ }^{369}$ KINGDON, Robert M. Nota 9. In: BEZZE, Théodore de. Op. cit., p. 30.
} 
documento da aliança ${ }^{370}$; proclamaram-no rei e deram-lhe a unção. Bateram palma e gritaram: 'Viva o rei !' [...] Joiada concluiu entre Iahweh e o povo uma aliança pela qual o povo se comprometia a ser o povo de Iahweh; e a aliança entre o rei e o povo. Todo o povo da terra dirigiu-se depois ao templo de Baal e o demoliu; quebraram totalmente os altares e as imagens e mataram Matã, sacerdote de Baal, diante dos altares."371

Para comprovar sua tese de que o desrespeito ao juramento feito permitia a punição do governante israelita, Bèze apresenta exemplos bíblicos, como a licitude do ato de Davi ao se defender contra a tirania de Saul, na condição de magistrado inferior; o contraste entre o assassinato licitamente perpetrado contra Amasias, conduzido às claras por uma liga geral em Jerusalém, considerada a parte principal dos Estados do Reino; as mortes não lícitas dos reis Joás e Amon, que foram perpetradas por servos domésticos. ${ }^{372} \mathrm{O}$ que mais uma vez mostra o caráter enfático de rechaço, da parte de Bèze, de uma participação popular direta na condução do direito de resistência.

De modo muito próximo ao de Calvino em seu capítulo XX, do Livro IV, da Instituição $^{373}$, que expõe a facilidade de degeneração da monarquia em tirania, no tópico sobre a política israelita, Bèze afirma que, apesar de Deus não condenar a monarquia a priori, não se deve esquecer que ela fora instituída na história do povo eleito como uma provação. Expondo a facilidade com que se transforma em uma tirania explica, já com uma fundamentação mais secularizada, que "uma coisa não se pode e nem se deve dissimular, a saber, que desde que o mundo é mundo, mesmo que peguemos os melhores Reis que jamais tenham existido, não se achará Rei que não tenha abusado de seu estado; de modo que é preciso se voltar àquilo que os Filósofos bem souberam conhecer por sua razão natural e com sagacidade, que o governo Monárquico é mais ruína de um povo do que a conservação". 374

Quanto à Dinamarca e Suécia, Bèze reafirma o princípio de supremacia da linhagem da casa real sobre o destinatário imediato da sucessão ao trono, podendo o povo, por seus representantes, substituir perfeitamente seus governantes nos parâmetros acima descritos.

No exemplo dinamarquês, Bèze explica que: "os Dinamarqueses depuseram e mantiveram preso até a morte Cristiano [II], Tirano muito cruel, transferindo seu Reino a um

\footnotetext{
${ }^{370}$ Pelos estudos expostos na Bíblia de Jerusalém, percebe-se a existência dessa aliança, ou algo similar, já entre egípcios e assírios: "Os reis de Judá recebiam, pois no momento de sua sagração, um documento da aliança celebrada entre Iahweh e a raça de Davi. Tem-se comparado com isso o "protocolo" redigido para os faraós no momento de sua coroação. O mesmo termo em aramaico e em assírio significa "estipulação da aliança". 2 Reis, 11: 12. Nota $h$. In: Bíblia de Jerusalém. São Paulo: Paulus, 2006, p. 522.

${ }^{371} 2$ Reis, 11: 12, 17-18. In: Bíblia de Jerusalém. São Paulo: Paulus, 2006, p. 522-523.

${ }^{372}$ BÈZE, Théodore de. BÈZE, Théodore de. Du Droit des Magistrats. Genève: Droz, 1970, p. 31-32.

${ }^{373}$ CALVINO, João. Lutero e Calvino, Sobre a Autoridade Secular. São Paulo: Martins Fontes, 2005. p. 86.

${ }^{374}$ BÈZE, Théodore de. Op. cit., p. 29.
} 
muito justo e sábio rei, seu parente próximo [Frederico I, tio do deposto] ${ }^{375}$, pai daquele que reina no presente." No caso, refere-se Bèze a Frederico II, que reinava na Dinamarca desde $1559 .^{376}$

Dos suecos, lembra que Gustavo I livrou seu povo do domínio dinamarquês, como também “ainda hoje possuem os suecos seu Rei prisioneiro [Erik XIV] ${ }^{377}$, por não ter tido sabedoria suficiente na administração de seu Reino, que fora transferido para seu irmão [João III] ${ }^{378}$, e que Deus lhe queria bem."379

Nesse processo de Reforma na Escandinávia, Skinner ressalta para o fato de ter sido a segunda região a aceitar o luteranismo, logo após regiões alemãs ${ }^{380}$, e Collinson destaca que, entre as monarquias, somente os estados escandinavos adotaram o luteranismo, e que por não ter havido pressão popular, ou seja, divergência entre os poderes constituídos e a população sob a jurisdição desses governos, tratou-se "de uma forma pura do cuius regio, eius religio" ${ }^{\text {381 }}$.Tal princípio norteador das relações entre o advento da Reforma e governo civil na Escandinávia remete-se à Paz de Augsburgo, celebrada em 25 de setembro de $1555^{382}$, que reconhecia no Sacro Império Romano a existência de duas crenças: católica e luterana, excluindo-se seguidores de Zwinglo, Calvino e anabatistas que habitavam a região. O conteúdo de reconhecimento implicava que "os governantes (eleitores, príncipes, duques e condes) têm o direito de determinar a religião de seus súditos, os quais, se não ficassem

\footnotetext{
375 KINGDON, Robert M. Nota 1. In: BÈZE, Théodore de. Op. cit., p. 32.

376 Ibidem, p. 32.

${ }^{377}$ KINGDON, Robert M. Nota 2. In: BÈZE, Théodore de. Op. cit., p. 32.

${ }^{378}$ Ibidem, p. 32

${ }^{379}$ BÈZE, Théodore de. Op. cit., p. 32.
}

380 Skinner narra de forma pormenorizada a evolução da Reforma protestante de conteúdo luterano na Escandinávia da seguinte forma: “A Escandinávia foi a região seguinte a adotar a nova fé. A Reforma começou deitando raízes na Dinamarca, depois que o duque de Schleswig-Holstein assumiu o trono, com o título de Frederico I, sucedendo, em 1523, a Cristiano II, que partira para o exílio. No Herredag por ele reunido em 1526, o novo rei desferiu um violento golpe no direito do papa ao confirmar os bispos dinamarqueses, e quatro anos mais tarde dava seu endosso aos 43 artigos fé luterana redigidos por Hans Tausen, 'o Lutero da Dinamarca'. Depois de uma guerra civil e de um interregno no início da década de 1530, a Coroa por fim veio ter ao reformador Cristiano III, em 1536. Esse príncipe prontamente afastou os bispos católicos, que haviam constituído o maior fator de resistência a sua ascensão ao trono, e assim completou oficialmente a Reforma, a qual então se viu imposta à Islândia e Noruega, que eram dependências da Dinamarca. Uma série análoga de acontecimentos se constata na Suécia, depois das vitórias de Gustavo Vasa na guerra de independência travada com a Dinamarca, em 1523. O primeiro passo oficial foi dado na Dieta de Vasteras, em 1527, quando pela primeira vez se permitiu livremente a pregação luterana. A Reforma se consumou numa dieta ulterior, de 1544, uma vez esmagada uma reação católica no Sul do país.". SKINNER, Quentin. As fundações do pensamento político. São Paulo: Cia das Letras, 2000, p. 302-303.

${ }^{381}$ COLLINSON, Patrick. A Reforma. Rio de Janeiro: Objetiva, 2006, p. 170.

${ }^{382}$ Em verdade a expressão cuius regio, eius religio surgiria apenas no século XVII, para explicar de forma sintética o significado da Paz de Augsburgo. COLLINSON, Patrick. Op. cit., p. 169. 
satisfeitos com a decisão tomada sem consultá-los, poderiam vender suas propriedades e emigrar.",383

Kingdon considera diretamente a Paz de Augsburgo como fruto dos feitos teóricos e práticos da resistência da cidade de Magdeburgo, perpetrada por luteranos, uma vez que tais atitudes inspiram o reagrupamento dos exércitos da Liga de Schmalkalden, acuando o governo imperial a aceitar a dualidade religiosa ${ }^{384}$.

Na sequencia de exemplos sobre a Escócia e a Inglaterra, Bèze traz à tona uma reflexão já em larga medida desenvolvida por outros autores calvinistas sobre o governo de mulheres, constituindo o próprio Bèze um ponto de mudança profunda na tradição teórica então nascente, marcada pela misoginia ${ }^{385}$. Em parte isto se deveu a uma necessidade de respostas imediatas para os problemas enfrentados pelos adeptos da nova fé.

Nos idos da década de 1550, a França, tendo por regente Catarina de Médici, a Escócia, tendo na mesma condição Maria de Guise, e a Inglaterra, elevando ao trono na qualidade de rainha Maria Tudor (Bloody Mary), compunham um quadro de governantes mulheres católicas, justamente nas áreas onde o calvinismo crescia como nova fé. Tais governantes, ao perseguirem o protestantismo em seus domínios, fazem com que, dentre vários refugiados, Estrasburgo acolha Jonh Ponet ${ }^{386}$ e Genebra, Christopher Goodman ${ }^{387}$ e Jonh Knox.

${ }^{383}$ COLLINSON, Patrick. A Reforma. Rio de Janeiro: Objetiva, 2006, p. 169.

${ }^{384}$ KINGDON, M. Robert. Calvinism and resistance theory, 1550-1580. In: BURNS, J. H.; GOLDIE, Mark. The Cambridge History of Political Thought, 1450-1700. Cambridge: Cambridge University Press, 2004, p. 202.

${ }^{385}$ KINGDON, M. Robert. Calvinism and resistance theory, 1550-1580. In: BURNS, J. H.; GOLDIE, Mark. The Cambridge History of Political Thought, 1450-1700. Cambridge: Cambridge University Press, 2004, p. 200.

${ }^{386}$ Jonh Ponet escreve e publica de forma anônima, em Estrasburgo, em 1556, uma das primeiras e mais radicais obras da teoria política calvinista, Breve Tratado sobre o Poder Político, que, apesar do título, objetiva mais propriamente um ataque à degeneração da igreja anglicana causada pelos bispos católicos, graças à restauração promovida por Maria Tudor. Não citando propriamente a rainha, critica, em termos vagos, os conselheiros espanhóis como estrangeiros interferindo nas posições do povo inglês. Seu escrito dá a impressão de que qualquer um pode perpetrar um ato de violência contra um tirano, sem a necessidade de uma qualificação especial para tanto, porém ao se valer da exemplificação histórica (éforos em Esparta, tribunos em Roma, membros do conselho ou dieta imperial na Alemanha, entre outros), deixa sugerida a necessidade dessa qualificação de agente público para tal. KINGDON, M. Robert. Calvinism and resistance theory, 1550-1580. In: KINGDON, M. Robert. Calvinism and resistance theory, 1550-1580. In: BURNS, J. H.; GOLDIE, Mark. The Cambridge History of Political Thought, 1450-1700. Cambridge: Cambridge University Press, 2004, p. 194196.

${ }^{387}$ Christopher Goodman publica em Genebra, em 1558, Como os poderes superiores devem ser obedecidos por seus súditos, tratado que, junto com escritos de Knox, marca uma alteração do alvo de críticas, que ultrapassam às direcionadas aos bispos católicos e conselheiros espanhóis, mas possuem como alvo principal Maria Tudor, num tom "histericamente" misógino, tratando a rainha como uma "bastarda de nascimento", contrariando as leis de herança, além de praticar deliberamente a idolatria. Consagrando o ensinamento bíblico do dever de se obedecer mais a Deus do que aos homens, entende que a soberana inglesa católica deve ser morta, podendo tal sentença ser executada por qualquer um que tenha a oportunidade para tal, e explicitamente refuta a limitação de tal direito a magistrados ou "oficiais inferiores", alegando que "o povo comum também" deve fazer seus príncipes obedecerm às leis de Deus. KINGDON, M. Robert. Op. cit., p. 196-197. 
Dentre todos os refugiados das nações insulares calvinistas, John Knox, o principal líder da Reforma escocesa, destaca-se como o mais misógino dos autores calvinistas refugiados no continente. Sua primeira e mais conhecida obra, de 1558, "O primeiro toque de trombeta contra o monstruoso governo de mulheres", constitui para Kingdon "um real clássico de misoginia, elegantemente organizado e desenvolvido com uma implacável lógica escolástica."

Em seu intento de demonstrar o monstruoso governo de mulheres, o líder da reforma escocesa apresenta três provas distintas: uma primeira derivada da natureza, apoiada em Aristóteles e no Corpus Iuris Civilis, que afirma serem as "mulheres inerentemente instáveis e então não devem possuir nenhuma autoridade política e judicial”. Uma segunda, extraída das Escrituras: “citando o Gênesis e São Paulo, sugere que o próprio Deus prefere que as mulheres sejam submetidas não apenas aos seus maridos, mas aos homens em geral”. E uma terceira prova de "ordem e equidade", que se dá através de uma "analogia orgânica, comparando a sociedade como um corpo e o homem a sua cabeça”. Deste modo, a conjugação das provas acima mencionadas levaria à conclusão de que é "um dever da nobreza e dos estados que tenham elegido mulheres como magistradas corrigir tal erro, depondo essas mulheres." 388

François Hotman, em seu tratado Franco-Gallia, expõe traços de misoginia quanto ao governo de mulheres, ao se perguntar se as mulheres estariam impedidas de administrar um reino, evidentemente pensando nas circunstâncias advindas durante a regência de Catarina de Médicis. ${ }^{389}$ Furta-se a uma resposta objetiva, responde que tal problemática não pode ser resolvida por uma lei geral, mas decidida caso a caso pelos Estados Gerais, resposta que, em última análise, presta-se a uma "Nova afirmação da prioridade institucional dos Estados." ${ }^{\text {,30 }}$ Porém, Hotman expõe na sequência "uma avalanche de casos históricos [...] para demonstrar que nenhum bem pode advir da colocação no poder de uma mulher, sobretudo se é uma rainha-mãe !"’391

Bèze, já no ano de 1560, ano que coincide com a coroação de Elizabete I, refuta as teses de que mulheres não possam ser boas governantes, inserindo a discussão numa segunda versão de Confissão da Fé Cristã, e nega claramente a forma de fundamentação bíblica

\footnotetext{
${ }^{388}$ KINGDON, M. Robert. Du Droit des Magistrats. Genève: Droz, 1970, p. 197.

389 PÉRIGOT, Béatrice. Du Droit des Magistrats de Théodore de Bèze et Franco-Gallia de François Hotman: Deux Méthodes au service da la Philosophie Politique. In: BACKUS, Irena. Théodore de Bèze (1519-1605): Actes du Colloque de Genève (septembre 2005), Travaux d'Humanisme et Renaissance, CDXXIV. Genève: Droz, 2007, p. 556.

${ }^{390}$ Ibidem, p. 556.

${ }^{391}$ Ibidem, p. 556.
} 
utilizada por Knox sobre a sujeição universal das mulheres aos homens, principalmente na ocasião de se decidir quem deve governar um reino. ${ }^{392}$

O nosso autor, nessa obra de 1560, inicia a colocação do problema afirmando que os homens souberam preservar seu estado sabiamente, ao ponto de que "ordenaram que as mulheres não viessem jamais a reinar" ${ }^{393}$. Porém, adverte que Deus não havia posto isso de forma precisa e que Ele próprio "para castigar a covardia e o coração efeminado dos homens, abençoou frequentemente tais dominações de mulheres." ${ }^{394}$ Além disso, reconhece os absurdos que adviriam caso as mulheres fossem absolutamente sujeitas aos homens: "as mães não terão poder sobre seus filhos homens, as filhas não poderão suceder aos seus pais em feudos nobres, e antigamente as mulheres não teriam tido (de bom direito) nenhum poder sobre seus servos homens $[\ldots]$ "..395

No caso de elevação das mulheres à condição de rainhas, para refutar a utilização de argumentos extraídos do Gênesis por John Knox, relembra que, particularmente nesse trecho, Deus se referiria às esposas em relação à sujeição aos seus respectivos maridos, e que de forma alguma disso se possa extrair uma regra universal de sujeição absoluta das mulheres aos homens, a ponto de se impedir que mulheres se tornem rainhas, conforme explica:

Assim, então, eu vos peço, em locais onde os Reinos são hereditários pelo consentimento do povo, ou expressamente declarado, ou tacitamente decidido, por que diremos se uma mulher vier a ser herdeira que haja vício na coisa, simplesmente? Pois quanto ao que se alega de Moisés, da dominação do homem estabelecida sobre a mulher desde a queda de Adão, isso não vem ao caso, visto que o Senhor fala aí da sujeição que somente ocorre no matrimônio; o que aparece em parte sobre a circunstância do trecho, já que ali se faz menção até ao parto, em parte pelas palavras que o Senhor mesmo usa.

Pois ele não diz simplesmente 'tua vontade será sujeita ao homem', mas 'tua vontade será sujeita a teu marido, e este terá dominação sobre ti' ${ }^{396}$

\footnotetext{
${ }^{392}$ KINGDON, M. Robert. Calvinism and resistance theory, 1550-1580. In: KINGDON, M. Robert. Calvinism and resistance theory, 1550-1580. In: BURNS, J. H.; GOLDIE, Mark. The Cambridge History of Political Thought, 1450-1700. Cambridge: Cambridge University Press, 2004, p. 200.

393 BËZE, Théodore de. Confession de la foi chrestienne. $2^{\circ}$ version (1560 et ss.), Point V, article XLV. (Apêndice II) In: BÈZE, Théodore de. Du Droit des Magistrats. Genève: Droz, 1970, p. 71.

${ }^{394}$ BÈZE, Théodore de. Confession de la foi chrestienne, $2^{\circ}$ version (1560 et ss.), Point V, article XLV. (Apêndice II) In: BÈZE, Théodore de. Du Droit des Magistrats. Genève: Droz, 1970, p. 71.

395 Ibidem, p. 71.

${ }^{396}$ Ibidem, p. 71-72.
} 
Em Du droit des Magistrats, Bèze, em tom de desprezo, e caprichosamente, não se dignando a citar o nome de Maria Stuart, celebra o fato de "os escoceses nesses anos recém-passados terem deposto e condenado à prisão perpétua sua Rainha, acusada de vários adultérios cheios de vilania e do assassinato muito cruel do Rei seu marido ${ }^{397}$; e se essa acusação for bem verificada, eu ouso dizer que eles fizeram muito bem em puni-la segundo seus deméritos."

Sobre o reino do Sul da Grã-Bretanha, chama a Inglaterra de "o mais feliz dos reinos que exista hoje, e que queira Deus manter, em sua tranquilidade, e ainda que seja um reino sucessivo ao mais próximo do Príncipe de sangue, percebe-se por muitas memoráveis histórias, e notadamente pelo testemunho de Polydore ${ }^{399}$ sobre a vida de Henrique primeiro no nome, que a autoridade de reinar é fundada em maior parte sob o consentimento do Parlamento que eles convocam." 400 Ou seja, constitui a Inglaterra também como um exemplo antigo no esforço de se provar a tese de universalidade da limitação do poder real por corpos legislativos.

Especificamente sobre Elizabete I, Bèze a coloca como responsável pelo feliz descanso que goza o reino inglês, uma vez que "há vários anos, sob o muito benevolente e bendito governo de sua sereníssima Rainha Elizabete, quando comparado com o pobre estado de tantos outros países, mostra pela experiência o quanto é feliz e proveitosa uma tal moderação do poder Real, desde que ele seja bem praticado e que os Reis temam a Deus [...].",401

Apesar dos esforços de Bèze, desde seu catecismo da fé calvinista, de 1560, e depois em seu tratado político principal, de 1574, de angariar a simpatia da soberana inglesa, a mesma sempre foi refratária a uma aproximação política com os calvinistas ${ }^{402}$, mesmo em termos devocionais. Apesar de o parlamento inglês exigir que o conteúdo da fé da igreja anglicana fosse gradativamente se aproximando do calvinismo, é certo que Elizabete possuía

\footnotetext{
${ }^{397}$ O marido de Maria Stuart, que Bèze faz referência, trata-se de seu segundo marido Lorde Darnley. 398 BÈZE, Théodore de. Op. cit., 1970, p. 33.

${ }^{399}$ Segundo Kingdon, trata-se de Polydore Vergile, cuja Anglica Historia, em seu livro XI versa sobre Henrique I. KINGDON, Robert M. Nota 1. In: BÈZE, Théodore de. Op. cit., p. 33.

${ }^{400}$ BÈZE, Théodore de. Op. cit., p. 33.

401 Ibidem, p. 33.

${ }^{402}$ Calvino, em 1559, ao preparar uma revisão de seu Comentário sobre Isaías, envia a nova edição com uma carta de saudação para a nova rainha inglesa. Seu emissário lhe responde que a homenagem não fora bem aceita por Elizabete, pois ela censurava o fato de Calvino ter permitido a impressão em Genebra das críticas de Knox ao governo de mulheres. SKINNER, Quentin. As fundações do pensamento político. São Paulo: Cia das Letras, 2000, p. 491-492.
} 
uma fé protestante sim, contudo mais próxima ao luteranismo. ${ }^{403}$ Isso, sem sombra de dúvidas, deve-se aos toques das trombetas, tocadas por Knox e outros calvinistas que, ao terem em mente rainhas ou regentes católicas como alvos de seus ataques, farão com que jamais os calvinistas consigam obter a confiança da primeira mulher rainha e protestante.

Além do mais, como é de se esperar, os exemplos da Escócia e da Inglaterra trazem a reafirmação da responsabilidade dos governantes, não importando seu gênero. No caso de Mary Stuart, um controle a posteriori e, no caso de Elizabete, a afirmativa do controle parlamentar prévio.

Dentre todos os exemplos citados por Bèze, talvez o que melhor comprove sua argumentação pautada no constitucionalismo como posição neutra para a discussão política capaz de salvaguardar o movimento reformador francês sem apelar para questões religiosas, com a faculdade de inclusive captar a simpatia ou ao menos um espaço de negociação com o partido católico moderado (segundo a concepção geral de Skinner sobre a literatura calvinista continental do século XVI) ${ }^{404}$, seja o da Polônia.

Além do mais, destaca-se a atuação diplomática de Bèze no delicado concerto europeu de então ${ }^{405}$, em que a questão da nova fé reformada tornava-se uma problemática supranacional, para os estados-nações que lentamente se organizavam, sobretudo no caso da Polônia. Destacamos tal atuação, pois durante a dieta da eleição do novo rei na primeira metade da década de 1570, ocasião em que a coroa francesa tentava, conforme as predileções de Catarina de Médici, eleger rei da Polônia Henrique, duque d'Anjou, irmão de Carlos IX, e para isto, necessitava a regente francesa negociar com ministros protestantes da Polônia ${ }^{406}$, que por sua vez eram aconselhados por cartas e emissários de Genebra.

Para prover a defesa perante a dieta do candidato francês, fora designado o bispo de Valência, Jean de Monluc, que segundo o partido francês protestante teria sido um dos grandes articuladores da noite de São Bartolomeu. Apesar disso, Bèze aponta que em um de

\footnotetext{
${ }^{403}$ Sobre as convicções religiosas de Elizabete, Collinson as descreve como: "certamente não eram apaixonadamente protestantes: ela não era calvinista, e na verdade sua evidente crença em algum tipo de presença real de Cristo [na Santa Ceia] a colocava mais próxima do Luteranismo.”, como também é possível encontrar traços de catolicismo, pois: "Costumava usar expressões católicas já fora de moda, como 'Pelo Corpo de Cristo!', que faziam gelar o sangue dos protestantes mais estritos. Tinha simpatia pelas imagens que os protestantes queriam destruir. Se não fosse por ela, é possível que as grandes catedrais da Inglaterra tivessem tido o mesmo fim dos mosteiros, e com elas a importante tradição da música sacra inglesa. Elizabeth parece haver preferido o antiquado celibato do clero." COLLINSON, Patrick. A Reforma. Rio de Janeiro: Objetiva, 2006, p. 159.

${ }^{404}$ SKINNER, Quentin. As fundações do pensamento político. São Paulo: Cia das Letras, 2000, p. 576.

${ }^{405}$ Kingdon aponta que os negócios poloneses nesse período ocupam demasiadamente a correspondência de Bèze, sobretudo com Bullinger, expoente da Igreja reformada em Zurich. KINGDON, Robert M. Introdução. In: BÈZE, Théodore de. Du Droit des Magistrats. Genève: Droz, 1970, p. XVIII.

${ }^{406}$ KINGDON, Robert M. Op. cit., p. XVIII.
} 
seus discursos haveria o reconhecimento (portanto do partido católico adversário da França) da validade de sua tese quanto ao comprometimento dos reis às leis, por ocasião de sua eleição.

Nas tratativas prévias da eleição, possuindo amplos poderes como procurador da coroa francesa, o bispo valenciano cede em vários pontos às reivindicações protestantes ao ponto que, quando eleito o duque d’Anjou, recusa-se a partir para a Polônia, renunciando ao direito adquirido na eleição de ser rei. ${ }^{407}$

Posta essa realidade das circunstâncias políticas vividas por Bèze como um dos articuladores das reivindicações dos protestantes ${ }^{408}$, o nosso autor descreve em seu tratado como os poloneses, sendo um povo que elege seus Reis sob certas condições, e caso o mesmo não observe o juramento celebrado, estão desobrigados de obedecê-lo. Realidade que não poderia ser mais posta em dúvida desde "a última eleição em que fizeram de Henrique [Rei], irmão do Rei da França". 409

Como fonte de autoridade para sua tese cita o próprio mediador do partido oposto, o bispo valenciano, que em "seu discurso pomposo impresso" ${ }^{\text {410 }} \mathrm{diz}$ que os poloneses "tem assim bem regulado e limitado o poder de seus Reis" ${ }^{\text {"11 }}$, ou seja, com a declaração do procurador da coroa francesa, restaria reconhecida de forma inequívoca a validade universal das teses constitucionais de Bèze, limitadoras dos governantes, já que foram passíveis de reconhecimento por um membro do partido adversário ao de Bèze.

Uma crítica a esses mecanismos de controle do poder, sobretudo pela nobreza, que são tão celebrados por Bèze, é elaborada por outro pensador clássico da filosofia política, também associado à Genebra e suas virtudes republicanas. Trata-se de J. J. Rousseau, que aproximadamente dois séculos após a publicação do tratado de Bèze, escreve um ensaio com o sugestivo título de: Considerações sobre o Governo da Polônia e sua Reforma Projetada. Ao fazer um diagnóstico da evolução histórica das práticas políticas dos poloneses, Rousseau parte da seguinte percepção: na Polônia haveria três classes: "os nobres, que são tudo; os

\footnotetext{
${ }^{407}$ KINGDON, Robert M. Introdução. In: BÈZE, Théodore de. Du Droit des Magistrats. Genève: Droz, 1970, p. XVIII-XIX.

${ }^{408}$ Genebra credencia e instrui o nobre huguenote Rémon, barão de Thyr, após requisição das igrejas reformadas da Polônia, para as negociações da eleição polonesa, porém o mesmo chega tarde demais para exercer qualquer influência. Ibidem, p. XVIII-XIX.

${ }^{409}$ BËZE, Théodore de. Du Droit des Magistrats. Genève: Droz, 1970, p. 33.

${ }^{410}$ Kingdon especula que a impressão do discurso Oratio ad ordines Poloniae in electione novi Regis, citada por Bèze provavelmente seria de 1573, de Cracóvia, havendo também ao menos "uma outra edição e traduções francesas, também impressas em 1573, mas na França, provavelmente depois da redação de Du droit des magistrats.” KINGDON, Robert M. Nota 2. In: BÈZE, Théodore de. Du Droit des Magistrats. Genève: Droz, 1970, p. 34.

${ }^{411}$ BËZE, Théodore de. Op. cit., p. 34.
} 
burgueses, que não são nada; e os camponeses que são menos que nada."412. Apesar de reconhecer a eleição como meio de manter a liberdade, nota que no caso polonês cada reino se vale desse mecanismo para abalar o Estado como um todo ${ }^{413}$ e esclarece que o grande problema da Polônia seria o excessivo mecanismo de controle sobre o Poder Executivo, sobretudo por parte da nobreza, de modo a obstruir qualquer possibilidade de se governar com tantos freios, elegendo como o pior deles o liberum veto ${ }^{414}$, uma vez que por tal instrumento exigia-se a unanimidade para as decisões políticas do corpo representativo polonês.

Gustave Pétitain, em sua Notícia Preliminar, uma concisa história da Polônia que acompanha a obra de Rousseau ora em tela, desde as primeiras edições ${ }^{415}$, explica a forma abusiva pela qual a nobreza polonesa há séculos se valia de suas prerrogativas de representação nas Dietas polonesas (que seriam análogas aos Estados Gerais franceses):

Os nobres apenas, gozando assim dos direitos de cidade, reuniram-se periodicamente nas dietinas, ou 'dietas' de palatinado, para nelas eleger os 'núncios' encarregados de representá-la na dieta geral. Esta se reunia a cada dois anos e era composta do senado e dos representantes da nobreza; ela partilhava com o rei o poder legislativo.

A este germe sempre subsistente de confusão e de desordem acrescentavamse: 1) a dependência absoluta de cada núncio, resultando das instruções que lhe haviam sido dadas na dietina e da qual ele não podia se afastar; 2) o direito do liberum veto que tornava a deliberação de toda e qualquer dieta infrutuosa pela oposição de um só membro, direito cujo uso não podia ser situado para além de 1650, mas de que os nobres poloneses se tinham desde então mostrado tão ciosos que ele se convertera em lei máxima do Estado. ${ }^{416}$

Em suma, a virtuosa forma aristocrática de governo da Polônia, descrita por Bèze no século XVI, com eficazes mecanismos de controle do poder real, principalmente na oportunidade das eleições do rei pela nobreza, é posta em xeque por autores posteriores como J. J. Rousseau e Pétitain, ao explicitarem sua degeneração numa oligarquia, que criava

\footnotetext{
${ }^{412}$ ROUSSeaU, J. J. Considerações sobre o Governo da Polônia e sua Reforma Projetada. São Paulo: Brasiliense, 1982, p. 42.

413 Ibidem, p. 99.

${ }^{414}$ Ibidem, p. 48-49.

${ }^{415}$ FORTES, Luiz Roberto Salinas. Nota 1. In: ROUSSEAU, J. J. Op. Cit., p. 17.

${ }^{416}$ PÉTITAIN, Gustave. Notícia Preliminar. In: ROUSSEAU, J. J. Op. Cit. p. 18.
} 
obstáculos para os instrumentos decisórios do Estado, ao impor a unanimidade na deliberação dos corpos legislativos.

Dentre todos os exemplos históricos paradigmáticos selecionados e esmiuçados por Bèze, talvez não haja um mais conveniente para seus propósitos de arquitetar um governo na França limitado pela nobreza e sem influências do papado do que o de Veneza.

Refere-se a tal república como a melhor conduzida pela "prudência humana" ${ }^{417}$, uma vez que tal povo itálico elege um Duque soberano por via de um Conselho Geral, possuidor também da competência para depô-lo e puni-lo, caso empreenda algum ato de tirania. $^{418}$

O regime constitucional dessa "sereníssima república"419 é descrito por Giuseppe Galasso como um sistema político munido de mecanismos que impedem o exercício do poder unilateralmente pelo Doge, uma família, uma facção ou mesmo uma das instituições que compõem essa complexa comunidade política ${ }^{420}$, da seguinte forma:

A base aristocrática do estado veneziano é fisicamente expressa pelo Conselho Maior, a assembleia do patriciado formada pelas famílias registradas como nobres em 1297 , às quais é exclusivamente reservada a plenitude dos direitos políticos. O Conselho Maior é, do ponto de vista do direito, o verdadeiro soberano da república. Mas a particularidade do desenvolvimento institucional de Veneza é dada pelo fato de que o poder é objeto de um processo extremamente complicado de delegações,

\footnotetext{
${ }^{417}$ BÈZZ, Théodore de. Du Droit des Magistrats. Genève: Droz, 1970, p. 34.

${ }^{418}$ Ibidem, p. 34.

419 Skinner coloca que, após o governo estabelecido em 1297, alicerçado no Consiglio Grande, o Senado e o Doge compõem um "sistema rigidamente oligárquico", desencadeando uma série de rebeliões populares, contidas pela instituição do Conselho dos Dez "como um órgão secreto e permanente de segurança pública". O que permite Veneza viver desde 1335 um "período de liberdade e segurança que não conheceu novas interrupções, despertando a inveja de toda a Itália e desfrutando de reputação tão excepcional que se tornou conhecida como República Sereníssima." (SKINNER, Quentin. As fundações do pensamento político. São Paulo: Cia das Letras, 2000, p. 160). Jacob Bruckhardt, em seu clássico ensaio sobre o Renascimento italiano, expõe o agudo contraste entre os dois mais importantes modelos de República fornecidos pelo período, Florença, e seu embate entre as facções e Veneza, com sua tranquilidade política: "Dentre as cidades que preservaram sua independência, duas são da maior importância para toda a história da humanidade: Florença - a cidade em constante movimento, que nos legou testemunho de todas as ideias e propósitos individuais e coletivos daqueles que, ao longo de três séculos, tomaram parte nesse movimento - e Veneza - a cidade da aparente ausência de movimento e do silêncio político. A contraposição das duas revela os mais gritantes constrastes imagináveis; ambas, porém, não admitem comparação com nada neste mundo.” BURCKHARDT, Jacob. A Cultura do Renascimento na Itália. São Paulo: Cia das Letras, 1991,. p. 62.

${ }^{420}$ GALASSO, Giuseppe. Poder e Instituições em Itália, Da queda do Império Romano aos nossos dias. Lisboa: Livraria Bertrand, 1984, p.186.
} 
participações várias, controles e interferências recíprocas, articulados numa série de órgãos $[\ldots]^{421}$,

que esquematicamente seriam:

[...] três Conselhos, um eleitoral soberano (o Conselho Maior), um deliberante em sede legislativa, política e administrativa (o Senado), um com funções de supremo tribunal de justiça e de vigilância da segurança do estado (o Conselho dos Dez); dois órgãos executivos, um técnico, consultivo e de direção burocrática (os "Sábios”), e um essencialmente político e com as funções de representação oficial do estado (Senhoria); um órgão judicial ordinário e com funções de seleção e de controle para a admissão ao órgão eleitoral soberano (a Quarantia). ${ }^{422}$

William J. Bouwsma aponta, para além de uma pouca interferência da Igreja Romana nos negócios públicos dessa República, até mesmo uma interferência contrária do próprio Conselho em relação à igreja católica local, que uma das razões para tal peculiaridade nas organizações das comunidades políticas europeias da Baixa Idade Média até o Renascimento seria a construção mítica de que a igreja veneziana possuía um apostolado paralelo ao romano, fundado pelo próprio São Marcos e que, portanto, nunca teria reconhecido a supremacia de São Pedro em Roma. Tal construção mitológica é assim descrita por Bouwsma:

Mas o mais importante elemento na tradição eclesiástica veneziana foi o apelo para sua substancial autonomia que em paralelo reforçava a autonomia política veneziana. Assim como Veneza insistia em sua liberdade em relação ao imperador nos negócios temporais, também ela insistia - quase tão firmemente - em sua liberdade do papa nos negócios da Igreja. Tal apelo era profundamente baseado em um mito: que a Cristandade tinha sido plantada nos canais venezianos pelo próprio São Marcos. Essa lenda, que viria a se tornar mais um dos férteis lugares comuns da historiografia veneziana,

\footnotetext{
${ }^{421}$ GALASSO, Giuseppe. Poder e Instituições em Itália, Da queda do Império Romano aos nossos dias. Lisboa: Livraria Bertrand, 1984, Ibidem, p. 183.

${ }^{422}$ Ibidem, p. 185.
} 
conferiu à igreja veneziana uma fundação apostólica independente e paralela à de Roma e em alguma medida reconhecida pelo papado. ${ }^{423}$

Trata-se de uma das construções históricas legitimadoras de sua liberdade frente ao papado ou ao imperador, das várias que Veneza atribui a si, em seu percurso constitucional, sendo inclusive tal atitude fabulosa sobre seu passado uma das mais importantes fontes para concepção do Estado moderno em termos gerais, conforme explica F. Gaeta:

A história de Veneza e seu desenvolvimento constitucional fora deliberadamente alterada pela tradição das crônicas venezianas. Porém, são precisamente e paradoxalmente essas deformações da realidade histórica que revelam uma concepção moderna de Estado. O mito da liberdade original aquela que é a forma pela qual ele se realiza - marca a preocupação de apresentar um estudo que seja um organismo jurídico primário e soberano, dotado de uma via constitucional inteiramente autônoma, não dependendo de qualquer outro poder, qualquer que ele seja. ${ }^{424}$

Ainda sobre o exemplo republicano de Veneza arrolado por Bèze, é oportuna a referência do símbolo de república renascentista contraposta à republica christiana, esta última, síntese do pensamento político medieval ${ }^{425}$, da qual os aspectos de interferências e promiscuidade entre a autoridade religiosa papal e os governos temporais eram com frequência combatidos pelos reformadores do século XVI que se debruçaram sobre o problema político.

Por republica christiana entende-se a concepção medieval de unidade de todos os cristãos num único corpo, cuja expressão era intercambiável com a palavra ecclesia inclusive, segundo Jacobus de Viterbo, somente a Igreja poderia ser a vera respublica, pois somente ela teria condições reais de promover o bem comum, pelo simples fato de estar em contato direto com a fonte última de todas as dádivas, de modo que todo poder temporal devesse

\footnotetext{
${ }^{423}$ BOUWSMA, William J. Venice and the Defense of Republican Liberty. Berkeley \& Los Angeles: University of California Press, 1984, p. 73-74.

${ }^{424}$ GAETA, F. La Naissance de 1'Etat Moderne em Italie: Milan ou Venise? In: Théorie et Pratique Politique a la Renaissance. Paris: Libraire Philosophique J. Vrin, 1977, p. 465.

${ }^{425}$ Ibidem, p. 8.
} 
necessariamente submeter-se à igreja católica, compondo relações políticas extremamente hierarquizadas. $^{426}$

Já o republicanismo renascentista possuía por centro de suas concepções a liberdade compreendida como repúdio à subordinação de modo que:

uma verdadeira república era em primeiro lugar um poder singular, não participante de um sistema dirigido por uma autoridade superior; que pretende ter o direito de determinar suas próprias políticas simplesmente baseadas em seus interesses particulares. Como também não era sua estrutura interna sistemática no sentido medieval, não sendo comandada para um fim singular, de cima para baixo, por um príncipe, mas por um corpo de cidadãos que, de alguma forma, representava a comunidade e seus interesses, relacionando-se uns com os outros por um princípio bem diferente do da hierarquia. $^{427}$

Ao finalizar a abordagem sobre Veneza, Bèze faz uma conclusão nos seguintes termos: "Agora é a vez de vários outros povos da Itália, fazendo pose de serem grandes fazedores de discursos das coisas desse mundo, até o ponto de fazerem livros, considerar em si mesmos, se foram tão sábios quanto os venezianos." ${ }^{428}$. Segundo Kingdon, trata-se de uma alusão pejorativa aos florentinos Maquiavel e Guicciardini. ${ }^{429}$

Nesse contexto, Bèze expressa um lugar comum entre as obras políticas calvinistas que é o anti-maquiavelismo, percepção sobretudo vinculada à figura de Catarina de Médici, a senhora serpente, que fora por tais autores considerada uma mentora da noite de São Bartolomeu, regente então da França, cujo bisavô, Lourenço de Médici, o magnífico, fora agraciado com a dedicatória de $O$ Príncipe.

Dentre as obras protestantes, a que mais especificamente atribuí o massacre como perpetrado nos moldes de uma conspiração maquiavélica seria Anti-Maquiavel de Innocent Gentillet, um nobre huguenote refugiado em Genebra, após sobreviver aos massacres. ${ }^{430} \mathrm{As}$

\footnotetext{
${ }^{426}$ GAETA, F. La Naissance de l`Etat Moderne em Italie: Milan ou Venise? In: Théorie et Pratique Politique a la Renaissance. Paris: Libraire Philosophique J. Vrin, 1977, p. 6.

${ }^{427}$ Ibidem, p. 11.

${ }^{428}$ BÈZE, Théodore de. Du Droit des Magistrats. Genève: Droz, 1970, p. 34.

${ }^{429}$ KINGDON, Robert M. Nota 2. In: BEZZE, Théodore de. Op. cit., p. 34.

${ }^{430}$ COLLINSON, Patrick. A Reforma. Rio de Janeiro: Objetiva, 2006, p. 184.
} 
primeiras versões da obra são praticamente contemporâneas à publicação de $D u$ droit de Magistrats, de Bèze. ${ }^{431}$

Porém, apesar da recepção estigmatizada e reducionista da fortuna crítica da obra de Innocent Gentillet, que unilateralmente faz a mesma ser lembrada como um instrumento teórico contra Maquiavel, ignora-se o fato de que ela aborda questões importantes e recorrentes aos tratados políticos do século XVI ("a soberania do povo, a teoria do contrato e a tolerância religiosa" ${ }^{432}$ ), na conturbada França envolta em conflitos religiosos. ${ }^{433}$

No caso da Espanha, Bèze emite um juízo de lamento e não menos pejorativo quanto à sua formação, pois por muito tempo recebera como um dilúvio diversos povos bárbaros setentrionais e da África. Ainda que reconheça como verdadeira a lição de Aristóteles, de que os bárbaros possuem uma predisposição para serem mais escravos que cidadãos $^{434}$, Bèze alega “dois testemunhos muito notáveis e dignos de serem escritos em letras de ouro, para ensinar a todos os Reis a comandar e aos povos a bem obedecer."435

O nosso autor seleciona dois exemplos que justificam suas ideias de controle dos governantes: um ainda remoto, no período datado do quarto concílio de Toledo em 644 (cujas

${ }^{431}$ A obra surge no início de 1576, quando ele ainda residia em Genebra, em 1574 já tinha anunciado sua intenção de redigir um tratado para refutar às teses de Maquiavel, em uma Representação. O Conselho de Genebra aprova a publicação de tal tratado em 21 de Outubro de 1575. RATHÉ, C. Edward. Introduction. In: GENTILLET, I. Discours sur les moyens de bien gouverner et maintenir en bonne paix un Royaume ou autre Principauté. Contre Nicolas Machiavel Floretin. Genève: Droz, 1968, p. 4.

${ }^{432}$ RATHÉ, C. Edward. Introduction. In: GENTILLET, I. Op. cit., p. 16.

${ }^{433}$ C. Edward Rathé pondera sobre os méritos do tratado Anti-Maquiavel, muitas vezes negligenciados pela recepção crítica: "O que é certo, é que seu Anti-Maquiavel continuou por muito tempo depois de sua morte, até a metade do XVII século, a exercer uma influência importante na polêmica anti-maquiavélica. Essa influência foi até mesmo exagerada pelos defensores de Maquiavel que criticavam em Gentillet seu espírito estreito, sua falta de probidade e seu fanatismo. Eles o acusam de ter feito de Maquiavel 'a cabra' emissária da São Bartolomeu. Maquiavel tornaria, por causa dele, o próprio símbolo da corrupção italiana que, através das ações de Catarina e seus cortesões, que destruíram as tradições políticas e os costumes da França. Esses argumentos possuem certamente uma dose de verdade, mas é limitar demais a significação de Anti-Maquiavel só o considerar unicamente uma obra de circunstância. Muitos são os que melhor conheceram o título que o conteúdo desse tratado, mas o próprio título já enfatiza: 'os meios de bem governar e manter em boa paz um reino'." RATHÉ, C. Edward. Introduction. In: GENTILLET, I. Op. cit., p. 9.

${ }^{434}$ BÈZE, Théodore de. Du Droit des Magistrats. Genève: Droz, 1970, p. 35. Em Aristóteles, defende-se a existência de uma categoria distinta da tirania propriamente dita entre certas monarquias bárbaras, pautadas num despotismo que possui maior origem na atitude de servidão intrínseca dos governados do que aos vícios dos governantes: "Encontramos exemplos de outra espécie de monarquia junto a alguns bárbaros. Os reis têm ali um poder que se aproxima do despotismo, mas é legítimo e hereditário. Tendo os bárbaros naturalmente a alma mais servil do que os gregos e os asiáticos, eles suportam mais do que os europeus, sem murmúrios, que sejam governados pelos senhores. É por isso que essas monarquias, embora despóticas, não deixam de ser estáveis e sólidas, fundadas que são na lei e transmissíveis de pai para filho. Pela mesma razão, sua guarda é real, e não tirânica, pois os reis são protegidos por cidadãos armados, ao passo que os déspotas recorrem aos estrangeiros. Aqueles governam de acordo com a lei e súditos de boa vontade; estes, pessoas que só obedecem contrafeitas. Aqueles são protegidos pelos cidadãos; estes, contra os cidadãos. São, portanto, dois tipos diferentes de monarquia.” ARISTÓTELES. A Política. São Paulo: Martins Fontes, 2006, p. 130.

435 BÈZE, Théodore de. Du Droit des Magistrats. Genève: Droz, 1970, p. 35. 
postulações foram reafirmadas no VI Concílio na mesma cidade), conforme as Crônicas de Segisberto, e outro mais contemporâneo à sua época, o juramento que vincula os governantes da Coroa Aragonesa. Ambos são extremamente vinculados ao direito feudal que, conforme vimos, para Bèze, é aplicável aos reinos e impérios.

Para Bèze, a cidade de Toledo, em seu quarto concílio no ano de 644, testemunha a assembleia de um sínodo, não apenas de eclesiásticos, mas também de outros elementos representativos dos povos espanhois componentes do Reino dos Godos.

O sucessor de Calvino, valendo-se das narrativas de Segisberto, reproduz em seu tratado as condições de vinculação entre governantes e governados avençadas pelo Concílio.

Em tal assembleia deliberou-se que a ninguém é dado o direito de ser sedicioso, tomando o reino para si, ou tramar a morte do rei. Morrendo o príncipe em paz, os "principais da nação" devem ser convocados juntamente com o estado eclesiástico, para que seja estabelecido "um sucessor do Reino por comum deliberação, a fim de que uma verdadeira concórdia seja por todos observada, e que ninguém empreenda dividir o país e a nação por ambição ou violência."436

Além de prever tal meio institucional de sucessão dos governantes, no concílio de Toledo ora referido ficaram consignadas maldições aos que atentassem contra os deveres de se acatar a preservação da dignidade real dos governantes, pois conforme fora deliberado:

[...] quem quer que seja dentre nós ou dos povos de Espanha por qualquer conjuração ou empreendimento terá violado esse juramento de fidelidade, que tem com a Pátria e a nação dos Godos, [...] ou que terá atentado à vida do Rei ou despojado de seu poder, ou por presunção de tirania terá usurpado a soberania real, [e que] sofra anátema diante da face de Deus e seus Anjos, e seja separado da Igreja católica que terá profanado por seu perjuro, e de toda Assembleia de Cristãos, ele e todos os seus cúmplices de sua impiedade, a fim de que aqueles que se encontram envolvidos nessa mesma culpa sejam castigados na mesma pena. ${ }^{437}$

Da mesma forma que tal concílio pune com o banimento da comunidade cristã e mesmo civil aquele que assim proceder contra seu governante, não concede destino diferente ao governante que tiranizar seu povo, mostrando o caráter sinalagmático das condições

\footnotetext{
${ }^{436}$ SEGISBERTO. Crônicas, apud BÈZE, Théodore de. Op. cit., p. 35

${ }^{437}$ Ibidem, p. 36.
} 
avençadas, uma vez que assim impõe aos reis e a seus sucessores: "Se alguém dentre eles, ao desprezo das leis, por soberba dominação, e se fazendo confiar de grandeza Real, em vilanias e atos maldosos ou por cupidez desmedida, usa de muito cruel poder sobre os povos, que ele sofra anátema da parte de Jesus Cristo nosso Senhor e seja separado de Deus, e julgado por ter ousado maldosamente fazer e transformar seu poder de Rei em destruição de seus sujeitos."438 Ainda da cidade de Toledo ${ }^{439}$, em seu VI Concílio, Bèze extrai um precedente de tolerância religiosa, algo tão demandado pelos huguenotes refugiados na Genebra de sua época e em certo sentido sob sua proteção, que consiste no decreto promulgado por esta assembleia proibindo "a caça aos judeus de todo Reino", e reafirma as condições já sedimentadas em concílio anterior para o exercício do poder dos reis: "É em vão que se faz o bem, se não da ordem que se persevera. E, no entanto, após o Rei chegar a seu poder, se ele falsear esta promessa, que ele esteja em execração Maran-atha diante a face de Deus eterno, e esteja no fogo eterno para sempre com todos aqueles que estarão envolvidos em sua culpa, sejam Eclesiásticos ou outros Cristãos."

O segundo exemplo de liberdade digno de alta consideração entre os bárbaros espanhois é extraído das práticas políticas dos Estados de Aragão, exemplo em que, em larga medida, Bèze recupera um tom de argumentação mais secular dentre os exemplos na Espanha, valendo-se de um paradigma puramente institucional da organização política de um emaranhado de nações, e não mais do concílio que tinha por objeto questões não puramente políticas.

Tais estados confederados têm como origem histórica o processo de união dinástica entre a Coroa de Aragão e o Condado de Barcelona em 1137, prosseguindo com a explusão dos árabes de Malhorca em 1229 e dos domínios de Valência em 1238, compondo desde então o núcleo central da dita Coroa, que ainda se expandiria em 1282 com a Sicília, em 1323-1324 com a Sardenha, e em 1442 incorporando o reino de Nápoles. ${ }^{441}$

Nessa confederação de Estados “(se eles ainda não mudaram)" ${ }^{\text {,42 }}$, Bèze destaca o cuidado com os compromissos de controle dos reis, que exige um juramento não apenas na

\footnotetext{
${ }^{438}$ SEGISBERTO. Crônicas, apud BÈZE, Théodore de. Op. cit., p. 36-37.

${ }^{439}$ Importa registrarmos a notoriedade e o simbolismo da cidade de Toledo, pela convivência religiosa pacífica entre as três religiões que, ao longo da Idade Média, conviveram na Península Ibérica, a islâmica, a judaica e a cristã.

${ }^{440}$ Decreto do VI Concílio de Toledo, apud BÈZE, Théodore de. Op. cit., p. 37.

${ }^{441}$ CALLICÓ, Jaume Sobrequés i. Historia de Cataluña. Barcelona: Editorial Base, 2007, p. 50-51.

${ }^{442}$ BÈZE, Théodore de. Du Droit des Magistrats. Genève: Droz, 1970, p. 38. Interpretamos essa passagem como uma sensibilidade da dinâmica do concerto dos reinos europeus por Bèze em sua época, uma vez que a unificação entre os estados da península ibérica, tão alardeada com o casamento dos reis católicos Fernando de Aragão e Isabel de Castilha em 1469 na cidade de Valladolid, em verdade em nada alterou a concepção dos
} 
coroação do rei, "mas também de três em três anos em seus Estados" colhido na organização política do conglomerado de nações pelo "representante da soberania", (atribuição conferida pelo próprio Bèze a tal agente político) que é chamado de Justiça de Aragão, que objetiva fazer o rei assumir o compromisso de distribuir a justiça, assim como receber o que lhe é devido, mas com a devida ressalva advertido pelo órgão que faz as vezes dos Estados: "Nós que valemos tanto como vós, e podemos mais que vós, vos elegemos Rei com estas e estas condições, entre vós e nós [há] um que manda mais que vós.",444

A Justiça de Aragão, uma das magistraturas mais importantes desses Estados, e peça chave para contenção da licenciosidade dos governantes nesses reinos ocidentais e a sudoeste da península ibérica, é descrita funcionalmente por T. N. Bisson como "oficial aragonês chamado a defender as prerrogativas do reino contra o rei."445 Apesar da importância do cargo para o regular funcionamento das instituições aragonesas, sua consolidação só se efetivou em 1348, quando, após uma grande crise e guerra civil entre os estados coligados, mesmo que Pedro IV, El ceremonioso, tenha sufocado os revoltosos, fazem-se várias concessões aos aragoneses (em sentido estrito) rebelados, como, por exemplo, concedendo "anistia (com algumas exceções), reconheceu o governante de Aragão a posição superior de cavalheiro, e definiu de forma mais precisa os poderes do Justicia, que desde essa

aragoneses (em sentido lato) o seu sentimento de pertecerem a uma confederação de povos, o que gerara conflitos constantes entre aragoneses e seu confederalismo e castelhanos (em sentido lato, que devem ser entendidos como castelhanos (sentido estrito), galegos, asturianos, leoneses, extremenhos, canários, andaluzes e mesmo os povos dos senhorios bascos) centralistas por definição. Jaume Sobrequés i Callicó, descreve que após a dita unificação dos reinos ibéricos, importa-se frisar que: "A Coroa de Aragão e o Reino de Castilha conservaram suas leis, seus dirigentes, suas instituições de governo [...]. Entre Castilha e a Coroa Aragonesa havia fronteiras políticas, militares e econômicas bem definidas, e uma moeda diferente. E mais ainda: os catalães [e demais aragoneses] eram considerados estrangeiros para todos os efeitos em Castilha, e os castelhanos o eram [também] em Catalunha e em toda a Coroa de Aragão", as tensões entre esses dois blocos de reinos e suas concepções políticas de organizar o poder (confederalismo aragonês versus centralização castelhana) terá fim apenas com a verdadeira centralização política da Monarquía hispânica com a derrota da Coroa de Aragão em 1714 na Guerra de Sucessão (porém, ainda hoje as vozes do nacionalismo catalão invocam as liberdades, dentre outros fatores, da Coroa Aragonesa e seu confederalismo para legitimarem um estado nacional catalão soberano). (CALLICÓ, Jaume Sobrequés i. Historia de Cataluña. Barcelona: Editorial Base, 2007, p. 50-51). Para muitos historiadores, a própria exclusão dos súditos da Coroa Aragonesa do processo de colonização da América se deve, além das justificativas clássicas, pelo fato de ter sido Isabel de Castilha quem patrocinara Colombo, o interesse dos aragoneses pelo comércio mediterrâneo, somaria-se aos antecedentes o temor dos súditos da Coroa Aragonesa de trazer para os domínios coloniais suas ideias contratuais da vida política, absolutamente incompatíveis com o Pacto Colonial, conforme explicam Sebastián Quesada e Ramón Tamanes: "os súditos da Coroa de Aragão ficaram excluídos dos novos territórios, que eram considerados exclusivamente castelhanos. Em verdade, como admitem muitos historiadores, se desconhece o peso que teve naquela exclusão o temor da Coroa de que os catalanoaragoneses exportassem a América seu conceito de poder como resultado do pacto." QUESADA, Sebastián; TAMAMES, Ramón. Imágenes de España. Madrid: Edelsa, 2001, p.57.

${ }^{443}$ BEZZE, Théodore de. Du Droit des Magistrats. Genève: Droz, 1970, p. 38.

${ }^{444}$ Advertência dos Estados Aragoneses ao Rei, apud BÈZE, Théodore de. Op. cit., p. 38.

445 BISSON, T. N. The Medieval Crown of Aragon. Oxford: University Press, 1986, p. 194. 
época em diante passa a ser efetivamente o defensor das liberdades dos aragoneses"446, chegando a ser o mais importante oficial no período de apogeu dessa confederação hispânica durante a Baixa Idade Média. ${ }^{447}$

Esmiunçando melhor a real natureza desse elemento na vida política aragonesa, Geisey mostra que El Justicia "não era o pináculo da hierarquia do poder real, mas uma unidade autônoma" ${ }^{\text {"48 }}$. Em regra, seus poderes eram equiparáveis aos de qualquer juiz de um reino medieval, que em certas circunstâncias era apto a "afirmar sua autoridade excluindo todas as demais". Porém, no século XV, o poder extraordinário dessa magistratura se consolida por meio de dois institutos jurídicos, que conferiam um exercício liberatório do poder real sobre os súditos, permitindo assim o crescimento do mito em torno de seu cargo. Tais institutos são: manifestación e firmas de derecho ${ }^{449}$.

O primeiro desses institutos, que continha elementos do habeas corpus inglês e do due process of Law, dava a prerrogativa ao Justicia aforar para sua própria jurisdição qualquer indivíduo detido por qualquer autoridade judicial ou real (que por sua vez, em regra, deviam obediência aos reis), com o escopo de assegurar que a acusação fosse justa ${ }^{450}$.

Pelas firmas, o Justicia podia apreciar pedidos de qualquer súdito com o pleito de garantir suas vidas ou propriedade de julgamentos contrários às leis.

Para Ralph Geisey, a inserção do juramento dos Estados Aragoneses, na obra de Bèze, muito provavelmente se deve à influência direta de reformadores espanhois refugiados, que buscavam em Genebra, que tinha à frente nosso autor como líder do movimento calvinista, a possibilidade de traduzir tratados de reformadores para os espanhois, imprimi-los e constrabandeá-los para a Espanha ${ }^{451}$. Apesar desse juramento figurar já na obra de Hotman publicada anteriormente à de Bèze e à posteriormente reproduzida na Vindiciae contra tyrannos, claramente extraído da edição latina da obra de Bèze, Geisey afirma ser um erro imaginar que Bèze teria obtido tal informação de Franco-Gallia, até pelas evidências dos arquivos que apontam as obras terem sido escritas praticamente ao mesmo tempo e com o

\footnotetext{
${ }^{446}$ BISSON, T. N. The Medieval Crown of Aragon. Oxford: University Press, 1986, p. 108-109.

${ }^{447}$ GIESEY, Ralph A. If Not, Not, the oath of the aragonese and the legendary laws of sobrarbe. Priceton: Priceton University Press, 1968, p. 67.

448 Ibidem, p. 67.

${ }^{449}$ Ibidem, p. 67.

${ }^{450}$ Ibidem, p. 67.

${ }^{451}$ Ibidem, p. 22.
} 
conhecimento recíproco da obra de um e de outro ${ }^{452}$; tal citação do juramento, portanto, se deve à referida convivência com os reformadores vindos da fronteira pirinaica.

Antes de adentrar no problema da França de seu tempo, Bèze faz um breve comentário sobre "a mais ilustre das Assembleias de Príncipes que existe no mundo", que possui tanto poder de eleger como para depor seu imperador se necessário.

Como prova dessas faculdades da Assembleia dos sete eleitores do Santo Império, Bèze cita os exemplos dos imperadores depostos por ela: Adolfo, no ano $1296^{453}$, e o imperador Wenceslau (Wenzel), no ano de 1400.

O último exemplo, conforme visto anteriormente, já figurava no corpo argumentativo de Filipe de Hesse e seus juristas, contra as manobras de Carlos V, à época da Dieta de Speyer, em $1529 .{ }^{454}$

Além do mais, pautando-se no Speculum Saxonicum, afirma que os reis germânicos também estavam obrigados pelo mesmo juramento, já que "quando o Rei se elege, é necessário que ele jure e preste fidelidade e homenagem ao Império, e que ele impulsionará e ajudará com suas forças a Justiça, impedindo com todo seu poder todos os insultos, e manterá o Império em seus direitos com todo seu saber e poder." 455

Após ter sistematizado exemplos institucionais de oposição lícita, ou mesmo mecanismos prévios com finalidade de conter a licenciosidade dos tiranos, apontando para uma das características mais fundamentais do direito de resistência que, na sua acepção, gozaria de uma universalidade intrínseca, o sucessor de Calvino arremata a discussão com o exemplo que talvez mais o interessaria: a previsão dos mesmos mecanismos institucionalizados e ainda indubitavelmente válidos em sua França natal, como meios aptos para sanar a tirania sofrida pelo partido protestestante perseguido pelos Valois.

\footnotetext{
${ }^{452}$ GIESEY, Ralph A. If Not, Not, the oath of the aragonese and the legendary laws of sobrarbe. Priceton: Priceton University Press, 1968, p. 21-22. Geisey assim descreve a improbabilidade de Bèze ter se valido da citação de Hotman quanto ao juramento, assim como as circunstâncias irmanadas do surgimento das duas obras: "Seria um erro admitir que Bèze deva ter extraído o Juramento de Hotman só pelo motivo de seu tratado ter sido publicado um ano depois. As evidências dos arquivos revelam que Bèze e Hotman terminaram seus tratados em Julho de 1573, e cada teve um profundo conhecimento do trabalho do outro. Bèze, em verdade, tentou persuadir o Conselho de Genebra para permitir a publicação de Francogallia de Hotman, e Hotman devolveu a honra, tentando imprimir o tratado do amigo (que o Conselho da Cidade de Genebra julgara muito radical) em outra cidade." GIESEY, Ralph A. Op. cit., p. 21.

${ }^{453}$ R. Kingdon aponta para uma imprecisão na data, pois para o comentador ora referido, deu-se no ano de 1298. KINGDON, Robert M. Nota 1. In: BÈZE, Théodore de. Du Droit des Magistrats. Genève: Droz, 1970, p. 38.

${ }^{454}$ SKINNER, Quentin. As fundações do pensamento político. São Paulo: Cia das Letras, 2000, p. 471.

455 BÈZE, Théodore de. Du Droit des Magistrats. Genève: Droz, 1970, p. 38.
} 
Porém, apesar de haver uma justa expectativa do leitor do tratado em análise em encontrar uma referência direta sobre os massacres da noite de São Bartolomeu ${ }^{456}$, Bèze mantém silêncio quanto ao episódio, além de silenciar também quanto ao conteúdo de vários aspectos da história constitucional francesa, descritos em Franco-Gallia. Um silêncio que poderíamos chamar de eloquente (caso isso não seja uma contradição em termos). No caso de Hotman, o silêncio se justificaria, segundo Giesey (e a nosso ver, tal análise seria perfeitamente aplicável a Bèze), para causar um máximo efeito ao leitor. Assim, usa-se "da melhor recomendação pedagógica, ao permitir o leitor fazer sua própria inferência [...]" sobre os dramas sofridos pelo partido protestante à época de Bèze. ${ }^{457}$

Seguindo de perto a investigação histórica feita por Hotman, vê-se que ele já assevera que César, em sua narrativa do livro V de suas proezas pela Gália (De bello gallico $^{458}$, já mostrava a sujeição dos governantes aos Estados dos povos da Gália. ${ }^{459}$ Posteriormente esclarece que a união de gauleses e francos sob o nome de franceses perseverou em tais práticas de liberdade.

Nosso autor, valendo-se dos estudos de Hotman apresentados no capítulo VI (com sutis diferenças), afirma categoricamente a supremacia do elemento eletivo para a sagração dos reis francos em detrimento do direito sucessivo imediato, uma vez que "os Francos, ainda que tenham escolhido seus Reis primeirammente da linhagem dos Merovíngios, após a posteridade de Carlos Magno, e finalmente os descendentes de Hugo Capeto, no entanto adestraram sua monarquia no início [de tal forma], que seus Reis não reinavam por exclusividade do direito sucessivo, assim sendo eleitos pelo consentimento dos Estados do Reino." 460

Recorrendo à autoridade de Aimoin de Fleuri, cronista francês (Historia Francorum), Théodore de Bèze reproduz no tratado o juramento feito pelo rei Carlos, $o$ Calvo, rei dos francos ocidentais (com o desmebramento do Império Carolíngeo), considerado pela historiografia clássica como detentor dos domínios territoriais que iriam compor o território da França atual, restando inconteste o caráter de condicionalidade do juramento dos

\footnotetext{
${ }^{456}$ Registra-se que, quando Bèze discute o exemplo francês, talvez essa justa expectativa de um leitor do tratado seja maior, já que nosso autor não se furta a comentar vários exemplos de seu tempo ou muito próximo a ele como: Inglaterra, Escócia, Dinamarca, Suécia, estados aragoneses etc.

457 GIESEY, R. E. When and Why Hotman wrote the Francogallia. In: Bibliothèque d Humanisme et Renaissance, n. XXIX, 1967, p. 583.

${ }^{458}$ KINGDON, Robert M. Nota 1. In: BÈZE, Théodore de. Op. cit., p. 39.

${ }^{459}$ BÈZE, Théodore de. Op. cit., p. 39.

${ }^{460}$ Ibidem, p. 39.
} 
reis aos Estados. Além do mais, Bèze rememora o fato de os filhos do dito rei terem sido preteridos no momento da sucessão real, sendo eleito como rei Eudes ${ }^{461}$.

Nos termos do registro do abade cronista francês Amoin Fleuri, é o juramento:

Já que vós me elegestes para vos reger e governar, sabeis que minha deliberação é, por meio da ajuda de Deus, manter a honra e serviço de Deus e das santas igrejas e igualmente honrar, cuidar e honradamente manter cada um de vós em seu lugar de honra e em sua pessoa, tanto quanto eu saberei e poderei fazer e manter a cada um seu grau, direito e justiça, tanto nos negócios eclesiásticos, quanto naqueles deste século, no qual a honra atribuída ao Rei com toda devida obediência e ajuda para manter e conservar o Reino que me foi comissionado de Deus, me seja rendida por cada um de vós segundo o seu grau, dignidade e possibilidade, como vossos ancestrais justamente, lealmente e racionalmente prometeram. ${ }^{462}$

Do texto do compromisso assumido por Carlos, o Calvo, extraem-se os deveres que, para Bèze, são tão caros a um governante e convenientes para a causa abraçada por nosso autor: a obrigação de zelo e proteção da verdadeira fé, como também a garantia de inviolabilidade das prerrogativas dos ocupantes de cargos de proeminência no reino da França que compunham os Estados Gerais.

Ainda sobre a sucessão no Reino da França, explica, num tom em muito semelhante ao de Hotman, que: "quanto à autoridade dos mesmos Estados de estabelecer e depor os principais oficiais da Coroa, ou pelo menos ter o olho naquilo que seus Reis fazem, impondo parâmetros e outros negócios principais do governo na paz e na guerra, as antigas e autênticas histórias a retratam fielmente, e demonstram manifestamente o despudor dos bajuladores que se engrandessem com a destruição de um tal e tão bem ordenado Reino."463

Em seu tempo, Bèze reconhece a degeneração do Reino da França, que abandona as práticas garantidoras da liberdade realizadas pelos Estados Gerais, não mais convocandoos, ficando sequestradas as principais decisões do Reino nas mãos de "certos personagens que só olham para a sua comodidade e segurança". Ocorreu uma série de práticas espúrias aos olhos das boas tradições públicas: a sucessão não se dá por eleição, mas "o mais próximo do

${ }^{461}$ BÈZZ, Théodore de. Du Droit des Magistrats. Genève: Droz, 1970, p. 41.

${ }^{462}$ Juramento de Carlos o Calvo. In: FLEURI, Amoin. Historia Francorum apud BÈZE, Théodore de. Op. cit., p. 40.

${ }^{463}$ BÈZZE, Théodore de. Du Droit des Magistrats. Genève: Droz, 1970, 41. 
sangue real sucede", impostos, empréstimos, a guerra e a paz são feitas e desfeitas, dignidades e oficiliadades são comercializadas, concedidas ou retiradas. De tal modo que estas práticas devem ser consideradas como "totalmente contrárias à maneira de se fazer dos [nossos] bons Ancestrais, e frontalmente repugnantes às leis postas como fundamento da Monarquia Francesa." 464

Como um arremate de sua argumentação de defesa sobre a importância e imprescindibilidade dos Estados Gerais como instância idônea para decidir os rumos das grandes questões da França, conforme mencionado anteriormente, ainda que Bèze não faça referência direta aos conturbados tempos de sua terra natal (nomeando reis, regentes ou éditos iníquos), deixa indiretamente, a título sugestivo, talvez um apelo à convocação aos Estados como remédio para as circunstâncias, pois apresenta um elemento sobre a vida política francesa que é um desafio.

Trata-se do desafio jurídico de qualquer um que tenha a ousadia de afirmar que as prerrogativas dos Estados Gerais não existem mais:

eu deixo a disputa a todos os Jurisconsultos de boa ciência e consciência, se alguma prescrição [das prerrogativas dos Estados Gerais] pelo decurso do tempo [...] pode ter tido lugar por direito humano e divino. Mas [o fato é] que ainda os Reis hoje fazem [em] sua sagração (que deve ser impresso e conhecido por todo o mundo) e que os Reis são obrigados em seu advento de confirmar os privilégios das cidades e dos Oficiais do Reino (salvo abuso que se cometa), e que os Reis sendo menores, os Estados advertem quem terá a administração, sendo portadores da antiga autoridade dos Estados, que fenece pouco a pouco. ${ }^{465}$

Como exemplos mais próximos da época de atuação plenamente vigorosa dos Estados, Bèze relembra a rescisão do testamento de Charles V, o sábio, por estes, no ano de 1380. Sobre o ano de 1467, alerta para o fato de Luís XI, após ter causado vários transtornos ao Reino, tranformando a Monarquia da França em Tirania, tenha recebido como emenda da assembleia dos Estados, ocorrida em Tours, uma curatela de "trinta e seis pessoas, pelas quais ele teria que ser governado e conduzido." ${ }^{466}$

\footnotetext{
${ }^{464}$ BÈZE, Théodore de. Du Droit des Magistrats. Genève: Droz, 1970, p. 41.

${ }^{465}$ Ibidem, p 41-42.

${ }^{466}$ Ibidem, p. 42.
} 
Por fim, o último exemplo, muito memorável, seria o de Charles VII que, ainda aspirante ao trono, fora muito mal aconselhado, contrariando um tratado de paz assumido com o Duque da Borgonha, o faz ser massacrado diante seus olhos, chafurdando a França em conflitos civis que "custaram um milhão de almas". Charles foi sancionado com a deserdação de seu pai, viu seu inimigo ser coroado em Paris e "ser mais Rei de Bourges do que da França”. Após tantos distúrbios, compra-se a paz pelo tratado de Arras, no qual é inserida uma cláusula que deixa expressa a quitação de toda e qualquer sujeição ao rei Charles (da parte dos súditos da Borgonha), no caso dele desobedecer outra vez o novo acordo. ${ }^{467}$

No exemplo acima referido, percebe-se uma reafirmação do pacta sunt servanda, mesmo em compromissos que não são da suprema importância, como os assumidos no momento da coroação dos reis, mas que devem ser estritamente observados, sob pena do "Reino não encontrar repouso." Esta passagem, seguindo a ideia interpretativa de Geisey anteriormente referida, parace-nos sugestiva de uma exortação indireta do dever dos Conselheiros dos Reis ou Regentes da França a bem aconselharem aos Príncipes Herdeiros, ou aos Reis propriamente, a observarem seus compromissos, como os éditos de tolerância religiosa, que eram constantemente desrespeitados pelos governantes da França, à época de Bèze.

Dentre os éditos de tolerância, devemos destacar o de janeiro de 1562, que seria uma arma legal para os protestantes se esquivarem de serem chamados de sediciosos, pois esse édito autorizava, ainda que com restrições, o culto da nova fé, e, segundo Joseph Lecler, tal édito, juntamente com o Colóquio de Poissy que o precedeu, "marcariam sucessivamente o fim das tentativas de conciliação religiosa e a inauguração, ainda que precária, mas real e legal, da tolerância civil dos reformados." ${ }^{468}$

\subsection{Os objetos de tutela da proteção magisterial: "a liberdade de consciência religiosa", a propriedade e o regular funcionamento das instituições da República.}

Os objetos de tutela de que estão encarregados os magistrados para proteção de seus jurisdicionados, segundo Bèze, seriam: "a liberdade de consciência religiosa", a propriedade e o regular funcionamento das instituições da República (especialmente o não impedimento da convocação dos Estados-Gerais.). A privação do exercício de tais direitos

\footnotetext{
${ }^{467}$ BÈZE, Théodore de. Du Droit des Magistrats. Genève: Droz, 1970, p. 43.

${ }^{468}$ LECLER, Joseph. Histoire de la tolérance au siècle de la Réforme. Paris: Albin Michel, 1994, p. 456.
} 
constituiria manifestação de tirania por parte dos governantes, ainda que a violação de certos direitos ensejem uma resposta mais prudente do que a de outros.

Sem a menor sombra de dúvida, o "livre exercício da consciência religiosa" constitui-se como direito primordial para Bèze, e os demais direitos, em última análise, podem ser considerados, em certa medida, satélites do mesmo, que se prestam a auxiliar o seu exercício, o que sugere um distanciamento da tradição clássica, já que a tirania no pensamento da Reforma seria a atuação num campo que extrapola a ação legítima do governante.

Para Jonh Witte Jr., "o primeiro e mais essencial dos direitos dos primeiros Calvinistas eram direitos religiososos, direitos do crente individualmente gozar de liberdade de consciência e livre exercício da religião, e os direitos do grupo religioso gozar de liberdade de culto e autonomia." 469

A questão da "liberdade de consciência religiosa", que em verdade se trataria mais do livre exercício da verdadeira fé, segundo os ditames reformados, do que qualquer outra coisa ocupa o último capítulo do tratado, talvez justamente por figurar o bem imaterial que mais necessita de tutela contra os desmandos dos governantes nas circunstâncias em que viviam Bèze e seus corrileginários, além de se apresentar como um arremate de todo o tratado.

Nesse tópico, Bèze se propõe a responder o que deve ser feito caso advenha uma tirania que se exerça sobre a liberdade religiosa, à luz de tudo o que havia discorrido até então no tratado. A questão, segundo o reformador, deve ser norteada por duas evidências: uma primeira, de que a religião pertence ao domínio da consciência e, como tal, não deve ser imposta a força ou fundar-se pelas armas; a segunda, de que no debate da questão devem-se considerar também as peculiaridades do mundo espiritual e desse mundo ${ }^{470}$. Oportunidade em que, a nosso ver, Bèze faz uma defesa entusiasta da possibilidade de se advir uma supremacia do poder civil sobre o religioso, caso as circunstâncias exigirem a libertação do povo da idolatria, além de elogiar atitudes de governantes ao longo da história claramente de cunho cesaropapista, ou ainda permitir não ao povo mas às autoridades, suficientemente autorizadas pelas leis, resistir com armas se for preciso.

\footnotetext{
${ }^{469}$ WITTE Jr., John. The Reformation of Rights: Law, religion, and human rights in early modern Calvinism. Cambridge: Cambridge University Press, 2007, p. 2. Ainda para o mesmo comentador, os primeiros calvinistas: "viam esses direitos individuais e de grupo como ao mesmo tempo natural e positivo, pessoal e civil no feitio. Para eles, esses direitos estavam enraizados na ordem natural e na natureza humana, mas eles tiveram de ser formulados e reivindicados como direitos positivados e lei estatal.” WITTE Jr., John. Op.cit., p. 35.

${ }^{470}$ BÈZE, Théodore de. Du Droit des Magistrats. Genève: Droz, 1970, p. 63.
} 
Quanto à primeira evidência, nosso autor exorta que a verdadeira religião, por se tratar de um domínio da consciência, apresenta um maior avanço por meios pacíficos e apropriados à sua disseminação como a "predicação da Palavra de Deus, [assim como] por orações e paciência" ${ }^{471}$. Desse modo, deve um Príncipe zeloso por seu povo, ao objetivar salvá-lo da idolatria ou das superstições, "instruir por bons e vivos argumentos"; por outro lado, os súditos devem se render à razão e à verdade. No caso de uma negativa dessa natural rendição espiritual esperada por Bèze, ele aponta como solução aos obstinados refratários à adesão da verdadeira fé que "o Princípe deve estebelecer e manter bons Éditos contra aqueles que por mera obstinação quererão resistir ao estabelecimento da verdadeira Religião, como nós vemos em nossa época ter sido praticado na Inglaterra, Dinamarca, Suécia, Escócia, uma boa parte da Alemanha, e da Suíça, contra o Papado, os Anabatistas, e outros heréticos." ${ }^{472}$

Apesar de Bèze ter iniciado a argumentação de forma a sugerir uma plena liberdade de consciência religiosa, arremata a argumentação com uma marca de intolerância, pois conforme explica Josep Lecler com base na passagem acima referida, Th. de Bèze não teria uma posição mais liberal do que a da obra Da punição dos hereges pelo magistrado civil, de 1554; não obstante nosso autor admitir na obra de 1574 "o direito dos corpos da nação de se revoltar contra um poder tirânico, $[. .$.$] no interior desse sistema, a pessoa privada$ não gozaria dessa prevista liberdade religiosa, [de tal forma que] a sanior pars [...] resta sempre o direito de castigar os heréticos e impor à nação a unidade religiosa."473

Quanto às particularidades inerentes às coisas do Reino desse mundo e do Reino espiritual que devem ser consideradas para enfrentar a questão, Bèze esclarece a perfeita compatibilidade entre o fato de que, ao longo da história do Cristianismo, vários cristãos, como os apóstolos, os antigos mártires e o próprio Jesus Cristo ${ }^{474}$, padeceram os horrores de tiranias até as últimas consequências, com o perecimento da própria vida, porém valeram-se apenas dos meios adequados do mundo espiritual, ou seja, "orações e paciência", inclusive por estrito respeito às suas vocações de particulares. ${ }^{475}$ Porém afirma que seria erro e mesmo absurdo, considerar que as "defesas próprias aos negócios desse mundo (como são a Justiça e as armas)" sejam "não apenas diferentes com relação às defesas espirituais, mas também

\footnotetext{
${ }^{471}$ BÈZE, Théodore de. Du Droit des Magistrats. Genève: Droz, 1970, p. 63.

472 Ibidem, p. 66.

${ }^{473}$ LECLER, Joseph. Histoire de la tolérance au siècle de la Réforme. Paris: Albin Michel, 1994, p. 333.

${ }^{474}$ Bèze esclarece que apesar de Jesus Cristo "ele mesmo, ao qual toda autoridade, toda força e poder pertencia", deve ser considerado em termos de análise nesse tópico como um particular que respeitara sua vocação como tal. BÈZE, Théodore de. Op. cit., p. 63 e 67.

${ }^{475}$ Percebe-se que, para solução da questão, Bèze recorre a noções fundamentais da teologia de Calvino, conforme visto anteriormente, a de vocação e o "princípio correto no uso das coisas da presente vida", extraídas do capítulo X, do Livro III da Instituição da Religião Cristã.
} 
contrárias e tão repulsivas [uma da outra], que em matéria de Religião elas não possam ter lugar."476

Nessa ocasião, mesmo que ao longo do tratado Bèze tenha se valido amplamente de fontes seculares para legitimar o exercício lícito de resistência política, e ainda que em certo sentido tenha recorrido à autoridade da história sagrada, após dessacralizá-la, ou ter buscado compatibilizar o ensinamento pagão com o ensinamento da verdade revelada, o autor não obstante persevere neste esforço de secularização quanto aos meios aptos para o exercício do direito de resistência, expõe sua opinião sobre a finalidade da vida civil de modo divergente dos Filósofos Pagãos, pois se para estes últimos "o verdadeiro objetivo da vida política bem estruturada" seria a tranquilidade nessa vida, Bèze despoja-se de sua pena de humanista e jurista e reassume a do teólogo, ao dizer que o verdadeiro fim da vida política é "a glória de Deus" "477.

Devido a essa finalidade, Bèze clama aos magistrados para exercerem seus meios terrenos, ou seja, as armas e a Justiça, os quais são perfeitamente compatíveis com suas vocações de pessoas públicas "contra aqueles que de outra forma não poderiam ser impedidos." 478

Ainda referente ao binômio de vocação e suas respectivas habilitações para o uso de meios de resistência às tiranias, Bèze reafirma a validade de suas teses quanto à eventual alegação de a suposta incompatibilidade entre as narrativas cristãs descritas nos martiriológicos que relatam "pessoas de Estado e mesmo legiões inteiras com seus Chefes" padecerem o martírio, ainda que na ocasião existissem Éditos anteriormente favoráveis aos cristãos, principalmente sob o império de Diocleciano e Juliano.

Bèze responde a esta eventual contestação que faria minar o núcleo de sua argumentação do direito de resistência ativa lícita entregue a magistrados, conforme nosso autor constantemente proclama ser nada sediciosa, preenchendo a pena com a tinta do jurista, da seguinte forma: "ainda que alguns Imperadores que precederam Diocleciano, como Adriano, Antonino e Alexandre tivessem abrandado as perseguições, não tinham eles permitido o público exercício da Religião Cristã." ${ }^{\text {"79 }}$. Ou seja, tais magistrados padeceram o martírio por lhes faltar autorização legal suficiente para proceder à resistência.

\footnotetext{
${ }^{476}$ BÈZZ, Théodore de. Du Droit des Magistrats. Genève: Droz, 1970, p. 64.

${ }^{477}$ Ibidem, p. 64.

${ }^{478}$ Ibidem, 1970, p. 65.

${ }^{479}$ Ibidem, p. 67.
} 
Isto posto, resta a Bèze elevar ao status de mártir em pé de igualdade não apenas os que procederam com paciência e orações e pereceram pacificamente em mãos tiranas, mas também aquelas autoridades públicas "suficientemente autorizados pelas leis" e seus subordinados que desembainharam a espada "para a defesa da verdadeira Religião" 480 .

Quanto ao direito de propriedade, ainda que Bèze tenha sido um árduo defensor e negociador dos interesses financeiros dos huguenotes refugiados em Genebra junto ao Conselho de Genebra e à Coroa Francesa, na tentativa de ao menos obter que os exilados tivessem a permissão de retornar à França para venderem suas propriedades ou negociar algum outro arranjo político com o fim de obterem seus rendimentos ${ }^{481}$, Bèze apenas trata das questões dos "tributos e impostos iníquos" no capítulo VIII, e com certo desdém para com a temática, talvez por entender tal direito como inferior, numa escala de importância a outros, como o de liberdade da consciência religiosa, ou o do regular funcionamento das instituições de uma República.Para a solução do problema, nosso autor responde de forma sintética e genérica que "aqueles que têm autoridade, como nós dissemos, podem e devem colocar ordem segundo as leis do Reino."

À margem do referido tópico do tratado, Bèze assevera em teor de cautela: "Todo Príncipe que comete excessos não é ainda Tirano", ou seja, a opressão advinda de questões fiscais e outras assemelháveis, para fins de custeio da prodigalidade de um governante, ou outros vícios menores, não justificaria o recurso a vias de fato. Como reforço de sua tese, evoca uma sentença do dramaturgo e poeta romano Terêncio, extraída da obra $O$ Eunuco $^{483}$, que diz: "ainda que ela tenha sido pronunciada por um Pagão" a julga notável: "os sábios experimentam todas as coisas antes de chegarem às armas."

A terceira forma de expressão de um governo tirânico, para o nosso autor, seria a vedação do funcionamento das instituições da República que se prestam ao que permite a resistência.

Nessa questão, sobretudo tratada no capítulo VII, intitulada Como se deve conduzir contra a Tirania que impede a Assembleia dos Estados, nosso autor aponta principalmente os Estados Gerais como o mecanismo mais idôneo para solução da problemática. Porém, se a tirania for de tal monta a ponto de obstruir o remédio dos Estados, inclusive por "conivência, temor ou maldade" da maioria de seus principais componentes,

\footnotetext{
${ }^{480}$ BÈZE, Théodore de. Du Droit des Magistrats. Genève: Droz, 1970, p. 67.

${ }^{481}$ KINGDON, R. Introduction. In: BÈZE, Théodore de. Du Droit des Magistrats. Genève: Droz, 1970, p. XVI.

482 BÈZE, Théodore de. Du Droit des Magistrats. Genève: Droz, 1970, p. 61.

${ }^{483}$ Ibidem, p. 61.
} 
Bèze diz que nada pode um particular, caso não tenha autorização pelo menos da "parte mais sã" componente da Assembleia que não se acanhou em seus deveres ou dos magistrados subalternos, cabendo a esses mesmos particulares, vítimas da tirania, "arrependimento [de seus pecados] e paciência com orações" 484 . Tal solução em muito guarda semelhança com a dada pelos conciliaristas que em seus escritos sobre o caso de um papa impedir a reunião de um concílio, conforme visto.

Apesar do quadro difícil das circunstâncias configuradas hipoteticamente por Bèze, ele assevera, porém, que não haveria nenhum impedimento desses mesmos particulares exigirem uma reação dos magistrados inferiores, no sentido de "se unirem e apressar a assembleia dos Estados, mas mantendo [a ordem das coisas] tanto quanto se possa e se deva fazer contra uma tirania manifesta." ${ }^{485}$. Com essas afirmações, nosso autor não reconhece uma faculdade exclusiva dos Estados Gerais de solucionar o problema da tirania manifesta como se dá em Hotman, e confere aos magistrados inferiores os mecanismos (ainda que mais limitados) de controle.

Tal legitimidade conferida aos magistrados se dá na medida em que "o dever deles é o de guardar as boas leis, das quais eles juraram a observação, mesmo contrariando a todos, segundo a porção do estado público que lhes é comissionada, e geralmente de impedir que as boas leis e condições, sobre as quais o estado público está fundado, não sejam falseadas por alguma força vinda de dentro ou de fora."

Ainda sobre a temática da necessidade de se preservar os mecanismos institucionais de uma República como o meio idôneo de se rebelar contra uma tirania, Bèze censura na Antiguidade o povo israelita de ter se rebelado contra Roboão, um príncipe que promovia extorções, assim como o assassinato de Aduram, um dos seus magistrados delegado das funções tributárias, "chefe da corveia" 487 . Tal evento "foi uma pura revolta e rebelião ilegítima, quanto aos caminhos que eles [os revoltosos] tomaram, em vez de pela via do direito e da força bem regrada, eles poderiam e deveriam se opor à Tirania, porque as vezes ocorre de se fazer coisa justa injustamente" ${ }^{488}$. Ou seja, Bèze entende ser fundamental não apenas o conteúdo da atitude contrária à tirania, mas também a adequação dos meios.

Além do mais, quanto à questão de se valorizar os mecanismos institucionais de solução de conflitos numa República, em situações de menor complexidade quando

\footnotetext{
${ }^{484}$ BÈZE, Théodore de. Du Droit des Magistrats. Genève: Droz, 1970, p. 53.

${ }^{485}$ Ibidem, p. 53.

${ }^{486}$ Ibidem, p. 55.

${ }^{487}$ I Reis, 12: 18. In: Bíblia de Jerusalém. São Paulo: Paulus, 2006, p. 488-489.

${ }^{488}$ BÈZE, Théodore de. Du Droit des Magistrats. Genève: Droz, 1970, p. 59.
} 
comparada a de um governante se tornar tirano obstinado e merecedor de sua destituição, Bèze enfatiza o dever de um bom súdito não sedicioso de se valer dos mecanismos ordinários de exercício de poder para solucionar problemas entre tal súdito e magistrados em um nível hierárquico inferior ao do supremo magistrado, sem jamais recorrer a uma solução pela via da auto-tutela.

Tal exortação encontra guarida no item IV do tratado, que dispõe sobre a hipótese de a iniquidade de magistrados dirigir-se ao particular que em boa consciência se recusa "a executar uma coisa maldosa" exigida por aquele.

Bèze diz que quando "o magistrado que comete erros em relação ao seu súdito e está sob [a sujeição hierárquica] de outro soberano, a ofensa pode ter recursos a seu soberano, como as leis os trazem." ${ }^{489}$. Cita como exemplo a narrativa bíblica da apelação de São Paulo à César para corrigir a decisão do erro do governador da Judeia, Festo, que se posicionava hierarquicamente abaixo de César.

Uma segunda hipótese que se resolve por um princípio de hierarquia, dentro do pensamento político beziano, consiste no fato de que se dois magistrados inferiores se colocarem em conflito, aquele que perpetra a violência contra um segundo, contrariando a "vontade de toda notória do soberano", é lícito a este último ultrajado "após ter tentado todos os outros meios mais suaves, de se munir de leis e repulsar uma força injusta por uma justa defesa" ${ }^{490}$, recorrendo ao soberano.

Entendemos serem os direitos acima mencionados facilmente identificáveis com aqueles surgidos no século XVII que seriam denominados de primeira geração, o que nos leva à conclusão de certa antecipação teórica dessas ideias de Bèze e dos demais calvinistas continentais. Além do mais, para alguns comentadores, haveria uma ligação direta entre as práticas tidas como revolucionárias da Inglaterra do século XVII e a norte-americana do XVIII $^{491}$, que classicamente são apontadas como instituidoras desta geração de direitos.

Numa visão, a nosso ver extremamente generosa com essa literatura política, Witte Jr. concebe as circunstâncias vividas pelos protestantes franceses refugiados em Genebra como um laboratório com elementos para construção das três gerações de direitos consagradas nos manuais contemporâneos de direito constitucional.

\footnotetext{
${ }^{489}$ BÈZE, Théodore de. Du Droit des Magistrats. Genève: Droz, 1970, p. 7.

${ }^{490}$ Ibidem, p. 7-8.

${ }^{491}$ BERMAN, Harold J. Law and Revolution, The Formation of the Western Legal Tradition. v. II, Cambridge, Massachusetts \& London, England: Harvard University Press, 1983, p. 9; WITTE Jr., John. The Reformation of Rights: Law, religion, and human rights in early modern Calvinism.Cambridge: Cambridge University Press, 2007, p. 31.
} 
Além daqueles direitos de primeira geração que versam sobre a oponibilidade dos direitos do súdito (e posteriormente cidadão) em relação aos governantes, o referido autor descreve práticas e pregações cujo conteúdo muito se assemelha aos direitos de segunda geração (originados apenas no período entre guerras do século XX), pois as circunstâncias vividas pelos refugiados em Genebra exigiram fornecimento de educação infantil, provisões e emprego para necessitados, enfim uma rede de assistência social, e, por fim, direitos de terceira geração (que seriam consagrados apenas no período pós-Segunda Guerra Mundial) como uma ordem internacional pacífica e meio ambiente, (quanto ao primeiro, o de uma ordem internacional pacífica, a nosso ver poderiam ser elencados os esforços de concertação empreendidos por personagens como Bèze, na condição de embaixador da causa huguenote), e pela ênfase dada por esses primeiros calvinistas ao comando bíblico contido no Gênesis (Gen. 2:15), que em Deus exorta Adão e Eva a bem cuidarem do Jardim do Éden ${ }^{492}$.

492 WITTE Jr., John. The Reformation of Rights: Law, religion, and human rights in early modern Calvinism. Cambridge: Cambridge University Press, 2007, p. 36. 


\section{CONSIDERAÇÕES FINAIS}

\section{O MAGISTRADO, A LEI E A REPÚBLICA NO CALVINISMO CONSTITUCIONAL E O PONTO DE TOQUE ENTRE UM DISCURSO CONTRATUAL E UM CONSTITUCIONALISMO PROPRIAMENTE DITO}

Dentre todas as expressões da tradição da Filosofia Política, talvez as mais importantes sejam magistrado, lei e República. O resultado das interações entre elas compõe o núcleo do pensamento político calvinista vocacionado em sua origem a permitir a desobediência a comandos normativos derivados de um determinado poder tirânico, assim como a sua punição, sem desestruturar essa própria simbiose, e, mais além, permitir justamente a continuidade da sã relação entre tais artefatos políticos.

Para Calvino, que se vale da tradição clássica, as relações entre magistrado e lei são tão inerentes na estruturação de uma República que: "Depois dos governantes vêm as leis, que são os verdadeiros nervos, como diz Cícero, depois de Platão, a alma de todos os estados; pois sem elas os governantes não podem de modo algum subsistir. Porque, ao contrário, elas são conservadas e mantidas pelos governantes, visto que, sem eles, elas não teriam força alguma. Por isso não se pode dizer coisa mais certa do que chamar à lei de magistrado mudo e ao magistrado de lei viva." 493

Em Bèze se afere uma utilização da ideia de vocação já exposta nos textos teológicos da Instituição de Calvino, com um sentido de proteção a ponto de ser recorrente a afirmação de o magistrado ser o guardião de uma parcela do povo que lhe é comissionado, assim como a noção de funcionalidade das magistraturas, ou seja, a instituição da magistratura resta condicionada à proteção do povo, pois “[...] os povos não foram criados para os magistrados, mas o contrário os magistrados para os povos; como o tutor para o pupilo e não o pupilo para o tutor, e o pastor para o rebanho e não o rebanho para o pastor" ${ }^{, 494}$. O fundamento de tal ação protetiva é as boas leis de um Reino, que seus governantes e magistrados prometem cumprir, no momento de suas investiduras nos cargos.

Bodin, que manifestamente se engaja em responder à literatura protestante (que por sua vez, a nosso ver, em larga medida, constitui-se como resposta ao sutil convite deixado por Calvino em sua ambígua especulação, segundo a qual a França possuía mecanismos institucionais de controle dos governantes), na obra Os Seis Livros da República, alega que o

\footnotetext{
${ }^{493}$ CALVINO, João. Poder Civil. In: BONI, Alberto de (org.). Escritos Seletos de Martinho Lutero Tomás Müntzer e João Calvino. Petrópolis: Vozes, 2000, p. 254.

${ }^{494}$ BÈZE, Théodore de. Du Droit des Magistrats. Genève: Droz, 1970, p. 9.
} 
Reino francês deve ser considerado como uma monarquia, e o governante singular titulariza a soberania e seu pleno exercício, sem nenhum partilhamento.

Em preliminares, no prefácio da obra, Bodin reconhece os malefícios de uma tirania, assim como qualquer ensinamento que as estimule (como os de Maquiavel, no seu entender), pois “o Príncipe depravado por opiniões tirânicas, faz passar a penalidade antes da acusação, e a condenação antes da prova, que é o grande meio que se pode imaginar para arruinar os Príncipes e sua condição."495 Porém, contesta categoricamente, ainda no prefácio, os escritos monarcômacos como o de Bèze, Gentillet e Hotman (cuja edição antecede o surgimento do clássico de Bodin, sendo que as Vindiciae apenas apareceriam após a publicação de Os Seis Livros da República), ao referir-se a eles da seguinte forma :'Existem outros contrários e diretos inimigos destes, que não são menos, e talvez mais perigosos, que sob o véu de uma isenção de encargos [os comandos do soberano] e liberdade popular, fazem rebelar os sujeitos contra seus Príncipes naturais, abrindo as portas a uma licenciosa anarquia, que é pior do que a mais intensa tirania do mundo." 496

Referindo-se expressamente às faculdades de controle dos monarcas franceses como aquelas vislumbradas por Hotman nas Assembleias Gerais, Bodin as vê como impossíveis, pois caso elas fossem reais, os signos de poder da República tais como "os éditos e ordenações [seriam] publicadas em nome dos estados e exigidas pelos estados, como em uma senhoria Aristocrática [...]”497, algo não vislumbrável no reino da França. Além do mais, conforme salienta Alberto Ribeiro Barros, para Bodin, sustentar que numa monarquia legítima é possível se alegar a submissão dos príncipes à vontade dos Estados Gerais seria uma contradição $^{498}$, uma vez que não havendo situações exepcionais como o príncipe estar sequestrado, louco ou na menoridade, nada pode justificar a sujeição do rei aos Estados, já que caso "o Príncipe soberano [for] sujeito aos estados, ele não é nem Príncipe, nem soberano, e a República não é nem reino, nem Monarquia, mas uma pura Aristocracia de vários senhores em igual poder.",499

Bodin, em sua investigação do papel possível que pode exercer a assembleia dos Estados Gerais, confere-lhe apenas a função consultiva, não podendo em hipótese nenhuma

\footnotetext{
${ }^{495}$ BODIN. Les Six Livres de la République. v. I. Paris: Fayard, 1986, p. 14

496 Ibidem, p. 14.

${ }^{497}$ Ibidem. p. 199. Bodin alega que de suas investigações quanto ao papel dos estados nada mais se pode aferir do que sujeição, serviço e obediência conforme o registro dos discursos das assembleias ocorridas em Tours e Orléans. BODIN. Op. cit., p. 199.

498 BARROS, Alberto Ribeiro de. A teoria da soberania de Jean Bodin. São Paulo: Ed. Unimarco e Fapesp, 2001, p. 283.

${ }^{499}$ BODIN. Op. cit., p. 199.
} 
vincular a plena discricionariedade do príncipe quanto aos negócios públicos, pois reconhecer a importância dos Estados não quer dizer "que seja necessário a ele [o rei] se vincular aos seus pareceres, ou que o Rei não possa fazer o contrário do que eles pedem, se a razão natural, e a justiça de seu querer lhe assistem. E nisso se reconhece a grandeza e a majestade de um verdadeiro Príncipe soberano, quando os estados do povo estão em assembleia, apresentando requisições e súplicas ao seu Príncipe com humildade, sem ter qualquer poder de ordenar, nem de discernir, nem qualquer voz deliberativa; assim o que agrada ao rei, é tido por lei, por édito, por ordenança."

Quanto aos magistrados inferiores, Bodin também não vislumbra qualquer possibilidade de resistir aos comandos dos reis, ainda que o autor reconheça uma grande dignidade no cargo, a ponto de ser considerado, depois do soberano, "a pessoa principal da República"501, e esclarece ser seu principal dever a obediência ao soberano que lhe comunicara "a autoridade, a força, e o poder de comandar" 502 .

No que se refere aos juramentos feitos pelos príncipes que, entre os autores huguenotes, se prestavam como garantia de controle e sujeição dos governantes às leis, Bodin, apesar de inicialmente aparentar uma concordância com as premissas utlizadas pelos monarcômacos, imediatamente deixa claro sua posição contrária, ao dizer: "pois ainda que nós tenhamos dito que o Príncipe deve guardar o juramento feito por ele ao seu Povo, se ele se obrigou por juramento, ele deve não obstante guardar as leis do estado e República onde ele é soberano. No entanto, não se deve concluir que se o Príncipe contravenha em tal caso ao seu dever [de se vincular ao juramento feito ao seu povo], que o magistrado não lhe obedeça, pois não cabe ao magistrado tomar conhecimento ou se opor de forma alguma à vontade de seu príncipe ou leis humanas, as quais o príncipe pode derrogar."503

Quanto às leis civis, Bodin deixa claro a inutilidade de qualquer discussão sobre o assunto, pois a verdadeira vinculação numa República ocorre com o magistrado em relação à lei, fenômeno que, como vimos, não se repete em relação ao soberano. Assim, Bodin descreve o vínculo incondicional do magistrado em relação às leis civis emanadas do soberano: "mas o magistrado quando se trata da justiça civil somente deve verificar e colocar em execução os mandamentos mesmo que ele pense que eles sejam civilmente iníquos. Eis porque em toda

\footnotetext{
${ }^{500}$ BODIN. Les Six Livres de la République. v. I. Paris: Fayard, 1986, p. 198.

${ }^{501}$ Ibidem, p.91.

502 Ibidem, p. 91.

${ }^{503}$ Ibidem, p. 98.
} 
República se faz jurar todos os Magistrados de guardar as leis e ordenanças, a fim de que eles não coloquem em discussão o que se deve ter por resolvido."

Ainda que para Bodin as leis naturais sejam limites concretos para a atuação dos governantes soberanos, já que não lhes são facultadas a sua derrogação como ocorre no caso das leis humanas, ele esclarece que o magistrado deve ter prudência, e mesmo duvidar de si, ao emitir o juízo de que um dado comando do príncipe soberano é contrário à natureza. E se por acaso efetivamente ocorrer de forma obstinada o desrespeito às leis naturais por parte de soberano, após o magistrado respeitosamente o advertir, o magistrado não deve dar execução a tais comandos, e em hipótese nenhuma resistir ao príncipe, pois "é muito mais conveniente para a república e mais assentado para a dignidade do magistrado se demitir de seu estado (como fez o Chanceler de Felipe II. Duque da Borgonha) do que dar execução a alguma coisa iníqua" ${ }^{\text {505 }}$.

Em suma, na teoria da soberania de Bodin, componentes (como magistraturas inferiores e assembleias representativas dos Estados Gerais) da estrutura de uma comunidade política assentada num regime monárquico, como era, em sua visão, a França de seu tempo, não estariam, em hipótese nenhuma, legalmente autorizados a exercerem licitamente qualquer direito de resistência, ou sequer de contrariar o soberano (que se confundiria como o monarca no caso específico francês), uma vez que sob a perspectiva lógica do binômio conteúdocontinente, o soberano contém em seu poder esses órgãos e não é contido por estes, ou como bem explica Simone Goyard-Fabre numa bela metáfora: "Da mesma forma que o Sol ilumina de uma única lua a pluralidade dos seres, da mesma maneira o soberano é um poder uno e indivisível dos corpos políticos do qual os múltiplos órgãos são constituídos, cada um de sua justa forma e sua justa função pelas diversas magistraturas."

De forma análoga, no século XVII, Hobbes, em o Leviatã, compartilha das mesmas teses de Bodin, ao entender que a soberania não pode ser partilhada e o exercício de poder por quaisquer agentes políticos é feito por mera delegação do soberano, não sendo possível qualquer incompatibilidade entre os comandos do soberano com os de seus delegatários, o que a priori exclui qualquer exercício do direito de resistência por magistrados inferiores.

No capítulo XXIII, Dos Ministros Públicos do Poder Soberano, na parte 2 do tratado que versa sobre a República, em o Leviatã, Hobbes define o ministro público como

\footnotetext{
${ }^{504}$ BODIN. Les Six Livres de la République. v. I. Paris: Fayard, 1986, p. 100.

505 Ibidem, p. 105.

${ }^{506}$ GOYARD-FABRE, Simone. Jean Bodin et le droit de la République. Paris: PUF, 1989, p. 134.
} 
aquele "encarregado pelo soberano (quer este seja um monarca ou uma assembleia) de qualquer atividade, com autoridade, no desempenho desse cargo, para representar a pessoa da república" ${ }^{507}$. Para Hobbes, ocorre a impossibilidade de qualquer comando dessas autoridades regionais mostrar-se incongruente com os do soberano, pois:

No caso de só uma parte, ou província, tanto um monarca como uma assembleia soberana podem entregar a sua administração geral a um governador, lugar-tenente, prefeito ou vice-rei. E também neste caso todos os habitantes dessa província são obrigados a fazer tudo quanto ele ordenar em nome do soberano, e que não seja incompatível com o direito do soberano. Porque esses pretores, vice-reis e governadores só têm como direitos aqueles que dependem da vontade do soberano. E nenhuma delegação de poder que lhes seja feita pode ser interpretada como uma declaração da vontade de transferir a soberania, sem que haja palavras expressas e evidentes para tal fim. E esta espécie de ministros públicos assemelha-se aos nervos e tendões que movem os diversos membros de um corpo natural. ${ }^{508}$

Quanto ao argumento de o soberano estar vinculado às leis conforme ocorre na literatura calvinista, no capítulo sobre as Leis Civis, Hobbes refuta categoricamente essa possibilidade, uma vez que o soberano mantém o monopólio da legiferação, como também o de revogar as leis: "O soberano de uma república, [...], não se encontra sujeito às leis civis. Como tem o poder de fazer e revogar as leis, pode, quando lhe aprouver, [libertar-se] dessa sujeição, revogando as leis que o estorvam e fazendo outras novas: por consequência, já antes era livre."

Posta a apresentação das teses diametralmente opostas às de nosso autor, quanto à possibilidade de partilhamento no exercício do poder soberano, cumpre apontarmos os desdobramentos da boa fortuna desta literatura política nos países anglo-saxões, e sua miséria em solo francês, principalmente no que tange à proteção dos magistrados inferiores e o poder dos Estados Gerais defendidos por nosso autor.

Depois da destituição do soberano espanhol Felipe II, na Holanda, evento em que se vislumbra uma boa síntese dos argumentos calvinistas de governos controláveis por

\footnotetext{
${ }^{507}$ HOBBES, Thomas. Leviatã. São Paulo: Martins Fontes, 2003, p. 204.

${ }^{508}$ Ibidem, p. 205.

${ }^{509}$ Ibidem, p. 227.
} 
mecanismos institucionais. Cronologicamente, a Revolução Gloriosa constitui a primeira grande operacionalização das ideias do pensamento político huguenote, como a afirmação inequívoca da supremacia do parlamento sobre a realeza e a plena independência dos juízes ingleses graças ao Judges Bill, em 1691-92 e o Act of Settlement, de 1701, que promoveram um judiciário independente, pela impossibilidade de ser demitido pelo rei e pelo caráter vitalício de seus cargos ${ }^{510}$.

Do ponto de vista de Berman, no complexo processo revolucionário sobre o qual a Inglaterra calvinista viria a assentar suas instituições, é necessário se fazer referência ao fortalecimento do parlamento perante os reis, uma vez que, antes de 1640, o governo inglês não passava de uma monarquia absoluta, na qual o rei governava com seu conselho próprio e convocava o parlamento de forma intermitente. Já, depois de 1689, estabilizou-se uma forma de governo que era "uma monarquia constitucional na qual o Parlamento se reunia continuamente e era supremo, embora o rei e seu conselho, com o consentimento do Parlamento, mantivesse um poder substancial, especialmente com relação às relações exteriores e as colônias ultramar."511

Uma das vozes mais veementes que se insere na tradição de utilização dos argumentos do calvinismo político do século XVI dentro dos debates de fortalecimento das prerrogativas parlamentares perante os reis seria Jonh Milton, cuja obra, Defesa do povo inglês, foi uma resposta a outra obra de defesa das prerrogativas reis, A Defesa Régia, de Salmásio. Nessa obra, Milton acolhe amplamente as ideias desenvolvidas pelos calvinistas continentais do século anterior sobre os Estados Gerais, que mutatis mutandis caberiam perfeitamente no papel a ser desempenhado pelo parlamento inglês, conforme se lê:

Certamente, se o Parlamento pode, sem a vontade e o consentimento do rei revogar e rescindir seus atos e os privilégios concedidos a qualquer pessoa, circunscrever as próprias prerrogativas régias conforme julgar melhor, diminuir seu rendimento anual, as despesas da corte, seu séquito e em suma todos os negócios da casa real; se pode afastar até mesmo seus conselheiros e amigos pessoais, ou mesmo arrancá-los de seu seio para puni-los; em resumo, se por lei é assegurado a qualquer pessoa recurso a respeito de

${ }^{510}$ BERMAN, Harold J. Law and Revolution, The Formation of the Western Legal Tradition. v. II, Cambridge, Massachusetts \& London, England: Harvard University Press, 1983, p. 227.

${ }^{511}$ Ibidem, p. 207. 
qualquer matéria do rei para o Parlamento, porém não inversamente, do Parlamento para o rei - e tanto os registros públicos como os mais doutos de nossos juristas testemunham que isso pode acontecer e muitas vezes acontece - , suponho que não haja ninguém, pelo menos de boa-fé, que não admita a superioridade do Parlamento em relação ao rei. Pois mesmo num interregno o Parlamento viceja e - como se encontra muito bem atestado em nossas histórias - não raro, sem nenhuma consideração pela linhagem hereditária, institui como rei por intermédio de livre voto o homem a quem julga mais apropriado.

Resumindo então como ficam as coisas: o Parlamento é o conselho supremo da nação constituído por pessoas completamente livres e dotadas de pleno poder para o propósito de consultarem juntas sobre as questões mais importantes. O rei foi criado para cuidar que se cumprissem todas as resoluções geradas pelo parecer e pela opnião desses estados. ${ }^{512}$

Importa registrarmos ainda que, apesar dos poderes diagnosticados dos magistrados inferiores na obra de Bèze e na de Hotman (ambos reconhecendo um empoderamento desses órgãos, parlamentos judiciais e também de outras naturezas políticas $^{513}$ desde a Idade Média), os mesmos sofreriam no ano de 1641, com o édito de SaintGerman, um duro golpe relativo ao empreendimento de colocar limites ao poder real. Em tal documento, o poder real assim institui sua supremacia em relação a tais cortes: "Declaramos que nossa corte do parlamento de Paris e todas as outras não foram estabelecidas para dar justiça a nossos súditos; seus feitios muito expressam inibições e proibições, não somente de receber, no futuro, o conhecimento de alguns negócios semelhantes àqueles que foram até agora enunciados, mas geralmente de todos aqueles que nos reservamos a nossa pessoa somente... a não ser que nós lhe dermos o poder e o mandamento especial por nossas cartas patentes." 514

\footnotetext{
512 MILTON, Jonh. Defesa do povo inglês. In: DZELZAINIS, Martin (org.). Escritos Políticos. São Paulo: Martins Fontes, 2005, p. 286-287.

${ }^{513}$ Richard Roy Benert, partindo das referências de nossa contemporaneidade de organização política (funções executiva, judicial e legislativa), assim descreve o poder exercido pelos agentes políticos que Bèze confere à função protetiva do povo: "os magistrados inferiores possuem tanto as funções legislativa e judiciária, e ao mesmo tempo são co-executores. Eles partilham suas funções legislativa, judicial e executiva como membros de um corpo só, formando um governo cuja real natureza incluiria meios de limitar e resistir ao Rei." BENERT, Richard Roy. Inferior Magistrates in Sixteenth-Century Political and Legal Thought. Tese Inédita. University of Minnesota, 1967, p. 193-194.

${ }^{514}$ Édito de Saint-Germain, 1641 apud BIGOT, Grégoire. Introduction historique au droit administrative depuis 1789. Paris: PUF, 2002, p. 22.
} 
Quanto à convocação dos Estados Gerais, o caminho progressivo do absolutismo francês, também amparado pela destituição da competência dos parlamentos regionais de julgar as causas pertinentes à administração real, faz com que os mesmos adormeçam de 1614 até quase às vésperas da Revolução Francesa. E não se pode falar de efetivos controles parlamentares na posteridade imediata de Bèze, caminho que, conforme foi visto, será diametralmente oposto do outro lado do Canal da Mancha, dentre outros fatores, graças a autores que se valeram em seus escritos da autoridade do pensamento político de calvinistas continentais do século XVI, como fizera Jonh Milton.

Valendo-nos da longa tradição do pensamento político ocidental de reccorer à metáfora orgânica para explicar as organizações políticas, num exercício análogo ao dos evolucionistas da Biologia, que recorrem ao método de anatomia comparada, talvez caiba fazermos o registro de duas práticas constitucionais contemporâneas, exercidas por órgãos judiciais ou assemelháveis ${ }^{515}$, e por órgãos legislativos que guardam certas similaridades com os controles dos governantes propostos por Bèze em seu tratado. Mais especificamente, tratase de um paralelismo entre a ação dos magistrados inferiores e o dos Estados Gerais, respectivamente, com o controle jurisdicional da Administração Pública e os mecanismos de controles parlamentares, como os institutos do impeachment exercido pelo Senado, que guardam certa analogia com a deposição do tirano, nos sistemas presidencialistas, ou ainda nos sistemas parlamentaristas, a aptidão do parlamento destituir o gabinete de governo pela aprovação do voto de censura ou a reprovação da moção de confiança.

$\mathrm{O}$ advento de tais mecanismos de controle dos governantes, na época atual, é comumente associado aos eventos revolucionários da França e da América do Norte do século XVIII, ditos inspirados por ideias iluministas. Porém cumpre fazermos referência ao ensaio de John Witte Jr., The Reformations of Rights: Law, Religion, and Human Rights in early Modern Calvinism, em que o autor aponta uma tradição, ao longo dos séculos, de diálogo interno entre autores calvinistas (Bèze, Althusius, Milton e os Puritanos da Nova Inglaterra), no qual a ideia de controle dos governantes é uma constante. ${ }^{516}$

\footnotetext{
${ }^{515}$ Curiosamente, a expressão magistrado, que no século XVI comportava uma série de funções tipicamente executivas (como coletar impostos, força policial, força armada, funções diplomáticas, etc), além daquilo que denominamos de função judicial, porém, como nos dias atuais, a palavra fora condicionada para tão somente designar participantes daquilo que denominamos Poder Judiciário, ou instituições que orbitam sua estrutura (na França e na Itália também designam o Ministério Público), sendo que, em regra, juízes ou agentes públicos equiparáveis são constitucionalmente autorizados a liberar licitamente da obediência qualquer pessoa que sofra o arbítrio de um governante.

516 John Witte Jr. afirma que: "O Bill of Rights [as 10 primeiras emendas] para a Constituição Americana fora defendido em sua época sobre uma variedade de fundamentos - com argumentos Iluministas entre os mais conhecidos. [...] entretanto, cada uma das garantias do Bill of Rights em 1791 tinha sido formulada nos dois
} 
Em Bèze, conforme foi visto, poderia mesmo ser apontada a origem da tradição do Calvinismo como um corpo sistematizado de saberes teólogicos e práticas políticas, mais precisamente em sua obra Du Droit des Magistrats, um contratualismo que não se confunde com os de Hobbes ou de Rousseau, não por suas consequências, mas sobretudo por suas razões de existência, já que para Bèze tal contratualismo não se referiria a uma origem da sociedade e da instituição de um poder político, mas um contratualismo para o qual, conforme explica Nicola Matteucci, "o contrato é amiúde também um fato histórico, ou seja, parte integrante de um processo político que leva ao constitucionalismo e, em especial, à necessidade de limitar o poder do Governo por meio de um documento escrito que estabeleça os respectivos e recíprocos direitos-deveres. ${ }^{~ 517}$ A concretude de tal contrato, em Bèze, seria sobretudo aferível pelo juramento entre o povo e o soberano, no momento da sagração daquele.

séculos prévios - por teólogos e juristas calvinistas, entre outros. Alguns desses direitos já tinham sido formulados por Théodore Beza e os combatentes da resistência francesa e escocesa no século XVI [...] Além do mais, uma série de ideias centrais do constitucionalismo americano - soberania popular, federalismo, separação de poderes, freios e contrapesos, separação entre estado e igreja, dentre outros - foram consideravelmente formulados por Calvinistas nos dois séculos antecedentes. (WITTE Jr., John. The Reformation of Rights: Law, religion, and human rights in early modern Calvinism. Cambridge: Cambridge University Press, 2007, p. 31). O mesmo comentador ora citado não se exime em reconhecer também uma longa lista de vítimas que, por causa de suas convicções religiosas, sofreram toda sorte de punições: exílio, prisão, censura, tortura e mesmo a morte, ao se confrontarem com lideranças calvinistas em suas comunidades. A título emblemático pode-se citar os nomes de Michel Servetus, Jean Morély, Jacob Arminius, Hugo Grotius, Richard Overton, Jonh Liburne, Roger Williams, e Anne Hutchinson, além do mais, quase que num paradoxo às tradições de liberdades públicas cultuadas pelos autores calvinistas ao longo dos séculos, é preciso reconhecer um lado obscuro dessa literatura política, pois "É bastante fácil encontrar [em alguns dos] tratados e sermões Calvinistas de ambos os lados do Atlântico, uma séria defesa de toda forma de monarquia, escravidão, chauvinismo, racismo, fanatismo, elitismo, perseguição, e outras formas vergonhosas de paixões e injustiça. Qualquer avaliação honesta da tradição Calvinista do direito, religião, e direitos humanos deve reconhecer essas brutalidades.” (WITTE Jr., John. The Reformation of Rights: Law, religion, and human rights in early modern Calvinism. Cambridge: Cambridge University Press, 2007, p. 31). Outro aspecto sombrio, que perfeitamente poderia ser somado às referências anteriores de Witte Jr., seria um embasamento ideológico que a própria noção política calvinista de bons governos daria ao imperialismo norte-americano, realidade principalmente aferível na figura do presidente T. Woodrow Wilson, conforme explica Robert Freeman Smith: "Em 1913, Thomas Woodrow Wilson foi eleito presidente dos Estados Unidos. Sua administração estava profundamente enraizada na visão calvinista e secularizada da nação redentora com uma missão e um destino peculiares. [...] Woodrow Wilson acreditava firmemente na missão nacional de introduzir a paz, a ordem e a estabilidade no mundo. E enfatizou o papel das instituições anglo-americanas no estabelecimento dessas condições. Em sua opinião, as revoluções aconteciam ou porque homens maus estavam tentando usurpar o poder por meios inconstitucionais [numa atualização da ideia de tirania de origem], ou porque as pessoas eram impossibilitadas de votar em eleições livres. Não ocorreriam revoluções se houvesse eleições, se os preceitos constitucionais fossem obedecidos e os homens maus afastados do poder. Para Wilson, a ordem constitucional é o alicerce da ordem e da estabilidade. O presidente pôs muita ênfase no governo exercido por homens bons que seguem os preceitos constitucionais. Mas os países nem sempre escolhem tais homens para seus líderes. Assim, quando Sir William Tyrrell pediu a Wilson, em novembro de 1913, que explicasse sua política com relação ao México, o presidente respondeu: "Vou ensinar as repúblicas sul-americanas a eleger homens bons." SMITH, Robert Freeman. Os Estados Unidos e a América Latina, 1830-1930. In: BETHELL, Leslie (org.). História da América Latina. v. IV. São Paulo: Imprensa Oficial, Fundação Alexandre de Gusmão, 2002.

517 MATTEUCCI, Nicola. Contratualismo. In: BOBBIO, Norberto et. al. Dicionário de Política. v. I. Brasília: Editora Unb, 2000, p. 281. 
Para Patricia Hills Finlayson “o que Bèze quer provar é que sempre há condições atreladas entre o governante e o súdito, o que leva sempre ser o governante limitado por certas condições e, além disso, se um governante violar essas condições, alguém abaixo de Deus tem o direito de fazer algo" ${ }^{" 518}$. Estes seriam os entes institucionais de seu tempo, os Estados Gerais e os magistrados inferiores, e para Isabelle Bouvignes, a grande preocupação de Théodore de Bèze seria uma substituição da lógica providencialista, que inclusive extraordinariamente autorizaria o tiranicídio perpetrado por um homem em particular, por uma lógica propriamente humana e temporal, que denunciaria o tirano, e esquadrinharia outra organização política, ainda sim feita pelos mesmos homens. ${ }^{519}$

Percebe-se na mais política das obras de Théodore de Bèze, Du Droit des Magistrats, ainda que embrionários, mas solidamente esboçados, elementos dos mecanismos de controle dos governantes inerentes aos sistemas representativos e democráticos de nosso tempo, como a anulação de atos viciados de ilegalidade exarados por governos, ou mesmo a destituição ou a penalização de governantes por órgãos parlamentares ou judiciais, em nada desfazendo, mas preservando incólume a mesma comunidade política organizada pelos próprios homens, em larga medida, sem intervenções extrógenas a uma sintaxe entre governados e governantes, mundana e pactuada.

\footnotetext{
${ }^{518}$ FINLAYSON, Patricia Hills. Resistance Theory in Du Droit des Magistrats. Tese Inédita. University of Minnesota, 1965, p. 50.

519 BOUVIGNIES, Isabelle. Monarchomachie: tyrannicide ou droit de résistance?. In: PIQUÉ, Nicolas; WATERLOT, Ghislain. Tolérance e Réforme: elements pour une généalogie du concept de tolérance. Paris: L' Harmattan, 1999, p. 96.
} 


\title{
REFERÊNCIAS BIBLIOGRÁFICAS
}

\author{
Obras de Bèze:
}

BÈZE, Théodore. Abraham Sacrifiant. Genève: Droz, 1967.

Chrestiennes Méditations. Genève: Droz, 1964.

Du droit des magistrats. Genève: Droz, 1971.

. Confession de la foi chrestienne, $2^{\circ}$ version (1560 et ss.), Point V, article

XLV. (Apêndice II) In: Du Droit des Magistrats. Genève:, p. 70-75, 1970.

. De haereticis a civili magistratu puniendis... (1554). (Apêndice I) In:

Du Droit des Magistrats. Genève: Droz, p. 69-70, 1970.

\section{Fontes Primárias:}

AgOStinho. A Cidade de Deus Contra os Pagãos. 2 vols. Bragança Paulista: Ed. Universitária São Francisco, 2006.

ALMAIN, Jacques. Sobre a Autoridade da Igreja. In: BURNA, J. H.; IZBICKI, T. M. Conciliarism and Papalism. Cambridge: University Cambridge Press, p. 134-200, 1997.

AQUINO, S. Tomás de. Súmula Teológica. In: DZELZAINIS, Martin (org.). Escritos Políticos. Petrópolis: Vozes, 1997.

- Do Reino ou do governo dos príncipes ao Rei de Chipre. In: DZELZAINIS, Martin (org.). Escritos Políticos. Petrópolis: Vozes, 1997.

Bíblia de Jerusalém. São Paulo: Paulus, 2006.

BODIN. Les Six Livres de la République. 6 vols. Paris: Fayard, 1986.

BRUTUS, Etienne Junius. Vindiciae contra Tyrannos. Genève: Droz, 1979.

CALVINO, João. A Instituição da Religião Cristã. 2 Tomos. São Paulo: Unesp, 2007.

Poder Civil. In: BONI, Alberto De (org). Escritos Seletos de Martinho Lutero, Tomás Müntzer e João Calvino. Petrópolis: Vozes, 2000.

- Sobre o Governo Civil. In: CALVINO, João. Lutero e Calvino, Sobre a Autoridade Secular. São Paulo: Martins Fontes, p. 86, 2005. 
CÍCERO. Dos Deveres. São Paulo: Martins Fontes, 1999.

CORPO DEL DIRITTO (DIGESTO). Vol. I-X. GOTOFREDO, Dionisio; FREIESLEBEN, C. E.; VIGNALI, Giovanni. (Coord.) Edição Bilingüe latim-italiano. Napoli: Vincenzo Pezzuti Editore, 1856-1862.

DIGESTO DE JUSTINIANO. Tomo I-II. Tradução: A. D`Ors; F. Hernandez-Tejero; P. Fuenteseca, M. Garcia-Garrido; J. Burillo. Pamplona: Aranzada, 1968-1972.

Excertos dos Registros do Conselho de Genebra, sobre a impressão de Du Droit des magistrats e Des Mémoires de l' estat de France sous Charles neufiesme. (Apêndice III) In: BÈZE, Théodore de. Du Droit des Magistrats. Genève: Droz, p. 76-78, 1970.

GENTILLET, I. Discours sur les moyens de bien gouverner et maintenir en bonne paix un Royaume ou autre Principauté. Contre Nicolas Machiavel Floretin. Genève: Droz, 1968.

HOBBES, Thomas. Leviatã. São Paulo: Martins Fontes, 2003.

HOTMAN, F. Antitribonian. Saint-Etienne: Editions de la Université, 1980.

La Gaule Française (Franco-Gallia). Paris: Fayard, 1991.

KINGDON, Robert. M. (org.). Registers of the Consistery of the Geneva in the Time of Calvin, 1542-1544. v. 1. Cambridge: Eerdmans Publishing Co, 2000.

LÍVIO, Tito. História de Roma (Ab Urbe Condita Libri). São Paulo: Paumape, 1989.

LUTERO. Da Autoridade Secular, In: Boni, Alberto De (org). Escritos Seletos de Martinho Lutero, Tomás Müntzer e João Calvino. Petrópolis: Vozes, 2000.

. Acerca da questão, se também militares ocupam uma função bem-aventurada. In:

Martinho Lutero: Obras selecionadas. v. 6. São Leopoldo: Comissão Interluterana de Literatura, 1995.

Aos conselhos das cidades da Alemanha, para que criem e mantenham escolas. In:

Martinho Lutero: Obras selecionadas. v. 5. São Leopoldo: Comissão Interluterana de Literatura, 1995.

. Contra as Hordas Salteadoras e Assassinas dos Camponeses. In: BONI, Alberto

De (org). Escritos Seletos de Martinho Lutero, Tomás Müntzer e João Calvino. Petrópolis: Vozes, 2000.

Prefácio à Epístola de São Paulo aos Romanos (1522). In: LUTERO, Martinho. Da Liberdade do Cristão (1520). São Paulo: Unesp, 1997.

MAIR, John. Uma disputatio sobre a autoridade do concílio sobre o supremo pontífice. In: BURNA, J. H.; IZBICKI, T. M. Conciliarism and Papalism. Cambridge: University Cambridge Press, p. 285-311, 1997. 
MELANCHTON, Philip. Loci Communes Theologici. In: PAUCK, Wilhelm. Melanchton and Bucer. Philadelphia: The Westminster Press, 1969.

MILTON, Jonh. Escritos Políticos. São Paulo: Martins Fontes, 2005.

POLÍBIOS. História. 2.ed. Brasília: UNB.

ROUSSEAU, J. J. Considerações sobre o Governo da Polônia e sua Reforma Projetada. São Paulo: Brasiliense, 1982.

SEYSSEL, C. La Monarchie de France. Paris: Librairie d`Argences, 1965.

\section{Fontes Secundárias:}

ALLEN, J. A history of political thought in the sixteenth century. London: Methuen, 1960.

ALVES, José Carlos Moreira. Direito Romano. v. II. Rio de Janeiro: Forense, 1998.

ARANOVICH, Patrícia Fontoura. História e Política em Maquiavel. São Paulo: Discurso Editorial, 2007.

ARMOSTRONG, E. The political theory of the Huguenots. In: English historical review. T. IV, p. 13-40, 1889.

ATALIBA, Geraldo. Constituição e República. 2. ed. São Paulo: Malheiros, 2001.

BAIARD, Henry Martyn. Théodore Beza the Counsellor of the French Reformation 1519 to 1605. Kessinger Publishing.

BARBOSA,Rui. A Supremacia da Judiciatura. In: Teoria Política. Rio de Janeiro: W. M. Jackson, 1952.

BARROS, Alberto. A teoria da soberania de Jean Bodin. São Paulo: Unimarco, Fapesp, 2001.

Direito nacional e Estado moderno. In: Cadernos de ética e Filosofia Política. n.6, 1/2005, 2005.

O direito de resistência na França renascentista. In: Kriterion, v. 47, n.

113.

BAYLOR, Michael G. Introdução. The Radical Reformation. Cambridge: Cambridge University Press, 1991.

BENERT, Richard Roy. Inferior Magistrates in Sixteenth-Century Political and Legal Thought. Tese Inédita. University of Minnesota, 1967. 
BERCÉ, Yves-Marie. O Rei Oculto Salvadores e Impostores Mitos políticos populares na Europa Moderna. São Paulo, Bauru: Imprensa Oficial, Edusc, 2003.

BERMAN, Harold J. Law and Revolution. v. I e II. Cambridge, Massachusetts. London, England: Harvard University Press, 2003.

BETHELL, Leslie. História da América Latina. v. IV. São Paulo: Edusp, 2002.

BIGOT, Grégoire. Introduction historique au droit administrative depuis 1789 Paris: PUF, 2002.

BIGNOTTO, Newton. Origens do Republicanismo Moderno. Belo Horizonte: UFMG, 2001. . O Tirano e a Cidade. São Paulo: Discurso Editorial, 1998.

BISSON, T. N. The Medieval Crown of Aragon. Oxford: University Press, 1986.

BLYTHE, James M. Ideal Government and Mixed Constitution in the Middle Ages. Priceton: Priceton University Press, 1992.

BOBBIO, N. Dicionário de Política. Brasília: UNB, 2000.

BONAVIDES, Paulo. Curso de Direito Constitucional. São Paulo: Malheiros,. 2007.

BOUVIGNIES, Isabelle. Monarchomachie: tyrannicide ou droit de résistance?. In: PIQUÉ, Nicolas; WATERLOT, Ghislain. Tolérance e Réforme: elements pour une généalogie du concept de tolérance. Paris: L' Harmattan, 1999.

BOUWSMA, William J. Venice and the Defense of Republican Liberty. Berkeley \& Los Angeles: University of California Press, 1984.

BLOCH, Marc. Os reis taumaturgos. São Paulo: Companhia das Letras, 2005.

BURKI, E. P. Thomas Hobbes et Théodore de Bèze deux lecteurs de la Bible. In: Cahiers de Philosophie politique et juridique de l' Université de Caen. n. 3, p. 75-85, 1903.

BURNS, J. Jean Bodin and the end of medieval constitucionalism. In: Actes du colloque international Jean Bodin. Munich: Verlay, p. 167-186, 1973.

CALLICÓ, Jaume Sobrequés i. Historia de Cataluña. Barcelona: Editorial Base, 2007.

CANNING, Joseph. The Political Thought of Baldus de Ubaldis. Cambridge: Cambridge University Press, 2003.

CARVAJAL, Patrício. El derecho de resistência en la teologia política de Juan Calvino. Rev. Estud. Hist-juríd. n. 22, p. 335-351, 2000.

CASTRO, J. O contratualismo ideológico do "Vindiciae contra tyrannos". Belo Horizonte, UFMG: 1960. Tese de Livre-docência. Universidade Federal de Minas Gerais, 1960. 
CÍCERO. Pensamentos Políticos Selecionados. São Paulo: Nova Alexandria, 2000.

CHEVALLIER, Jean-Jacques. As grandes obras políticas. Rio de Janeiro: Agir, 1998.

CHURCH, W. Constitutional Thought in Sixteenth-Century France. Boston: Harvard University Press, 1941.

COLLINSON, Patrick. A Reforma. Rio de Janeiro: Objetiva, 2006.

CORTINA, Adela. Aliança e Contrato. Política, Ética e Religião. São Paulo: Loyola.

DALlARI, Dalmo de Abreu. Elementos de Teoria Geral do Estado. 23 ed. São Paulo: Saraiva, 2002.

ELLIOTT, Neil. Romanos 13, 1-7 no contexto da propaganda imperial. In: HORSLEY, Richard A. Paulo e o império, religião e poder na sociedade imperial romana. São Paulo: Paulus, 2004.

FAVOREU, Louis. As Cortes Constitucionais. São Paulo: Landy, 2004.

FERREIRA FILHO, Manoel Gonçalves. Curso de Direito Constitucional. São Paulo: Saraiva, 1993.

FINLAYSON, Patricia Hills. Resistance Theory in Du Droit des Magistrats. Tese Inédita. University of Minnesota, 1965.

FIORAVANTI, Maurizio. Constitution, de la antiguiidad a nuestros dias. Madrid: Trotta, 2001.

FOSTER, Herbert D. Political Theories of Calvinists before the Puritan Exodus to America. American Historical Review, v. XXI, 1915.

FRANKLIN, Julian H. Constitutionalism and resistance in the sixteenth century: the protestant monarchomachs. In: SPITZ, David. Political Theory and Social Change. New York: Atherton, 1967.

. Introduction. Constitutionalism and Resistance in the Sixteenth Century: Three Treatises by Hotman, Beza \& Mornay. New York: Pegasus, 1969.

Sovereignty and the mixed constitution: Bodin and his critics. In: BURNS, J. H.; GOLDIE, Mark. The Cambridge History of Political Thought, 1450-1700. Cambridge: Cambridge University Press, p. 299-328, 2004.

GAETA, F. La Naissance de l'Etat Moderne em Italie: Milan ou Venise? In: Théorie et Pratique Politique a la Renaissance. Paris: Libraire Philosophique J. Vrin, 1977.

GALASSO, Giuseppe. Poder e Instituições em Itália, Da queda do Império Romano aos nossos dias. Lisboa: Bertrand, 1984.

GARCIA, Maria. Desobediência Civil Direito Fundamental. 2. ed. São Paulo: Revista dos Tribunais, 2004. 
GIESEY, R. If Not, Not, the oath of the aragonese and the legendary laws of sobrarbe. Priceton: Priceton University Press, 1968.

Medieval Jurisprudence in Bodin's concept of sovereignty. In: Actes du colloque international Jean Bodin. Munich: Verlay, p. 167-186, 1973.

. When and Why Hotman wrote the Francogallia. In: Bibliothèque `Humanisme

et Renaissance, n. XXIX, 1967.

GILSON, Etienne. A Filosofia na Idade Média. São Paulo: Martins Fontes, 2001.

\& Paulus, 2007.

Introdução ao estudo de Santo Agostinho. São Paulo: Discurso Editorial

GOYARD FABRE, Simone. Jean Bodin et le droit de la république. Paris: PUF, 1989.

HANCOCK, R. Calvin and the foundations of modern politic. New York: Cornell University Press, 1989.

HÖPFE, Harro. Introdução. In: CALVINO, João. Sobre a Autoridade Secular. Lutero e Calvino. São Paulo: Martins Fontes, 2005.

Fundamental Law and the Constitution in Sixteenth-Century France. In: Die Rolle der Juristen bei der Entstehub, 1986.

JOUANNA, Arlette; BOUCHER, Jacqueline; BILOGHI, Dominique; LE THIEC, Guy. Histoire et dictionnaire des guerres de religion, 155-1598. Paris: Robert Lafont, 1998.

LECLER, Joseph. Histoire de la tolérance au siècle de la Réforme. Paris: Albin Michel, 1994.

LLOYD, Howell A. Constitutionalism. In: BURNS, J. H.; GOLDIE, Mark. The Cambridge History of Political Thought, 1450-1700. Cambridge: Cambridge University Press, p. 254297, 2004.

LOPES, José Reinaldo de Lima. O Direito na História. São Paulo: Atlas, 2008.

KANTOROWICZ, Ernest H. Os Dois Corpos do Rei. São Paulo: Companhia das Letras, 1998.

KELlEY, Donald R. Law. In: BURNS, J. H.; GOLDIE, Mark. The Cambridge History of Political Thought, 1450-1700. Cambridge: Cambridge University Press, p. 66-94, 2004.

KELSEN, Hans. Jurisdição Constitucional. São Paulo: Martins Fontes, 2003.

KINGDON, R. Calvinism and resistance theory, 1550-1580. In: BURNS, J. H.; GOLDIE, Mark. The Cambridge History of Political Thought, 1450-1700. Cambridge: Cambridge University Press, p. 193-218, 2004.

Droz, 1971. Introduction. In: BÈZE, Théodore de. Du droit des magistrats. Genève: 
Beza `s Political Ideas as Expressed in his Sermons on the Passion. In: Théodore de Bèze (1519-1605): Actes du Colloque de Genève (septembre 2005), Travaux d`Humanisme et Renaissance, CDXXIV. Genève: Droz, 2007.

Les idées politiques de Bèze d'après son Traité de l' authorité Du magistrat em la punition des hérétiques. In: Bibliothèque d' Humanisme et Renaissance. v. 22, p. 565-569, 1960.

KOETSIER, L. S. Natural Law and Calvinist Political Theory. Victoria (Canadá): Trafford Publishing, 2003.

KRITSCH, Raquel. Soberania a Construção de um Conceito. São Paulo: Imprensa Oficial, 2002.

LADURIE, E. O Estado Monárquico-França 1460-1610. São Paulo: Companhia das Letras, 1997.

McILWAIN, Charles Howard. Constitucionalism, ancient and moderm. New York: Cornell University Press, 1958.

MAJOR, J. Representative Institutions in Renaissance France: 1421-1559. Madison, 1960.

MAYER, Otto. Derecho Administrativo Alemán. Tomo I, Parte Geral. Buenos Aires: Depalma, 1949.

MELLET, Paulo-Alexis. Du Passé au Présent: Les Sources du Droit des Magistrats sur leurs Sujets (1574). In: Théodore de Bèze (1519-1605): Actes du Colloque de Genève (septembre 2005), Travaux d’Humanisme et Renaissance, CDXXIV. Genève: Droz, 2007.

MELlO, Celso Antônio Bandeira de. Curso de Direito Administrativo. 21. ed. São Paulo: Malheiros Editores, 2006.

MESNARD, Pierre. L'essor de la Philosophie Politique au XVI Siècle. Paris: Libraire Philosophique J. Vrin, 1977.

MORAES, Alexandre. Direito Constitucional. 9. ed. São Paulo: Atlas, 2001.

NAPHY, William G. Calvin and the Consolidation of the Genevan Reformation. London: Westminster John Knox Press, 1994.

OAKLEY, Francis. Christian Obedience and authority, 1520-1550. In: BURNS, J. H.; GOLDIE, Mark. The Cambridge History of Political Thought, 1450-1700. Cambridge: Cambridge University Press, p. 159-192, ano 2004. PAUPÉRIO, Machado A. O direito político de resistência. Rio de Janeiro: Forense, 1978.

PEREIRA, Caio Mário da Silva. Instituições de Direito Civil: Contratos. v. III. Rio de Janeiro: Forense, 1981.

PÉRIGOT, Béatrice. Du Droit des Magistrats de Théodore de Bèze et Franco-Gallia de François Hotman: Deux Méthodes au service da la Philosophie Politique. In: Théodore de Bèze (1519-1605): Actes du Colloque de Genève (septembre 2005), Travaux d`Humanisme et Renaissance, CDXXIV. Genève: Droz, p. 553-567, 2007. 
PIETRO, Maria Sylvia Zanella Di. Direito Administrativo. 19. ed. São Paulo: Atlas, 2006.

PIÇARRA, Nuno. A Separação dos Poderes como Doutrina Constitucional. Coimbra: Coimbra Editora, 1989.

PISSARA, Maria Constança Peres. A República genebrina. In: Rousseau, Jean-Jacques. Cartas escritas da montanha. São Paulo: Unesp; PUC-SP, p. 23-24, 2006.

QUESADA, Sebastián; TAMAMES, Ramón. Imágenes de España. Madrid: Edelsa, 2001.

RATHÉ, C. Edward. Introduction. In: GENTILLET, I. Discours sur les moyens de bien gouverner et maintenir en bonne paix un Royaume ou autre Principauté. Contre Nicolas Machiavel Floretin. Genève: Droz, 1968.

RENS, Ivo. En quoi les idées politiques de Théodores de Bèze et des monarchomaques protestants innovèrent-elles? In: Jacques Godefroy (1587-1652) et l' humanisme juridique à Genève. p. 175-189.

REYNOLDS, B. Proponents of limited monarchy in the sixteenth century France: François Hotman and Jean Bodin. New York: CUP, 1931.

RICHARD, LIONEL. A República de Weimar. São Paulo: Cia das Letras, 1988.

RIVERO, Jean. Direito Administrativo. Coimbra: Livraria Almeida, 1981.

ROCHA, Paulo Roberto Pedroso. Aspectos da Vida Política segundo João Calvino. Dissertação de Mestrado (inédito). São Paulo: FFLCH-USP, 2000.

O Direito de resistência no Pensamento político da Reforma Protestante: os sistemas de João Calvino e Théodore de Bèze. Tese de doutorado (inédito). São Paulo: FFLCH-USP, 2005.

SABINE, George H. Historia de la teoria política. México: Fondo de Cultura Económica, 2006.

SEABRA, Fagundes. O Controle dos Atos Administrativos pelo Poder Judiciário. Rio de Janeiro: Forense, 2006.

SALMON, J. Francis Hotman and Jean Bodin: the dilema of sixteenth-century. In: History Today. t. XXIII. p. 801-809, 1973.

. Bodin and the monarchomachs. In: Actes du colloque international Jean Bodin. Munich: Verlay, p. 399-412, 1973.

SIGMUND, Paul E. Law and politics. In: KRETZMANN, Norman; STUMP, Eleonore. The Cambridge Companion to Aquinas. Cambridge: Cambridge University Press, p. 220, 1993.

SILVESTRE, Armando Araújo. Calvino e a Resistência ao Estado. São Paulo: Mackenzie, 2003 .

SKINNER, Quentin. As fundações do pensamento político moderno. São Paulo: Companhia das Letras, 2000. 
SOUZA, Christine Alves de. L' apport de Théodore de Bèze a la Théorie Du Droit de Résistance dans le Traité Du Droit des Magistrats. In: Jacques Godefroy (1587-1652) et l' humanisme juridique à Genève, p.191-216.

STROHM, Cristoph. Repercussões da formação jurídica na obra teológica de Bèze (tradução inédita de Danilo Chiovatto Serpa, no original: Wirkungen der Juristischen Schulung auf Bezas Theologisches Euvre). In: Théodore de Bèze (1519-1605): Actes du Colloque de Genève (septembre 2005), Travaux d'Humanisme et Renaissance, CDXXIV. Genève: Droz, 2007.

STRÖHL, Henri. O Pensamento da Reforma. São Paulo: ASTE, 1963.

STRAYER, J. As origens medievais do Estado moderno. Lisboa: Gradiva, 1989.

STRAUSS, Leo; CROPSEY, Joseph. Histoire de la Philosophie politique. Paris: Quadrige/PUF, 1994.

VILLEY, Michel. A formação do pensamento jurídico moderno. São Paulo: Martins Fontes, 2005.

WEILL, G. Les théories sur le pouvoir royal em France pendant les guerres de religion. Paris: Hachette, 1892.

WILLIAMS, George Hunstston. La Reforma Radical. Cidade do México: Fondo de Cultura Economica, 1983.

WEITHMAN, Paul. Augustine' s political philosophy. In: KRETZMANN, Norman; STUMP, Eleonore. The Cambridge Companion to Augustine. Cambridge: Cambridge University Press, p. 234-252, 1993.

WITTE JR., John. The Reformation of Rights: Law, religion, and human rights in early modern Calvinism. Cambridge: Cambridge University Press, 2007.

WHITFORD, David Mark. Tyranny and Resistance, The Magdeburg Confession and The Lutheran Tradition. Saint Louis: Concordia Publishing House, 2001.

Luther' s political encounters. In: MCKIM, Donald K. (org.).

The Cambridge Companion to Martin Luther. Cambrige: Cambridge University Press, p. 190, 2007. 